Portland State University

PDXScholar

Fall 12-12-2014

\title{
The Geology and Petrology of Enigmatic Rhyolites at Graveyard and Gordon Buttes, Mount Hood Quadrangle, Oregon
}

\author{
Elizabeth G. Westby \\ Portland State University
}

Follow this and additional works at: https://pdxscholar.library.pdx.edu/open_access_etds

Part of the Volcanology Commons

Let us know how access to this document benefits you.

\section{Recommended Citation}

Westby, Elizabeth G., "The Geology and Petrology of Enigmatic Rhyolites at Graveyard and Gordon Buttes, Mount Hood Quadrangle, Oregon" (2014). Dissertations and Theses. Paper 2063.

https://doi.org/10.15760/etd.2062

This Thesis is brought to you for free and open access. It has been accepted for inclusion in Dissertations and Theses by an authorized administrator of PDXScholar. Please contact us if we can make this document more accessible: pdxscholar@pdx.edu. 
The Geology and Petrology of Enigmatic Rhyolites at Graveyard and Gordon Buttes, Mount Hood Quadrangle, Oregon

by

Elizabeth G. Westby

A thesis submitted in partial fulfillment of the requirements for the degree of

Master of Science

in

Geology

Thesis Committee:

Martin J. Streck, Chair

Nancy A. Price

John Bershaw

Portland State University

2014 


\section{Abstract}

Rhyolite lava flows are found at two dome complexes at Graveyard Butte and Gordon Butte, Mount Hood Quadrangle, Oregon. At Graveyard Butte, the White River has cut a winding canyon $150 \mathrm{~m}$ deep, exposing at its base, a 40-meter-thick outcrop of flow-banded rhyolite $\left(73\right.$ wt. $\left.\% \mathrm{SiO}_{2}, 3.67 \pm 0.01 \mathrm{Ma}\right)$ that laterally extends along the canyon wall for about $1 \mathrm{~km}$. Stratigraphically above the flow-banded rhyolite is locallyerupted iron-rich andesites (lava flows, agglutinate and other pyroclastic rocks as well as clastic debris), a rhyolitic ash-flow tuff (74 wt.\% $\mathrm{SiO}_{2}$ ), and the $2.77 \pm 0.36 \mathrm{Ma}$ tholeiitic basalt lava flows of Juniper Flat (Sherrod and Scott, 1995). Roughly 2 km downstream, a phenocryst-poor, maroon-colored rhyolite $(3.65 \pm 0.01 \mathrm{Ma})$ is visible again, forming steep canyon walls for about $1.6 \mathrm{~km}$. A compositionally similar silicic unit is found $18 \mathrm{~km}$ to the northwest of Graveyard Butte at Gordon Butte. Exposed units along Gordon Butte's Badger Creek (3.64 $\pm 0.03 \mathrm{Ma})$ and the southeastern upper slopes of Gordon Butte include rhyolite flows (69.6-72.1 wt.\% $\left.\mathrm{SiO}_{2}\right)$.

The rhyolite lava flows at Graveyard Butte and Gordon Butte's Badger Creek are nearly chemically indistinguishable and both contrast with the younger rhyolitic ash-flow tuff at Graveyard Butte and lava flows on Gordon Butte's Upper Slopes. The rhyolites of Graveyard Butte and Badger Creek are richer in $\mathrm{Nb}$ and $\mathrm{Zr}(30-40 \mathrm{ppm}$ and 487-530 ppm, respectively) than the younger rhyolitic tuff and Upper Slopes flows (13-19 ppm and 235-364 ppm, respectively) and share characteristics with A-type granitoids. The rhyolite lavas are porphyritic $(\sim 7 \%)$ with the porphyroclasts comprising primarily individual feldspars (250-500 $\mu \mathrm{m}$ in length) with ragged margins, oscillatory zoning and 
less commonly, spongy cores. Other phenocrystic phases include fayalitic olivine, Ferich clinopyroxene, and Fe-Ti oxides.

A-type-like incompatible trace-element-enriched compositions as well as mineralogical indicators suggest rhyolite lava flows at Graveyard Butte and Gordon Butte's Badger Creek are likely generated in an extensional tectonic setting. A possible geotectonic framework for generation of these rhyolite lavas is the northward propagating intra-arc rift of the Oregon Cascades. 


\section{Acknowledgements}

Graveyard Butte is a fascinating area to explore. My thanks go to

Dr. Curt Peterson for "discovering" Graveyard Butte during a kayaking adventure down the White River and to my advisor, Dr. Martin Streck, for his guidance throughout the project.

Family, friends, colleagues and complete strangers have knowingly or unknowingly contributed to the completion of this research. My graduate school cohorts, especially those who did their time in $\mathrm{CH} 49$, contributed to lively discussions, provided practical feedback, support and encouragement. My appreciation also extends to Rick Conrey and Dan Miggins for their intellectual curiosity, interest in research and willingness to share their own experiences. To friends and near-total strangers in Corvallis and Pullman, who opened their houses to Emily Jenkins Hess and me while we were working long and late hours in the labs at WSU and OSU, please accept my heartfelt gratitude. Thanks to the Wasco County Department of Public Works, Bureau of Land Management, and Dog River Orchards for permission to access key areas at Graveyard Butte. A special thanks to the U.S. Geological Survey-Cascades Volcano Observatory for use of their petrology lab.

Funding was provided through research grants from Dr. Martin Streck and a student research grant from the Geological Society of America. 


\section{Table of Contents}

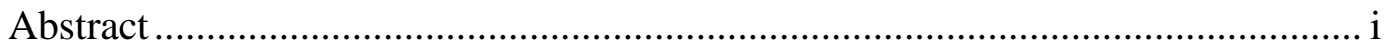

Acknowledgements .................................................................................

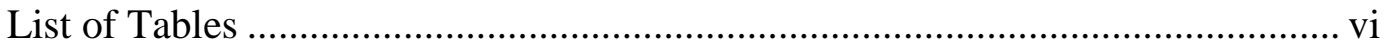

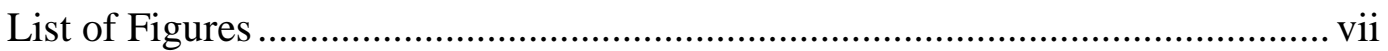

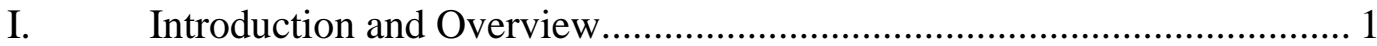

II. Description of the Area ................................................................... 4

III. Geologic History ........................................................................ 10

IV. Stratigraphy and Geologic Map of Graveyard Butte ............................ 14

A. Geologic Map and Description of Rock Units .................................... 14

B. Descriptions of Stratigraphic Sections ............................................... 19

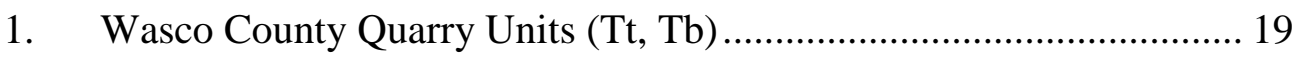

2. Volcaniclastic Deposit Downstream of Bridge $(\mathrm{Tt})$........................ 22

3. Ash-flow Tuff Near Quarry (Qt) ................................................ 25

4. Fluvially-transported Deposits (Qal, Q1) ..................................... 26

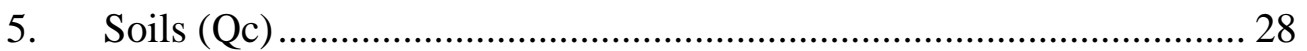

V. Petrography of Graveyard Butte Units ......................................... 30

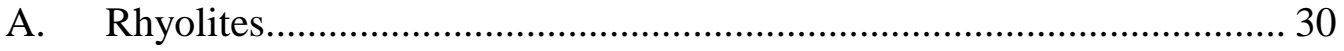

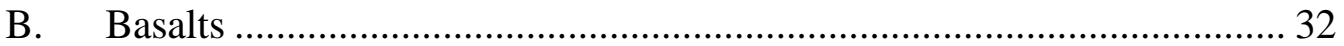




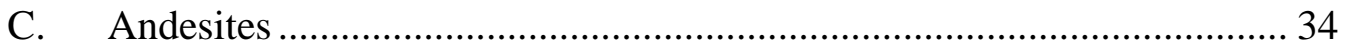

VI. Geochemical Classification and Composition of Graveyard Butte Units with Comparison to Gordon Butte 37

VII. Isotopic Analyses of Rhyolites and Andesite...................................... 46

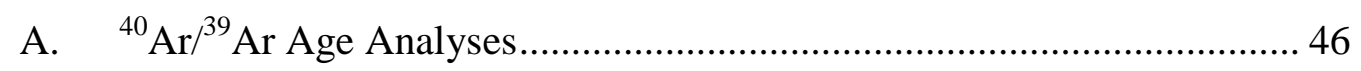

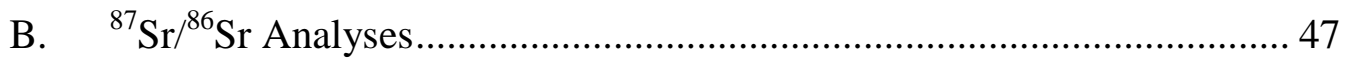

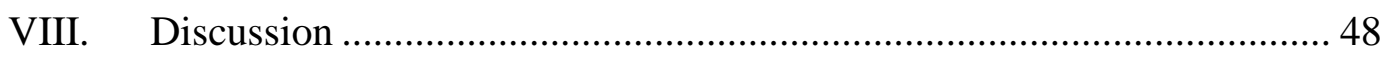

A. Field Evidence for an Endogenous Rhyolitic Dome and Flow at

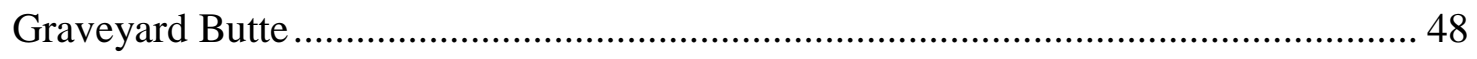

B. Graveyard Butte and Badger Creek are A-Type Rhyolitic Magmas ...... 53

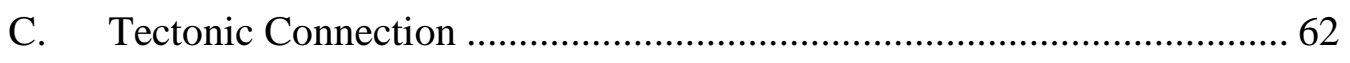

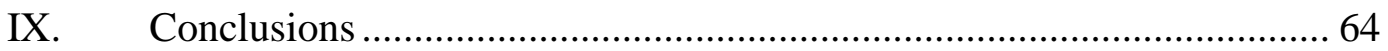

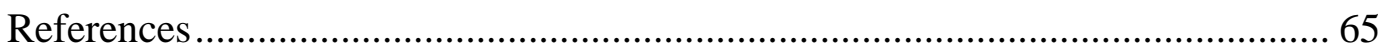

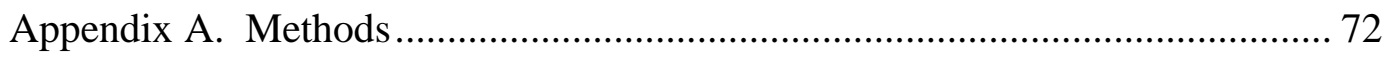

Appendix B. Illustrative Stratigraphic Sections........................................ 75

Appendix C. Energy Dispersive Spectra ….................................................. 77

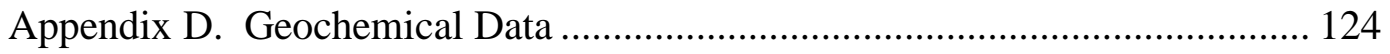

Appendix E. ${ }^{40} \mathrm{Ar} /{ }^{39} \mathrm{Ar}$ Age Results for Graveyard and Gordon Buttes ............ 138 


\section{List of Tables}

Table 1. Description of Map Units at Graveyard Butte. .................................. 17

Table 2. Example of geochemical characteristics for A-type granitoids in samples with $\mathrm{SiO}_{2}$ of $\sim 70$ wt.\% (Bonin, 2007; Eby, 1990) compared to rhyolites at Graveyard and

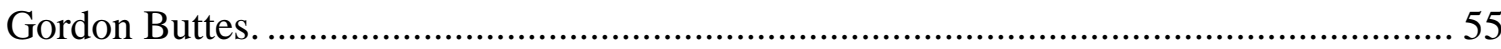




\section{List of Figures}

Figure 1. View to the southwest across the farmland of Smock Prairie with the low profile of Graveyard Butte in the middle distance and the Laughlin Hills in the background. Mount Jefferson is in the upper right. ......................................................

Figure 2. View to the northwest from the south side of Graveyard Butte. The Wasco County quarry is the area in the upper left, located along the White River Crossing Road. The White River is visible in the trees at the bottom center of the image. ............ 2

Figure 3. Map of the area in and around Graveyard Butte. Quaternary faults indicated by dotted lines and folds indicated by solid green lines (U.S. Geological Survey and others, 2006). Basemap from ESRI. Map scale 1:320,000 ............................... 4

Figure 4. Transition zone of conifer forest to pine and oak near the summit of Gordon Butte. View to the west with Mount Hood in the background; a weathered rhyolite outcrop is pictured in the foreground.

Figure 5. View from the White River Crossing bridge looking to the southwest. Channel bar comprised of medium- to dark-gray cobbles is in the bottom center. Local volcaniclastic deposits are visible at water level to mid-way upslope in the center left of

the image. A paleochannel filled with cobbles is exposed in the upper left.

Figure 6. View to the east and flow units on both sides of the White River in the canyon at Graveyard Butte. The stand of pines in the lower left is at one of five sharp bends in the river channel. The Tygh Ridge anticline is in the background, upper left. ... 9

Figure 7. Geologic maps show the distribution and composition of ancestral Cascade arc (Western Cascades) rocks emplaced at (A) 17-8 Ma, and (B) 7-2 Ma, in 
northern Oregon. Bi-modal eruption of basalt and dacite are shown at Graveyard Butte in the 7-2 Ma time period. Modified from du Bray and John (2011).............................. 11

Figure 8. View to the northwest from the south side of Graveyard Butte, with Mount Hood in the center background and Gordon Butte in the far right background. The Wasco County quarry is in the center of the image. The extent of units found in this area is indicated by dotted lines 14

Figure 9. Geologic map of Graveyard Butte, Oregon.................................... 15

Figure 10. (A) Correlation of units from Graveyard Butte geologic map, (B) hypothetical cross-section for A-A', and (C) hypothetical cross section for B-B'....

Figure 11. Stratigraphy of the Wasco County quarry. The upper schematic outlines the seven units visible in the lower image. 20

Figure 12. Schematic diagram and image of sedimentary units downstream of the White River Crossing bridge on the south side of the White River. Height of exposure in image is $\sim 15$ meters.

Figure 13. View to the northeast from the White River Crossing Road and ashflow tuff. Person at left of image (1.7 $\mathrm{m}$ tall for scale) is examining a channel cut filled with rounded cobbles.

Figure 14. (A) Upper image shows wide view of White River Canyon (looking east or downstream); (B) magnified section of image with dashed line and annotation showing the base of a paleochannel with rounded cobbles cutting into volcaniclastic sediment. The White River Crossing bridge is in the bottom center. 
Figure 15. Debris flow in upper left, carved into volcaniclastic sediment. The paleochannel is approximately $5 \mathrm{~m}$ above the modern-day river channel.

Figure 16. Backscatter electron micrograph of sample S6-13, with clinopyroxene and Fe-Ti oxide. 30

Figure 17. Backscatter electron micrograph of sample S6-13, a flow-banded rhyolite, with Na-rich plagioclase, fayalitic olivine, Fe-Ti oxide and zircon. 31

Figure 18. Representative examples of Graveyard Butte rhyolite crystal assemblages: (A) sample WR13 show feldspar with ragged margins (magnification 5x); (B) sample S6-13 clinopyroxene (brown) and plagioclase (magnification 10x); (C) sample X3 crystal clot (magnification 10x); (D) sample X3 includes a mafic enclave (magnification 10x). All images under cross-polarized light.

Figure 19. Sample WR11 as viewed (A) under petrographic microscope with crossed-polarized light, and (B) as an annotated backscatter electron micrograph. 33

Figure 20. Illustrative examples of Graveyard Butte andesites: (A) sample S12-6 (magnification 10x); (B) sample S12-6 (magnification 5x) (C) sample S12-6 vein (magnification 5x); (D) sample V1 (magnification 2.5x). All images under crosspolarized light. 35

Figure 21. Sample V1 includes a rounded melt inclusion, with zoned plagioclase, clinopyroxene and oxides. 36

Figure 22. Map of Gordon Butte rhyolite sample locations at Badger Creek and Upper Slopes. Basemap from ESRI. Map scale is 1:30,000. 
Figure 23. Sample locations for Graveyard Butte include the western canyon, central canyon or quarry and eastern canyon. Basemap from ESRI. Map scale is $1: 30,000$ 38

Figure 24. Classification of 40 geochemical samples from Graveyard Butte (solid symbols) and Gordon Butte (open red squares with cross). The data consists of four basalts, nine andesites, six trachyandesites, and 21 rhyolites. All samples are subalkaline/tholeiitic. Total Alkalis-silica classification after LeBas et al., 1986; alkaline, subalkaline/tholeiitic fields after Cox et al., 1979. 39

Figure 25. (A) Rhyolites show variability in $\mathrm{FeO}_{\mathrm{t}} / \mathrm{MgO}\left(\mathrm{FeO}_{\mathrm{t}}\right.$ is total $\left.\mathrm{Fe}\right)$ compared to andesites and basalts; samples plot almost exclusively in the tholeiitic field (boundaries from LeBas et al., 1986). (B) Rhyolites are high-K, while andesites and basalts (with one exception) are medium-K (suite boundaries from Ewart, 1982).

Figure 26. Comparison of $\mathrm{Zr}$ versus $\mathrm{SiO}_{2}$ by location (symbols as in Figure 24). Two sample locations are distinguished for Gordon Butte (Badger Creek and Upper Slopes) and six for Graveyard Butte (E Canyon, W Canyon, Central Canyon, Quarry, Above Quarry, and Tuff). For the rhyolites, the Badger Creek and most Graveyard Butte samples have higher Zr than the Upper Slopes and Tuff.

Figure 27. Comparison of $\mathrm{Sr}$ versus $\mathrm{SiO}_{2}$ by location. For the rhyolites, the Badger Creek and most Graveyard Butte samples have lower Sr concentrations than the Upper Slopes and Tuff.

Figure 28. Primitive mantle normalized incompatible trace element pattern for rhyolite samples of Graveyard Butte (filled squares) and Gordon Butte (unfilled squares 
with cross). The Graveyard and Badger Creek samples have higher concentrations of LREE and HREE than those from Gordon Butte's Upper Slopes. C1 Chondrite normalizing values from McDonough and Sun (1995).

Figure 29. Primitive mantle normalized incompatible trace element pattern for basalt samples shows enrichment in $\mathrm{Ba}, \mathrm{U}, \mathrm{K}, \mathrm{Pb}$ and $\mathrm{Sr}$. Primitive mantle normalizing values from Sun and McDonough (1989)

Figure 30. Primitive mantle normalized incompatible element pattern for andesite samples shows enrichment in $\mathrm{Ba}, \mathrm{U}, \mathrm{K}, \mathrm{Pb}$ and $\mathrm{Sr}$, with depletions in $\mathrm{Nb}, \mathrm{Ce}, \mathrm{P}$ and $\mathrm{Ti}$. The two samples with distinctly lower values are S6-10U and CC16. Primitive mantle normalizing values from Sun and McDonough (1989).

Figure 31. ${ }^{40} \mathrm{Ar} /{ }^{39} \mathrm{Ar}$ age spectra for (A, B) Graveyard Butte rhyolite, (C) Graveyard Butte andesite and (D) Gordon Butte rhyolite. Ages from the weighted plateau.

Figure 32. The upward rise of the rhyolitic magma (bottom left of image) produced the thrust fault in the overlying andesitic unit. As shown, the andesite of the $\mathrm{A}^{\prime}$ block is thrust over the $\mathrm{A} "$.

Figure 33. The rhyolite to the west of the Wasco County quarry is brecciated (as viewed behind the red carapace) but also includes a segmented, coherent flow (to the far left of image) 50

Figure 34. Examples of unbrecciated, coherent rhyolitic flow in the western canyon: (A) is a flow and doming feature (geochemical sample CC3); and (B) is flowbanded rhyolite 
Figure 35. Deposition and evolution sequence of units at the Wasco County quarry, with focus on changes to Unit 7. The initial position of the volcaniclastic unit is nearly horizontal. The rising rhyolitic magma bends and tilts the volcaniclastic package, with subsequent deposition of volcaniclastic debris down the inclined slope.

Hydrothermal fluids and vapor produce the color gradations. The image to the right is provided for visual reference. 51

Figure 36. Dark-red or maroon is a color tracer for the contact between the rhyolitic intrusion and volcaniclastic debris of the quarry's Unit 7. The light-gray, brecciated rhyolite is visible in the upper right of the image behind the red-maroon carapace, and as the gray-pink surface in the middle left of the image.

Figure 37. Geochemical diagrams demonstrate that Graveyard Butte and Badger Creek rhyolites have greater abundances of HFSE such as (A) Ta and Tb, and (B) Zra are (C) lower in fluid-mobile elements such as $\mathrm{Sr}$, and (D) have a lower Ce concentration, than Graveyard Butte ash-flow Tuff and rhyolites of Gordon Butte's Upper Slopes. ..... 56

Figure 38. Incompatible trace element diagram shows Graveyard Butte and Gordon Butte Badger Creek rhyolites with greater abundances compared to Gordon Butte Upper Slopes rhyolite and Mill Creek Butte, a Western Cascades-era subductiongenerated dacite.

Figure 39. Lavas of Graveyard and Gordon Buttes characterized in (A) using the Fe-index, and (B) the modified alkali-lime index (fields after Frost and Frost, 2008). Rhyolites are ferroan and primarily alkalic-calcic, consistent with A-type granitoid geochemistry (Frost and Frost, 2001). 59 
Figure 40. Comparison of regional rock samples to Graveyard Butte rhyolites and andesites, and Gordon Butte rhyolites, (A) $\mathrm{Nb}$ versus $\mathrm{SiO}_{2}$, and (B) Y versus $\mathrm{Nb}$. Data from Bonnichsen et al., 1994, McClaughry et al., 2009, Fierstein et al., 2011, MacLeod et al., 1995, du Bray and John, 2011, Conrey, unpublished, Johnson, 2011 and Appendix D. Geochemical Data, Table 3, Table 4, Table 5, Table 6, and Table 7)....... 60 Figure 41. Regional map of central and northern Oregon with folds (solid green lines) and faults (dotted lines) (U.S. Geological Survey and others, 2006). Basemap by ESRI. Map scale 1:750,000. 


\section{Introduction and Overview}

Graveyard Butte has a very unremarkable exterior. Its low-profile is covered by pasture grass, small pine and oak, and overshadowed by the nearby folded terrane of Tygh Ridge, Mutton Mountains and Laughlin Hills (Figure 1). On clear, sunny days, Mount Hood and Mount Jefferson come into view, from their positions tucked back behind the foothills of the Cascade Range. Isolated in the middle of the flat to undulating expanse of Smock Prairie and Juniper Flat, it is difficult to discern how Graveyard Butte fits into the geologic landscape.

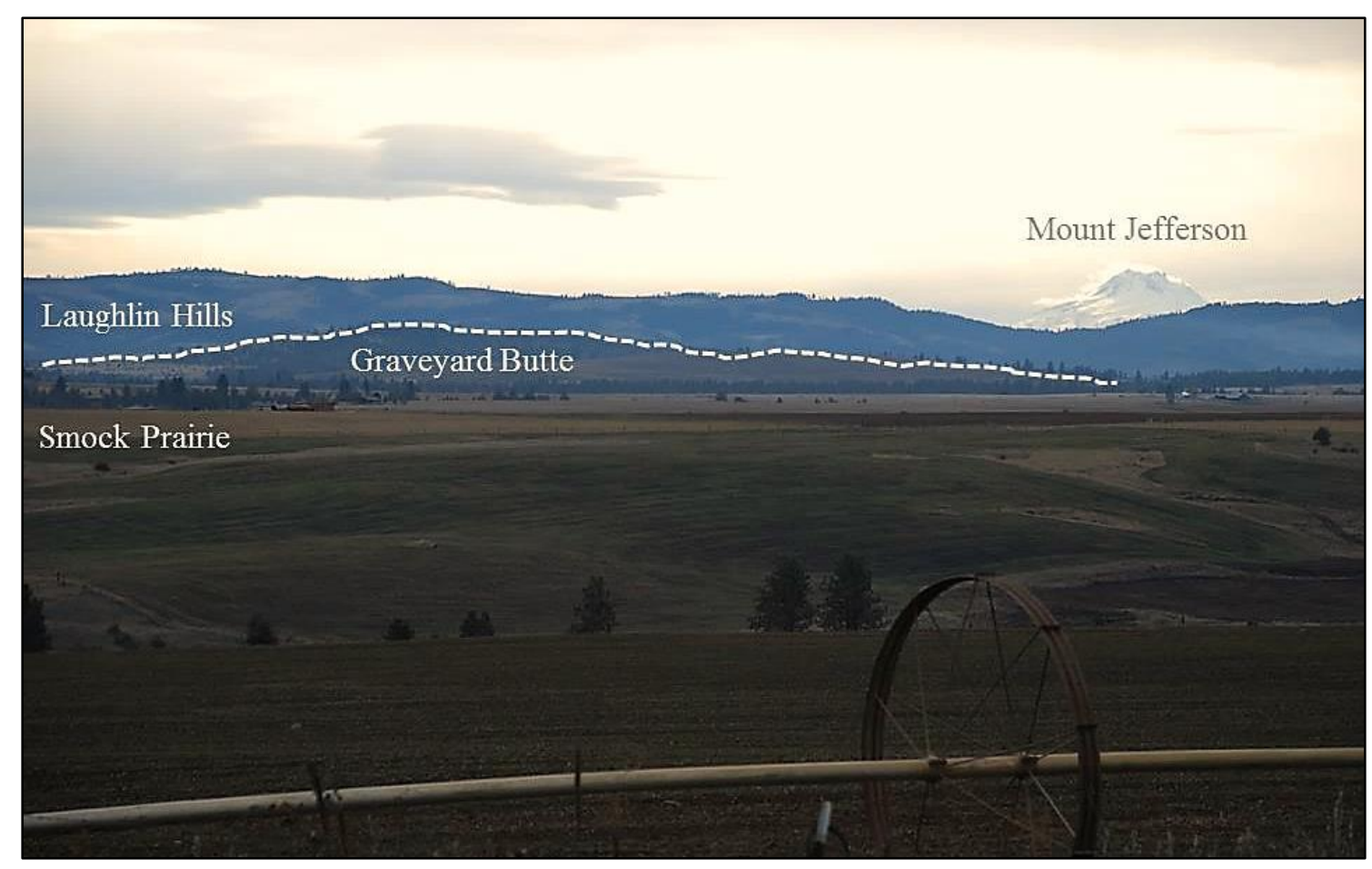

Figure 1. View to the southwest across the farmland of Smock Prairie with the low profile of Graveyard Butte in the middle distance and the Laughlin Hills in the background. Mount Jefferson is in the upper right.

In contrast to its plain cinder cone-like exterior (Sherrod and Scott, 1995), entry into the interior or central portion of Graveyard Butte is richly rewarding (Figure 2). The 
White River has carved a 150-m-deep canyon into volcanic sediments and lava flows, and stranded paleochannels filled with cobbles high above the current water line, all within a compact area of less than $6 \mathrm{~km}^{2}$.

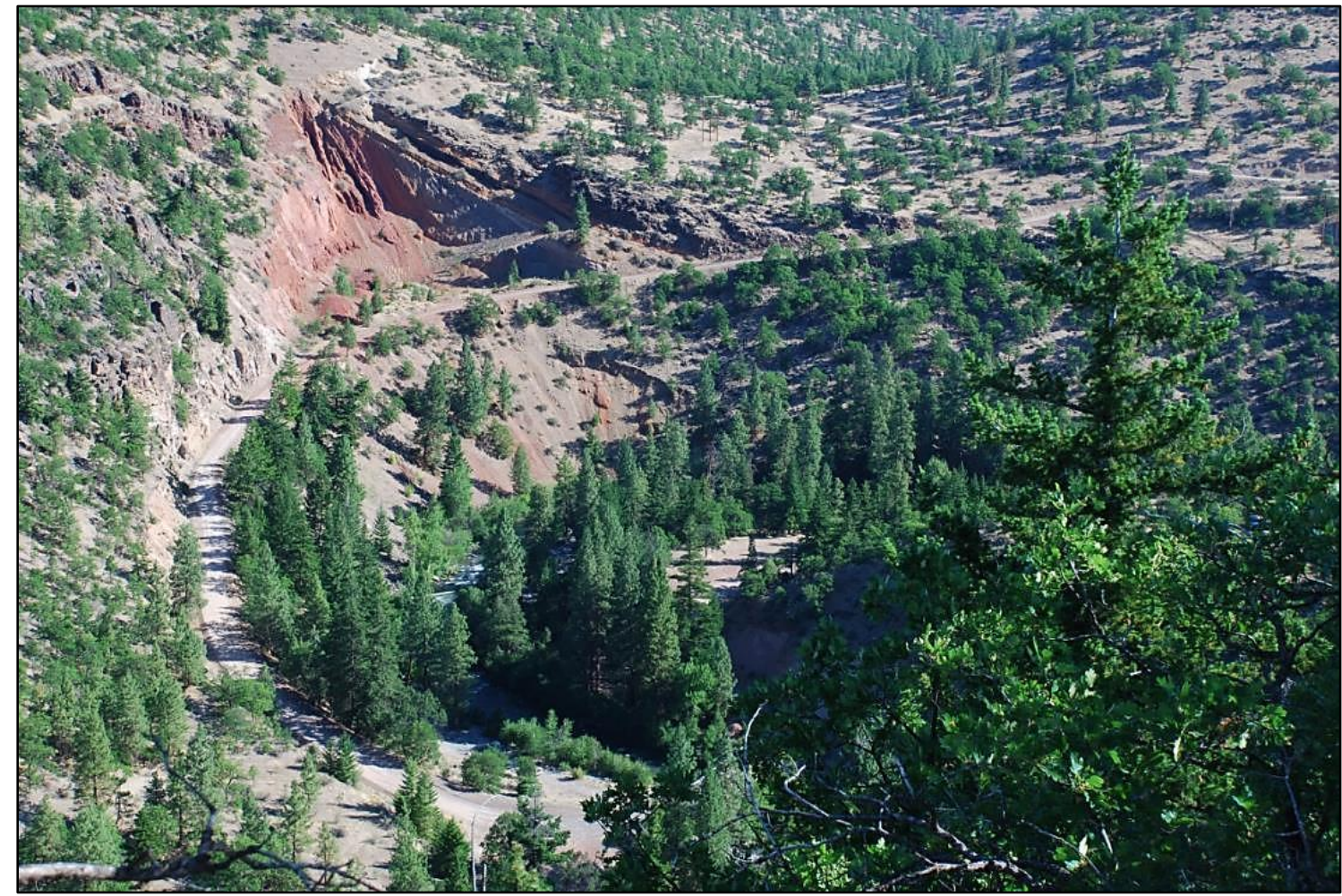

Figure 2. View to the northwest from the south side of Graveyard Butte. The Wasco County quarry is the area in the upper left, located along the White River Crossing Road. The White River is visible in the trees at the bottom center of the image. 
This study focuses on volcanism at Graveyard Butte-mapping the volcanic and sedimentary units inside the White River canyon, and conducting petrographic, geochemical and isotopic age analyses of Graveyard Butte samples. The rhyolite at Graveyard Butte is compared to rhyolite found at Gordon Butte, located 18 kilometers $(\mathrm{km})$ to the west, in order to place the volcanism into a broader regional context. The intent of the research is to distinguish events at Graveyard Butte, investigate the connection between the two buttes, and propose a conceptual geotectonic framework for the evolution of magmas at Graveyard and Gordon Buttes. 


\section{Description of the Area}

Graveyard Butte is located in what is informally known as Tygh Valley, Oregon

(Figure 3).

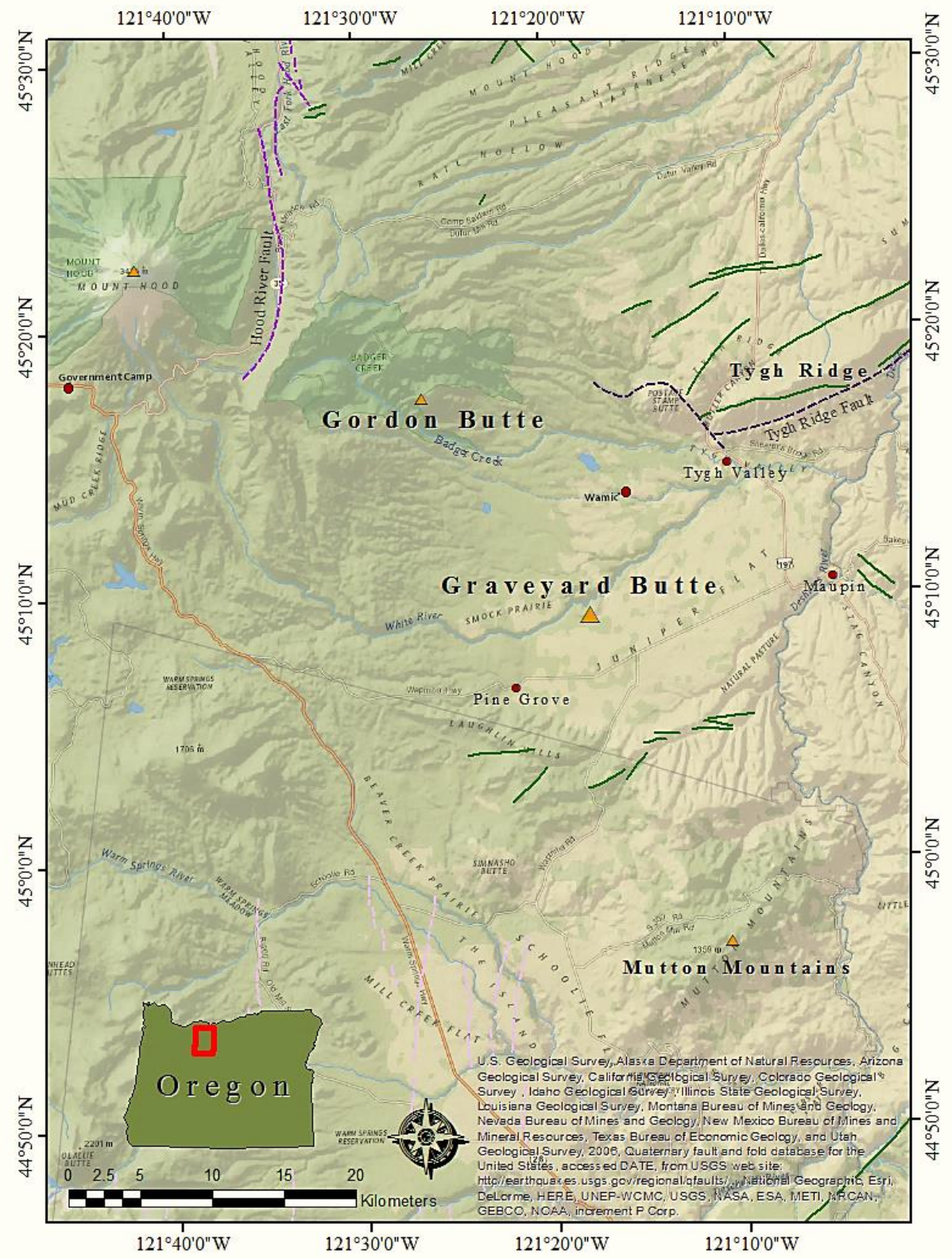

Figure 3. Map of the area in and around Graveyard Butte. Quaternary faults indicated by dotted lines and folds indicated by solid green lines (U.S. Geological Survey and others, 2006). Basemap from ESRI. Map scale 1:320,000. 
The butte is located west of the towns of Maupin and Tygh Valley, near Wamic and Pine Grove. Other nearby landforms are the Tygh Ridge anticline to the northeast, Mutton Mountains to the southeast and Mount Hood to the northwest. Gordon Butte is $\sim 18 \mathrm{~km}$ northwest of Graveyard Butte; Badger Creek runs along the southern margin of Gordon Butte.

The buttes are located in a transition zone between western and eastern Oregon climates. Traveling south on Highway 26 from Government Camp, dense stands of Douglas fir give way to stunted Ponderosa pine and white oak (Figure 4). Mount Hood's lush montane ecology, supported by 91 centimeters $(\mathrm{cm})$ of annual rainfall (National Oceanic and Atmospheric Administration, 2014) and several meters of snow, becomes oak, pine, sagebrush and grass covering the flat prairies around the towns of Pine Grove, Wamic and Tygh Valley. Mount Hood, at an elevation of 3,426 meters (m), creates a rain shadow on its east side, challenging local farmers and ranchers with only $45 \mathrm{~cm}$ of annual precipitation (Soil Survey Staff, undated). 


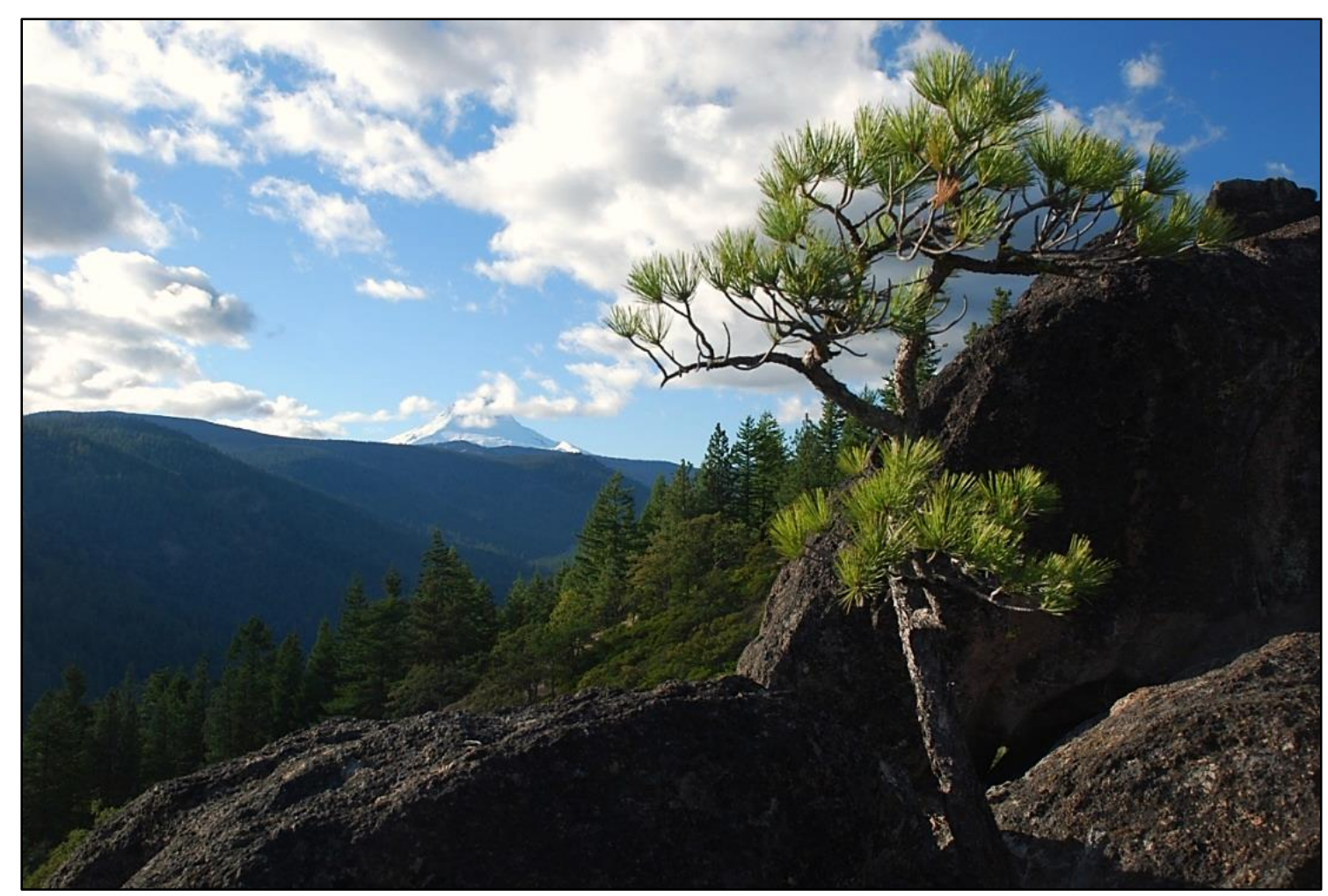

Figure 4. Transition zone of conifer forest to pine and oak near the summit of Gordon Butte. View to the west with Mount Hood in the background; a weathered rhyolite outcrop is pictured in the foreground.

At the turn-off for the White River Crossing (near Pine Grove), the road becomes a gravel wash-board, long used by local residents. Elevated to county road status in 1913 (Marty Matherly, Public Works Director, Wasco County, personal communication, January 27, 2014), the White River Crossing Road bisects open pasture, where loess, ash and silt form a thin layer over rounded mafic cobbles. The cobbles are exposed only in knee-deep gullies where short-duration, intense rains have winnowed finer sediments. From the road, the view forward is nondescript. Although at an elevation of $707 \mathrm{~m}$ above sea level (ASL), the rounded profile of Graveyard Butte rises barely $90 \mathrm{~m}$ above the moderately undulating Smock Prairie and Juniper Flat (see Figure 1). 
At the highest point on the south side of Graveyard Butte, is a small fenced-off cemetery for local families Claymier, Hix, Laughlin, Magill, McCorkle, McCubbins, and Smith. Many of the families traveled west by ox team from Missouri and Ohio in the mid-1850s, completing their journey along the local section of the Barlow Trail. They acquired 160 acre land grants and settled in the area to farm and raise livestock (Shaver et al., 1905). Descendants remain in the area and features such as the Laughlin Hills, McCubbins Gulch and many of the local roads bear the names of these early pioneers. The area at and around Graveyard Butte today, is a combination of private ownership parcels used for dry-land agriculture, orchards and animal grazing, with land along the White River overseen by the Bureau of Land Management as part of the White River Wild and Scenic Area.

The southern entrance to Graveyard Butte's White River canyon first passes by an unofficial landfill, with its buck-shot washing machine, plastic detritus, and occasional animal carcass. The second, more appealing sight is inside the 150-m-deep White River canyon. The southern promontory offers a view to the west toward massive terraced basalt flows incised by the White River. Originating at the terminus of the White River Glacier on the east side of Mount Hood, the White River flows southeasterly away from the volcano. In its upper reaches, the river drops $250 \mathrm{~m}$ per $\mathrm{km}$ over its first $6 \mathrm{~km}$ before turning directly east at Smock Prairie. In the middle section where Graveyard Butte is located, the river drops an average of $30 \mathrm{~m}$ per km (Figure 5). Once the river passes the town of Tygh Valley, the lower reach drops about $15 \mathrm{~m}$ per $\mathrm{km}$. It then joins the 
Deschutes River upstream of Sherar's Falls, north of Maupin, at River Mile 47.5 (76.4 $\mathrm{km}$ ), at an elevation of $240 \mathrm{~m}$ (Wasco County Comprehensive Plan, 1983).

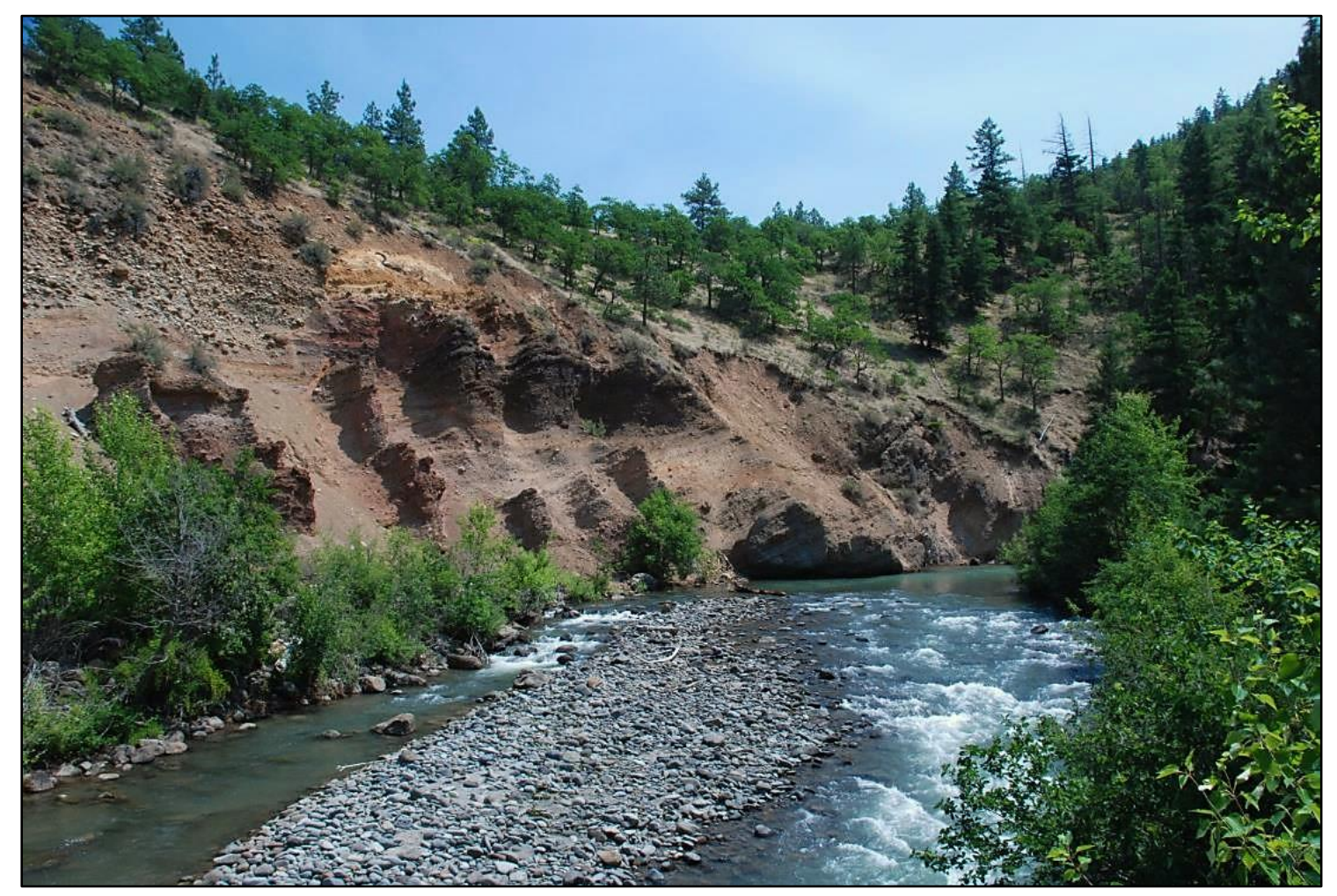

Figure 5. View from the White River Crossing bridge looking to the southwest, upstream. Channel bar comprised of medium- to dark-gray cobbles is in the bottom center. Local volcaniclastic deposits are visible at water level to mid-way upslope in the center left of the image. A paleochannel filled with cobbles is exposed in the upper left.

From this same viewpoint looking north, are the rainbow colors of heat- and fluidaltered volcaniclastic debris (see Figure 2). The sediments were once quarried by the Wasco County Department of Public Works until the conclusion of mining activities in the 1950s (Marty Matherly, Public Works Director, Wasco County, personal communication, January 27, 2014); the county's no trespassing sign remains for target practice. 
The view farthest east (Figure 6) is to warped lava flows and the entrance to a narrow 120-m-high canyon. From there, the White River emerges from its geologic meander of Graveyard Butte, through the Tygh Valley, to eventually join the Deschutes River.

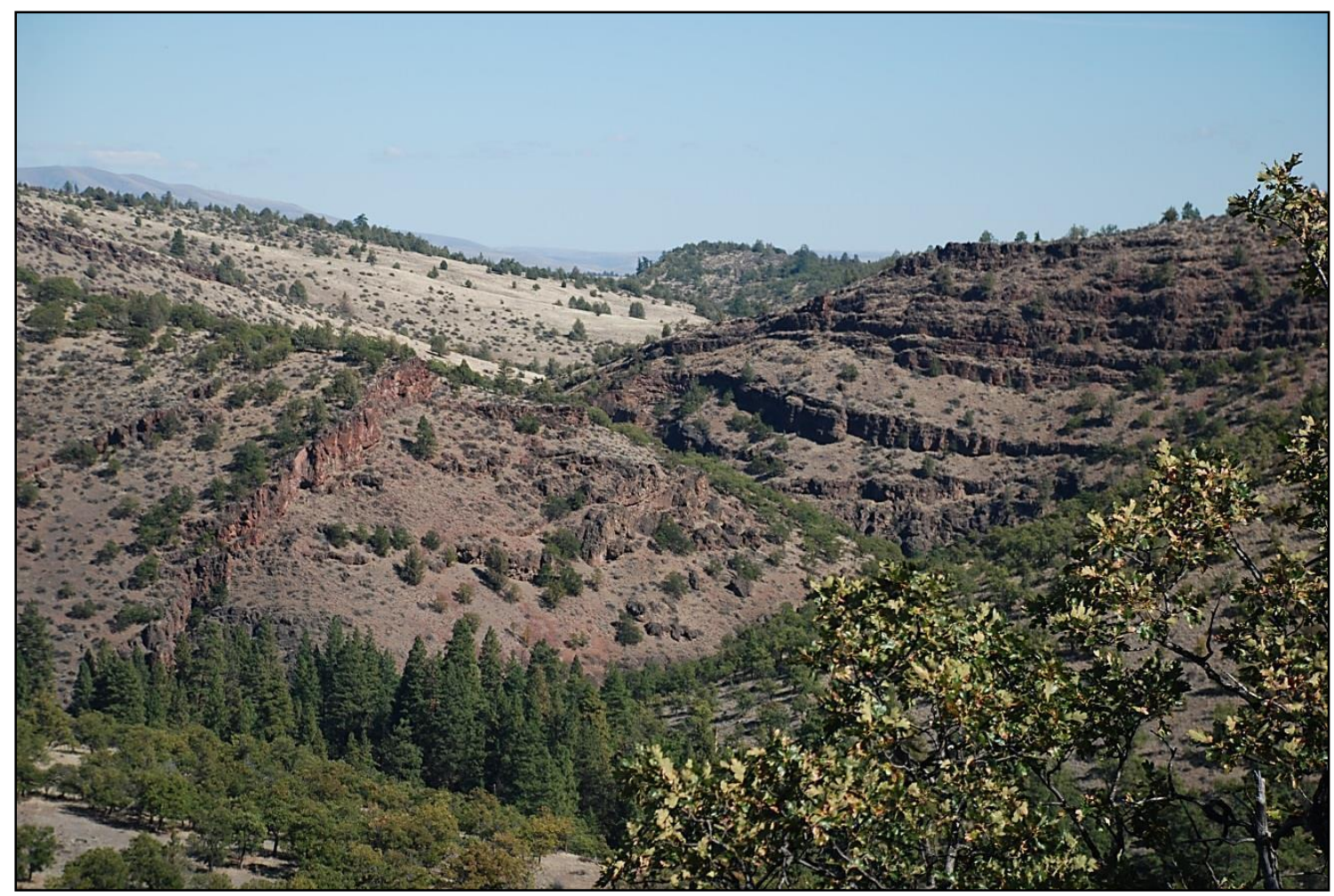

Figure 6. View to the east and flow units on both sides of the White River in the canyon at Graveyard Butte. The stand of pines in the lower left is at one of five sharp bends in the river channel. The Tygh Ridge anticline is in the background, upper left.

The semi-arid climate, sparse vegetation and limited human interaction with the landscape cater to geologists. Outcrop is thin to massive, completely exposed or very nearly buried. Within the confines of Graveyard Butte are epiclastic and volcaniclastic deposits, andesite, rhyolite and basalt flows, that, collectively, represent an important part of the geologic record of this area. 


\section{Geologic History}

Although not locally exposed, Graveyard Butte is underlain by the volcanic, volcaniclastic and sedimentary rocks of the Eocene Clarno Formation and the lateEocene to early-Miocene John Day Formation (Beebee et al., 2002; Johnson, 2011; McClaughry et al., 2009; Smith, 1986).

Some of the earliest local high standing landforms may well have been the Mutton Mountains. Located to the south of Graveyard Butte, volcanism 28-29 Ma produced this rhyolitic dome complex (Johnson, 2011). Around 15.5 Ma, Columbia River Flood Basalts flowed into the Tygh Valley, lapping onto the flanks of the Mutton Mountains (Johnson, 2011). Compression associated with tectonic plate rotation produced folds at Tygh Ridge and Mutton Mountains and deformed the Columbia River Basalts (Beebee et al., 2002; Hildreth et al., 2012; Smith, 1986); the most active period of folding is estimated to have occurred between 8.4-4.5 Ma (Johnson, 2011).

Sitting between the steeply dipping forelimb of the Tygh Ridge anticline to the north and the shallowly-dipping, broad backlimb of the Mutton Mountains anticline to the south, the Tygh Valley syncline is the local depositional basin for the volcaniclastic sediments of the middle-Miocene to Pliocene Tygh Valley Formation. The Tygh Valley Formation consists of weakly cemented basaltic, andesitic and pumiceous sandstone and conglomerate; tuffaceous siltstone and sandstone; tuff; pumice lapilli tuff; tuff breccia; agglomerate; and 1- to 20-m-thick lahar deposits (Farooqui et al., 1981). The Formation is coeval with the Deschutes Formation and part of the larger Dalles Group (Beebee $e t$ 
al., 2002; Farooqui et al., 1981). The Dalles Group extends along the eastern margin of the Cascade Range from the Madras Basin in the south to the Columbia River in the north. The Dalles Group consists of five mid-Miocene to Pliocene age formations that overlay Columbia River Basalts (Farooqui et al., 1981).

The primary source of Tygh Valley Formation sediments is to the west. The Cascade Range is a subduction-created volcanic arc that extends from northern California to southern British Columbia. Eruptions along various segments of the ancestral Cascades (also called the Western Cascades) began about $45 \mathrm{Ma}$, with a period of relative quiescence in northern Oregon until $17 \mathrm{Ma}$ (du Bray and John, 2011). From 17-8 Ma, eruptions to the north and west of Graveyard and Gordon Buttes consisted of andesite (Figure 7(A)) transitioning to basalt with bimodal (basalt/dacite) association at Graveyard Butte during the 7-2 Ma time period (Figure 7(B)) (du Bray and John, 2011).

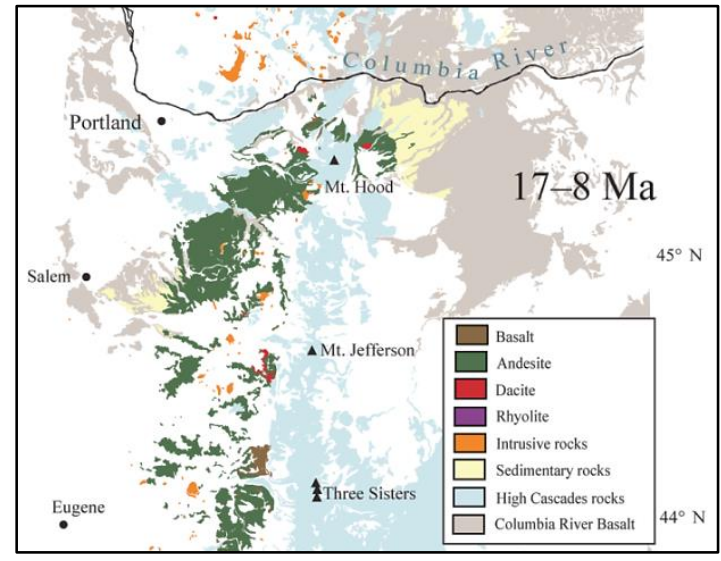

(A)

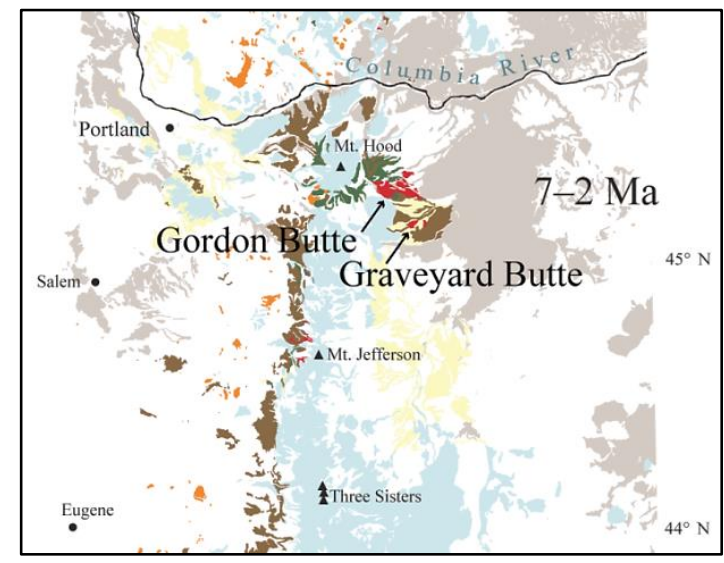

(B)

Figure 7. Geologic maps show the distribution and composition of ancestral Cascade arc (Western Cascades) rocks emplaced at (A) 17-8 Ma, and (B) 7-2 Ma, in northern Oregon. Bimodal eruption of basalt and dacite are shown at Graveyard Butte in the 7-2 Ma time period. Modified from du Bray and John (2011). 
From 5 to $3.5 \mathrm{Ma}$, the geologic record shows evidence for uplift of the Western Cascades (Sherrod and Scott, 1995). Cheney and Hayman (2007) studied deformation of gravels west of Ellensburg, Washington, to conclude that major uplift occurred around 4 Ma. Locally, to the east of Graveyard and Gordon Buttes the broad Deschutes River switched from a mostly aggrading to mostly degrading channel after $4 \mathrm{Ma}$ in response to uplift (Beebee et al., 2002). Moreover, the rise of the Cascades led to creation of a rain shadow, supported by work on fossil floras east of the current Cascades axis. Mustoe and Leopold (2014) concur that the Cascade Range was undergoing major uplift around $4 \mathrm{Ma}$ based on the shift of plant communities in Idaho from a summer-wet and winter-mild climate, to semi-arid, after 3.4 Ma.

Tectonic plate rotation caused north-south compression to produce local and regional folding at Tygh Ridge and Mutton Mountains. The rotation also created eastwest horizontal extension (Hildreth et al., 2012; Wells et al., 1998). As a result, the Pliocene Cascade volcanic platform sank by as much as $1.2 \mathrm{~km}$ in the central part of the Cascade Range between about 5 and $4 \mathrm{Ma}$, and a north-trending graben $30 \mathrm{~km}$ wide and $50 \mathrm{~km}$ long developed along the Green Ridge fault (Beebee et al., 2002; Sherrod and Smith, 2000). The exact location of the northern-most extent of this rift is unknown but is assumed to have propagated northward beyond Mount Jefferson to join the Hood River fault in northern Oregon (Hildreth et al., 2012). The narrow Hood River fault is a northnorthwest-striking fault zone 1 to $3 \mathrm{~km}$ wide formed by an en echelon succession of normal faults that run to the Columbia River. Faulting occurred in late Pliocene or early 
Quaternary time (Sherrod and Smith, 2000), cutting lavas as young as 2.9 Ma (Conrey et al., 1996) (see Figure 3).

To the northwest of Graveyard Butte is Mount Hood, a stratovolcano of the High Cascades, with a modern edifice less than 500,000 years old (Scott et al., 1997). This High Cascades volcano sits upon the remnants of earlier eruptive centers, such as the Sandy Glacier Volcano ( 1.3 Ma); more than 45 peripheral volcanoes of Quaternary and Tertiary age surround Mount Hood on all sides (Hildreth, 2007). Over its eruptive history, Mount Hood has produced a consistent composition of andesitic domes and lava flows that has trended over the last 15,000 years to a more dacitic composition (Koleszar et al., 2012). No widespread tephra fall units are known to have erupted from Mount Hood (Hildreth, 2007), although neighboring volcanoes to the north (Mount St. Helens) and the south (Mount Jefferson, Three Sisters, and Crater Lake) have had significant explosive eruptions (Conrey et al., 2002; Koleszar et al., 2012). 


\section{Stratigraphy and Geologic Map of Graveyard Butte}

Units at Graveyard Butte include rhyolite, andesite and basalt, plus thin to massive volcaniclastic and sedimentary deposits (Figure 8, Table 1).

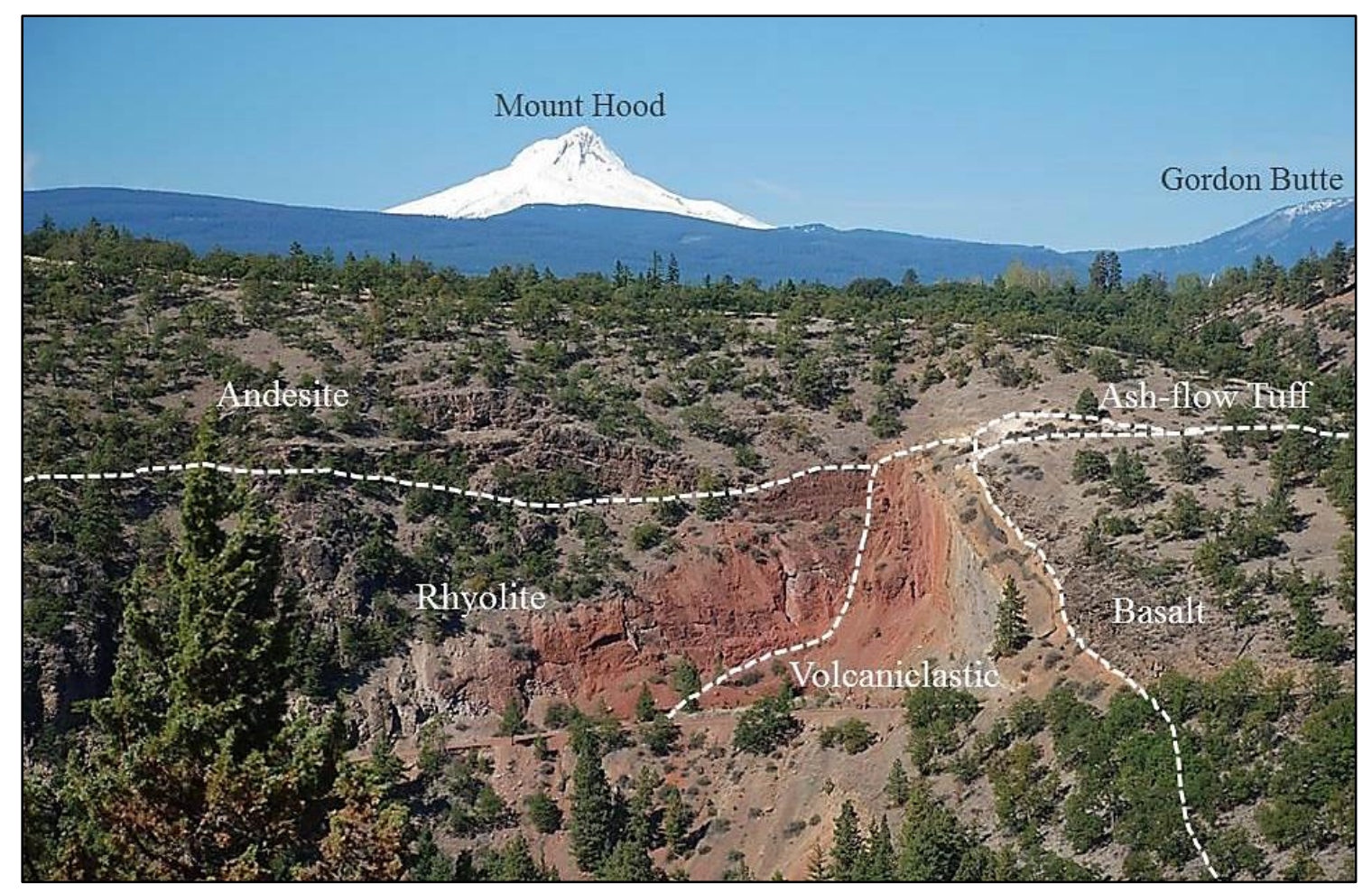

Figure 8. View to the northwest from the south side of Graveyard Butte, with Mount Hood in the center background and Gordon Butte in the far right background. The Wasco County quarry is in the center of the image. The extent of units found in this area is indicated by dotted lines.

\section{A. Geologic Map and Description of Rock Units}

The geologic map of Graveyard Butte is provided in Figure 9, with polygons defining the lateral extent of the surficial units mapped for this study. Figure 10 includes a correlation of units and two hypothetical cross-section, $\mathrm{A}-\mathrm{A}^{\prime}$ and $\mathrm{B}-\mathrm{B}^{\prime}$, with the locations indicated on the geologic map. The description of rock units is provided in Table 1. 


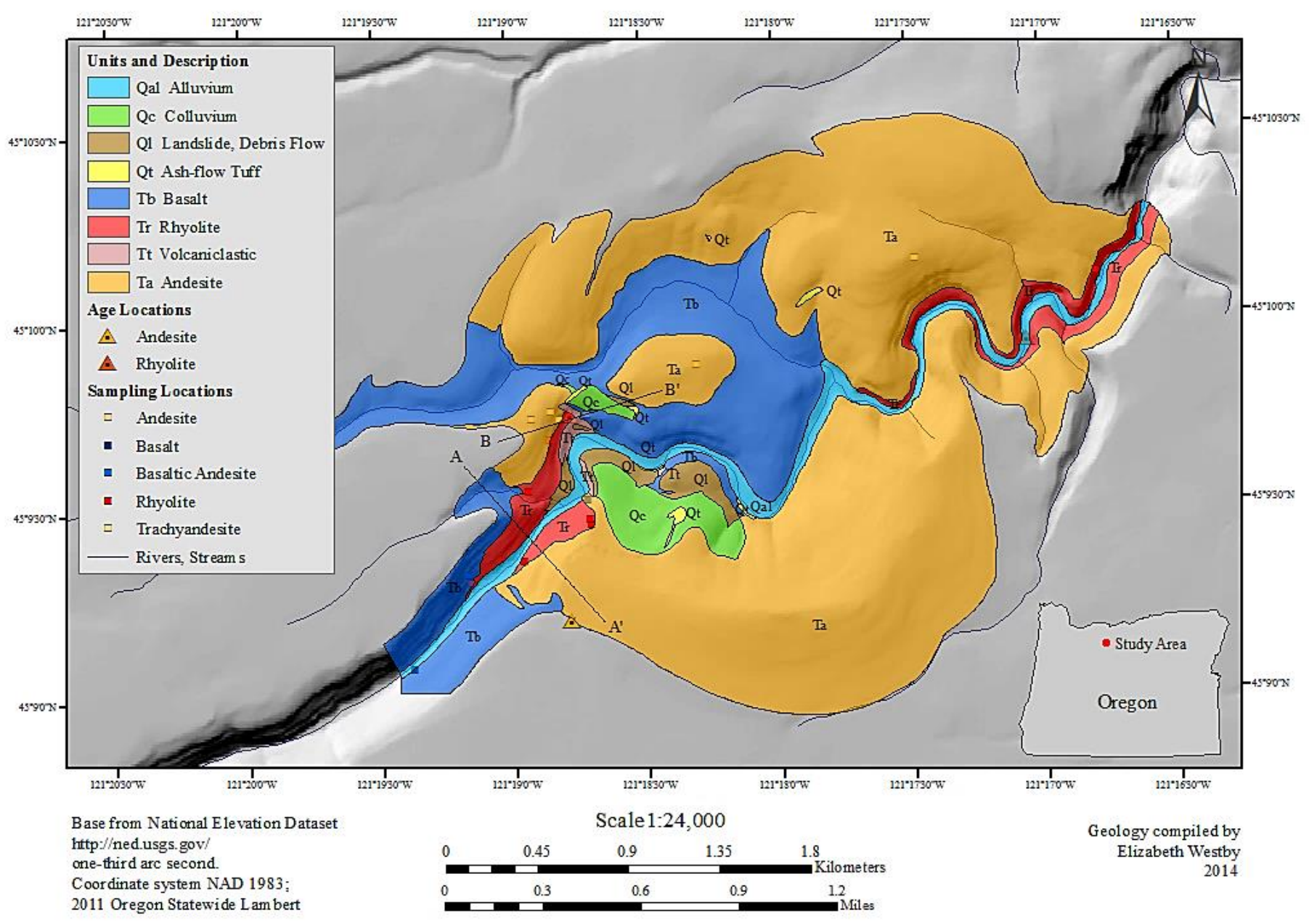

Geologic Map of Graveyard Butte, Oregon

Figure 9. Geologic map of Graveyard Butte, Oregon. 
Correlation of Map Units
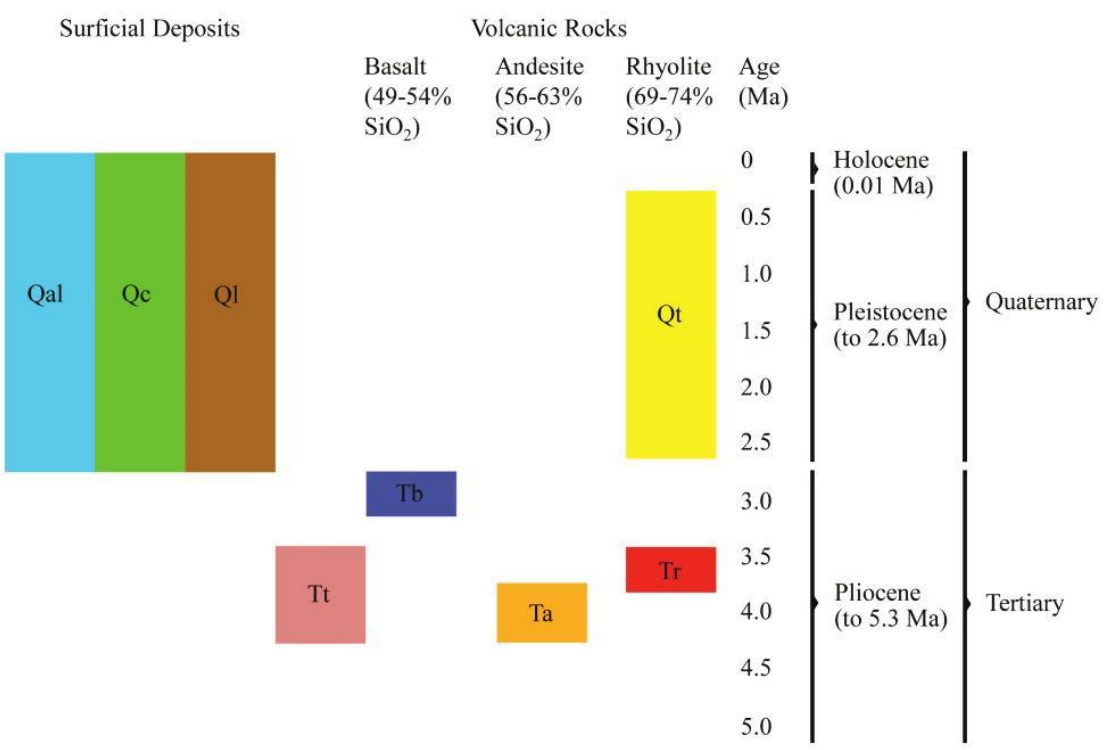

(A)

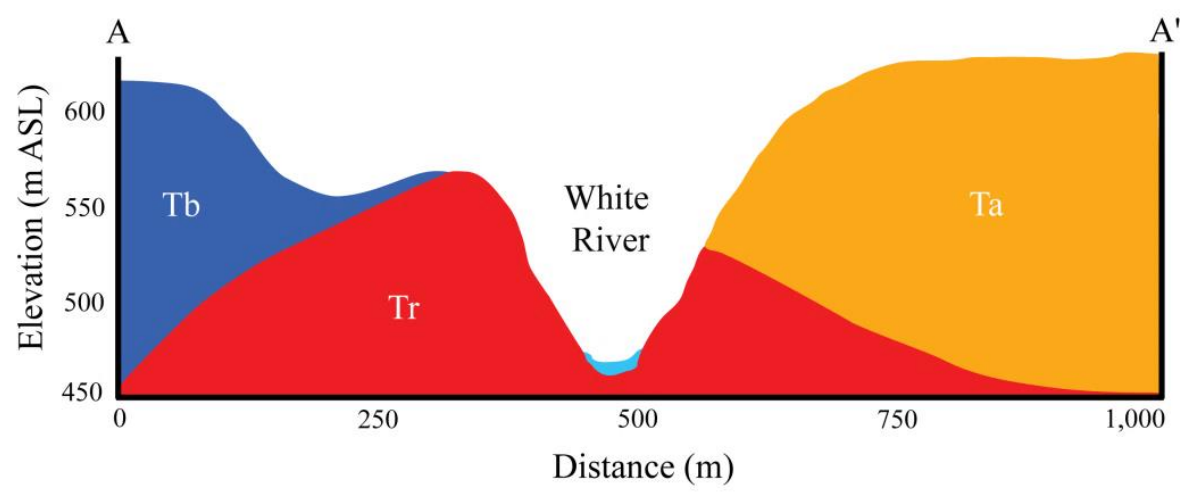

(B)

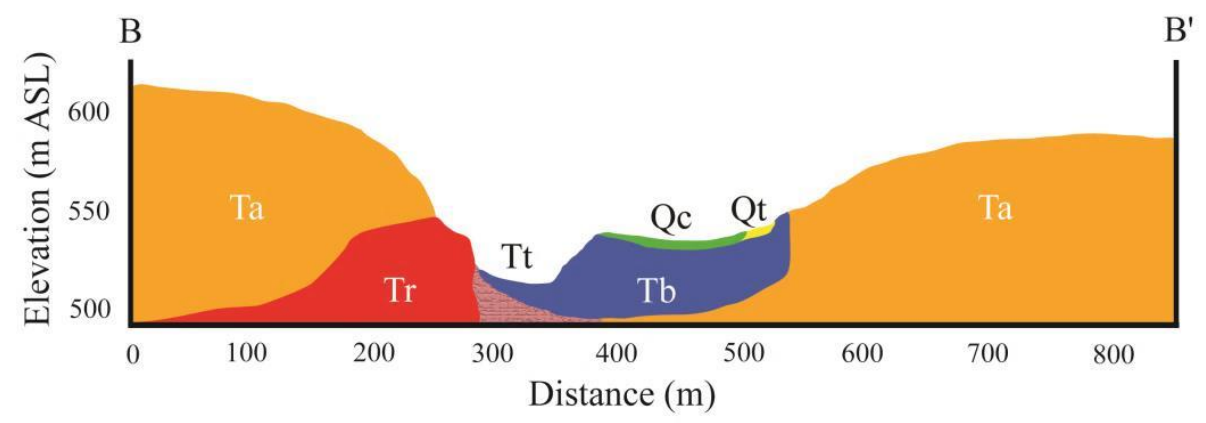

(C)

Figure 10. (A) Correlation of units from Graveyard Butte geologic map, (B) hypothetical crosssection for $\mathrm{A}-\mathrm{A}^{\prime}$, and $(\mathrm{C})$ hypothetical cross section for $\mathrm{B}-\mathrm{B}$ '. 
Table 1. Description of Map Units at Graveyard Butte.

\section{Unit Description}

Qal Alluvium (Holocene, Pleistocene)

Unconsolidated fluvial deposits of volcanic origin, ranging from clay- and sandsized to unconsolidated gravels, cobbles and boulders (gray). Includes low-relief natural levees and areas of sand and silt overwash adjacent to the White River channel. Unit likely originates on the slopes of Mount Hood at the base of the White River glacier as outwash, debris-flows and the erosional re-working of volcaniclastic deposits, or as gravels and boulders of eroded local lava flows such as the Juniper Flat basalt flow.

Qc Colluvium (Holocene, Pleistocene)

Fine-grained loess and ash forming thin soils.

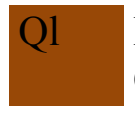

Landslide, Debris Flow (Holocene, Pleistocene)

Channelized flow deposits of unconsolidated, poorly sorted, rounded to subrounded pebbles and cobbles in a sandy matrix. Also includes massively-bedded debris flow at the base of the south side of the White River canyon along the White River channel.

Qt Ash-flow Tuff (Pleistocene) Non-welded ash-rich pyroclastic flow deposit with $\sim 5 \%$ tan-colored, oblate, crystal-rich pumices, $1-15 \mathrm{~cm}$ on longest axis, often with stretched vesicle channels, and $\sim 2 \%$ gray subangular dense lithic fragments $1-2 \mathrm{~cm}$.

\section{Basalt (Pliocene)}

Basalt flows of Juniper Flat with an age of $2.77 \pm 0.36 \mathrm{Ma}$ (Sherrod and Scott, 1995). Color is medium gray, forming lobes $2-40 \mathrm{~m}$ thick with rubbly tops and bottoms and a solid center; often vesiculated in the upper part of the lobes. Identifiable by plagioclase laths to $3 \mathrm{~mm}$ and sparse olivine. Talus forms aprons below steep cliffs, either unvegetated or capable of supporting vegetation if unit includes colluvium. Basalt covers areas adjacent to Graveyard Butte and is channelized into the White River canyon. $\mathrm{SiO}_{2}$ ranges from $49-50$ wt.\% (see Appendix D. Geochemical Data, Table 3). 
Table 1. Description of Map Units at Graveyard Butte.

Unit Description

Rhyolite (Pliocene)

Rhyolite dome and lava flows in southwestern portion of canyon with an ${ }^{40} \mathrm{Ar} /{ }^{39}$ Ar whole rock age of 3.67 $\pm 0.01 \mathrm{Ma}$. Outcrop consists of coherent blocks with fractured and weathered talus apron. Can be flow-banded. Outcrop in northeastern portion of map is massive, commonly microcrystalline and phenocryst-poor, with an ${ }^{40} \mathrm{Ar} /{ }^{39}$ Ar whole rock age of 3.65 $\pm 0.01 \mathrm{Ma} . \mathrm{SiO}_{2}$ ranges from 69-73 wt.\% for both areas (see Appendix D. Geochemical Data, Table 3, Table 4, and Table 5; Appendix E. ${ }^{40} \mathrm{Ar} /{ }^{39} \mathrm{Ar}$ Age Results for Graveyard and Gordon Buttes, Table 8).

Tt Volcaniclastic (Pliocene)

Poorly to moderately indurated volcaniclastic deposits of ash $(62-350 \mu \mathrm{m})$ and small $(\sim 1 \mathrm{~mm})$ pumice and scoria (sometimes pastel pink and gray, black or red). Large scoria to $15 \mathrm{~cm}$ in length, with black or yellow coats over black centers. Some crystal-rich, subangular lithics to $20 \mathrm{~cm}$. Brick-red agglutinate. Beds are thin to massive.

\section{Ta Andesite (Pliocene)}

Andesitic lava flows with an ${ }^{40} \mathrm{Ar} /{ }^{39} \mathrm{Ar}$ whole rock age of $3.86 \pm 0.07 \mathrm{Ma}$. Flows in the western portion of the canyon are coherent, brick red and black with sparse phenocrysts, and can include medium-gray lithics. Agglutinate and scoria on southern side of canyon. In eastern portion of canyon, flows are platy. $\mathrm{SiO}_{2}$ ranges from 56-62 wt.\% (see Appendix D. Geochemical Data, Table 3, Table 4, and Table 5; Appendix E. ${ }^{40} \mathrm{Ar}{ }^{39} \mathrm{Ar}$ Age Results for Graveyard and Gordon Buttes, Table 8). 


\section{B. Descriptions of Stratigraphic Sections}

Units within the White River canyon include lava flows and at least four distinctive volcaniclastic or sedimentary deposits - one at the Wasco County quarry, two in exposures along the White River Crossing Road, and one downstream of the White River Crossing bridge.

\section{Wasco County Quarry Units (Tt, Tb)}

The most visually dramatic depositional site is at the former Wasco County quarry $\left(45.162514^{\circ},-121.3119429^{\circ}\right)$ (Figure 11; see also Appendix B. Illustrative Stratigraphic Sections). The uppermost unit (Unit 1) consists of a plagioclase-rich basalt lava flow with about four subunits, each approximately $2 \mathrm{~m}$ thick. The layers have solid or vesiculated centers (vesicles are 1 millimeter $(\mathrm{mm})$ to $3 \mathrm{~cm}$ ) and frequently, rubbly flow tops and bottoms. 

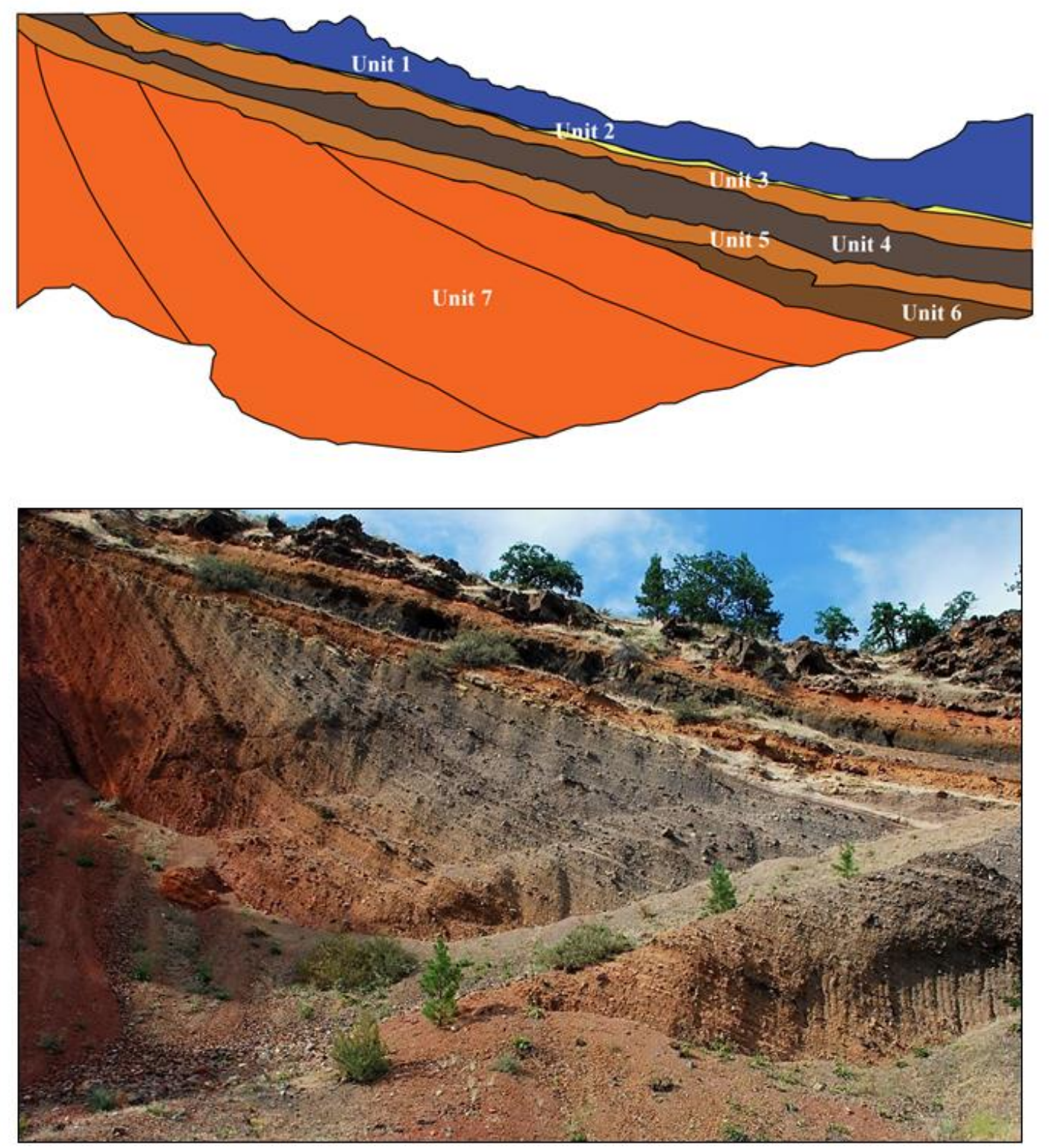

Figure 11. Stratigraphy of the Wasco County quarry. The upper schematic outlines the seven units visible in the lower image.

Beneath the basalt is a thin bed of sand-sized grains with minor lithics (Unit 2). A distinguishing feature of Unit 3 is its brick-red color. The unit consists of ash ( $177-200$ micrometers $(\mu \mathrm{m}))$, black glassy fragments and scoria, along with angular clasts $5-20 \mathrm{~cm}$ 
of gray or red lava. The unit has gradational contacts with upper and lower beds and coarsens upward to a layer of angular lithics before fining upward to the next contact. Unit 4 is a black, structure-less bed of sand-sized $(125-350 \mu \mathrm{m})$ glassy, sub-rounded grains of andesitic composition (see Appendix D. Geochemical Data, Table 4, sample X9). Unit 5 is similar to Unit 3 in its brick-red color but the ashy matrix is finer $(\sim 88-125$ $\mu \mathrm{m})$ with smaller, similarly-sized angular clasts $(4-15 \mathrm{~cm})$ and scoria. Clasts in the upper portion of the unit are more rounded and include black, glassy fragments. The unit is normally sorted and has a sharp contact with the lower unit. Unit 6 is fine, angular ash and lapilli. Bedding consists of scoriaceous material, glassy fragments and subrounded clasts of no more than $1 \mathrm{~cm}$; the unit pinches out upslope and thickens downslope.

Unit 7 is a massive, crudely stratified bed of volcaniclastic debris with an angular unconformity to the strata above. Most distinctive is the gradational color from maroon to brick-red, orange, yellow, tan and gray, with a change in orientation from near vertical to dipping at a shallower angle. From a distance, the unit appears to have crude wavy bedding, marked by large scoria (black with yellow coats) although the layering is not pronounced at close distance. The finest dry-sieved particles (less than $0.063 \mathrm{~mm}$ ) comprise glass shards and bubble walls, along with subhedral translucent yellow, white and dark brown minerals. Subrounded yellow pumices are included in size fractions of $0.250 \mathrm{~mm}$ and greater. At $0.5 \mathrm{~mm}$ and greater, pumices are yellow, brown, brown-green and red [scoria]. Subangular lithics are salmon-colored, gray and white, and maroon. Scoria is found in size increments from $4 \mathrm{~mm}$ to a few as large as $15 \mathrm{~cm}$. 
The base of Unit 7 is not exposed. This part of the site has been re-worked by quarry activities and the building of the White River Crossing Road. Across the road, continuing down the steep slope toward the river, rounded lenticular mounds (less than $1.5 \mathrm{~m}$ high) of brick-red, poorly indurated lithics and red scoria punctuate a slope of grasses and small pines. No solid outcrop was found on the lower slope below the road; the slope is being undercut by the White River.

\section{Volcaniclastic Deposit Downstream of Bridge (Tt)}

Downstream of the White River Crossing bridge, on the south side of the river $\left(45.160097^{\circ},-121.3073957^{\circ}\right)$, there is an exemplary exposure consisting of tuff and reworked volcaniclastic material (Figure 12; see also Appendix B. Illustrative Stratigraphic Sections). 

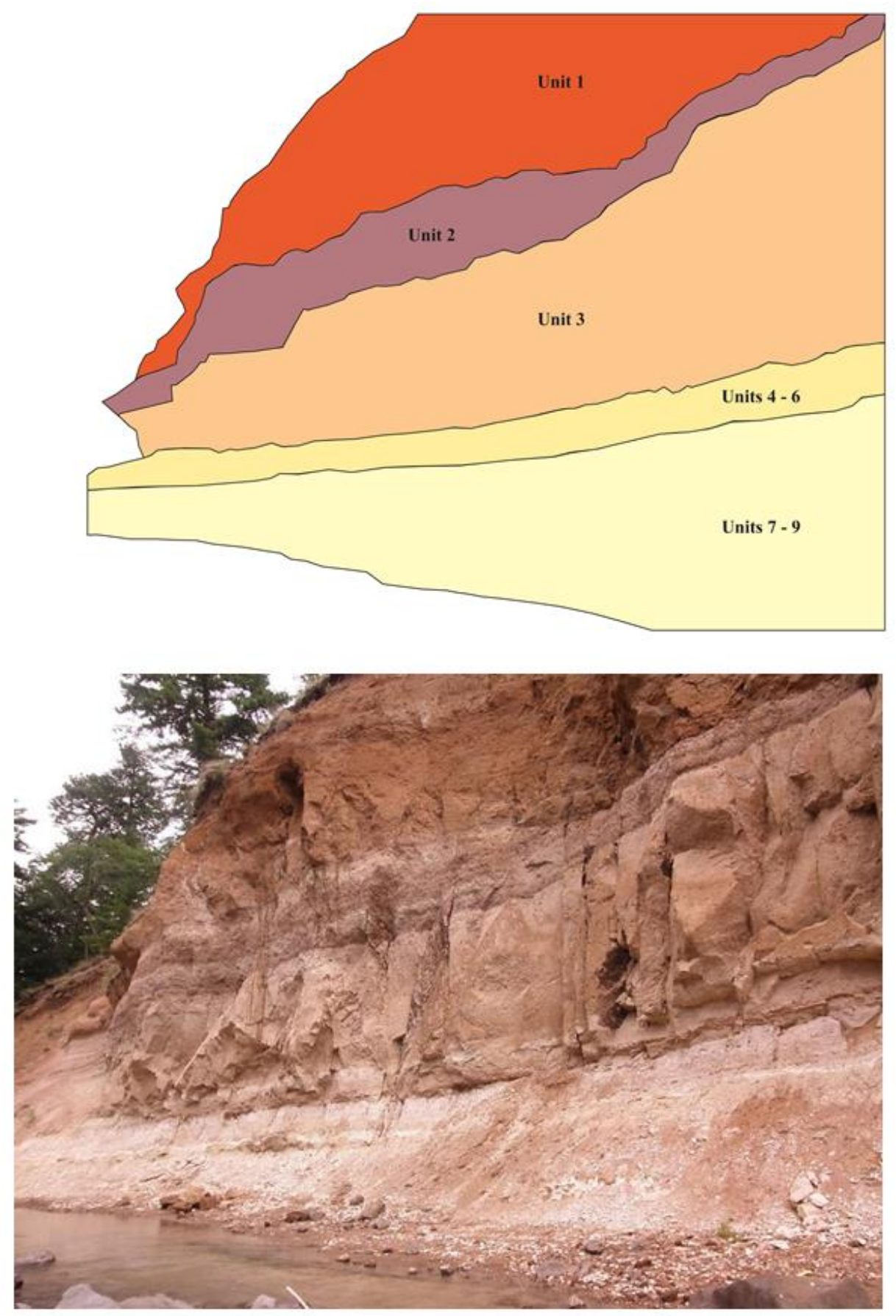

Figure 12. Schematic diagram and image of sedimentary units downstream of the White River Crossing bridge on the south side of the White River. Height of exposure in image is $\sim 15$ meters. 
The upper unit just beneath the vegetation varies in thickness, is generally reddish to brown colored, disorganized, poorly sorted, and has a sharp contact with the lower unit. The matrix is approximately $\sim 88-177 \mu \mathrm{m}$ and grains are angular, with some subrounded 3-5 mm sized yellow pumice and red scoria $0.5-1 \mathrm{~cm}$ in size.

Unit 2 bedding is poorly indurated and wavy, comprised of ash and lapilli. The lapilli is muted or pastel shades of brown, red, and gray. Clasts are red scoria granules, some with hot red to orange interiors, angular to subrounded, frequently to $2 \mathrm{~cm}$, and very angular clasts of nonvesiculated aphyric red lava. The matrix is a creamy-yellow $\operatorname{ash}(\sim 90 \mu \mathrm{m})$.

Unit 3 is crystal-lithic coarse volcanic sandstone. The bedding is massive and grading is uncertain due to limited access and cliff-like exposure. The matrix is of two sizes; one is $88-177 \mu \mathrm{m}$ (average) with some fragments even finer, and the second is coarse 1-2 mm rounded to subangular grains. Clasts include red scoria in the upper $0.6 \mathrm{~m}$ of the unit, and small yellow pumices throughout.

Units 4 through 6 consist of thin beds of fine volcanic sandstone. Unit 4 is comprised of angular grains up $\sim 125 \mu \mathrm{m}$ in size with sharp, planar, parallel or irregular fining up sequences. The crystal-lithic sandstone is poorly indurated and can include flattened pumice up to $1 \mathrm{~cm}$ in length, and red spherical scoria to $\sim 4 \mathrm{~mm}$. Unit 5 is poorly indurated volcanic sandstone with a matrix grain size of $\sim 88 \mu \mathrm{m}$ and spherical yellow pumice and red scoria to $1 \mathrm{~mm}$. Unit 6 is composed of angular creamy-yellow ash of $\sim 125 \mu \mathrm{m}$. Clasts are red scoria from $3 \mathrm{~mm}$ to $6 \mathrm{~cm}$ and yellowish-green, crystal- 
rich pumice from $3 \mathrm{~mm}$ to $1 \mathrm{~cm}$. Bedding is wavy and fines upward for a sharp contact with the upper unit.

Unit 7 is a white to greenish-white bed that is poorly indurated with wavy contacts. The grain size is $\sim 62 \mu \mathrm{m}$ and particles are angular. Unit 8 consists of a thin sequence of coarse crystals, fine ash and coarse crystals, before fining upward. The grain size is $\sim 62 \mu \mathrm{m}$ with flattened glassy fiamme to $\sim 1 \mathrm{~cm}$ in length. Unit 9 is at the river level and a shelf is observed extending below the water level. The grain size is $\sim 88 \mu \mathrm{m}$ and grains are angular to subangular. Clasts include a few red scoria of $\sim 2 \mathrm{~cm}$ or less and some yellow to greenish-yellow pumice.

\section{Ash-flow Tuff Near Quarry (Qt)}

The non-welded ash-flow tuff is located along the White River Crossing Road near the top of the north side of the White River canyon $\left(45.162374^{\circ},-121.3091732^{\circ}\right)$ (Figure 13). The tuff exposure is $\sim 8 \mathrm{~m}$ in thickness and the base of the tuff is concealed. The matrix consists of cream-colored ash, translucent crystals $(125-177 \mu \mathrm{m})$, and subrounded pumices (1-15 cm on the longest side) with stretched vesicle channels. The deposit includes small gray or red angular lithics $(1-2 \mathrm{~cm})$. The ash-flow tuff is cut (with sharp contacts) by a paleochannel of rounded cobbles. Other tuff units are found at similar elevations exposed along primitive roads in the White River canyon $(\sim 540 \mathrm{~m}$ ASL), but none are as laterally extensive as this unit along the White River Crossing Road. 


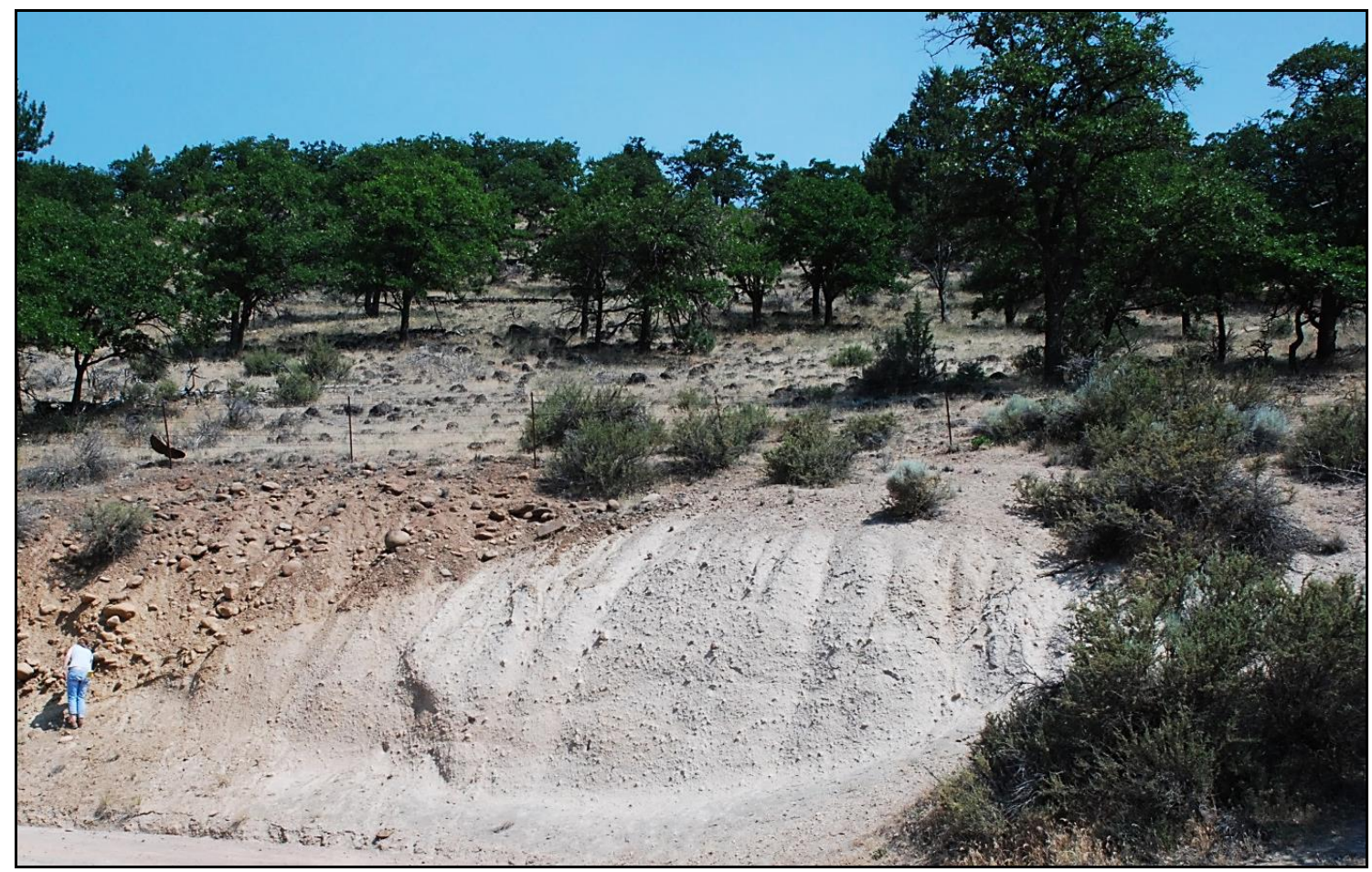

Figure 13. View to the northeast from the White River Crossing Road and ash-flow tuff. Person at left of image (1.7 $\mathrm{m}$ tall for scale) is examining a channel cut filled with rounded cobbles.

\section{Fluvially-transported Deposits (Qal, QI)}

The White River canyon has several exposed paleochannels, now stranded high above water line. Channels range in size from as little as $8 \mathrm{~m}$ to as much as $100 \mathrm{~m}$ (see example in Figure 14 , located at $45.159202^{\circ},-121.3119644^{\circ}$, east of the White River Crossing bridge). The channels are flat-bottomed to arcuate, filled with rounded to subrounded medium-gray cobbles, some of which are $15 \mathrm{~cm}$ or larger. The mafic cobbles are commonly vesiculated and plagioclase-rich. 


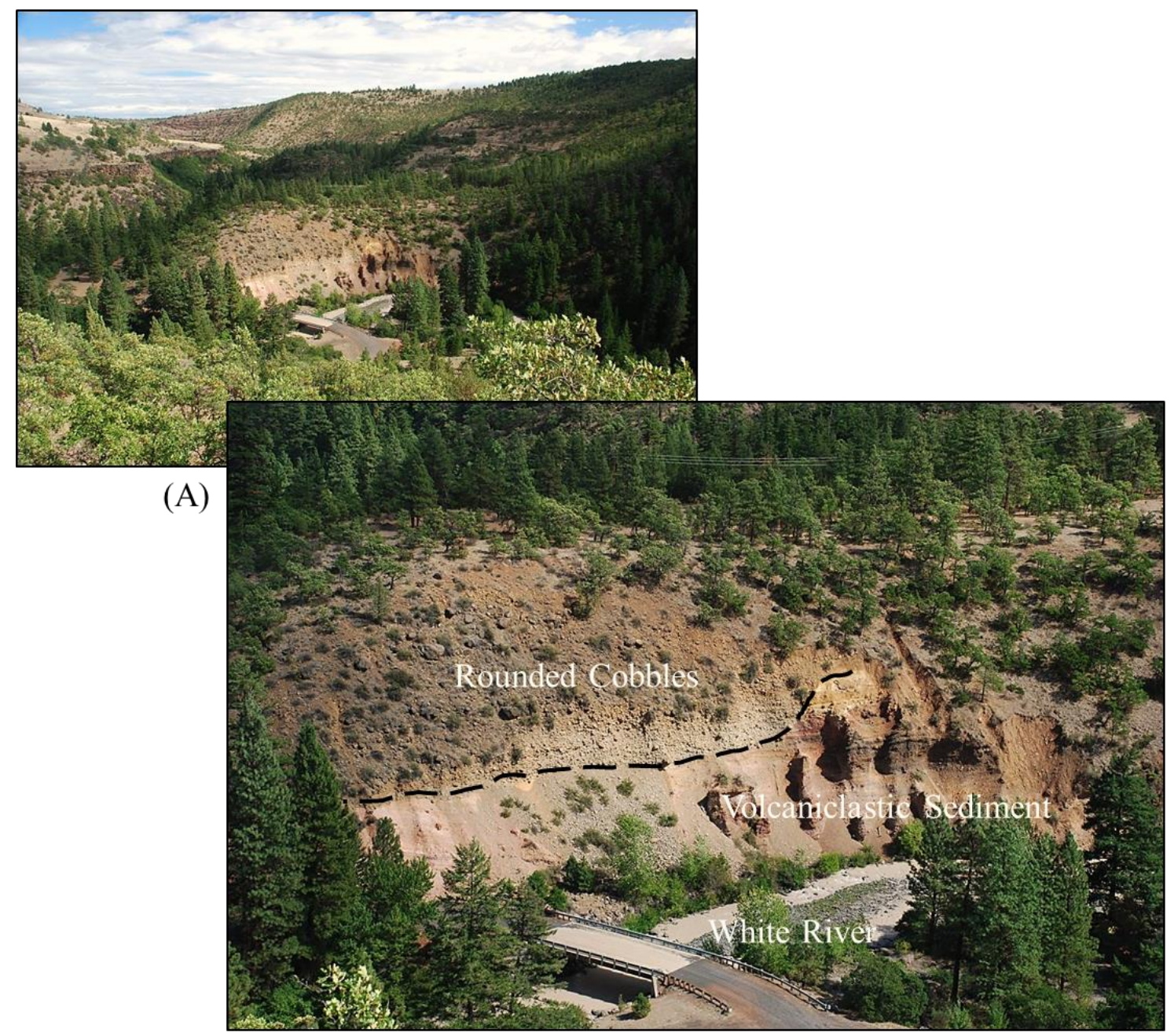

(B)

Figure 14. (A) Upper image shows wide view of White River Canyon (looking east or downstream); (B) magnified section of image with dashed line and annotation showing the base of a paleochannel with rounded cobbles cutting into volcaniclastic sediment. The White River Crossing bridge is in the bottom center. 
A debris flow fills a paleochannel carved into volcaniclastic sediment $\left(45.159885^{\circ},-121.3076692^{\circ}\right)$ downstream of the White River Crossing bridge (Figure 15). The bed is chaotic, poorly sorted, brownish in color, consisting of lenticular, poorly indurated clumps of sand-sized particles and larger angular blocks. The steep exposure precluded careful study, but chunks collected below the deposit are similar to Units 3 and 4 at the Wasco County quarry (see Figure 11).

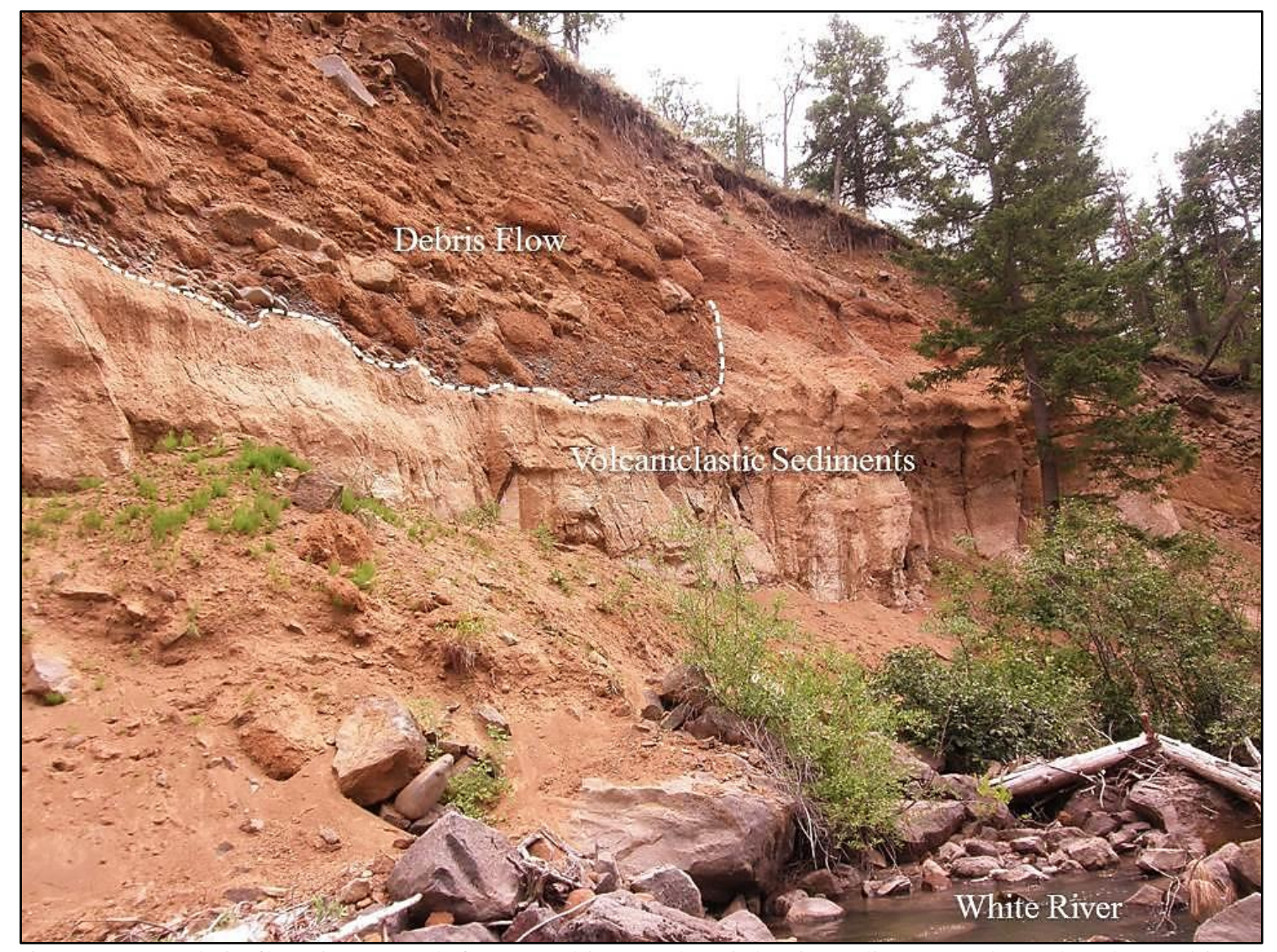

Figure 15. Debris flow in upper left, carved into volcaniclastic sediment. The paleochannel is approximately $5 \mathrm{~m}$ above the modern-day river channel.

\section{Soils $(\mathbf{Q c})$}

Soils in and around Graveyard Butte include: (1) the Bakeoven-Watama complex, formed from loess, volcanic ash, and residuum weathered from basalt; (2) 
Hesslan and Hesslan-Skyline complex, comprised of volcanic ash and colluvium derived from sediments and sandstone; (3) Wamic loam and Wamic-Skyline complex, formed from alluvium or colluvium derived from basalt or andesite overlain by volcanic ash and loess; and (4) Watama-Wapinitia silt loams comprised of loess and volcanic ash. Soil depths to bedrock are generally $30 \mathrm{~cm}$ to no more than $152 \mathrm{~cm}$, depending on location (Soil Survey Staff, undated). 


\section{Petrography of Graveyard Butte Units}

\section{A. Rhyolites}

Graveyard Butte rhyolites (see, for example, samples WR13 (Table 3), S6-13 and X3 (Table 4)) are variably porphyritic, with crystal abundances from 3\% to $7 \%$. The crystal assemblage contains plagioclase, clinopyroxene (Figure 16), fayalitic olivine (Figure 17), quartz, ilmentite, magnetite and accessory phase zircon and apatite (see also Appendix C. Energy Dispersive Spectra (EDS)).

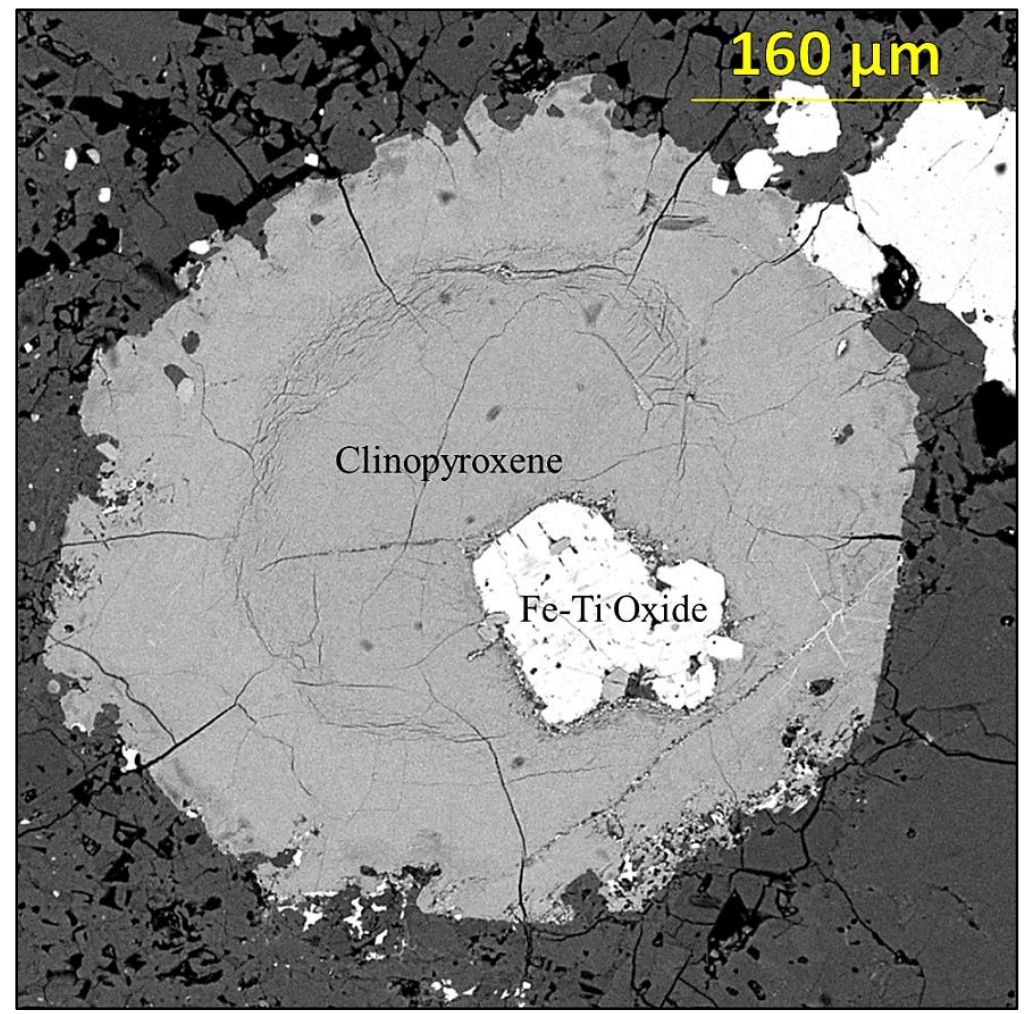

Figure 16. Backscatter electron micrograph of sample S6-13, with clinopyroxene and Fe-Ti oxide. 


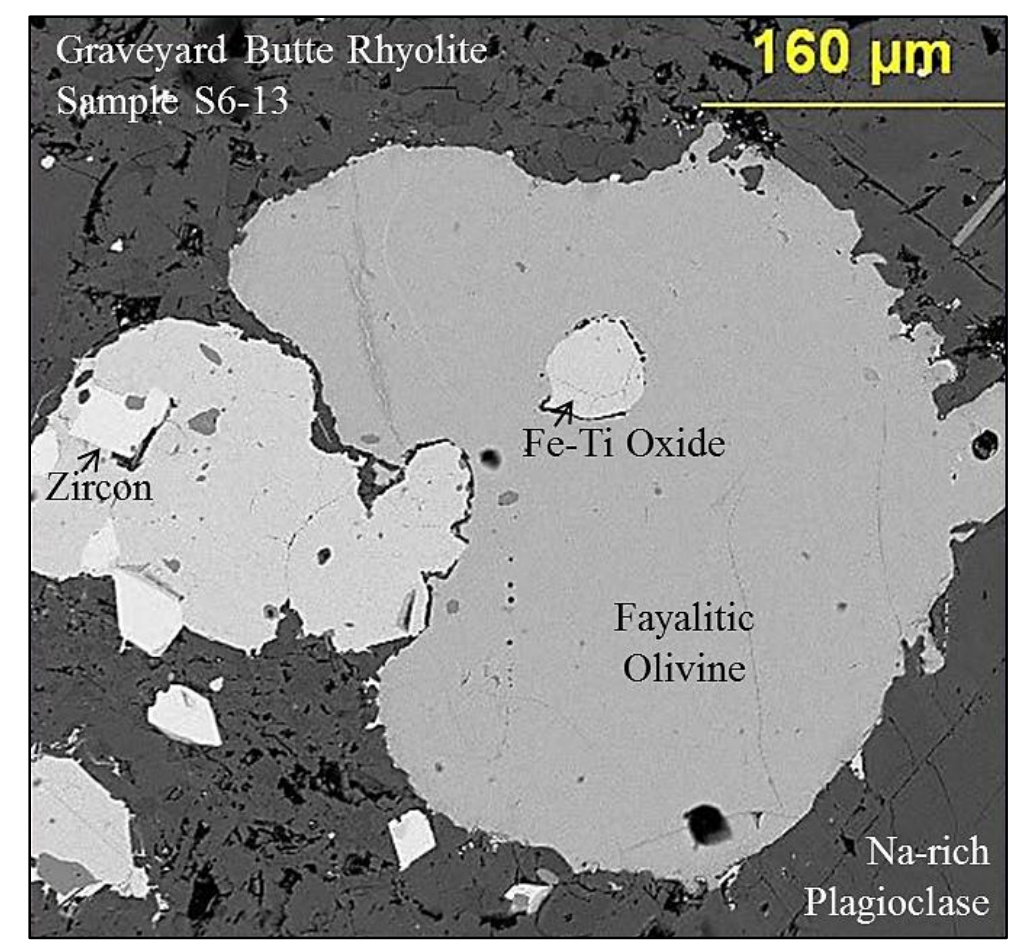

Figure 17. Backscatter electron micrograph of sample S6-13, a flow-banded rhyolite, with Narich plagioclase, fayalitic olivine, Fe-Ti oxide and zircon.

The subhedral plagioclase is blocky to rectangular with irregular edges characterized by new mineral overgrowths; some phenocrysts display a wormy interior. Twin margins are commonly blurred. The subhedral clinopyroxene is fractured and embayed and the fayalitic olivine is subrounded (Figure 17). The quartz is subhedral and frequently observed under microscope with undulose extinction. The samples include Fe-Ti oxides $(\sim 45 \mu \mathrm{m})$ and sample S6-13 contains zircon $(\sim 37 \mu \mathrm{m})$. Sample X3 includes a mafic enclave with plagioclase and clinopyroxene, similar to that observed in basalt sample WR11 (Figure 18, see also Figure 19). Small phenocrysts line the elongated vesicles that define flow-banding. 


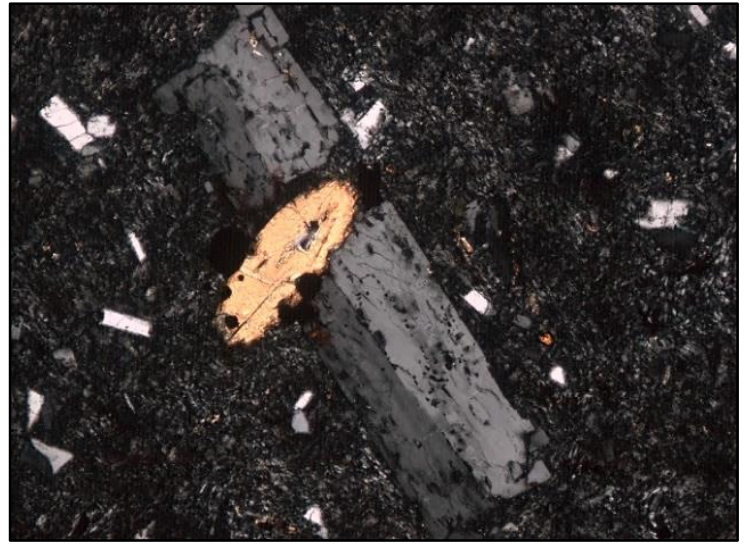

(A)

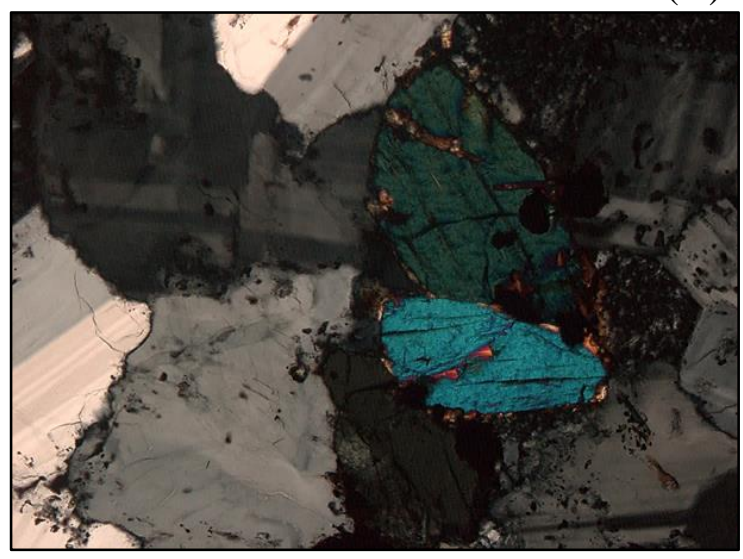

(C)

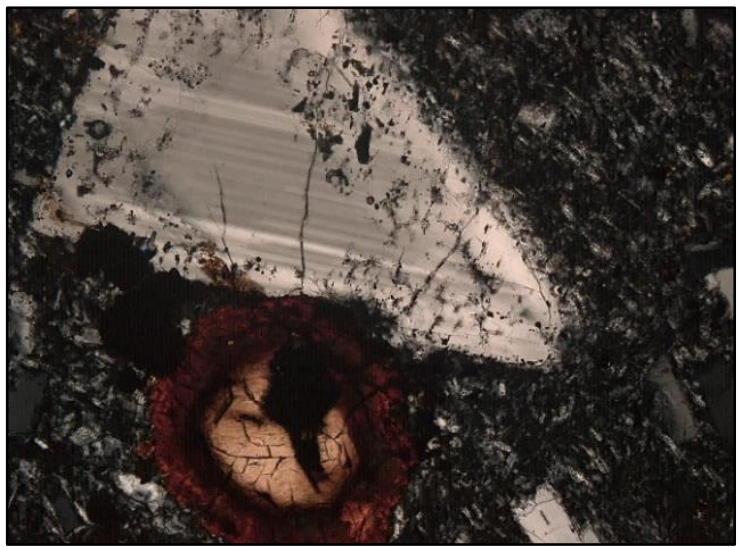

(B)

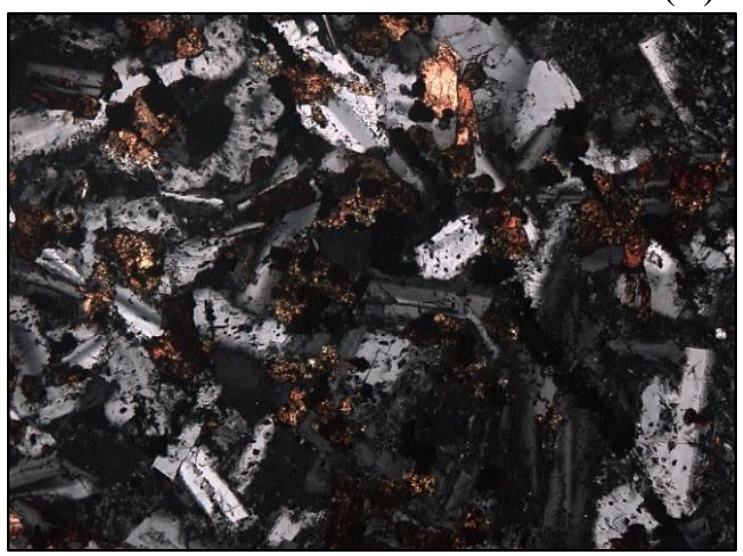

(D)

Figure 18. Representative examples of Graveyard Butte rhyolite crystal assemblages: (A) sample WR13 show feldspar with ragged margins (magnification 5x); (B) sample S6-13 clinopyroxene (brown) and plagioclase (magnification 10x); (C) sample X3 crystal clot (magnification 10x); (D) sample X3 includes a mafic enclave (magnification 10x). All images under cross-polarized light.

\section{B. Basalts}

The basalt (sample WR11 (Table 3)) texture is equigranular to

glomeroporphyritic, with plagioclase feldspar, Mg-rich olivine, clinopyroxene

phenocrysts and microphenocrysts in an intersertal to intergranular groundmass. The plagioclase is commonly found as subhedral laths $900-1300 \mu \mathrm{m}$. The plagioclase is polysynthetic twinned, commonly with blurred margins between twins. Edges can include embayments creating a ragged appearance. Some have a sieved or spongy interior. The 
plagioclase can be zoned, with an exterior higher in sodium as confirmed with EDS

(Figure 19, see also Appendix C. Energy Dispersive Spectra).

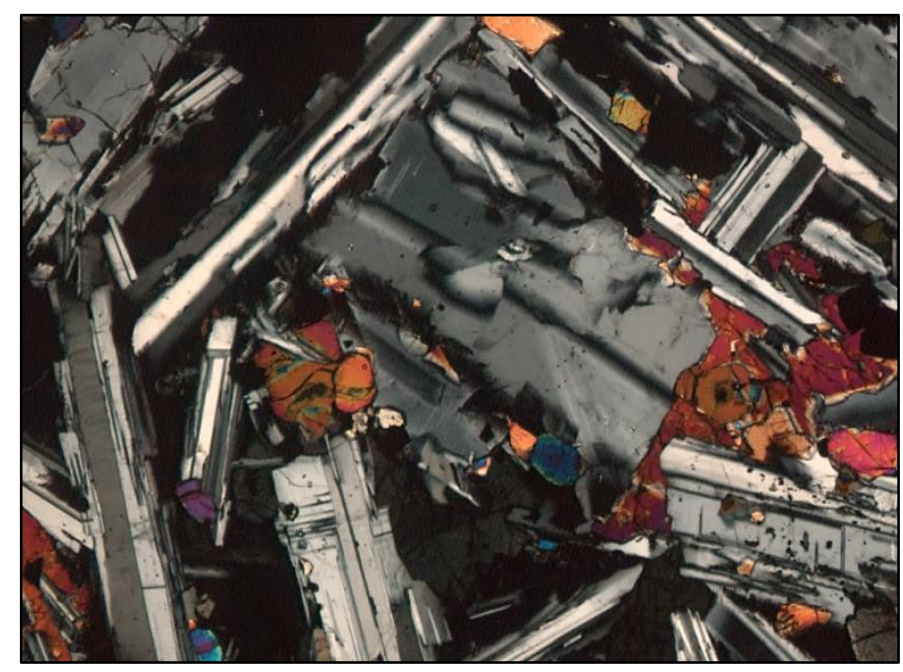

(A)

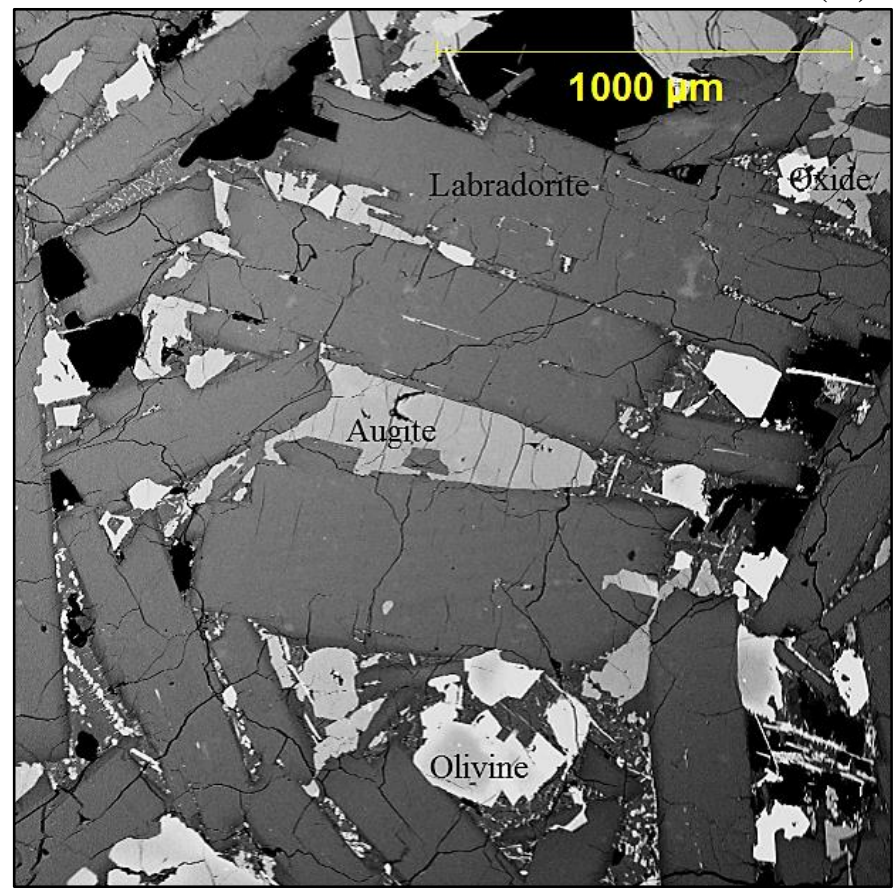

(B)

Figure 19. Sample WR11 as viewed (A) under petrographic microscope with crossed-polarized light, and (B) as an annotated backscatter electron micrograph. 
The olivines are 200-600 $\mu \mathrm{m}$, subhedral to anhedral and fractured (Figure 19). The olivines are commonly surrounded by pyroxene and oxides; Fe-Ti oxides can occur at rim margins. Subhedral clinopyroxene are rounded, 400-800 $\mu \mathrm{m}$, and typically occur with olivine. Secondary minerals include zeolite $(\sim 20-30 \mu \mathrm{m}$ subhedral clinoptilite $)$ and Fe-Ti oxides.

\section{Andesites}

In hand samples, the andesites are commonly glassy (black or red) with less than 5\% phenocrysts. Primary minerals include plagioclase feldspar (labradorite), clinopyroxene and Fe-Ti oxides. The larger plagioclase phenocrysts are subhedral ( 350 $\mu \mathrm{m})$ with poly-synthetic twins or two to four Carlsbad twins. All edges, including the short edge, can include embayments. The intermediate-sized plagioclase $(\sim 125 \mu \mathrm{m})$ is subhedral with sharp long margins and edges. Also observed are plagioclase microlaths that show some alignment on the long edges (Figure 20$)$. The smaller plagioclase $(\sim 42$ $\mu \mathrm{m}$ ) has higher calcium interiors and more sodic rims (see Appendix C. Energy Dispersive Spectra). The Fe-Ti oxides are subhedral, up to $400 \mu \mathrm{m}$ in length. The rock sample includes a rounded melt inclusion with labradorite, clinopyroxene and oxides (Figure 21). 

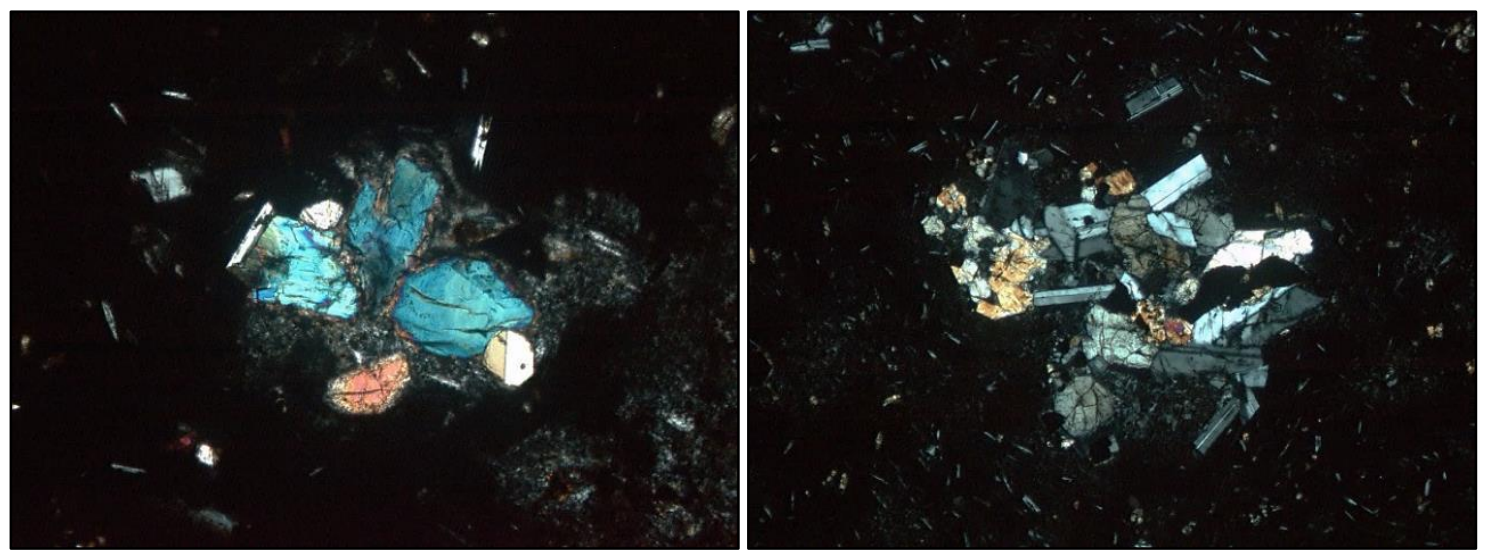

(A)

(B)
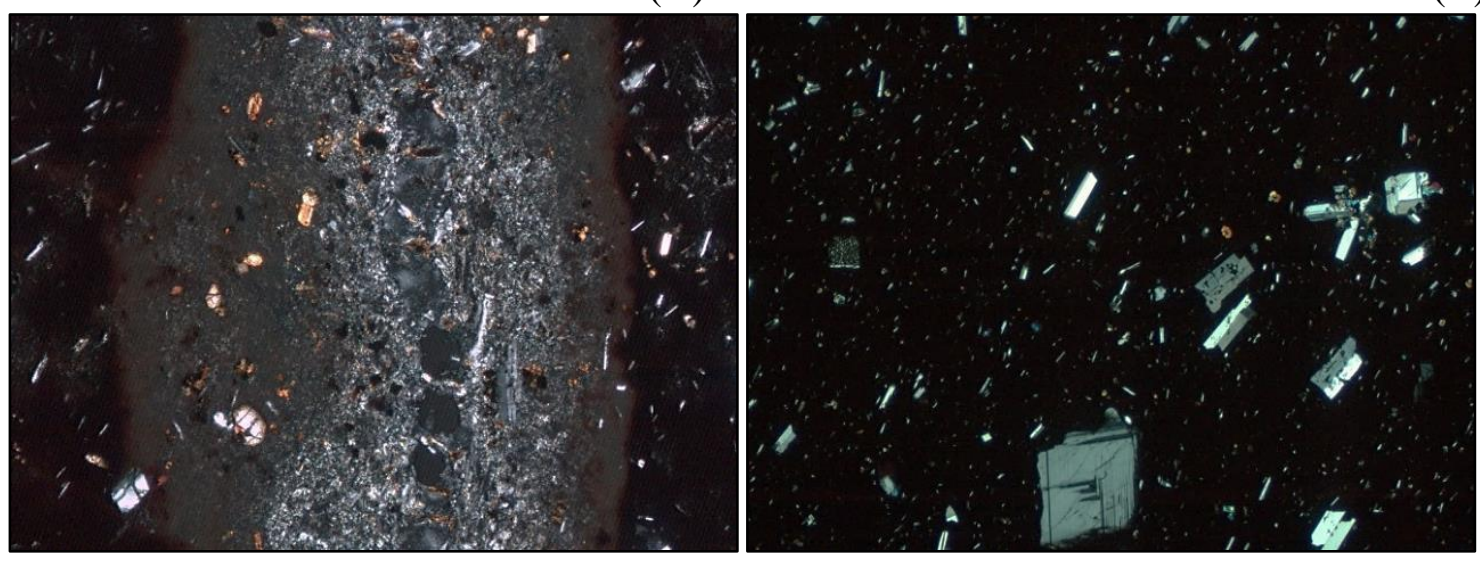

(C)

(D)

Figure 20. Illustrative examples of Graveyard Butte andesites: (A) sample S12-6 (magnification 10x); (B) sample S12-6 (magnification 5x) (C) sample S12-6 vein (magnification 5x); (D) sample V1 (magnification 2.5x). All images under cross-polarized light. 


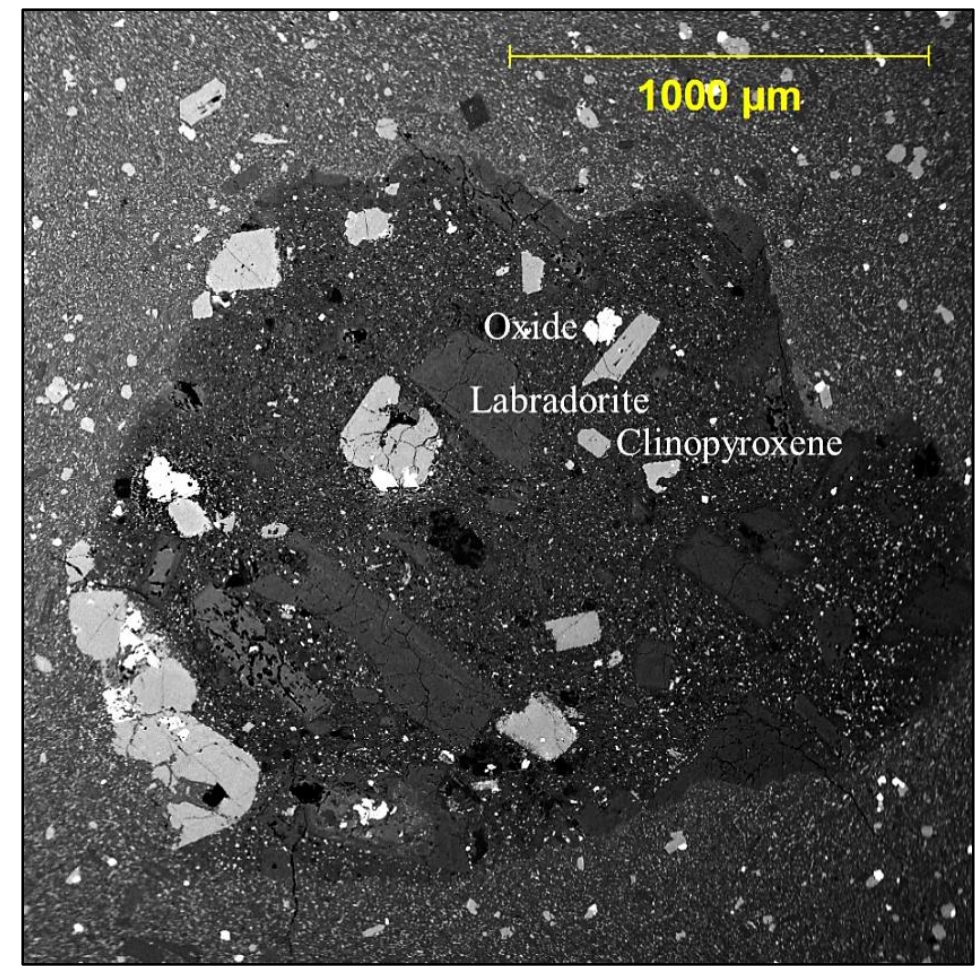

Figure 21. Sample V1 includes a rounded melt inclusion, with zoned plagioclase, clinopyroxene and oxides. 


\section{Geochemical Classification and Composition of Graveyard Butte Units with Comparison to Gordon Butte}

Selected samples were prepared for bulk geochemical analysis (see Appendix A.

Methods, for sample processing and analytical procedures), including rocks from Gordon

Butte. Gordon Butte is the closest source of silicic rocks to Graveyard Butte (Sherrod

and Scott, 1995), some $18 \mathrm{~km}$ distant. A comparison of geochemical data from both

buttes provides the means to analyze trends and consider regional influences on magma

compositions.

Lavas at Gordon Butte were sampled at several locations — one along Badger

Creek and a second group of samples were taken at various locations from the butte's Upper Slopes (Figure 22).

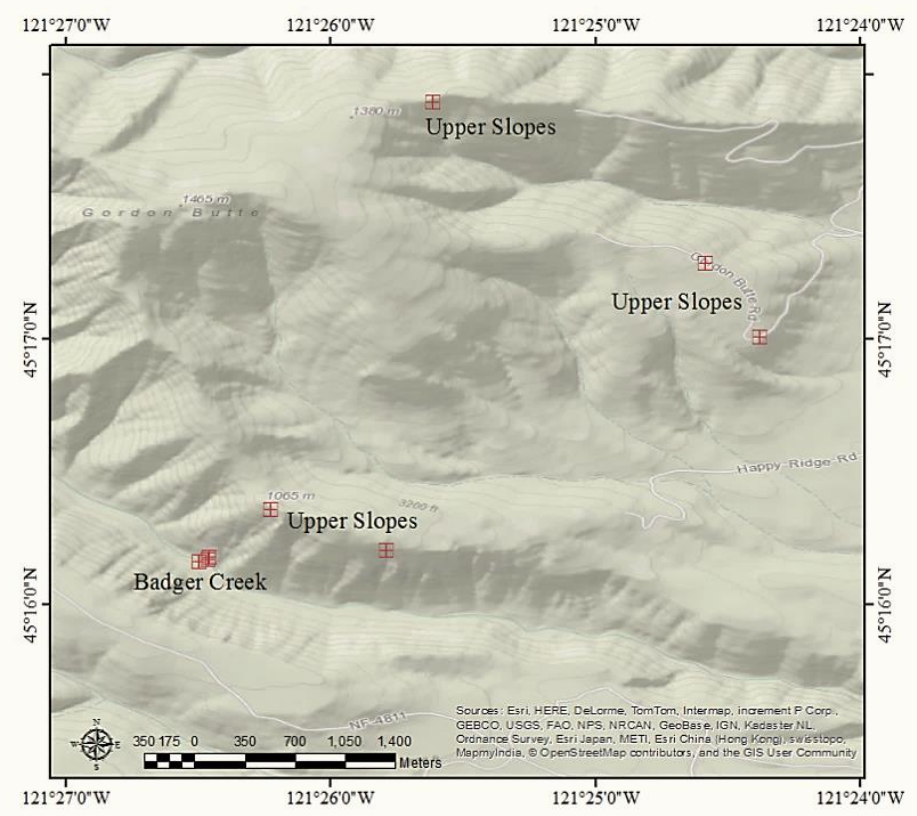

Figure 22. Map of Gordon Butte rhyolite sample locations at Badger Creek and Upper Slopes. Basemap from ESRI. Map scale is 1:30,000. 
Rhyolite sample locations at Graveyard Butte were in the western canyon, central canyon or quarry, and eastern canyon (Figure 23). Figure 9 shows the sample locations of the andesites and basalts.

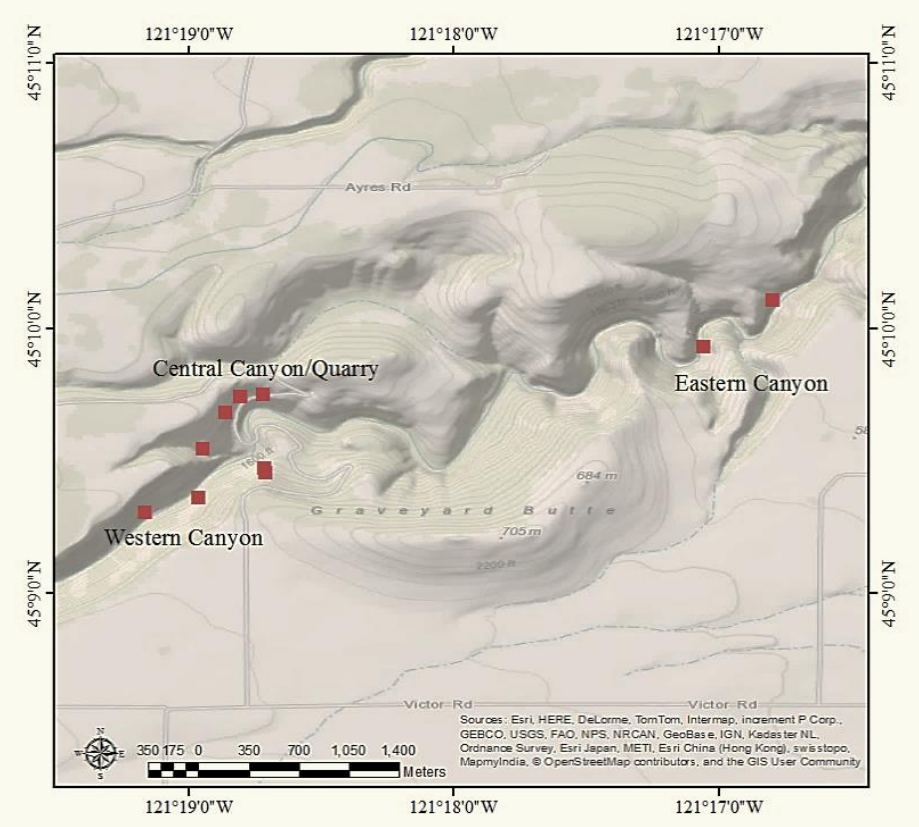

Figure 23. Sample locations for Graveyard Butte include the western canyon, central canyon or quarry and eastern canyon. Basemap from ESRI. Map scale is 1:30,000.

As shown in Figure 24, the igneous rocks at Graveyard Butte are basalt, basaltic andesite, andesite, trachyandesite, and rhyolite (see data in Appendix D. Geochemical Data, Table 3, Table 4, and Table 5). The samples collected at Gordon Butte are exclusively rhyolite (see Appendix D. Geochemical Data, Table 6). The rhyolite ranges from 69.01 to 74.08 wt. $\% \mathrm{SiO}_{2}$, the basalt ranges from 49.5 to 50.1 wt. $\% \mathrm{SiO}_{2}$ with $\mathrm{Mg}$ numbers that range from 49.1 to 54.5 , and the andesites range from 56.9 to $62.4 \mathrm{wt} . \%$ $\mathrm{SiO}_{2}$. 


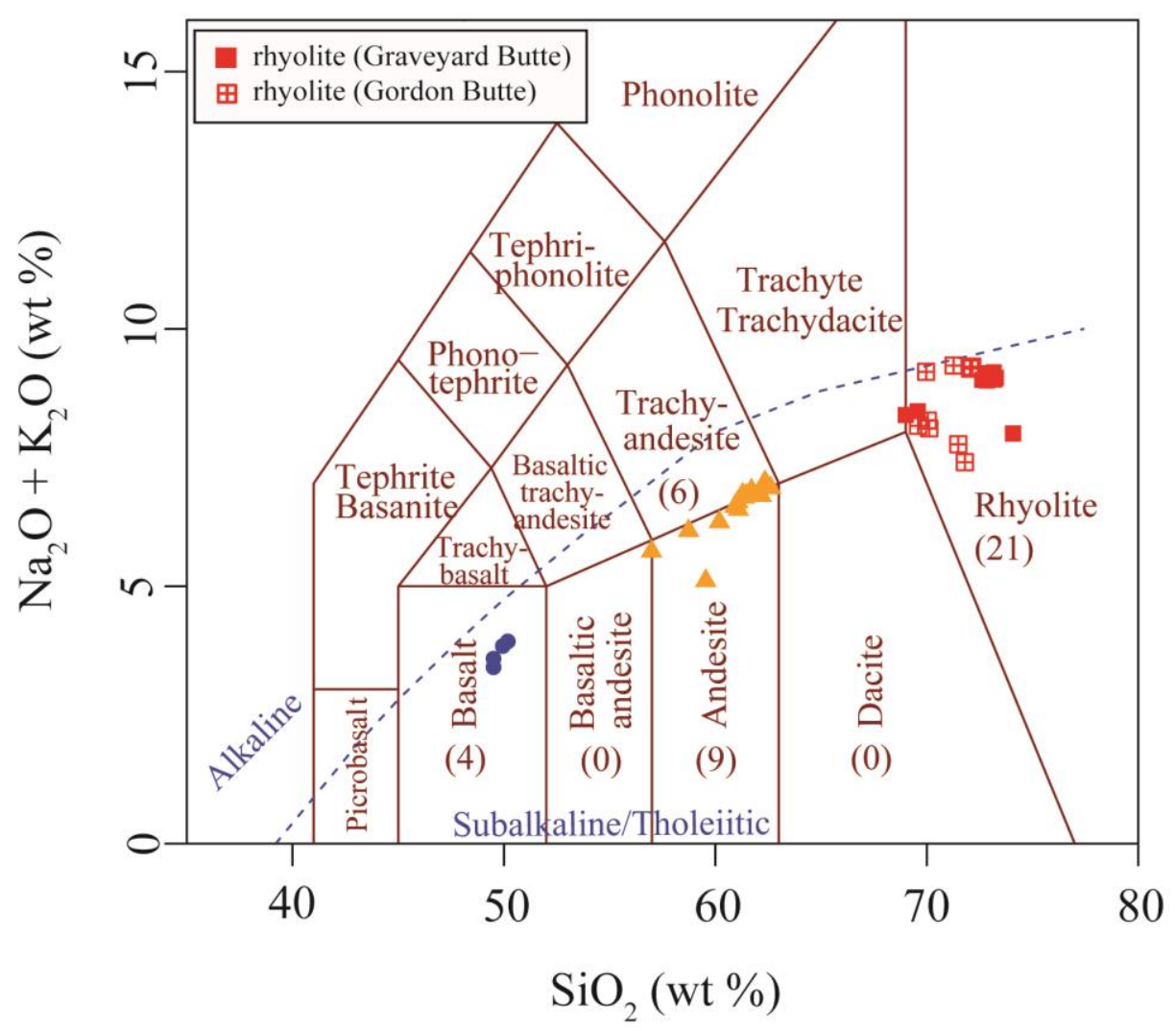

Figure 24. Classification of 40 geochemical samples from Graveyard Butte (solid symbols) and Gordon Butte (open red squares with cross). The data consists of four basalts, nine andesites, six trachyandesites, and 21 rhyolites. All samples are subalkaline/tholeiitic. Total Alkalis-silica classification after LeBas et al., 1986; alkaline, subalkaline/tholeiitic fields after Cox et al., 1979.

The rhyolite samples are tholeiitic in character, while andesites and basalts plot along the border of the tholeiitic and calc-alkaline trend (Figure 25(A)). The rhyolite shows variability in the total iron $\left(\mathrm{FeO}_{\mathrm{t}}\right)$ to magnesium $(\mathrm{Mg})$ ratio compared to the andesites and basalts. The rhyolites are high-potassium (K), while andesites and basalts (with the exception of one sample) are within the medium-K range (Figure 25(B)). 


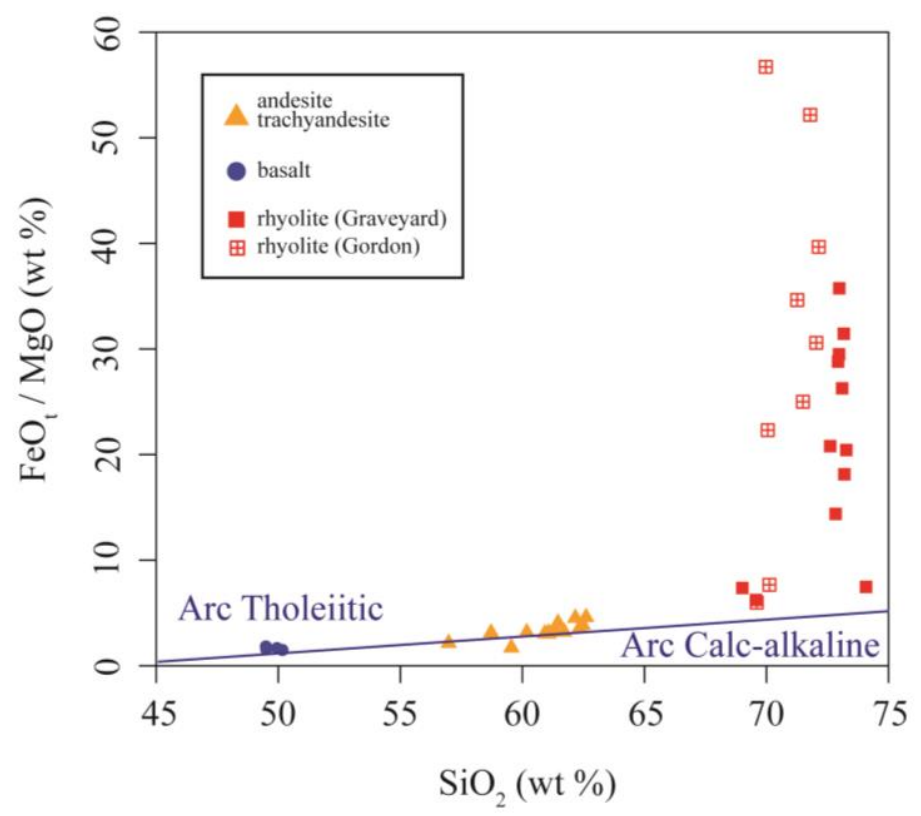

(A)

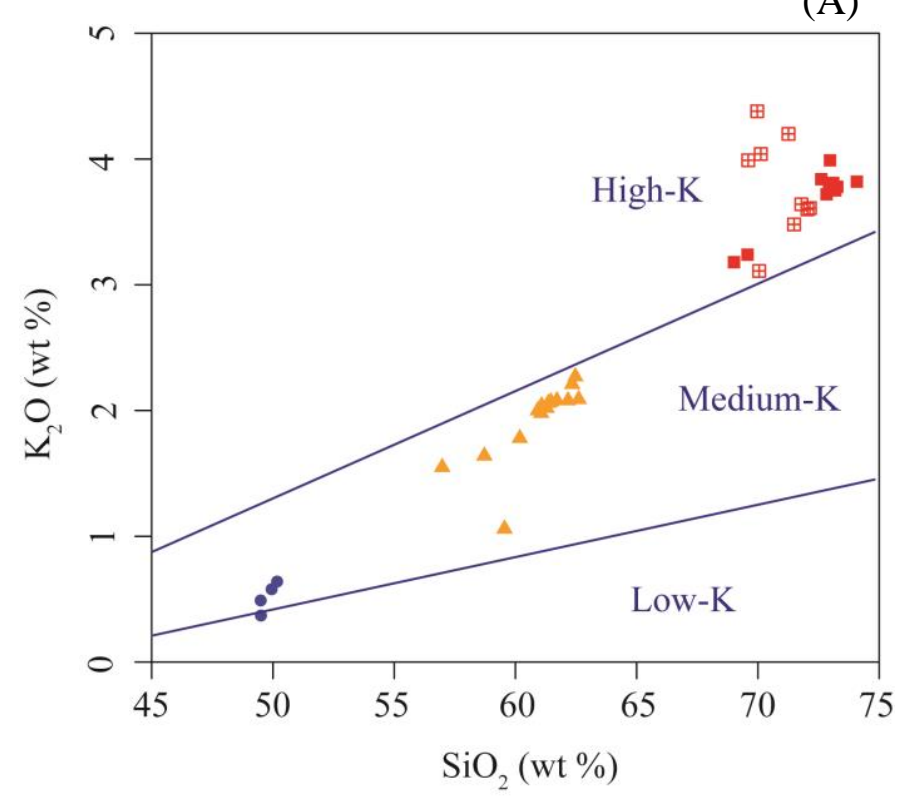

(B)

Figure 25. (A) Rhyolites show variability in $\mathrm{FeO}_{\mathrm{t}} / \mathrm{MgO}_{(\mathrm{FeO}}$ is total $\left.\mathrm{Fe}\right)$ compared to andesites and basalts; samples plot almost exclusively in the tholeiitic field (boundaries from LeBas et al., 1986). (B) Rhyolites are high-K, while andesites and basalts (with one exception) are medium-K (suite boundaries from Ewart, 1982). 
The rhyolites from Graveyard Butte (with the exception of the ash-flow tuff) and Gordon Butte's Badger Creek have distinctly higher concentrations of high field strength elements (HFSE) such as zirconium (Zr) (Figure 26) and lower concentrations of fluidmobile elements like strontium (Sr) (Figure 27), than samples from Gordon Butte's Upper Slopes and the ash-flow tuff.

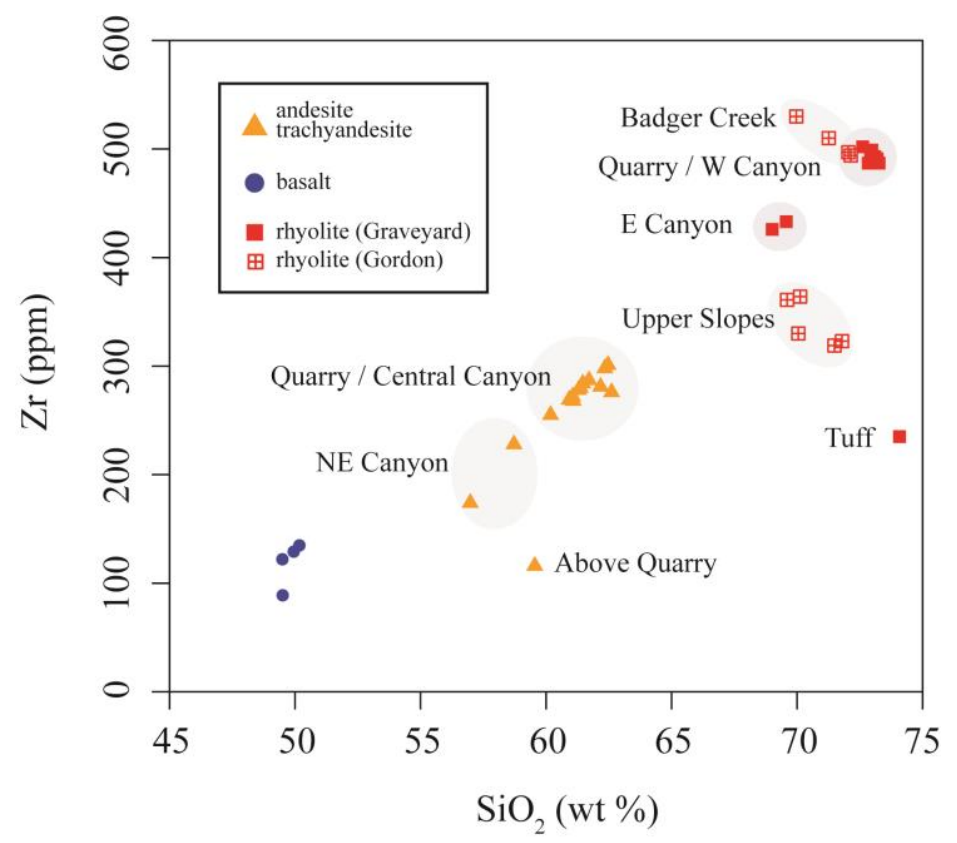

Figure 26. Comparison of $\mathrm{Zr}$ versus $\mathrm{SiO}_{2}$ by location (symbols as in Figure 24). Two sample locations are distinguished for Gordon Butte (Badger Creek and Upper Slopes) and six for Graveyard Butte (E Canyon, W Canyon, Central Canyon, Quarry, Above Quarry, and Tuff). For the rhyolites, the Badger Creek and most Graveyard Butte samples have higher $\mathrm{Zr}$ than the Upper Slopes and Tuff. 


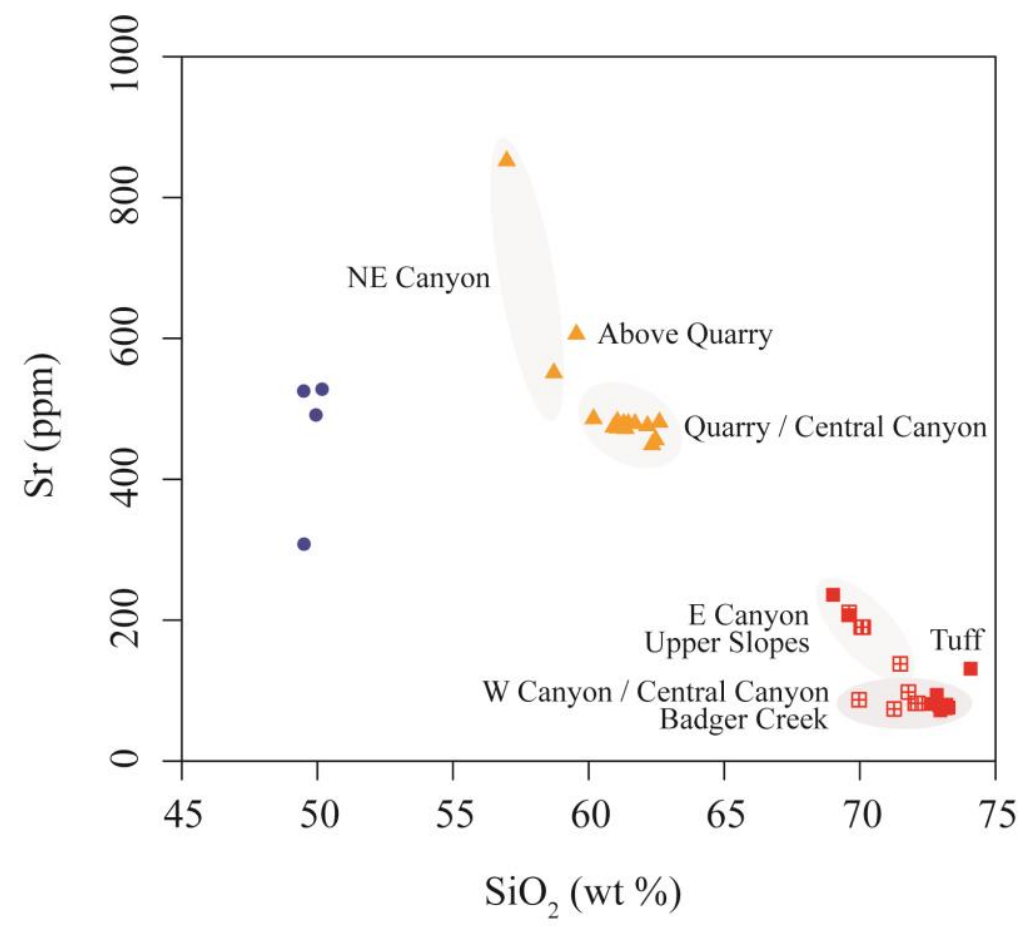

Figure 27. Comparison of $\mathrm{Sr}$ versus $\mathrm{SiO}_{2}$ by location (symbols as in Figure 24, locations described in Figure 26). For the rhyolites, the Badger Creek and most Graveyard Butte samples have lower Sr concentrations than the Upper Slopes and Tuff. 
As shown in Figure 28, the Graveyard Butte and Badger Creek rhyolites show more enriched concentrations in light rare earth elements (LREE or La-Sm in Figure 28) than heavy rare earth elements (HREE or Tb-Lu in Figure 28) and depletion in Europium (Eu). The Gordon Butte Upper Slopes samples in comparison, are less enriched in all of these elements.

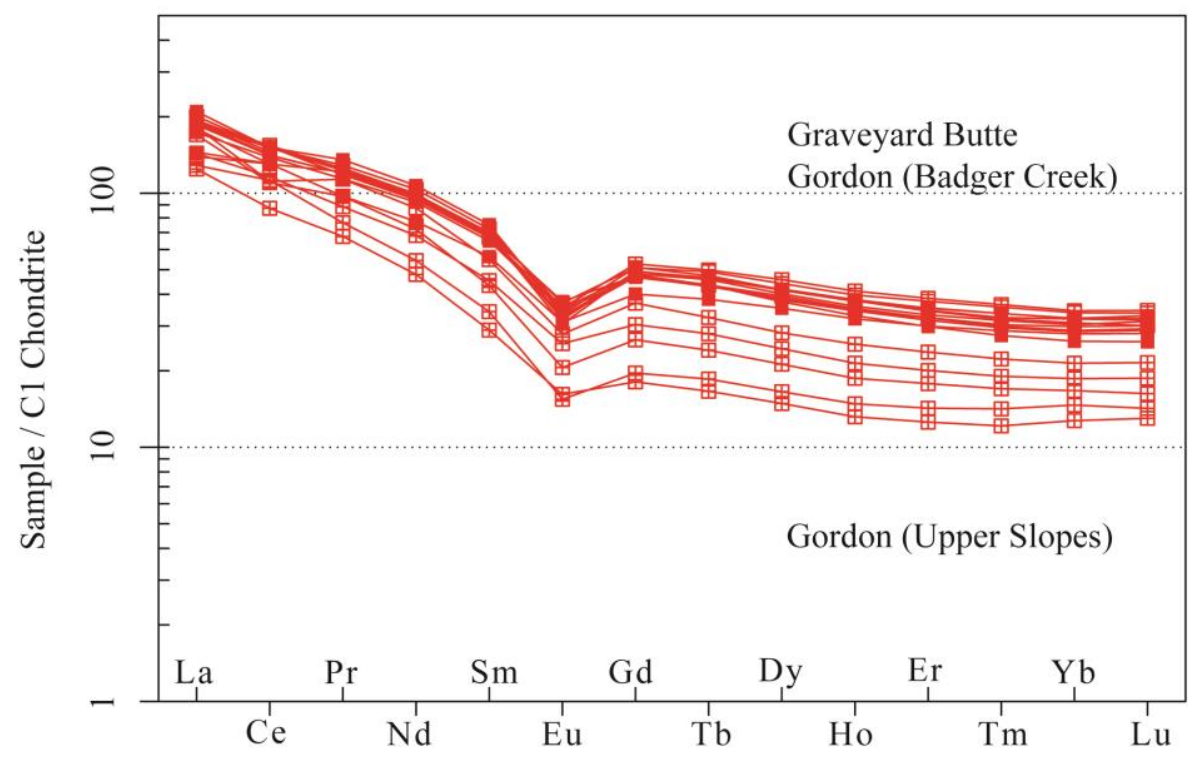

Figure 28. Primitive mantle normalized incompatible trace element pattern for rhyolite samples of Graveyard Butte (filled squares) and Gordon Butte (unfilled squares with cross). The Graveyard and Badger Creek samples have higher concentrations of LREE and HREE than those from Gordon Butte's Upper Slopes. C1 Chondrite normalizing values from McDonough and Sun (1995). 
The basalts are enriched in the fluid-mobile elements barium $(\mathrm{Ba})$ and $\mathrm{Sr}$, with enrichment in uranium $(\mathrm{U})$ and lead $(\mathrm{Pb})$ and depleted in thorium $(\mathrm{Th})$ and $\mathrm{Nb}$ relative to primitive mantle compositions (Figure 29).

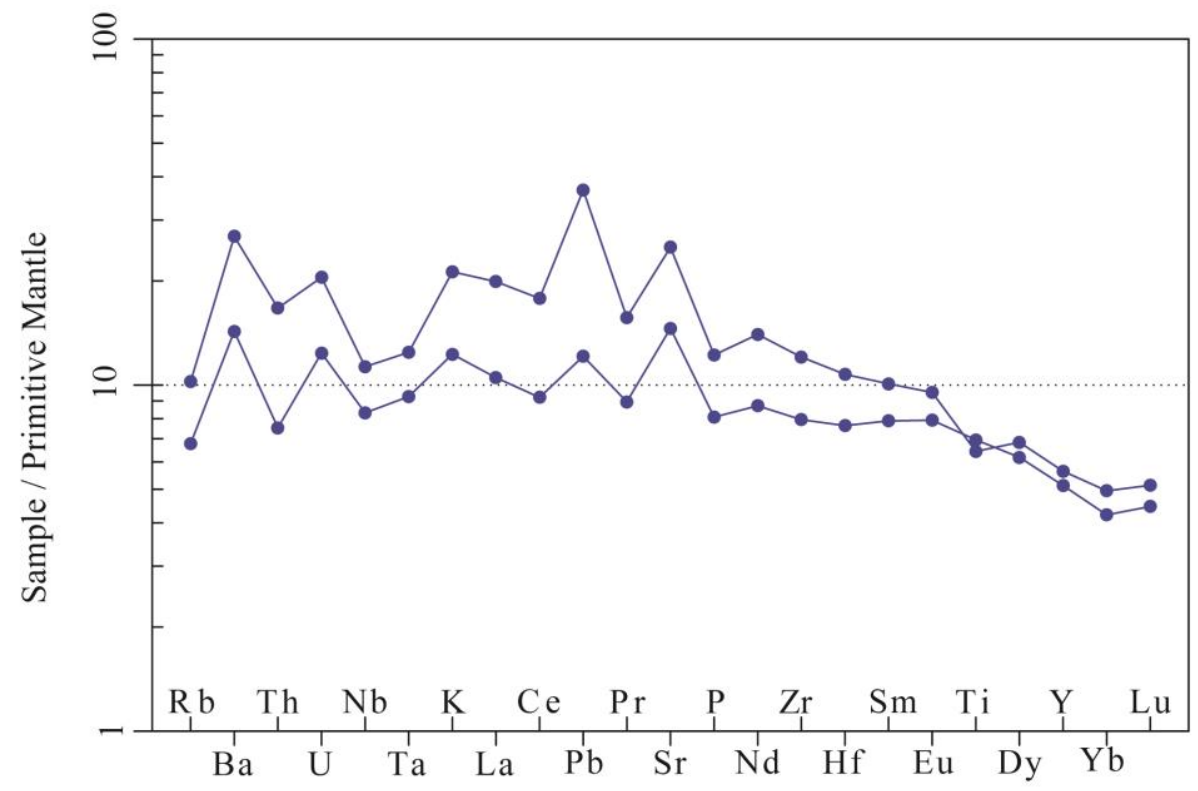

Figure 29. Primitive mantle normalized incompatible trace element pattern for basalt samples shows enrichment in $\mathrm{Ba}, \mathrm{U}, \mathrm{K}, \mathrm{Pb}$ and $\mathrm{Sr}$. Primitive mantle normalizing values from Sun and McDonough (1989). 
With few exceptions, the andesites are enriched in $\mathrm{Ba}, \mathrm{U}, \mathrm{K}$, and $\mathrm{Pb}$, and depleted in $\mathrm{Nb}$, phosphorus (P) and titanium (Ti) (see Figure 30); two andesite samples (samples S6-10U and CC16) are distinctly lower in abundance of all these elements.

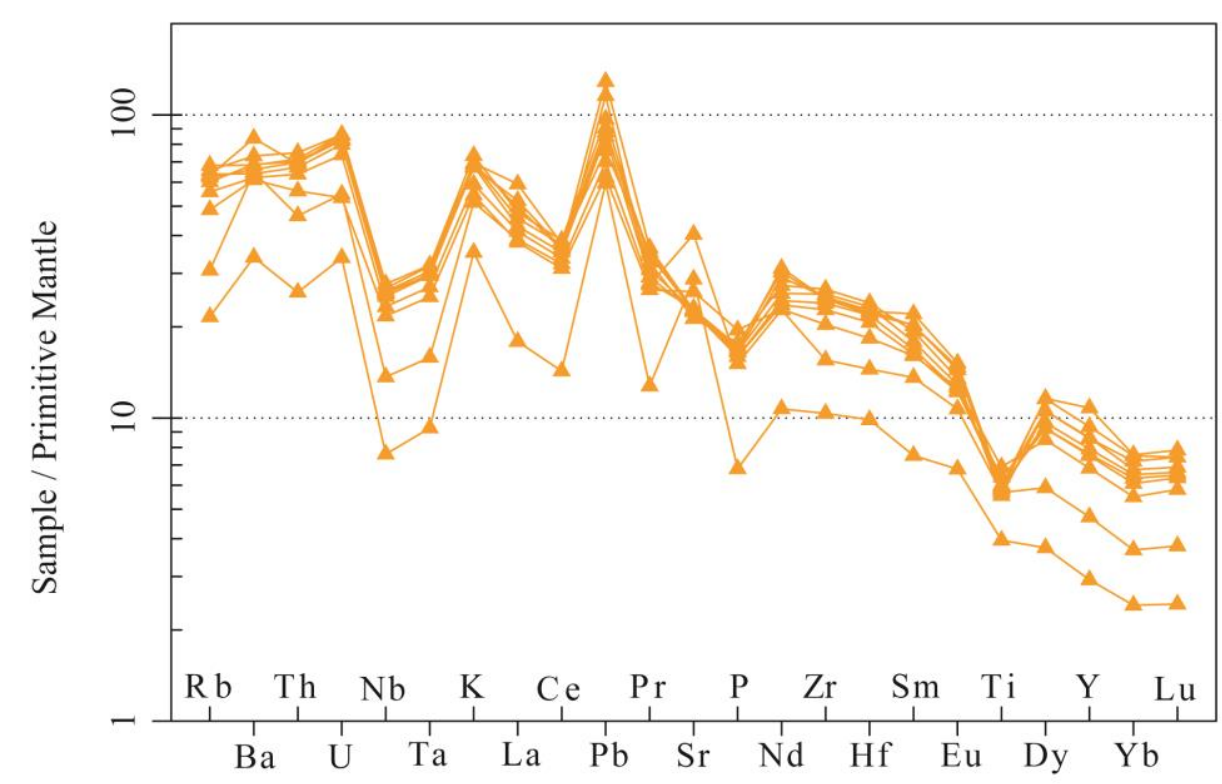

Figure 30. Primitive mantle normalized incompatible element pattern for andesite samples shows enrichment in $\mathrm{Ba}, \mathrm{U}, \mathrm{K}, \mathrm{Pb}$ and $\mathrm{Sr}$, with depletions in $\mathrm{Nb}, \mathrm{Ce}, \mathrm{P}$ and $\mathrm{Ti}$. The two samples with distinctly lower values are S6-10U and CC16. Primitive mantle normalizing values from Sun and McDonough (1989). 


\section{Isotopic Analyses of Rhyolites and Andesite}

\section{A. ${ }^{40} \mathrm{Ar} /{ }^{39} \mathrm{Ar}$ Age Analyses}

The ${ }^{40} \mathrm{Ar} /{ }^{39} \mathrm{Ar}$ geochronology method was used to determine ages of two rhyolite samples from Graveyard Butte (X3, CC14), one rhyolite sample at Gordon Butte (sample GB4-3) and one andesite sample at Graveyard Butte (sample S12-6) (see Appendix A. Methods, for description of processing techniques and analytical procedures). Samples X3 and GB4-3 analyses included both feldspar crystals and groundmass, feldspar was used for sample CC14 and groundmass was used for the crystal-poor sample (CC14) from Graveyard Butte's eastern canyon (see Appendix E. ${ }^{40} \mathrm{Ar} /{ }^{39} \mathrm{Ar}$ Age Results for Graveyard and Gordon Buttes).

Argon release spectra are shown in Figure 31. The Graveyard Butte quarry sample X3 is slightly younger $(3.67 \pm 0.01 \mathrm{Ma})$ than its groundmass $(3.71 \pm 0.01 \mathrm{Ma})$. The same holds true for the rhyolite of Gordon Butte's Badger Creek (GB4-3) with a feldspar date of $3.64 \pm 0.03 \mathrm{Ma}$ and groundmass date of $3.70 \pm 0.01 \mathrm{Ma}$. Sample CC14 is representative of the rhyolite in the eastern White River canyon and has a date of 3.65 \pm 0.01 Ma. Sample S12-6 is from an andesite outcrop at the southwestern portion of the White River canyon, with a date of $3.86 \pm 0.07 \mathrm{Ma}$. The ages described in this research are from the weighted plateau (Figure 31). 


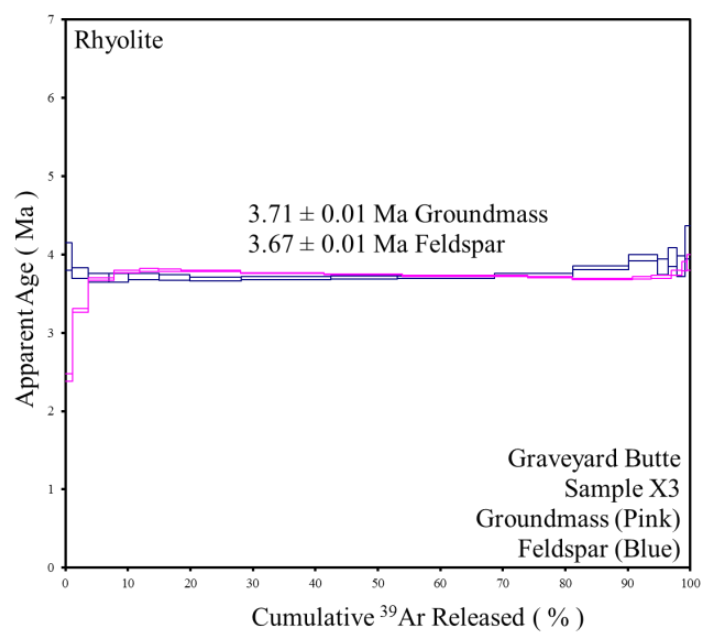

(A)

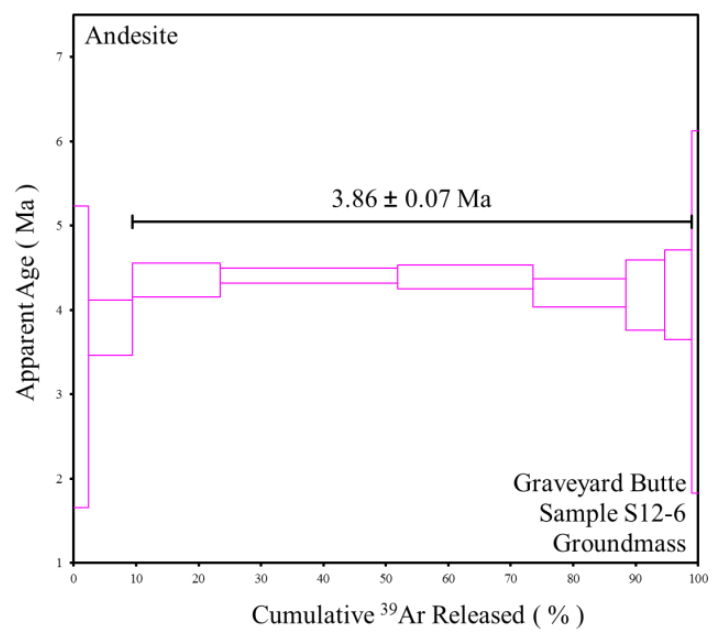

(C)

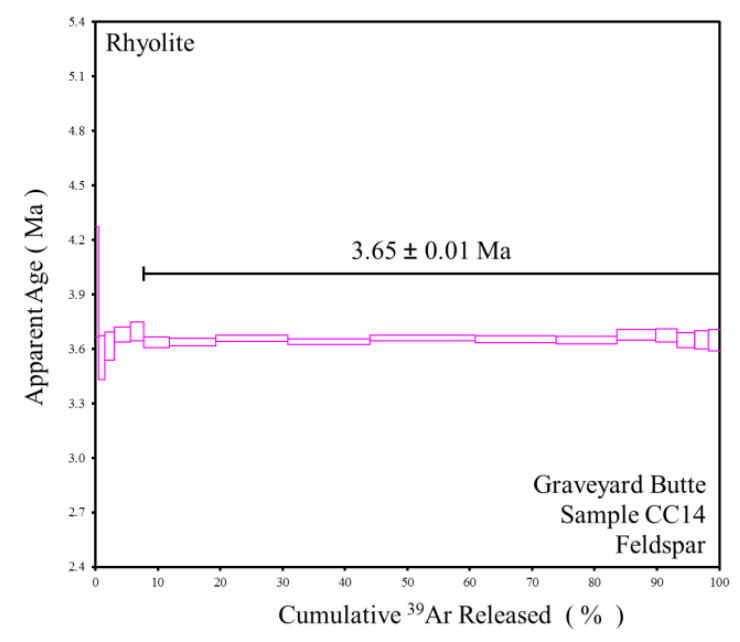

(B)

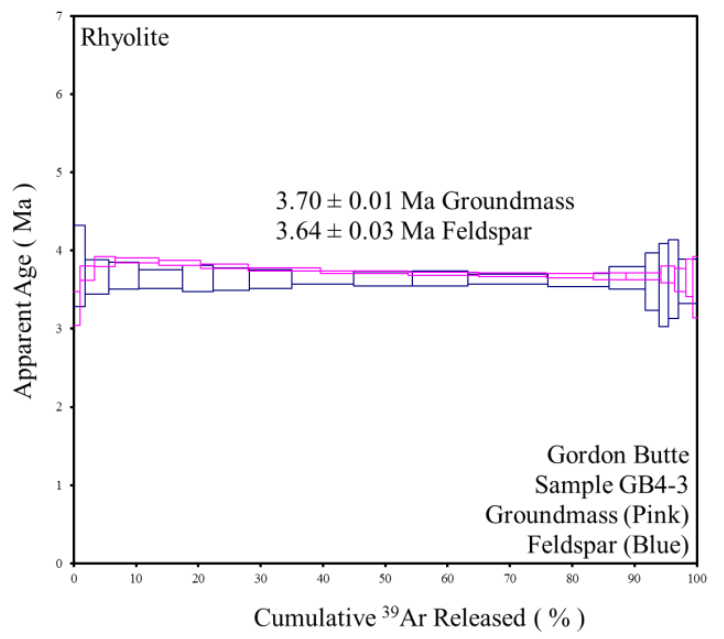

(D)

Figure 31. ${ }^{40} \mathrm{Ar} /{ }^{39} \mathrm{Ar}$ age spectra for $(\mathrm{A}, \mathrm{B})$ Graveyard Butte rhyolite, (C) Graveyard Butte andesite and (D) Gordon Butte rhyolite. Ages from the weighted plateau.

\section{B. ${ }^{87} \mathrm{Sr} /{ }^{86} \mathrm{Sr}$ Analyses}

Strontium analyses was conducted for two samples at Graveyard Butte-a

rhyolite and andesite. The Graveyard Butte quarry rhyolite sample X3 (feldspar) has an

${ }^{87} \mathrm{Sr} /{ }^{86} \mathrm{Sr}$ ratio of 0.703431 , with an error of 0.000011 . The Graveyard Butte andesite sample S12-6 from the southwestern portion of the White River canyon (groundmass) has an ${ }^{87} \mathrm{Sr} /{ }^{86} \mathrm{Sr}$ ratio of 0.703268 , with an error of 0.000011. 


\section{Discussion}

In summary, the field, petrographic, geochemical and isotopic analyses of Graveyard Butte with a comparison to Gordon Butte point to the following conclusions: (1) the rhyolite at Graveyard Butte is an endogenous dome (cryptodome) deforming the overlying andesite lavas and pyroclastic deposits; (2) the geochemical and mineralogical analyses of the rhyolitic rocks at Graveyard Butte and Gordon Butte's Badger Creek indicate they represent hot, dry, ferroan magmas similar to A-type or anorogenic rhyolites associated with intra-arc rifting or within plate tectonic settings; (3) a possible geotectonic setting is the opening of the intra-arc Cascade graben; and (4) the rhyolite of Gordon Butte's Upper Slopes rhyolite and the Graveyard Butte ash-flow tuff shows affinities with the younger volcanic arc magmas. The evidence is discussed in greater detail below.

\section{A. Field Evidence for an Endogenous Rhyolitic Dome and Flow at Graveyard Butte}

Clearly visible above the quarry and slightly to the west, the andesite outcrop is deformed. The andesite is faulted, with the A' block thrust over the A" (Figure 32). The movement is consistent with the upward rise of rhyolitic magma. 


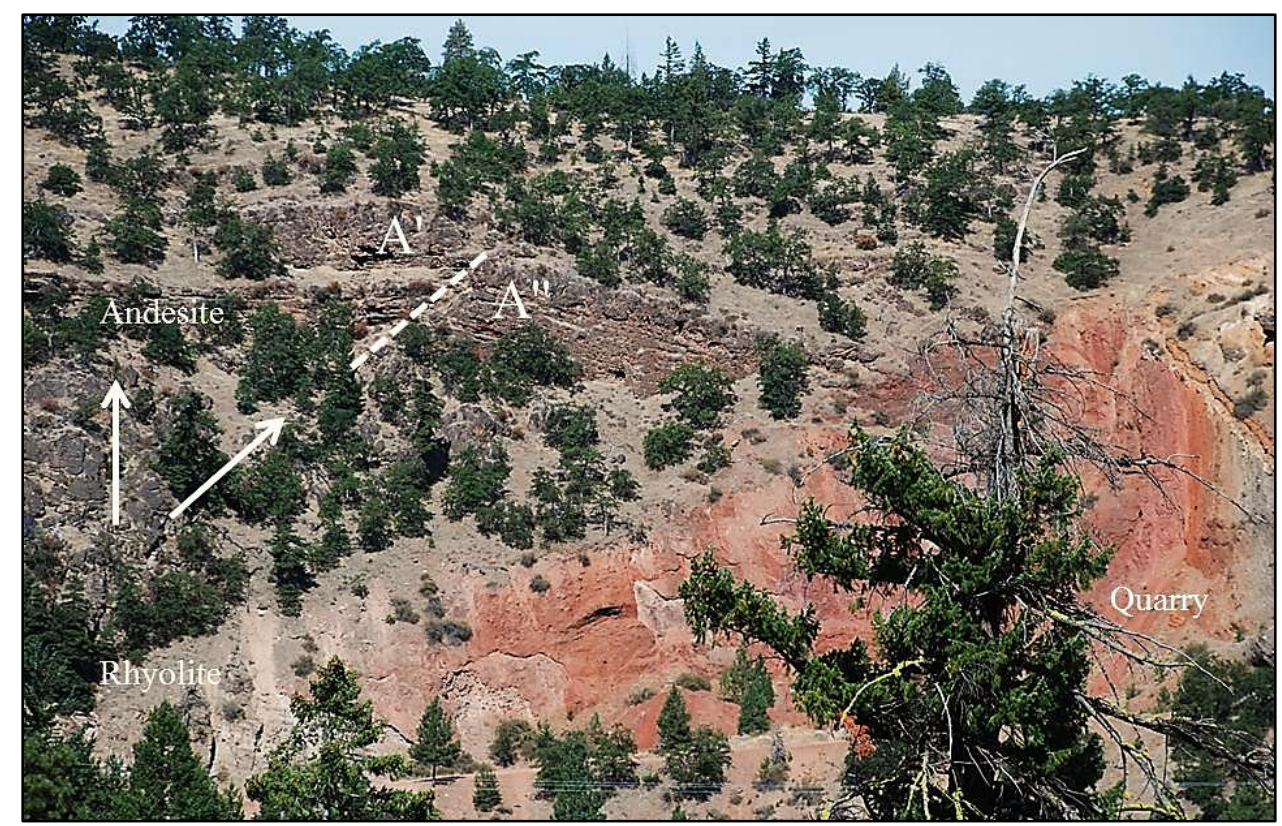

Figure 32. The upward rise of the rhyolitic magma (bottom left of image) produced the thrust fault in the overlying andesitic unit. As shown, the andesite of the A' block is thrust over the A".

As shown in Figure 32 and Figure 33, the rhyolite behind the red carapace is brecciated (lower center and lower left of images). Rhyolitic outcrop also includes coherent - albeit segmented flow (bottom far left of Figure 33, and Figure 34). 


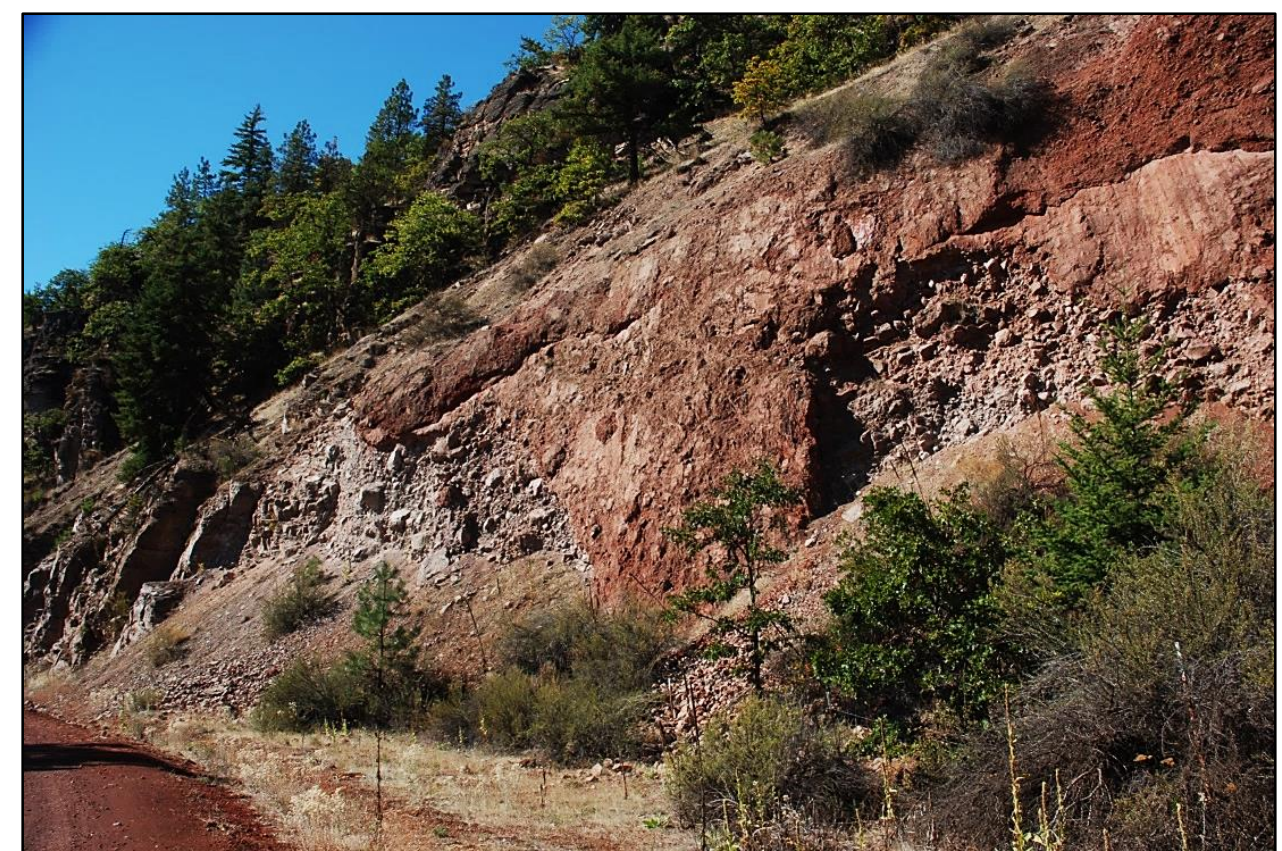

Figure 33. The rhyolite to the west of the Wasco County quarry is brecciated (as viewed behind the red carapace) but also includes a segmented, coherent flow (to the far left of image).

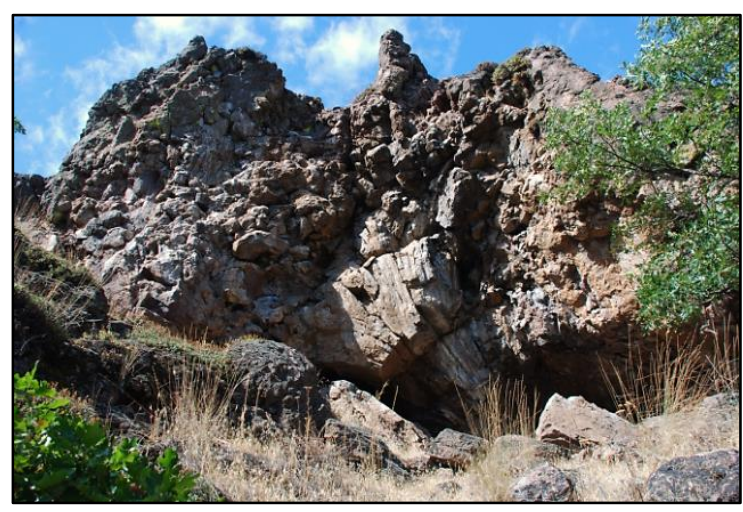

(A)

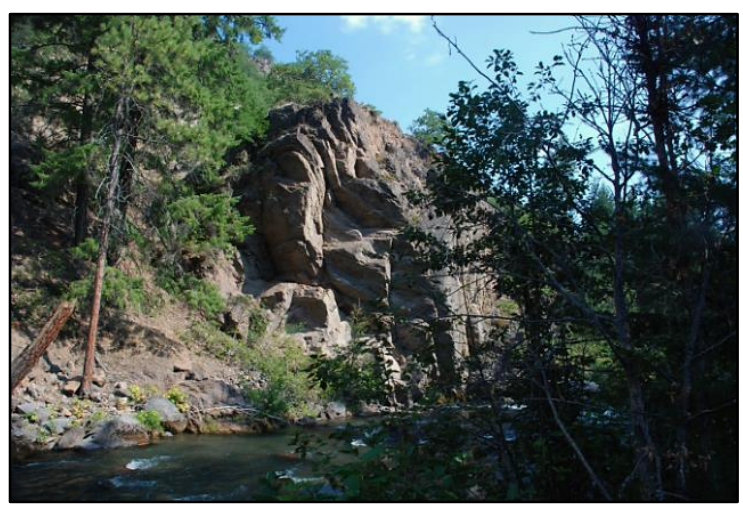

(B)

Figure 34. Examples of unbrecciated, coherent rhyolitic flow in the western canyon: (A) is a flow and doming feature (geochemical sample CC3); and (B) is flow-banded rhyolite.

Evidence of the doming effect is visible in the volcaniclastic debris of the Wasco County quarry (map unit Tt). An angular unconformity exists between the bottom-most unit (see Figure 11, Unit 7) and the strata above. A reasonable scenario for the formation of the unconformity is shown in Figure 35. Initially, the volcaniclastic debris of Unit 7 
would have been laid down relatively flat, given the uniform thickness of the unit. The rising magmatic intrusion would have bent the volcaniclastic package and tilted the entire unit upward by approximately $18^{\circ}$ (Figure 35). Subsequent volcanic events would have shed debris that was deposited along the slope of the tilted bed. The unit directly on top of Unit 7 (see Figure 11, Unit 6) pinches out upslope and thickens downslope, consistent with deposition on an incline. Moreover, Unit 6 comprises ash and lapilli, indicating that mild explosive activity could have accompanied a rhyolitic lava flow (Figure 34) after the dome was emplaced.

\section{Horizontal Deposition}

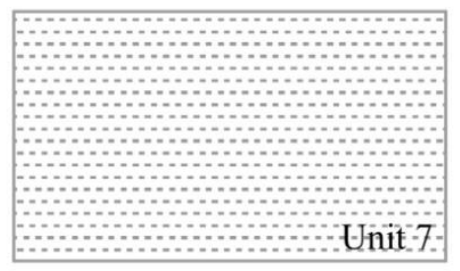

\section{Bend and Tilt $\left(\sim 18^{\circ}\right)$ Hydrothermal Fluids and Vapor}
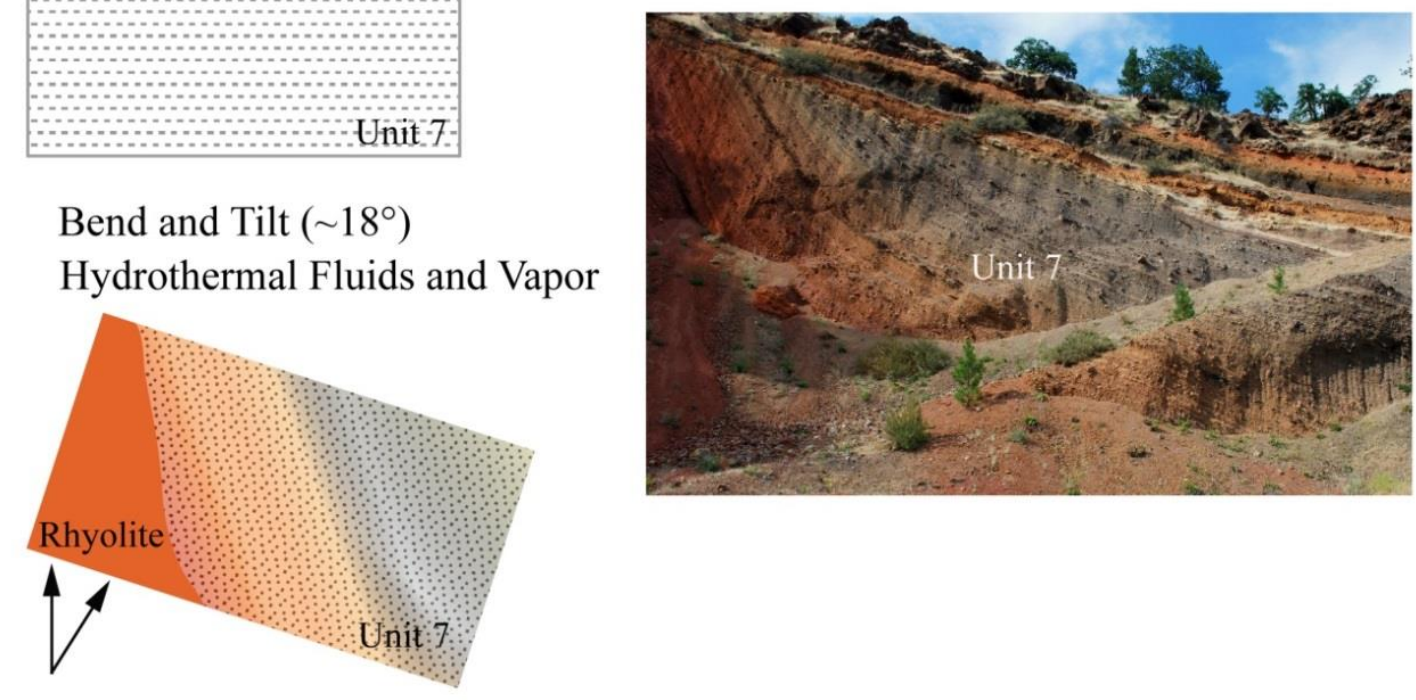

Figure 35. Deposition and evolution sequence of units at the Wasco County quarry, with focus on changes to Unit 7 . The initial position of the volcaniclastic unit is nearly horizontal. The rising rhyolitic magma bends and tilts the volcaniclastic package, with subsequent deposition of volcaniclastic debris down the inclined slope. Hydrothermal fluids and vapor produce the color gradations. The image to the right is provided for visual reference. 
One of the most visually-striking features in the quarry is the color change in Unit 7, from maroon to brick-red, orange, yellow, tan and gray (see Figure 35). As the magma was rising, it came into contact with meteoric water along its margins. The hydrothermal fluids and vapor interacted with the volcaniclastic layers of Unit 7 near the dome margin, producing the color gradations. The darkest red or maroon color is the contact with the intrusion (Figure 36). The maroon carapace itself is slightly indurated volcaniclastic material of the same type and composition as Unit 7 (see Appendix D. Geochemical Data, Table 4, samples S6-9 and X7b).

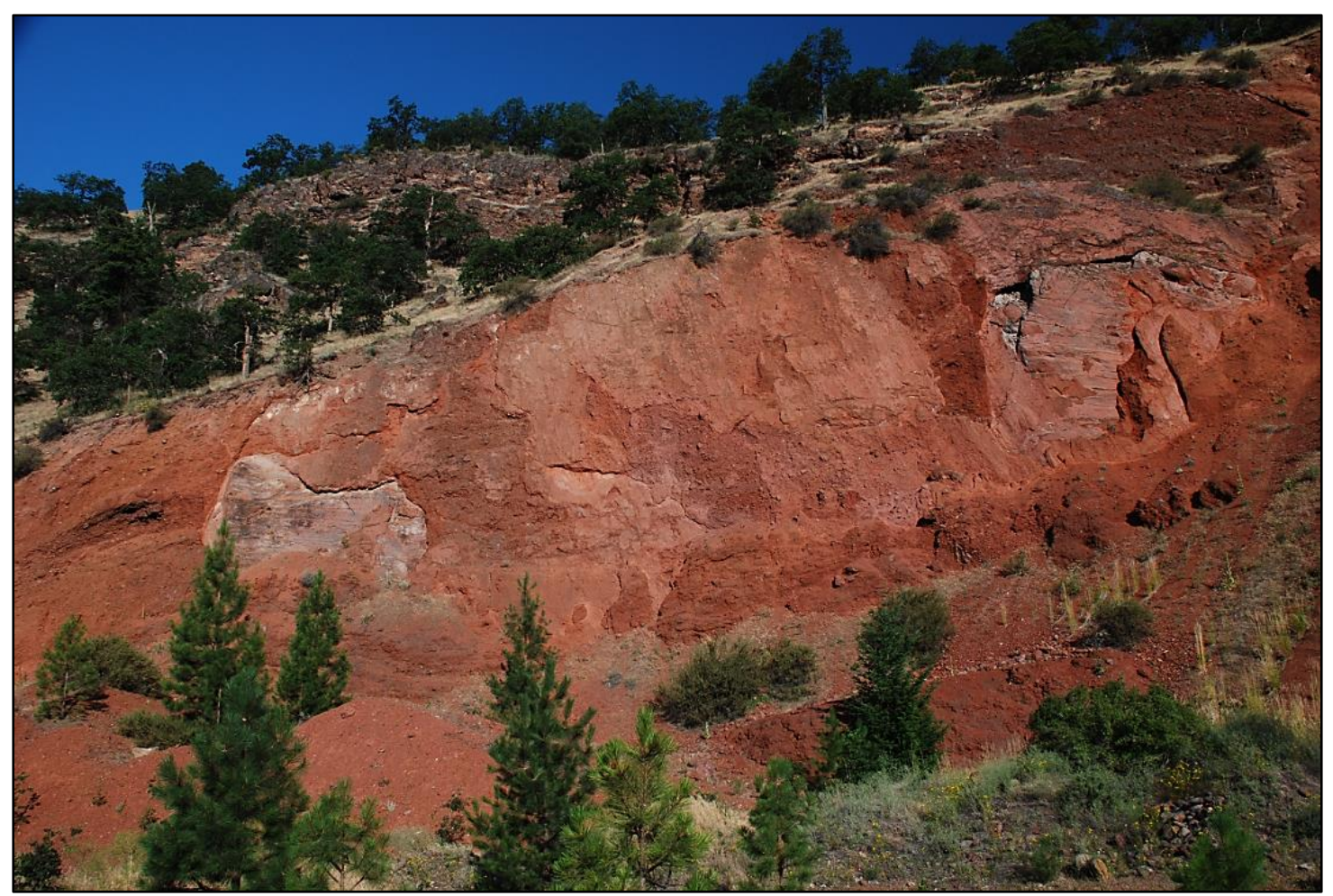

Figure 36. Dark-red or maroon is a color tracer for the contact between the rhyolitic intrusion and volcaniclastic debris of the quarry's Unit 7. The light-gray, brecciated rhyolite is visible in the upper right of the image behind the red-maroon carapace, and as the gray-pink surface in the middle left of the image. 
Finally, the timing of a later rhyolitic dome emplacement is consistent with the acquired age data. Sample X3 is flow-banded rhyolite from the quarry with a slightly younger (3.67 $\pm 0.01 \mathrm{Ma}$ ) age than the andesite outcrop (sample S12-6) from the southwestern portion of the White River canyon (3.86 $\pm 0.07 \mathrm{Ma}$ ) (see Figure 31$)$. This is what would be expected from the emplacement of an endogenous dome and flow subsequent to the eruption of andesitic lavas.

\section{B. Graveyard Butte and Badger Creek are A-Type Rhyolitic Magmas}

In the mid-1970s, a classification was established for characterizing the source of granitoid suites. Chappell and White published geochemical characteristics for those derived from igneous, meta-igneous (I-type) or metasedimentary sources (S-type) (Eby, 1990). The work was refined by White in 1979 to include a classification for the melted subducted oceanic crust or overlying mantle (M-type) (Eby, 1990). Loiselle and Wones added the A-type, linking geochemical affinities with the tectonic environment in which they are typically found (Eby, 1990).

The A-type granitoids - and their eruptive equivalents rhyolites, can be distinguished based on chemical characteristics (Eby, 1990). Compared to other rhyolites, A-types typically have high $\mathrm{FeO}_{\mathrm{t}} / \mathrm{MgO}$ and $\mathrm{K}_{2} \mathrm{O}+\mathrm{Na}_{2} \mathrm{O}$ and low $\mathrm{CaO}$ and $\mathrm{Al}_{2} \mathrm{O}_{3}$ (Eby, 1990), high abundances of HFSE (i.e., Zr, Nb, Y, cerium (Ce), Ti, but not Eu) (Dyhr et al., 2013; Eby, 1990), low Ba, Sr (Dyhr et al., 2013; Whalen, 1987), are waterpoor and halogen-rich (Eby, 1990). In primitive mantle normalized plots they generally show significant enrichment in cesium $(\mathrm{Cs})$ and rubidium $(\mathrm{Rb})$, significant depletion in 
$\mathrm{Ba}, \mathrm{Sr}, \mathrm{Eu}, \mathrm{Ti}$, and $\mathrm{P}$, no or minimal Nb, and tantalum (Ta) depletion (Eby, 1990). In chondrite normalized REE plots, the A-type signatures are variable, from relatively flat patterns with large negative Eu anomalies to more LREE enriched patterns with relatively small Eu anomalies. In most cases, the isotopic data indicate mantle involvement (Eby, 1990).

Minerals in A-type granitoids are commonly quartz+fayalite \pm Fe-rich pyroxenes \pm Fe oxides (Bonin, 2007; Eby, 1990). Small volumes of fluorine-bearing hydrous minerals can be present, such as amphibole and mica (Bonin, 2007; McCurry et al., 2008). As shown in Section V. Petrography of Graveyard Butte Units, the presence of Fe-clinopyroxene and fayalitic olivine along with the absence of hydrous phenocrysts in Graveyard Butte rhyolites are consistent with the A-type classification.

Most rhyolites at Graveyard Butte (with the exception of the ash-flow tuff) and Gordon Butte's Badger Creek are within the ranges proposed by Eby (1990) and Bonin (2007) for A-type granitoids generated in a Within Plate tectonic environment (Table 2). The ash-flow tuff and rhyolites of Gordon Butte's Upper Slopes share similarities in major oxides but differences appear in trace element concentrations. These rhyolites, with greater abundances of fluid-mobile trace elements and lesser amounts of HFSE, are more aligned with silicic magmas generated at or near a cooler, more fluid-rich subduction-generated volcanic arc. 
Table 2. Example of geochemical characteristics for A-type granitoids in samples with $\mathrm{SiO}_{2}$ of $\sim 70$ wt.\% (Bonin, 2007; Eby, 1990) compared to rhyolites at Graveyard and Gordon Buttes.

\begin{tabular}{|c|c|c|c|c|c|c|c|}
\hline $\begin{array}{l}\text { Expected } \\
\text { range for } \\
\text { A-type }\end{array}$ & $\begin{array}{c}\mathrm{SiO}_{2} \\
\text { (wt.\%) }\end{array}$ & $\begin{array}{c}\mathrm{Na}_{2} \mathrm{O}+ \\
\mathrm{K}_{2} \mathrm{O} \\
(\text { wt.\%) } \\
7-11 \%\end{array}$ & $\begin{array}{l}\mathrm{CaO} \\
\text { (wt.\%) } \\
<1.8 \%\end{array}$ & $\begin{array}{c}\mathrm{FeO} / \\
\mathrm{MgO} \\
\text { (wt.\%) } \\
8 \text { to } \\
80 \%\end{array}$ & $\begin{array}{c}\mathrm{Zr}+\mathrm{Nb}+ \\
\mathrm{Ce}+\mathrm{Y} \\
(\mathrm{ppm}) \\
>350 \mathrm{ppm}\end{array}$ & $\begin{array}{c}\begin{array}{c}\mathrm{Y}+\mathrm{Nb} \\
(\mathrm{ppm})\end{array} \\
>50 \mathrm{ppm} \text { for } \\
\text { Within Plate }\end{array}$ & $\begin{array}{c}\mathrm{Yb}+\mathrm{Ta} \\
(\mathrm{ppm}) \\
\\
>6 \mathrm{ppm} \\
\text { for Ocean } \\
\text { Ridge }\end{array}$ \\
\hline \multicolumn{8}{|c|}{ Graveyard Butte } \\
\hline $\mathrm{CC} 3$ & 72.6 & 9.0 & 1.0 & 20.8 & 678.2 & 83.9 & 7.3 \\
\hline $\mathrm{CC} 7$ & 73.0 & 9.0 & 1.0 & 29.5 & 672.9 & 84.3 & 7.3 \\
\hline S12_1L & 72.9 & 9.1 & 0.9 & 28.8 & 652.3 & 76.4 & 6.6 \\
\hline S12_2 & 72.8 & 9.0 & 0.8 & 14.4 & 653.7 & 79.9 & 6.7 \\
\hline S6_12 & 73.1 & 9.1 & 0.8 & 26.3 & 669.4 & 83.5 & 7.1 \\
\hline S6_13 & 73.2 & 9.0 & 0.8 & 18.1 & 669.7 & 85.2 & 7.3 \\
\hline WR13 & 73.2 & 9.2 & 0.6 & 31.4 & 661.1 & 81.2 & -- \\
\hline $\mathrm{X} 3$ & 73.0 & 9.1 & 1.0 & 35.8 & 674.9 & 82.8 & 7.0 \\
\hline \multicolumn{8}{|c|}{ Graveyard Butte Eastern Canyon } \\
\hline $\mathrm{CC} 13$ & 69.0 & 8.3 & 2.1 & 7.4 & 578.6 & 73.0 & 6.0 \\
\hline $\mathrm{CC} 14$ & 69.6 & 8.4 & 2.1 & 6.2 & 593.3 & 76.1 & 6.5 \\
\hline \multicolumn{8}{|c|}{ Gordon Butte Badger Creek } \\
\hline GB4_3 & 72.1 & 9.3 & 0.6 & 39.7 & 666.8 & 86.4 & 7.3 \\
\hline GB5a & 71.3 & 9.3 & 1.1 & 35.9 & 699.4 & 97.0 & 8.1 \\
\hline GB5b & 70.0 & 9.2 & 1.1 & 53.4 & 720.0 & 95.9 & 8.0 \\
\hline GB10 & 72.0 & 9.2 & 0.7 & 30.7 & 669.5 & 93.2 & -- \\
\hline \multicolumn{8}{|c|}{ Graveyard Butte Ash-flow Tuff } \\
\hline STR11_6 & 74.1 & 8.0 & 1.3 & 7.5 & 314.5 & 32.5 & -- \\
\hline \multicolumn{8}{|c|}{ Gordon Butte Upper Slopes } \\
\hline GB1_3 & 71.5 & 7.8 & 1.2 & 25.0 & 408.6 & 35.8 & 3.5 \\
\hline GB2 & 70.1 & 8.2 & 1.6 & 22.3 & 450.8 & 49.2 & 4.4 \\
\hline GB3 & 71.8 & 7.4 & 0.8 & 52.2 & 428.7 & 36.9 & 3.9 \\
\hline GB6 & 70.1 & 8.1 & 1.5 & 7.8 & 475.3 & 43.6 & 4.1 \\
\hline GB7 & 69.6 & 8.1 & 1.9 & 6.0 & 483.6 & 54.0 & 4.8 \\
\hline
\end{tabular}

The samples retain the same affinity groupings (e.g., Graveyard Butte-Badger Creek, Ash-flow Tuff-Upper Slopes) on multiple geochemical diagrams. As shown in Figure 37, the rhyolite of Graveyard Butte and Gordon Butte's Badger Creek are higher in alkalis, lower in $\mathrm{CaO}$, with greater abundance of HFSE and lower fluid-mobile trace 
elements. Gordon Butte's Upper Slopes and the ash-flow tuff of Graveyard Butte have greater concentrations of the more fluid-mobile elements. The two samples from Graveyard Butte's Eastern Canyon can plot with one group or the other, or between the two groups.
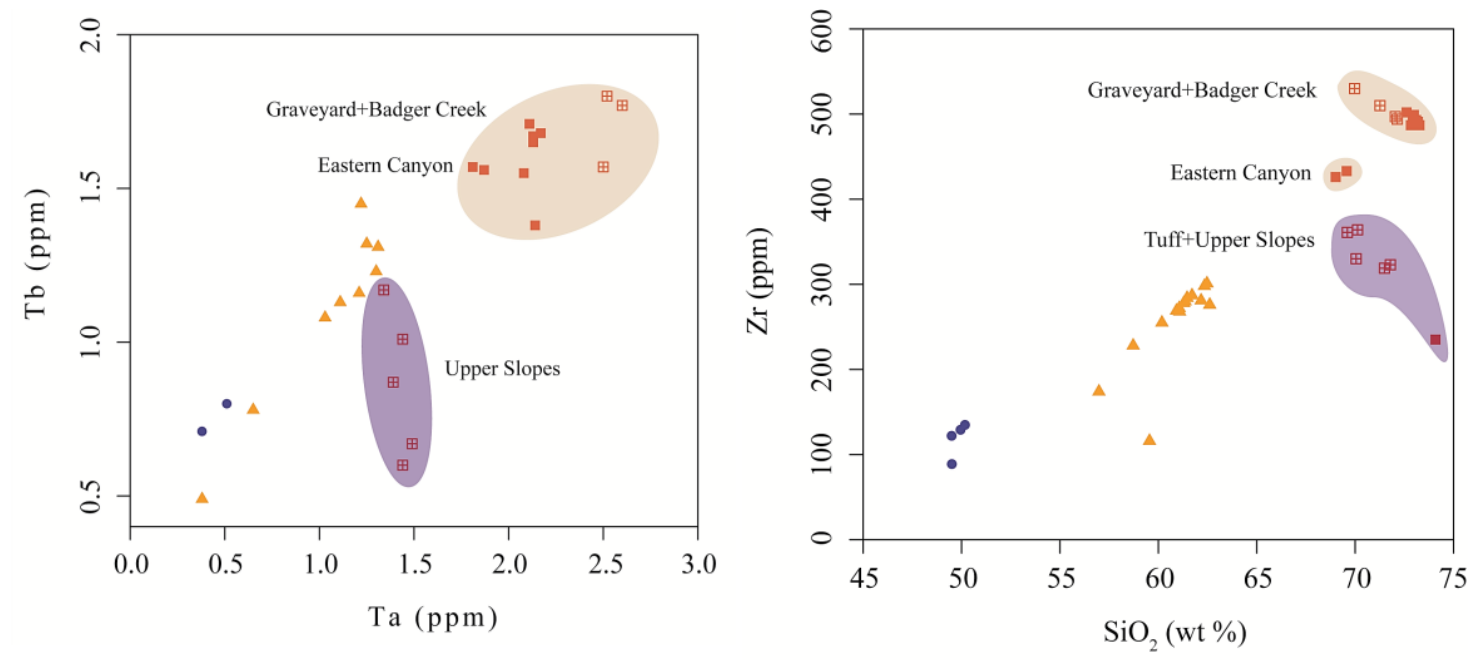

(A)
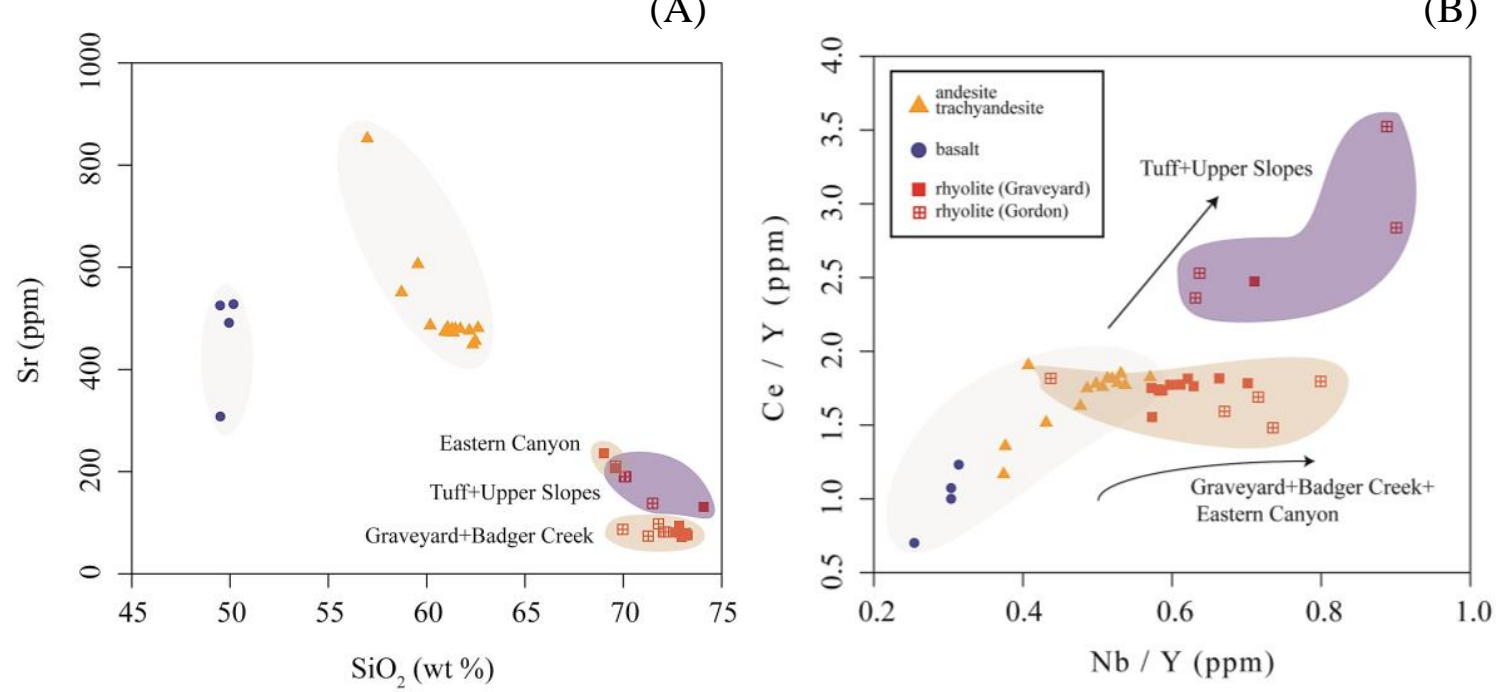

(C)

Figure 37. Geochemical diagrams demonstrate that Graveyard Butte and Badger Creek rhyolites have greater abundances of HFSE such as (A) Ta and Tb, and (B) Zr, are (C) lower in fluidmobile elements such as Sr, and (D) have a lower Ce concentration, than Graveyard Butte ashflow Tuff and rhyolites of Gordon Butte's Upper Slopes. 
In Figure 38, the samples with greater abundances of incompatible trace elements are from Graveyard Butte and Gordon Butte's Badger Creek. For comparison, the Graveyard Butte andesites are shown, along with dacite samples from Mill Creek Butte (6.2 $\pm 1.3 \mathrm{Ma}$ (Sherrod and Scott, 1995)). Mill Creek Butte is part of the Western Cascades-era subduction volcanism, located $\sim 25 \mathrm{~km}$ north of Gordon Butte. As demonstrated, the pattern for the volcanic arc is less enriched in trace elements with no Eu anomaly. The Gordon Butte Upper Slopes rhyolites, although showing an Eu anomaly, are similarly, less enriched.



Figure 38. Incompatible trace element diagram shows Graveyard Butte and Gordon Butte Badger Creek rhyolites with greater abundances compared to Gordon Butte Upper Slopes rhyolite and Mill Creek Butte, a Western Cascades-era subduction-generated dacite.

Lavas of Graveyard and Gordon Buttes can be further characterized using two indices: (1) an Fe-index that reflects magma differentiation history; and (2) a modified alkali-lime index reflecting abundance and composition of the feldspar (Frost and Frost, 
2008) (Figure 39). Magmas derived from subduction systems are generally characterized as calc-alkaline, magnesian, oxidized, wet and cool, with liquidus temperatures less than $850^{\circ} \mathrm{C}$ (Christiansen et al., 2008). Christiansen et al., (2008) contrasts this with the rhyolites of intraplate settings, which are alkaline to calc-alkaline, ferroan, reduced, dry, and hot $\left(830-1,050^{\circ} \mathrm{C}\right)$. Frost and Frost (2001) posit that the combination of ferroan with modified alkali lime index for alkali-calcic rhyolitic samples indicate an A-type or anorogenic granitoid, often associated with rifting tectonic environments or within plate settings. As shown in Figure 39, the Tuff and Upper Slopes plot within the ferroan field but are borderline calc-alkalic and alkali-calcic, whereas the rhyolite of Graveyard Butte and Badger Creek consistently plot in fields diagnostic of the A-types.

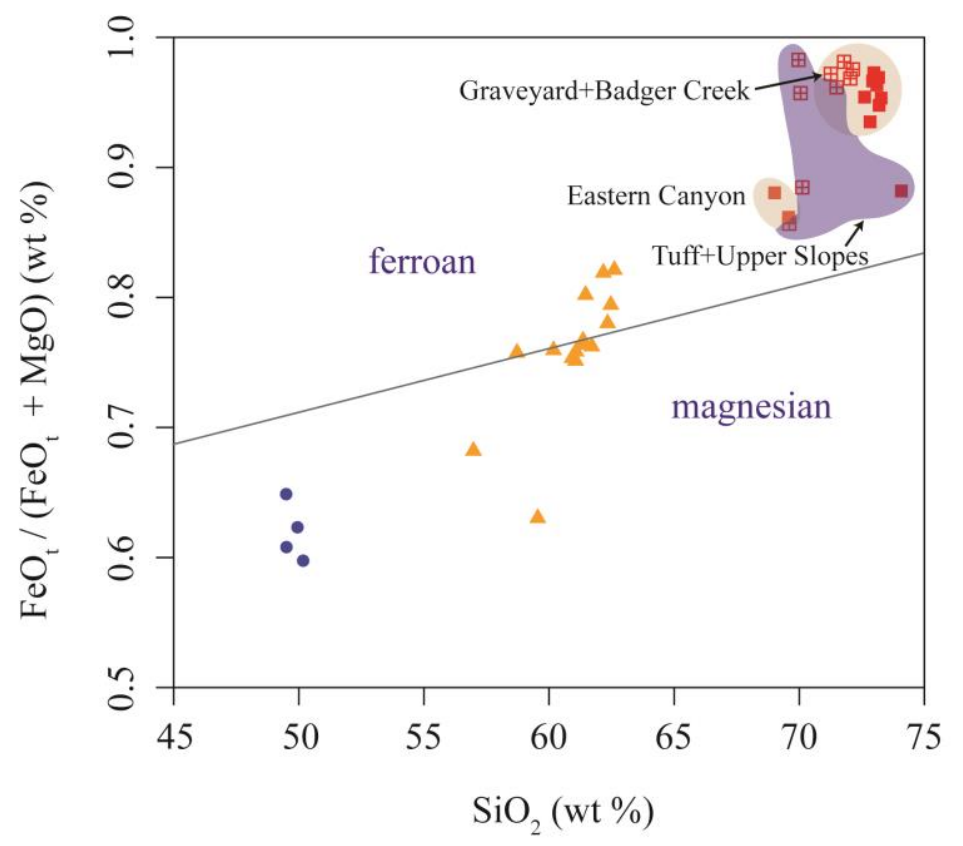

(A) 


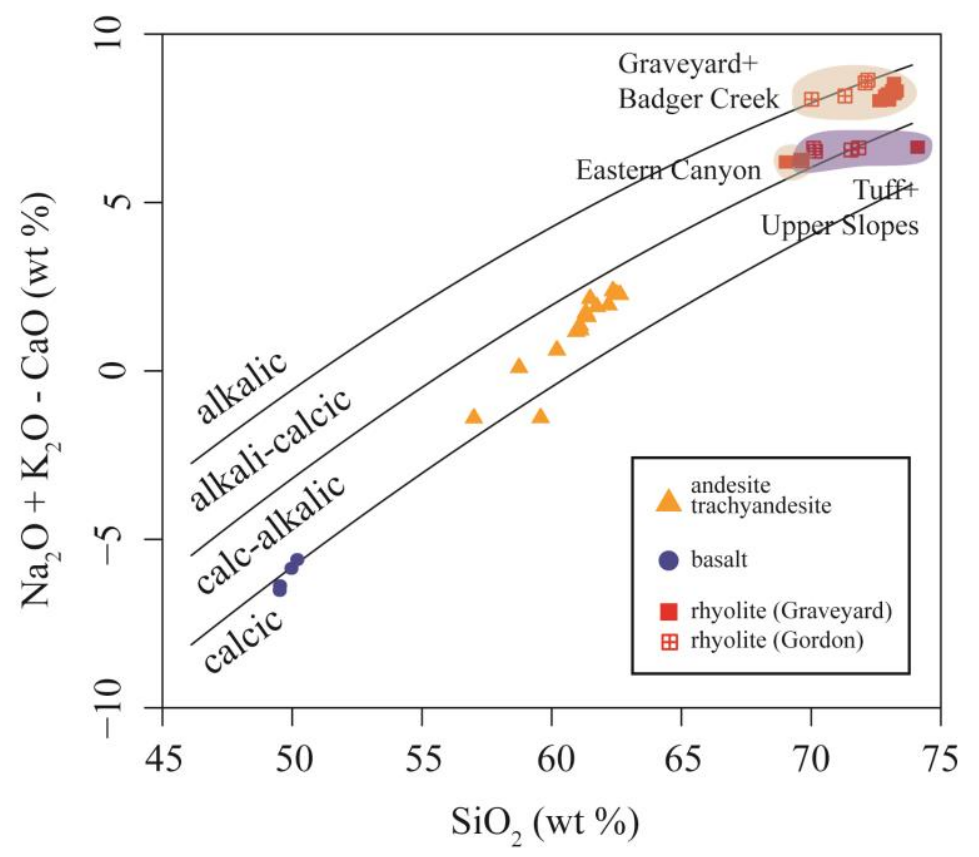

(B)

Figure 39. Lavas of Graveyard and Gordon Buttes characterized in (A) using the Fe-index, and (B) the modified alkali-lime index (fields after Frost and Frost, 2008). Rhyolites are ferroan and primarily alkalic-calcic, consistent with A-type granitoid geochemistry (Frost and Frost, 2001).

To broaden the scope of the geochemical comparison beyond Graveyard and Gordon Buttes, a dataset was assembled for archetypal lavas in and around the Pacific Northwest. Data was gathered for the silicic rocks of the Eastern Snake River Plain (southern Idaho), John Day and Clarno Formations as a proxy for within plate silicic volcanism (Bonnichsen et al., 1994, McClaughry et al., 2009); South Sister, Newberry as a proxy for young back-arc High Cascades lavas (Fierstein et al., 2011; MacLeod et al., 1995); Western Cascades as a proxy for ancestral subduction-related volcanism (du Bray and John, 2011); nearby dacites from Mount Hood as a proxy for modern-day subduction volcanics (Conrey, unpublished); and other Tygh Valley samples such as the rhyolites of Mutton Mountains (Johnson, 2011) (Figure 40). 


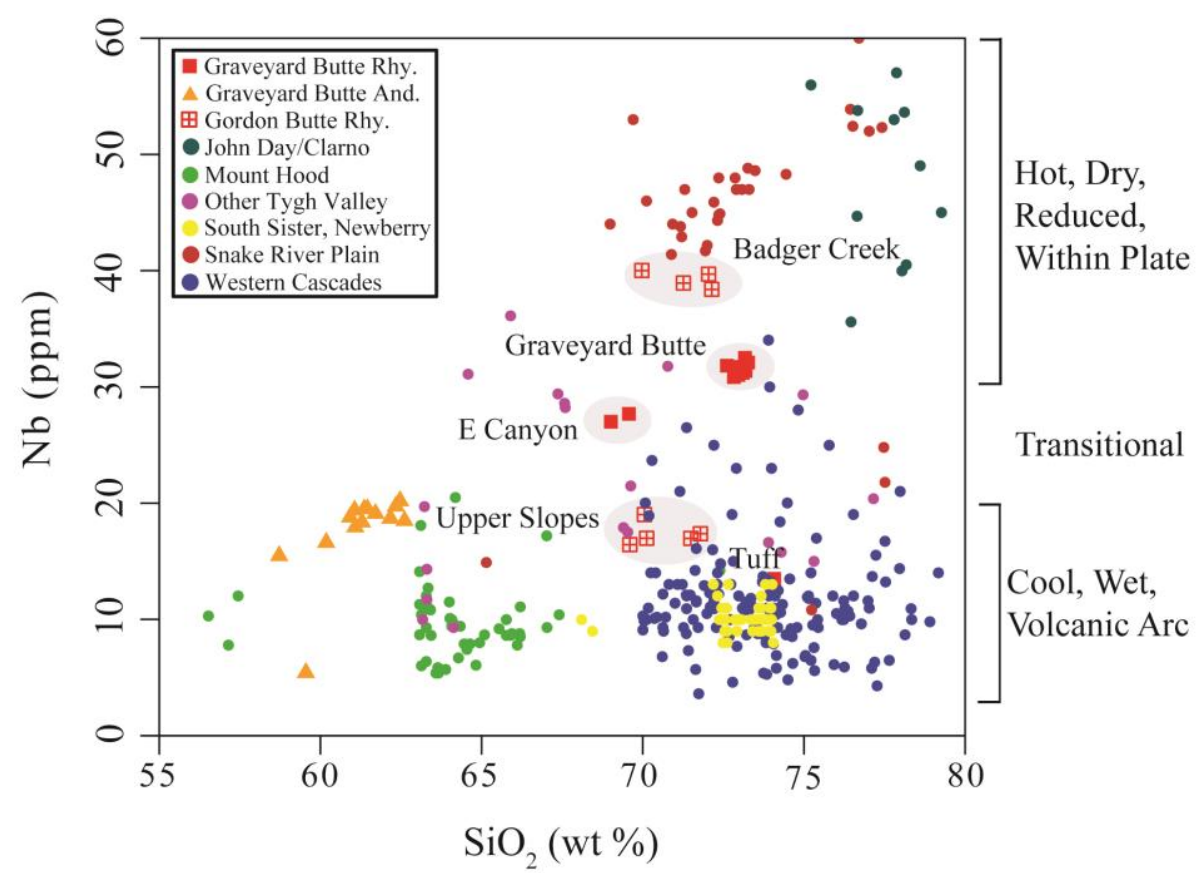

(A)

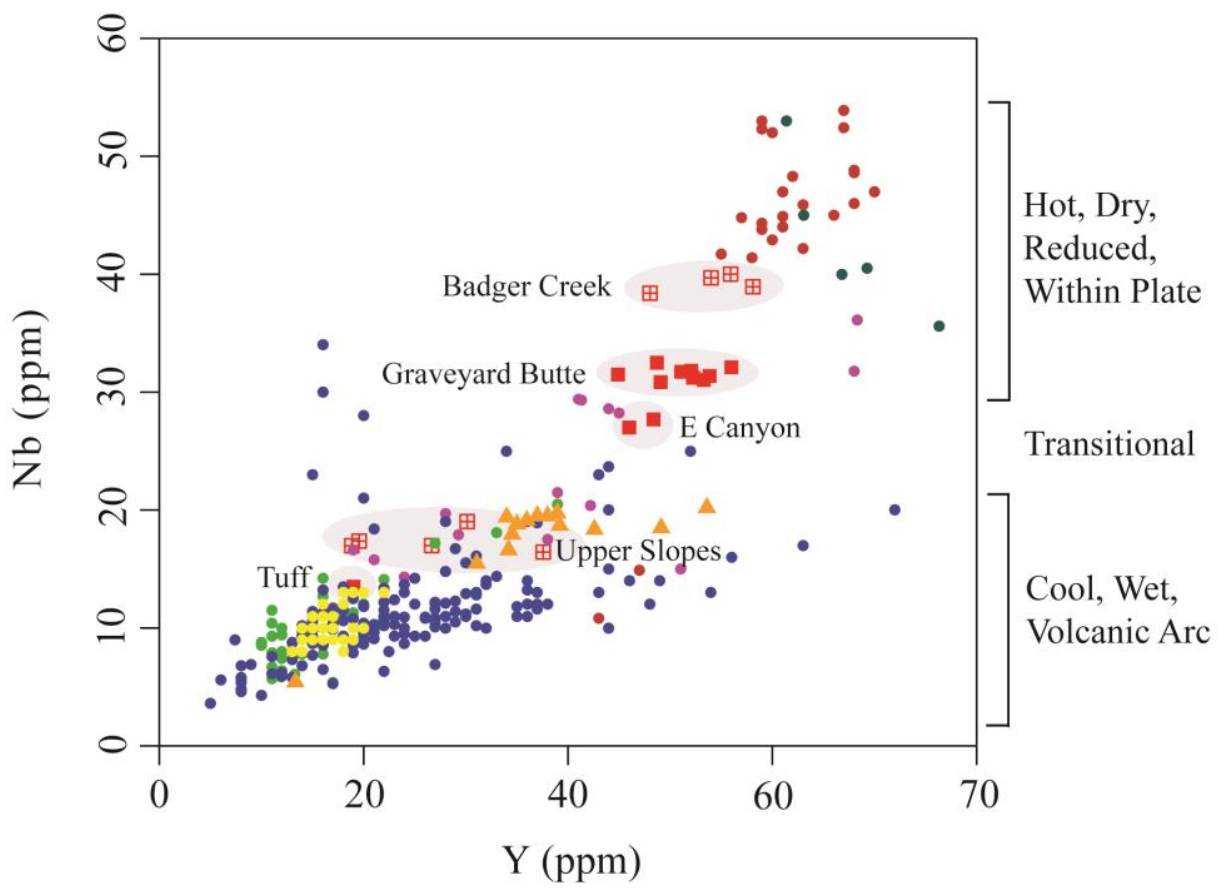

(B)

Figure 40. Comparison of regional rock samples to Graveyard Butte rhyolites and andesites, and Gordon Butte rhyolites, (A) $\mathrm{Nb}$ versus $\mathrm{SiO}_{2}$, and (B) Y versus $\mathrm{Nb}$. Data from Bonnichsen et al., 1994, McClaughry et al., 2009, Fierstein et al., 2011, MacLeod et al., 1995, du Bray and John, 
2011, Conrey, unpublished, Johnson, 2011 and Appendix D. Geochemical Data, Table 3, Table 4, Table 5, Table 6, and Table 7).

The results show geochemical affinities among lavas generated in specific settings. The Graveyard Butte ash-flow Tuff and Gordon Butte Upper Slopes flow show an affinity with South Sister, Newberry, High Cascades and Western Cascades magma generation settings. The rhyolite from Badger Creek is similar to Eastern Snake River Plain and Graveyard Butte rhyolites show some affinities to the Eastern Snake River Plain although some Graveyard Butte rhyolites are transitional, between the Eastern Snake River Plain and Western Cascades proxies (Figure 40).

The Eastern Snake River Plain is characterized by McCurry et al., (2008) as a post-hotspot, basalt-dominated volcanic field intruded, interlayered or overlain by cryptodomes, domes and flows of intermediate lavas and high-silica A-type rhyolite. McCurry et al.,'s (2008) physical model for the generation of rhyolite in this setting is the fractional crystallization of a basaltic trachyandesite parent magma $\left(\sim 55 \% \mathrm{SiO}_{2}\right)$ with only a trace $(<1 \%)$ of crustal assimilation (McCurry et al., 2008). The lack of crustal assimilation suggests a relatively rapid transit of magma to the surface.

Graveyard Butte rhyolite sample X3 has an ${ }^{87} \mathrm{Sr} /{ }^{86} \mathrm{Sr}$ ratio of 0.703431 and the andesite sample has an ${ }^{87} \mathrm{Sr} /{ }^{86} \mathrm{Sr}$ ratio of 0.703268 . Similar ratios are found south of Graveyard Butte at Mt. Jefferson, where ratios of rhyodacites are $0.70325-0.70343$ (Conrey, et al., 2001). Conrey, et al. (2001) indicate that the rhyodacite with the ${ }^{87} \mathrm{Sr} /$ ${ }^{86} \mathrm{Sr}$ ratios around 0.7033 are likely generated through partial melting of the crust at depths of $25-35 \mathrm{~km}$ and temperatures of $850-1100^{\circ} \mathrm{C}$. To obtain these temperatures, 
Conrey, et al., (2001) suggest that intra-arc rifting played a major role in developing a hot mafic underplate; rifting could have also provided a more rapid pathway for magma to the surface.

\section{Tectonic Connection}

A-type granitoids/rhyolites are associated with extensional tectonic environments such as rift zones (back arc, island arc) or within plate (hot spot) continental settings (Eby, 1990; Frost et al., 2001). As shown in Figure 41, Gordon Butte lies just to the east of the Hood River fault, which was active by at least 2.9 Ma (Conrey et al., 1996). South of the Hood River fault is the Warm Springs fault is a 30-km-wide zone of mostly westdipping, north-striking normal faults that offset early Pleistocene, Pliocene, and Miocene volcanic rocks and sediments (Personius et al., 2003). To the south of the Warm Springs fault, is the Green Ridge fault that offsets upper Miocene $(5.27 \pm 0.04 \mathrm{Ma})$ volcanic rocks of the Deschutes Formation (Personius et al., 2003). The timing of the activity along these faults (5.27-2.9 Ma) encompasses the time period for volcanic activity at the

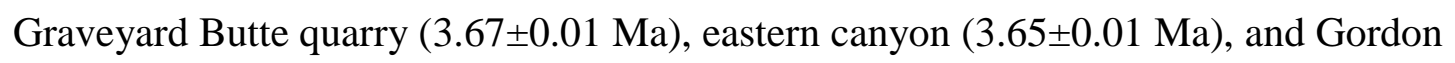
Butte's Badger Creek (3.64 $\pm 0.03 \mathrm{Ma})$. A possible geotectonic framework for the generation of these $~ 3.6$ Ma rhyolite lavas is the northward-propagating intra-arc rift of the Oregon Cascades. 




Figure 41. Regional map of central and northern Oregon with folds (solid green lines) and faults (dotted lines) (U.S. Geological Survey and others, 2006). Basemap by ESRI. Map scale 1:750,000. 


\section{Conclusions}

The Tygh Valley area is largely undifferentiated, in part due to the voluminous $(\sim 2.77 \mathrm{Ma})$ basalt flows that created the relatively flat expanses of present-day Juniper Flat and Smock Prairie, hiding what lies beneath. Geologic maps have identified units at Graveyard and Gordon Buttes as Tertiary (7-2 my) andesitic to rhyolitic dome fields, near-vent breccia and pyroclastic rocks (du Bray and John, 2011; Sherrod and Smith, 2000). This research builds on that work with new insights into the geologic evolution of the area.

Two different types of rhyolites can be distinguished at Graveyard and Gordon Buttes. One type is represented by the Graveyard Butte ash-flow tuff and rhyolites of Gordon Butte's upper slopes that are lower in $\mathrm{Nb}$ (13-19 ppm) and Ta (1.34-1.49 ppm) and richer in $\mathrm{Sr}(97-211 \mathrm{ppm})$. Generation of these magmas is consistent with a volcanic arc setting. The second is the rhyolite lava flows at Graveyard Butte and at Gordon Butte's Badger Creek (Nb from 30-40 ppm; Ta from 2.1-2.6 ppm; Sr from 72-94 ppm). Incompatible trace-element-enriched compositions and mineralogical indicators show that these magmas are A-type rhyolites that are likely generated in an extensional setting. A possible geotectonic framework for generation of these rhyolite lavas is the northward propagating intra-arc rift of the Oregon Cascades. 


\section{References}

Bachmann, O., Miller, C.F., de Silva, S.L., 2007, The volcanic-plutonic connection as a stage for understanding crustal magmatism: Journal of Volcanology and Geothermal Research, v. 167, p. 1-23.

Beebee, R.A., O’Connor, J.E., Grant, G.E., 2002, Geology and geomorphology of the lower Deschutes River canyon, Oregon, in Moore, G.W., ed., Field guide to geologic processes in Cascadia: Oregon Department of Geology and Mineral Industries, Special Paper 36.

Bonnichsen, B., Leeman, W.P., Bernt, J., Godchaux, M.M., Jenks, M.D., 1994, Analyzed rocks from the Sheep Creek 30x60 minute quadrangle, Owyhee and Twin Falls counties, southwestern Idaho: Idaho Geological Survey, Technical Report 94-5, 1 sheet.

Bonin, B., 2007, A-type granites and related rocks: Evolution of a concept, problems and prospects: Lithos, v. 97, p. 1-29.

Cameron, K. A., and Pringle, P., 1987, A detailed chronology of the most recent major eruptive period at Mount Hood, Oregon: Geological Society of America Bulletin, vol. 99 , p. 845-851.

Chaussard, E., Amelung, F., 2013, Regional controls on magma ascent and storage in volcanic arcs: Geochemistry, Geophysics, Geosystems, v. 15, p. 1407-1418.

Cheney, E.S., Hayman, N.W., 2007, Regional Tertiary sequence stratigraphy and structure on the eastern flank of the central Cascade Range, in Stelling, P., Tucker, D.S, eds., Floods, faults and fire: Geological field trips in Washington State and southwest British Columbia: Geological Society of America, Field Guide 9, p. 179-208.

Christiansen, E. H., McCurry, M., 2008, Contrasting origins of Cenozoic silicic volcanic rocks from the western Cordillera of the United States: Bulletin of Volcanology, v. 70, p. 251-267.

Conrey, R.M., 1985, Volcanic stratigraphy of the Deschutes Formation, Green Ridge to Fly Creek, north-central Oregon [MS Thesis]: Corvallis, Oregon State University, $365 \mathrm{p}$.

Conrey, R.M., Sherrod, D.R., Uto, K., Uchiumi S., 1996, Potassium-argon ages from Mount Hood area of Cascade Range, northern Oregon: Isochron/West, v. 63, p. 10-20.

Conrey, R.M., Taylor, E.M., Donnelly-Nolan, J.M., Sherrod, D.R., 2002, North-central Oregon Cascades: Exploring petrologic and tectonic intimacy in a propagating intra-arc rift, in Moore, G.W., ed., Field guide to geologic processes in Cascadia: 
Oregon Department of Geology and Mineral Industries, Special Paper 36, p. 4790.

Conrey, R., Grunder, A., Schmidt, M., 2004, State of the Cascade arc: stratocone persistence, mafic lava shields, and pyroclastic volcanism associated with intraarc rift propagation: State of Oregon, Oregon Department of Geology and Mineral Industries, Open File Report O-04-04.

Conrey, R.M., Hooper, P.R., Larson, P.B., Chesley, J., and Ruiz, J., 2001, Trace element and isotopic evidence for two types of crustal melting beneath a High Cascade volcanic center, Mt. Jefferson, Oregon: Contributions to Mineral Petrology, v. 141, p. $710-732$.

Cox, K. G., Bell, J. D., Pankhurst, R. J., 1979, The interpretation of igneous rocks: London, George Allen and Unwin, $450 \mathrm{p}$.

Darr, C.M., 2006, Magma chamber processes over the past 475,000 years at Mount Hood, Oregon: Insights from crystal zoning and crystal size distribution studies [M.S. Thesis]: Corvallis, Oregon State University, 154 p.

DeRoo, T.G., 2006, Recent geologic history of the upper White River valley, Oregon: Oregon Geology, vol. 67, no. 1.

du Bray, E.A., John, D.A., 2011, Petrologic, tectonic, and metallogenic evolution of the ancestral Cascades magmatic arc, Washington, Oregon, and northern California: Geosphere, v. 7, n. 5, p. 1102-1133.

Dyhr, C.T., Holm, P.M., Llambías, E.J., 2013, Geochemical constraints on the relationship between the Miocene-Pliocene volcanism and tectonics in the Palaoco and Fortunoso volcanic fields, Mendoza Region, Argentina: New insights from ${ }^{40} \mathrm{Ar} /{ }^{39} \mathrm{Ar}$ dating, $\mathrm{Sr}-\mathrm{Nb}-\mathrm{Pb}$ isotopes and trace elements: Journal of Volcanology and Geothermal Research, v. 266, p. 50-68.

Eby, G.N., 1990, The A-type granitoids: A review of their occurrence and chemical characteristics and speculations on their petrogenesis: Lithos, v. 26, p. 115-134.

Ewart, A., 1982, The mineralogy and petrology of Tertiary-recent orogenic volcanic rocks: with special reference to the andesitic-basaltic compositional range; p. 2595 in Thorp, R.S., ed., Andesites: Orogenic andesites and related rocks: New York, John Wiley and Sons, 724 p.

Farooqui, S.M., Beaulieu, J.D., Bunker, R.C., Stensland, D.E., and Thoms, R.E., 1981, Dalles Group: Neogene formations overlying the Columbia River Basalt Group in north-central Oregon: Oregon Geology, v. 43, p. 16. 
Fierstein, J., Hildreth, W., Calvert, A.T., 2011, Eruptive history of South Sister, Oregon Cascades: Journal of Volcanology and Geothermal Research, v. 207, p. 145-179.

Ford, M., 2011, Rhyolitic magmatism of the High Lava Plains and adjacent northwest Basin and Range, Oregon: Implications for the evolution of continental crust [Ph.D Dissertation]: Corvallis, Oregon State University, 331 p.

Frost, B.R., Arculus, R.J., Barnes, C.G., Collins, W.J., Ellis, D.J., Frost, C.D., 2001, A geochemical classification of granitic rocks: Journal of Petrology, v. 42, p. 2033 2048.

Frost, B.R., Frost, C.D., 2008, A geochemical classification for feldspathic igneous rocks: Journal of Petrology, v. 49, p. 1955-1969.

Frost, B.R., Frost, C.D., 2011, On ferroan (A-type) granitoids: their compositional variability and modes of origin: Journal of Petrology, v. 52, p. 39-53.

Gray, L.B., Sherrod, D.R., Conrey, R.M., 1996, Potassium-argon ages from the northern Oregon Cascade Range: Isochron/West, v. 63, p. 21-28.

Heiken, G., Wohletz, K., 1987, Tephra deposits associated with silicic domes and lava flows: Geological Society of America, Special Papers 212, p. 55-76

Hildreth, W., Fierstein, J., Calvert, A.T., 2012, Geologic map of Three Sisters volcanic cluster, Cascade Range, Oregon: U.S. Geological Survey, Scientific Investigations Map 3186, pamphlet, 107 p.

Hildreth, W., Lanphere, M.A., 1994, Potassium-argon geochronology of a basaltandesite-dacite arc system: the Mount Adams volcanic field, Cascade Range of southern Washington: Geological Society of America Bulletin, v. 106, p. 14131429.

Hildreth, W., 2007, Quaternary magmatism in the Cascades-geologic perspectives: U.S. Geological Survey, Professional Paper 1744, 125 p.

Hildreth, W., Moorbath, S., 1988, Crustal contributions to arc magmatism in the Andes of Central Chile: Contributions to Mineralogy and Petrology, v. 98, p. 455-499.

Janoušek, V., Farrow, C. M., Erban, V., 2006, Interpretation of whole-rock geochemical data in igneous geochemistry: Introducing Geochemical Data Toolkit (GCDkit): Journal of Petrology, v. 47, n. 6, p. 1255-1259.

Johnson, A.K., 2011, Dextral shear and north-directed crustal shortening defines the transition between extensional and contractional provinces in north-central Oregon [MS Thesis]: Corvallis, Oregon State University, 90 p. 
Kent, A.J.R., Darr, C., Koleszar, A.M., Salisbury, M.J., Cooper, K.M., 2010, Preferential eruption of andesitic magmas through recharge filtering: Nature Geoscience, v. 3, p. 631-636.

Karlstrom, L., Dufek, J., Manga, M., 2009, Organization of volcanic plumbing through magmatic lensing by magma chambers and volcanic loads: Journal of Geophysical Research, v. 114, n. B10, 16 p.

Koleszar, A.M., Kent, A.J.R., Wallace, P.J., Scott, W.E., 2012, Controls on long-term low explosivity at andesitic arc volcanoes: Insights from Mount Hood, Oregon: Journal of Volcanology and Geothermal Research, v. 219-220, p. 1-92.

Koppers, A.A.P., $1998,{ }^{40} \mathrm{Ar} /{ }^{39} \mathrm{Ar}$ geochronology and isotope geochemistry of the West Pacific seamount province: Implications for absolute Pacific plate motion and the motion of hotspots [PhD Dissertation]: The Netherlands, Vrije Universiteit Amsterdam, $263 \mathrm{p}$.

Lamson, K., Clark, J.S., 2004, White River watershed assessment: The Dalles, Wasco County Soil and Water Conservation District, 116 p.

LeBas, M.J., LeMaitre, R.W., Streckeisen, A., Zanettin, B., 1986, A chemical classification of volcanic rocks based on the total alkali-silica diagram: Journal of Petrology, v. 27, p. 745-750.

MacLeod, N.S., Sherrod, D.R., Chitwood, L.A., Jensen, R.A., 1995, Geologic map of Newberry Volcano, Deschutes, Klamath, and Lake Counties, Oregon: U.S. Geological Survey, Miscellaneous Investigations Series Map I-2455, map scale 1:62,500, 2 sheets, pamphlet $23 \mathrm{p}$.

Mathez, E.A., VanTongeren, J.A., Schweitzer, J., 2013, On the relationships between the Bushveld Complex and its felsic roof rocks, part 1: petrogenesis of Rooiberg and related felsites: Contributions to Mineralogy and Petrology, v. 155, p. 435-449.

McClaughry, J.D., Ferns, M.L., Streck, M.J., Patridge, K.A., Gordon, C.L., 2009, Paleogene calderas of central and eastern Oregon: Eruptive sources of widespread tuffs in the John Day and Clarno Formations: Geological Society of America, Field Guides, v. 15, p. 407-434.

McCurry, M., Hayden, K.P., Morse, L.H., 2008, Genesis of post-hotspot, A-type rhyolite of the Eastern Snake River Plain volcanic field by extreme fractional crystallization of olivine tholeiite: Bulletin of Volcanology, v. 30, p. 361-383.

McDonough, W.F., Sun, S.S., 1995, Composition of the Earth: Chemical Geology, v. 120 , p. 223-253. 
Miyashiro, A., 1974, Volcanic rock series in island arcs and active continental margins: American Journal of Science, v. 274, p. 321-355.

Mustoe, G.E., Leopold, E.B., 2014, Paleobotanical evidence for the post-Miocene uplift of the Cascade Range: Canadian Journal of Earth Sciences, v. 51 n. 8, p. 809824.

National Oceanic and Atmospheric Administration-National Weather Service Forecast Office, 2014, Local Climate Data from Portland Airport, available at http://www.wrh.noaa.gov/pqr/pdxclimate/pg78.pdf, accessed June 21, 2014.

Personius, S.F., Dart, R.L., Bradley, L., Haller, K.M., 2003, Map and data for Quaternary faults and folds in Oregon: U.S. Geological Survey, Open File Report 03-095, $556 \mathrm{p}$.

Pirot, R., 2010, Initiation zone characterization of debris flows in November, 2006, Mount Hood, Oregon [MS Thesis]: Portland, Portland State University, 179 p.

Porritt, R.W., Allen, R.M., Boyarko, D.C., Brudzinski, M.R., 2011, Investigation of Cascadia segmentation with ambient noise tomography: Earth and Planetary Science Letters, v. 309, n. 1-2, p. 67-76.

Priest, G.R., 1990, Volcanic and tectonic evolution of the Cascade volcanic arc, central Oregon: Journal of Geophysical Research, v. 95, n. B12, p. 19583-19599.

Reed, S.J.B., 2005, Electron microprobe analysis and scanning electron microscopy in Geology, second edition: New York, Cambridge University Press, 192 p.

Scott, W.E., Gardner, C.A., Tilling, R.I., and Lanphere, M.A., 1997, Geologic history of Mount Hood volcano, Oregon: A field-trip guidebook: U.S. Geological Survey, Open-File Report, v. 97, 38 p.

Shaver, F.A., Rose, A.P., Steele, R.F., Adams, A.E., 1905, An illustrated history of central Oregon: Spokane, Western Historical Publishing Company.

Sherrod, D.R., Scott, W.E., 1995, Preliminary geologic map of the Mount Hood 30- by 60-Minute Quadrangle, northern Cascade Range, Oregon: U.S. Geological Survey, Open-File Report 95-219, 35 p.

Sherrod, D.R., Smith, J.G., 2000, Geologic map of the upper Eocene to Holocene volcanic and related rocks of the Cascade Range, Oregon: U.S. Geological Survey, pamphlet to accompany IMAP-2569, $17 \mathrm{p}$.

Sherrod, D.R., Taylor, E.M., Ferns, M.L., Scott, W.E., Conrey, R.M., Smith, G.A., 2004, Geologic map of the Bend 30- × 60-Minute Quadrangle, central Oregon: U.S. Geological Survey, pamphlet to accompany Geologic Investigations Series I2683, 48 p. 
Smith, G.A., 1986, Stratigraphy, sedimentology, and petrology of Neogene rocks in the Deschutes Basin, central Oregon: A record of continental margin volcanism and its influence on fluvial sedimentation in an arc-adjacent basin [PhD Dissertation]: Corvallis, Oregon State University, 464 p.

Soil Survey Staff, undated, Official Soil Series Descriptions [Wamic Series]: United States Department of Agriculture, Natural Resources Conservation Service, available at http://soils.usda.gov/technical/classification/osd/index.html, accessed June 21, 2014.

Streck, M.J., Grunder, A.L., 2008, Phenocryst-poor rhyolites of bimodal, tholeiitic provinces: the Rattlesnake tuff and implications for mush extraction models: Bulletin of Volcanology, v. 70, p. 385-401.

Sun, S.-S., McDonough, W.F., 1989, Chemical and isotopic systematics of oceanic basalts: Implications for mantle composition and processes, in Saunders, A.D., Norry, M.J., eds., Magmatism in ocean basins: Geologic Society of London, Special Publications, v. 42, p. 313-345.

Tanton, L.T.E., Grove, T.L., Donnelly-Nolan, J., 2001, Hot, shallow mantle melting under the Cascades volcanic arc: Geology, v. 29, no. 7, p. 631-634.

Taylor, E.M., 1990, Volcanic history and tectonic development of the central High Cascade Range, Oregon: Journal of Geophysical Research, v. 95, no. B12, p. 19611-19622.

Wasco County Planning and Development Office, 1983 (last update 2010), Wasco County Comprehensive Plan, available at http://co.wasco.or.us/planning/wcCompPlan.html, accessed January 24, 2014.

Wells, R.E., Weaver, C.S., Blakely, R.J., 1998, Fore arc migration in Cascadia and its neotectonic significance: Geology, v. 26, p. 759-762.

Whalen, J.B., Currie, K.L., Chappell, B.W., 1987, A-type granites: Geochemical characteristics, discrimination and petrogenesis: Contributions to Mineralogy and Petrology, v. 95, p. 407-419.

Woods, M., 2004, Compositional and mineralogical relationships between mafic inclusions and host lavas as key to andesite petrogenesis at Mount Hood volcano, Oregon [M.S. Thesis]: Portland, Portland State University, 170 p.

U.S. Geological Survey, Alaska Department of Natural Resources, Arizona Geological Survey, California Geological Survey, Colorado Geological Survey, Idaho Geological Survey, Illinois State Geological Survey, Louisiana Geological Survey, Montana Bureau of Mines and Geology, Nevada Bureau of Mines and Geology, New Mexico Bureau of Mines and Mineral Resources, Texas Bureau of 
Economic Geology and Utah Geological Survey, 2006, Quaternary faults and fold database for the United States, available at http://geohazards.cr.usgs.gov/cfusion/qfault/index.cfm, accessed June 21, 2014.

U.S. Geological Survey, 2011, Wamic, Oregon [map]: U.S. Department of the Interior, U.S. Geological Survey, map scale 1:24,000. 


\section{Appendix A. Methods}

Thirty-one days were spent in the field over the course of two summers (20122013). In addition to mapping Graveyard Butte, exploratory and sample collection trips were made to Gordon Butte, Badger Creek, Hootnanny Point, Keeps Mill, McCubbins Gulch, and in the Bureau of Land Management's White River Wild and Scenic areas.

At Graveyard Butte, field work consisted of mapping the extents of geologic units and collecting rock and sediment samples for later analyses. Samples were labeled with a unique identifier and notations were made regarding locations and other site information in a field notebook. All geographic data were collected using a Garmin etrex Vista handheld GPS unit and plotted on 1:12,000 scale topographic map (Wamic quadrangle) using a mapping grid. The geologic map was prepared using ArcGIS software.

Rock samples from Graveyard and Gordon Buttes, McCubbins Gulch, Hootnanny Point and Mill Creek that were selected for major and trace element analysis were individually machine-chipped into a size fraction of approximately $0.5 \mathrm{~cm}$, using facilities at Portland State University. At the GeoAnalytical Laboratory of Washington State University (Pullman, Washington), approximately $120 \mathrm{~g}$ from each of the crushed samples were ground into powder using a tungsten carbide ring mill. A flux agent (dilithium tetraborate) was added to $3.5 \mathrm{~g}$ of the rock powder on a 1:1 ratio. The rock-flux was well-mixed, transferred to a carbon crucible, placed in a $1000^{\circ} \mathrm{C}$ oven and fused into a glass bead. For X-ray fluorescence spectrometer (XRF) analysis, the glass bead was reground into a powder and re-fused. For inductively-coupled plasma mass spectrometry (ICP-MS) analysis, $2 \mathrm{~g}$ of the flux was added to $2 \mathrm{~g}$ of rock power, mixed and fused into 
a glass bead. The glass bead was re-ground into a powder using a steel bowl. The XRF and ICP-MS analyses were conducted by personnel at the WSU GeoAnalytical Laboratory. Geochemical analyses were prepared using GCDKit (Janoušek et al., 2006), written for R statistical and computing software.

Billets were cut and sent to a local petrographic company for completed thin sections. Petrographic analysis was conducted at Portland State University. The thin sections were carbon-coated using the sputter coater and scanning electron microscope micrographs were collected using an Aspex Express located in the petrology laboratory at the U.S. Geological Survey-Cascades Volcano Observatory (Vancouver, Washington). Images were processed using Perception software.

Age dating experiments were conducted at facilities located in Oregon State University's College of Earth, Ocean and Atmospheric Sciences (Corvallis, Oregon). Samples selected for age analyses were individually machine-chipped into fragments of less than $1 \mathrm{~mm}$. The samples were sieved into size fractions of 106-250 $\mu \mathrm{m}$, and 250$500 \mu \mathrm{m}$ in an effort to obtain the largest crystals; crystalline groundmass was also sampled when too few crystals were found. Using a Frantz Isodynamic Separator, the non-magnetic portion of the sieved sample was collected; a binocular microscope was used to examine the grains to confirm the presence of feldspar. The sample was leached with acid (HF) to remove quartz and other rock fragments and placed into packets for irradiation; the groundmass sample was not leached. The samples, along with Fish Creek Tuff biotite (28.030 \pm 0.003 Ma used for sample S12-6; 28.030 \pm 0.571 Ma used for 
samples CC14, GB4-3 and X3) as a neutron-flux monitor, were packed into vials and irradiated at the OSU research reactor. Analyses were conducted using the MAP215-50 single-collector mass spectrometer, and later, by the automated ARGUS VI multicollector. The results were analyzed using the ArArCalc software developed by OSU's Dr. Anthony Koppers (Koppers, 1998).

Strontium isotope analysis was conducted by Portland State University graduate student Emily Jenkins Hess using facilities at New Mexico State University. 


\title{
Appendix B. Illustrative Stratigraphic Sections
}

\section{Representative stratigraphic section of sedimentary units in the Wasco County}

\author{
quarry by depth (m) from the surface (see Figure 11).
}

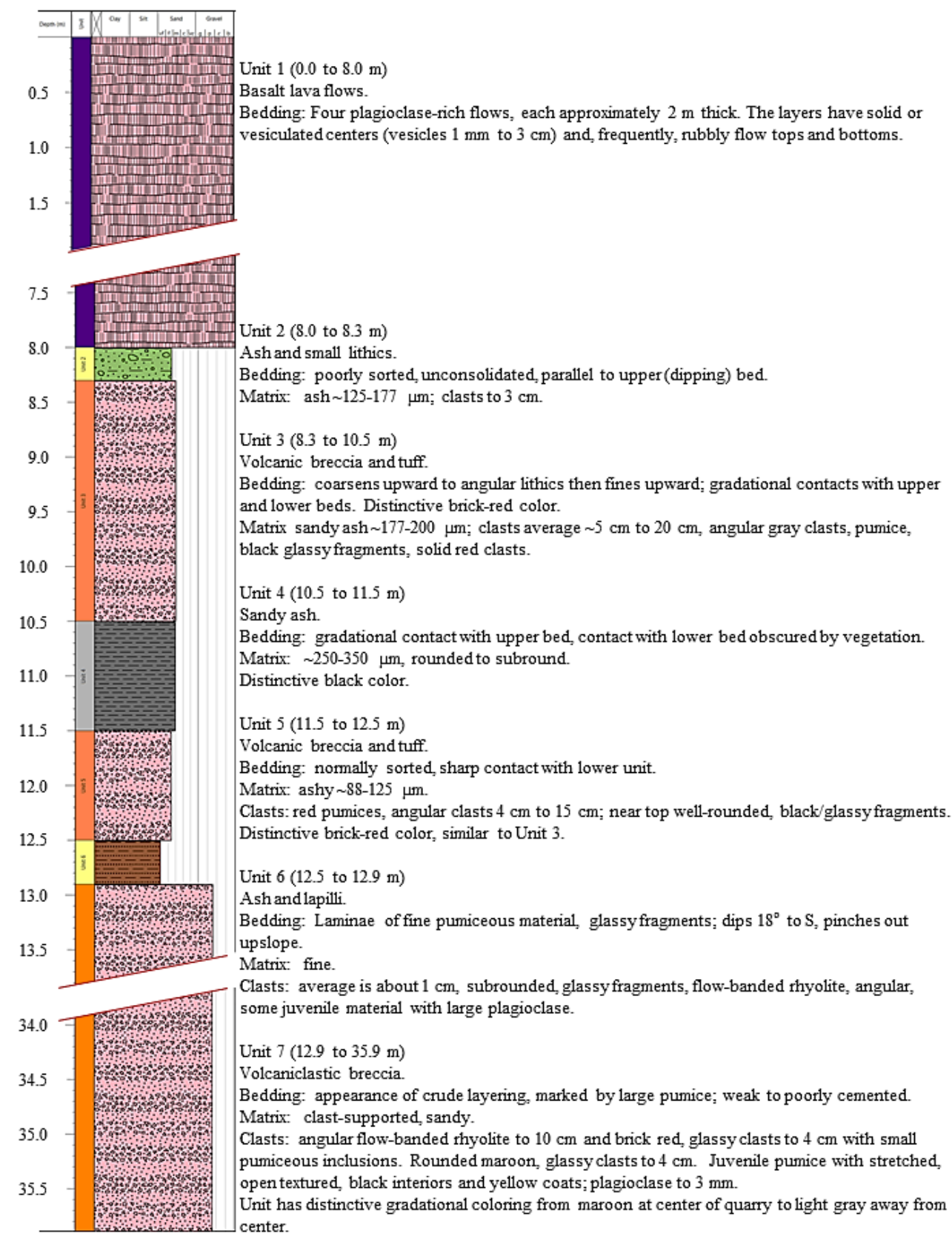


Sediments at the White River canyon downstream of the White River Crossing bridge, by depth (m) from the surface (see Figure 12).

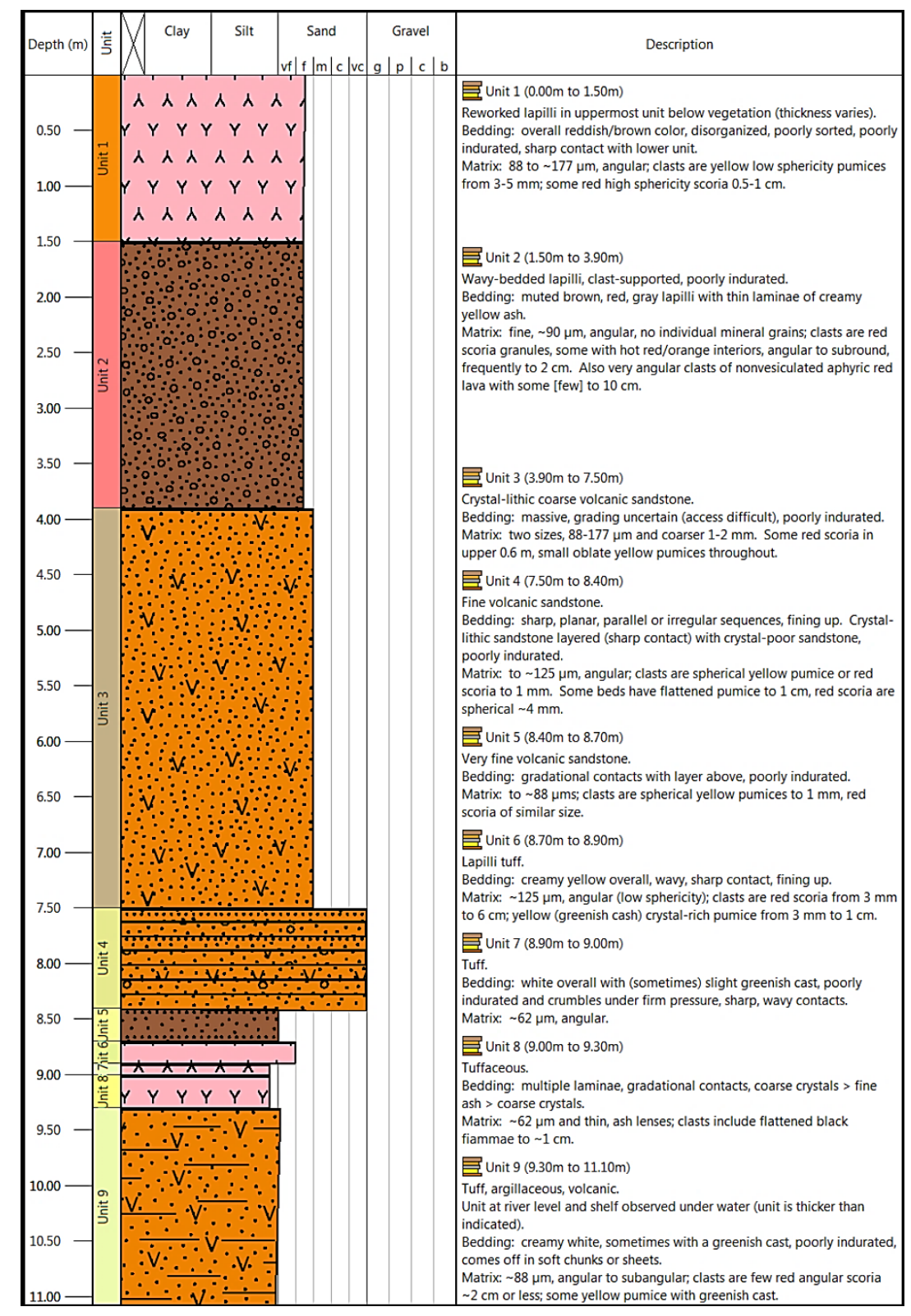




\section{Appendix C. Energy Dispersive Spectra}

Rhyolite (sample S6-13)

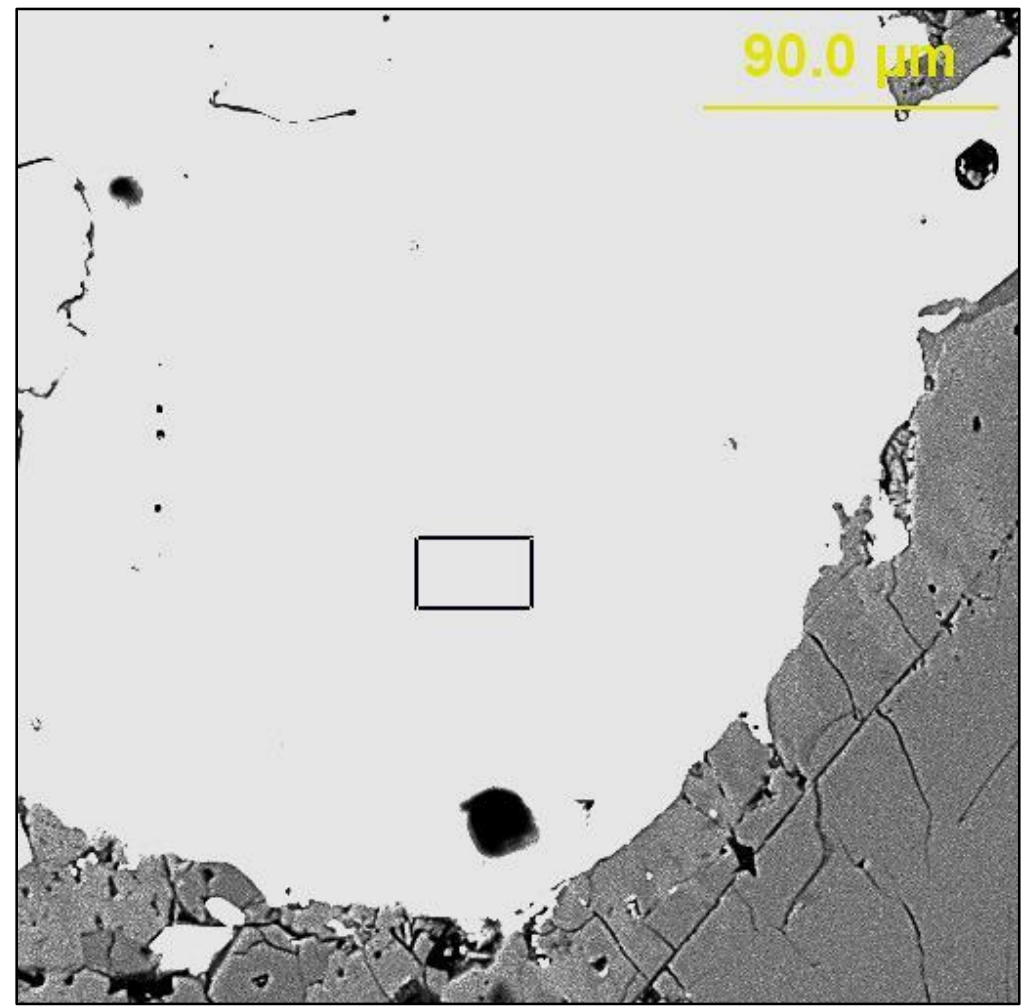

Sample S6-13

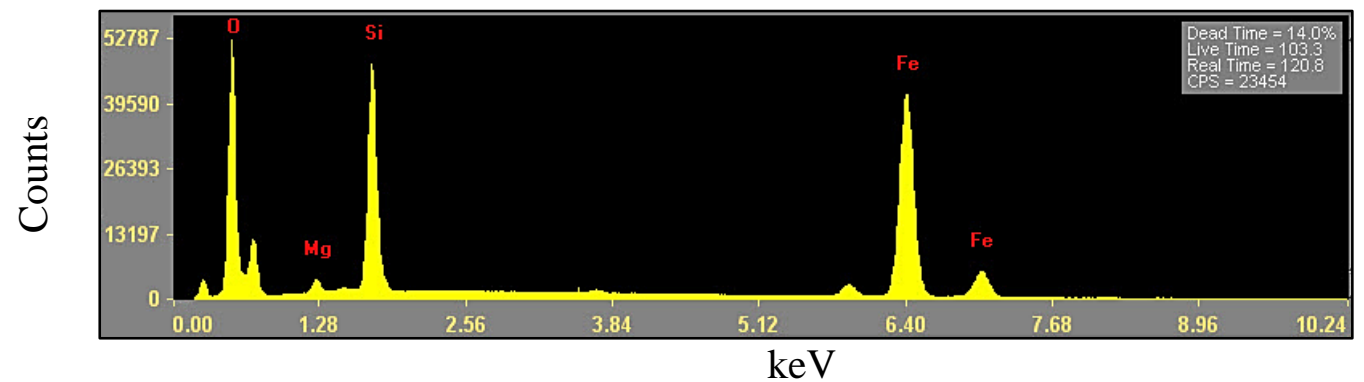




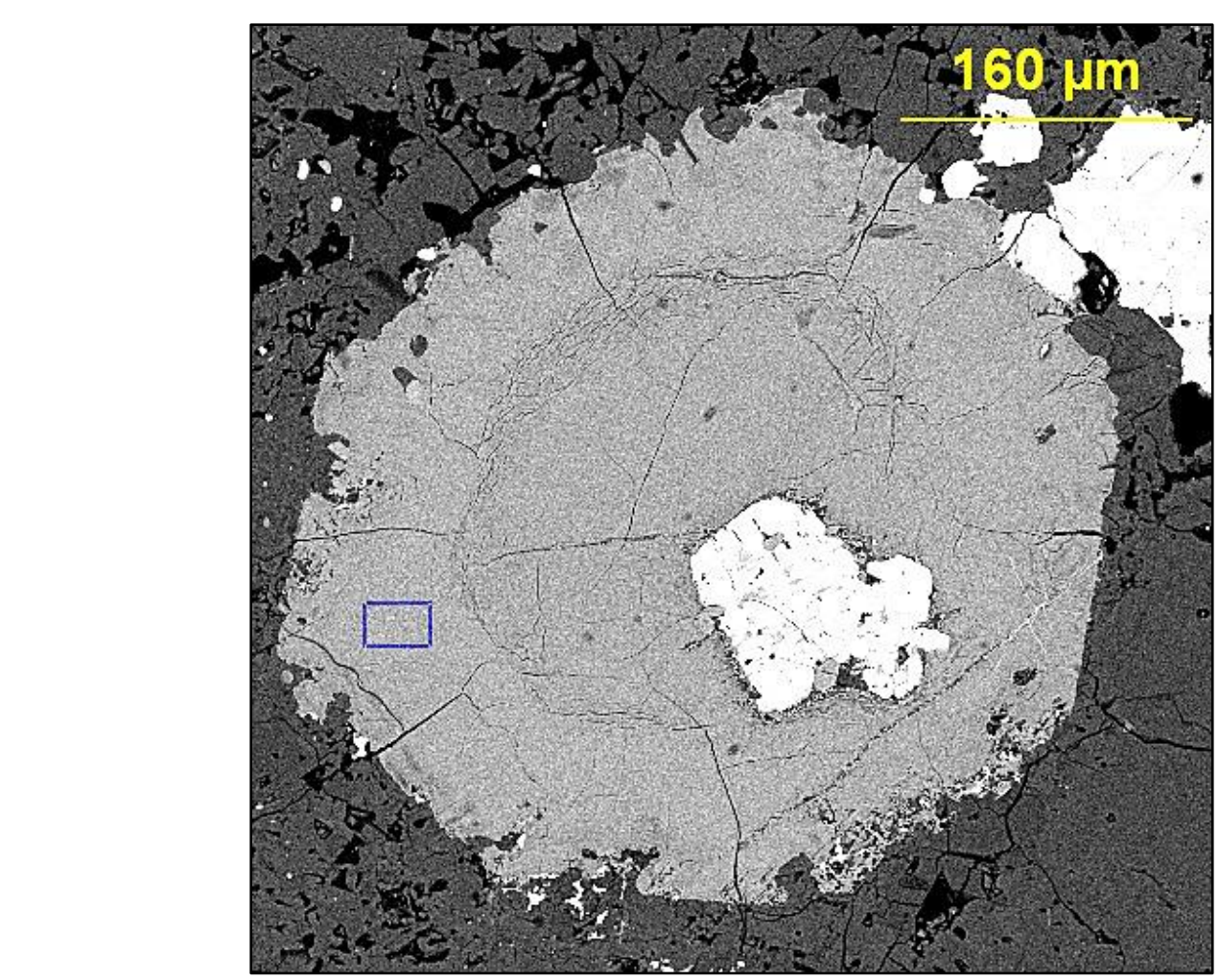

Sample S6-13

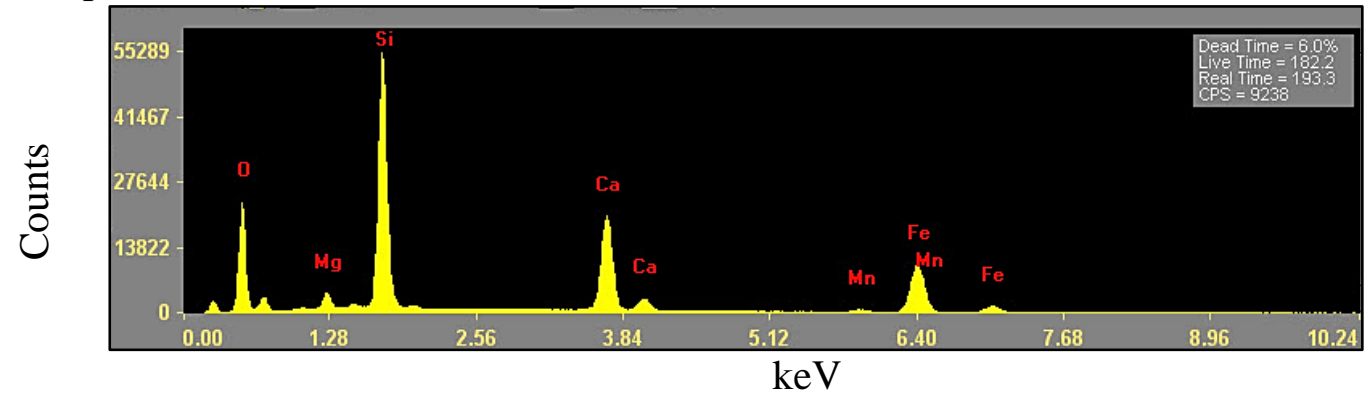




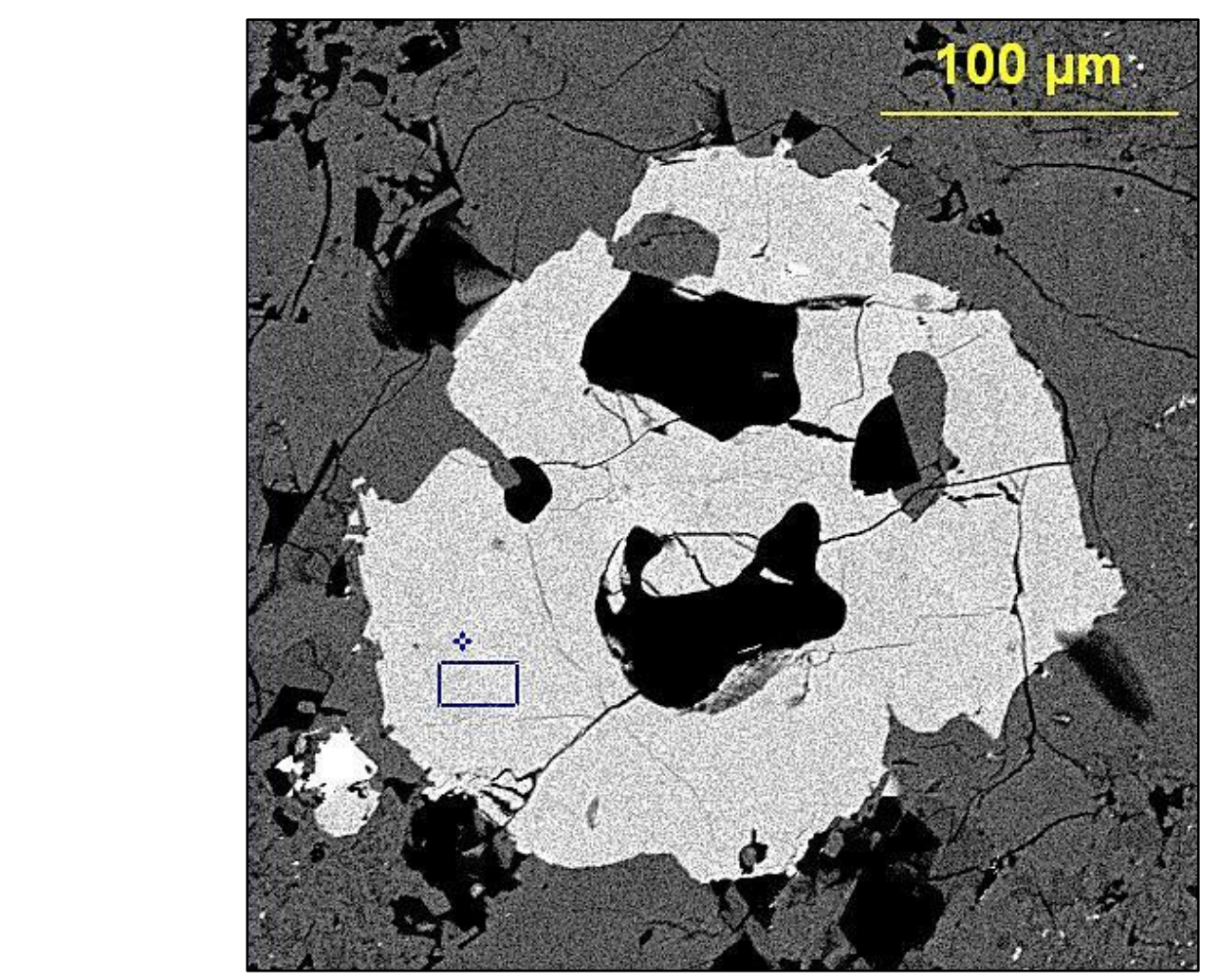

Sample S6-13

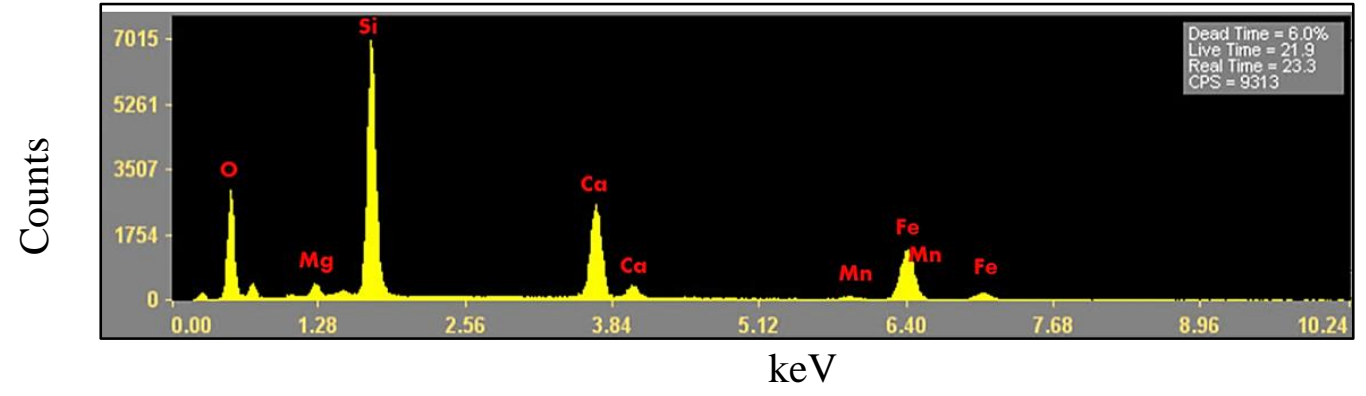




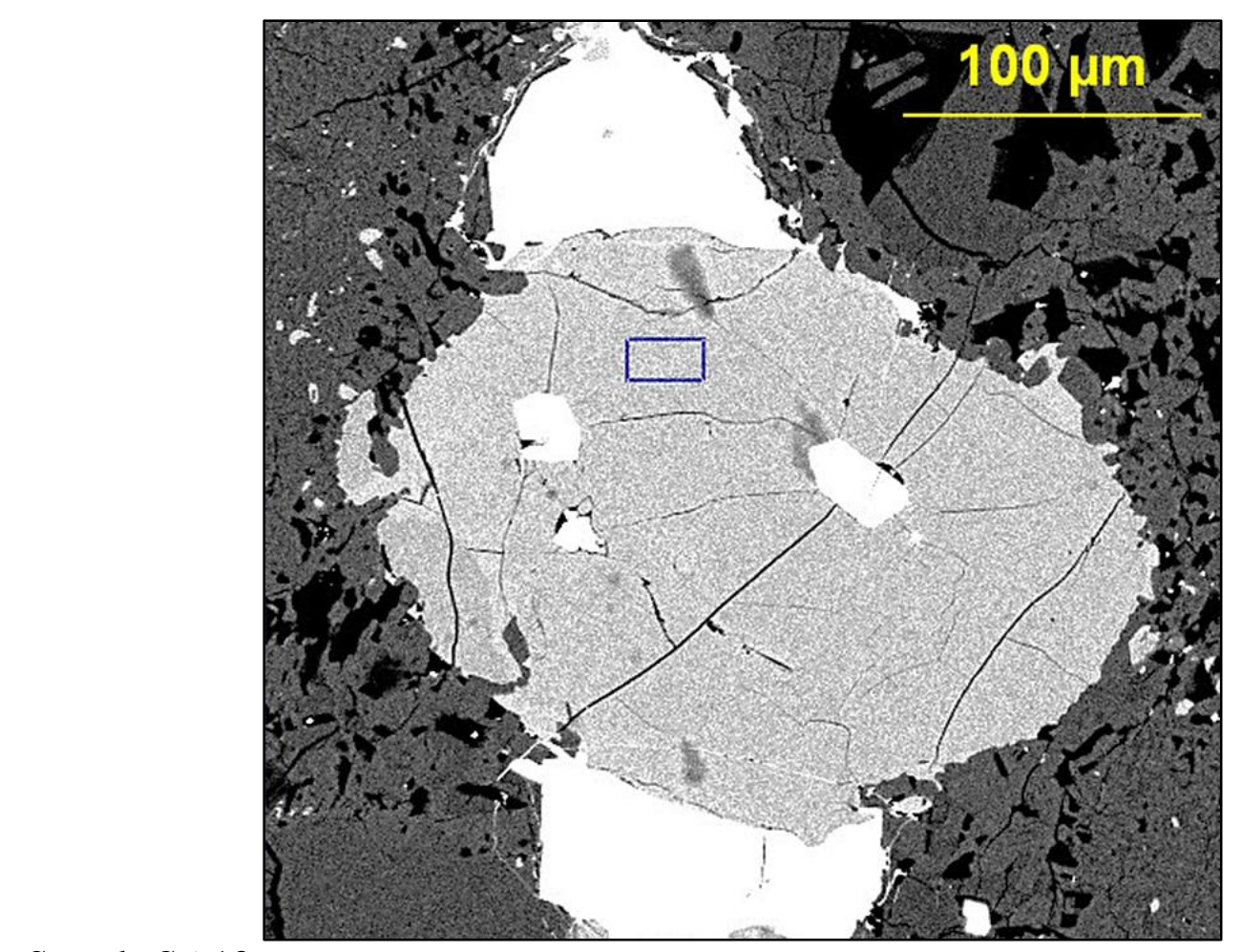

Sample S6-13

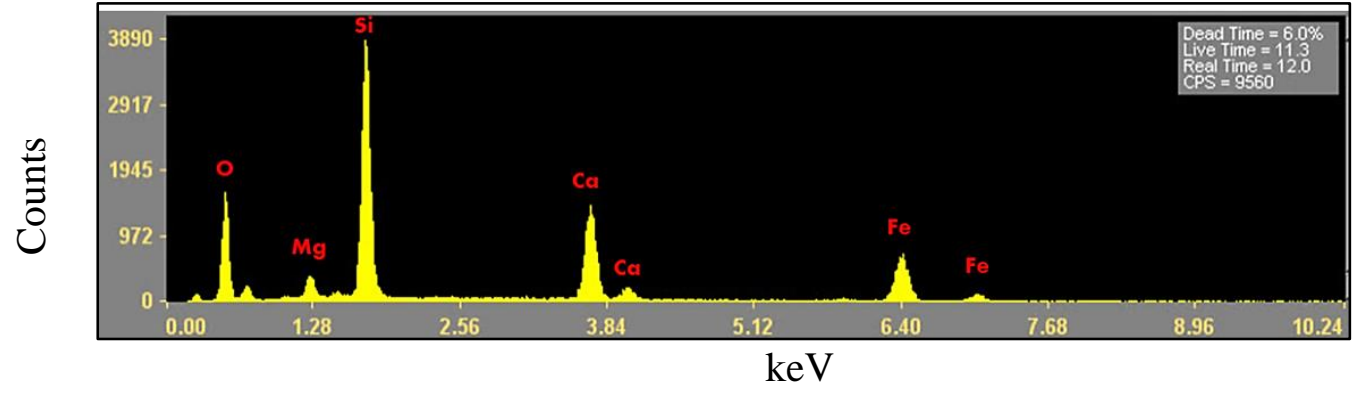




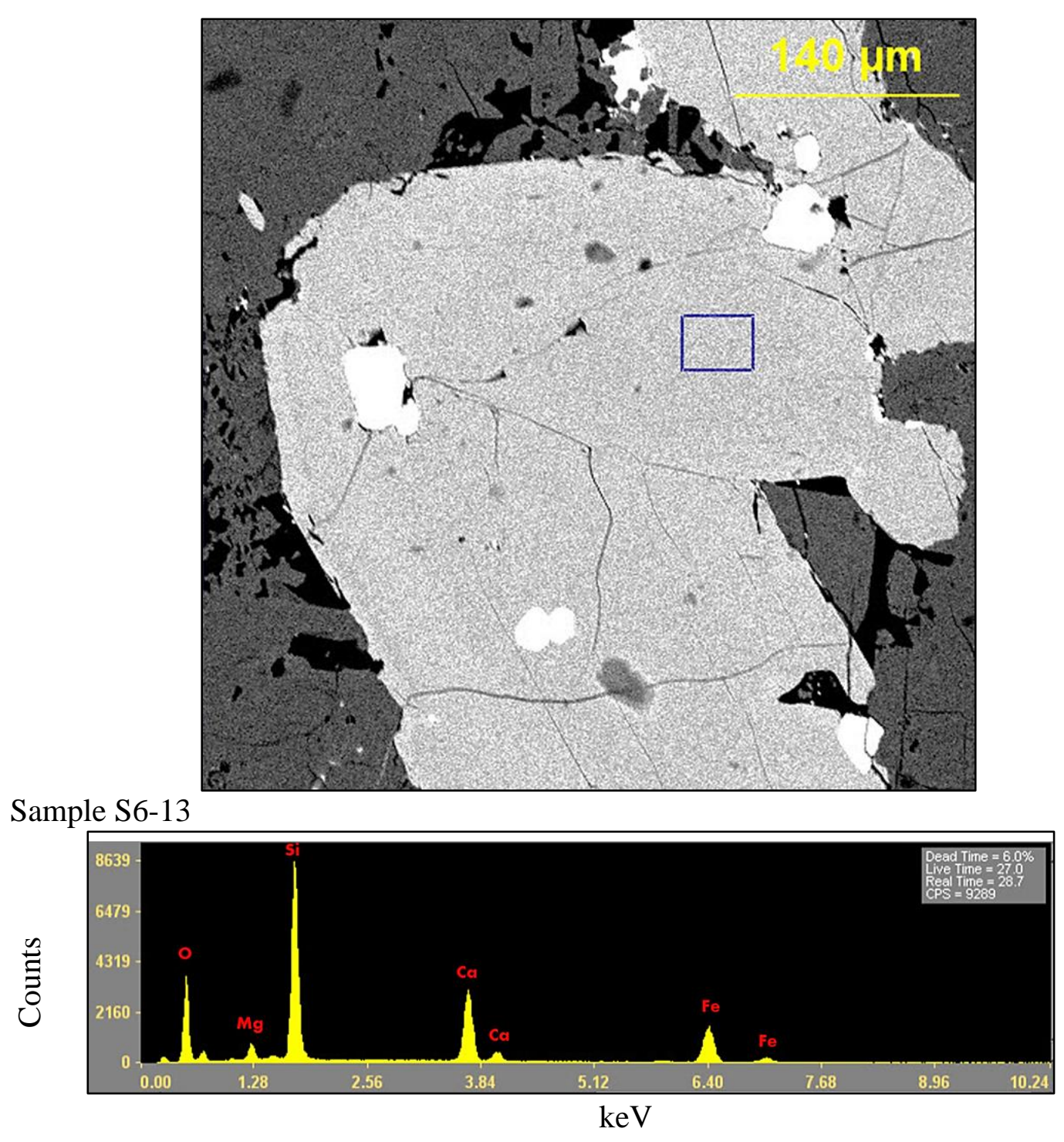




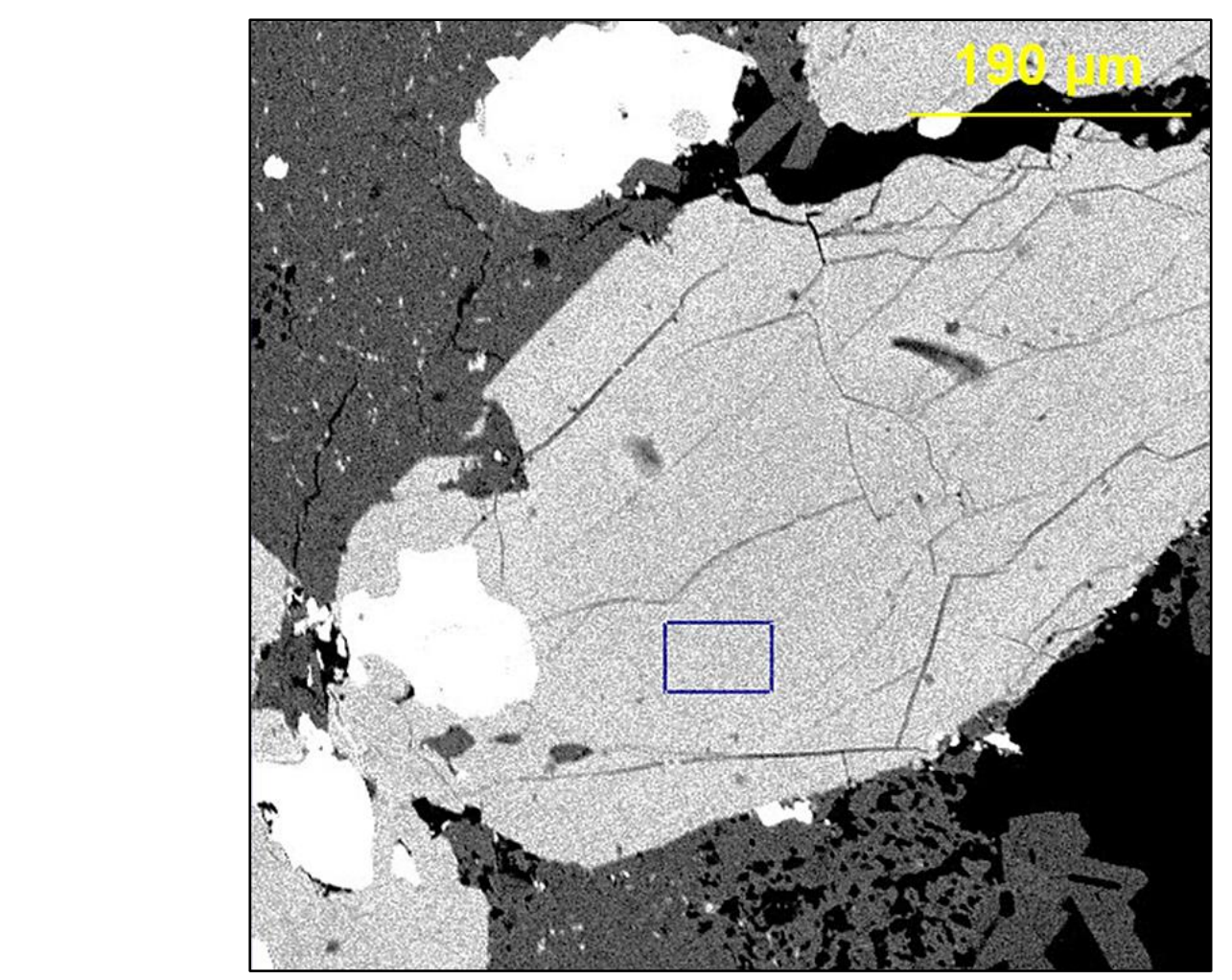

Sample S6-13

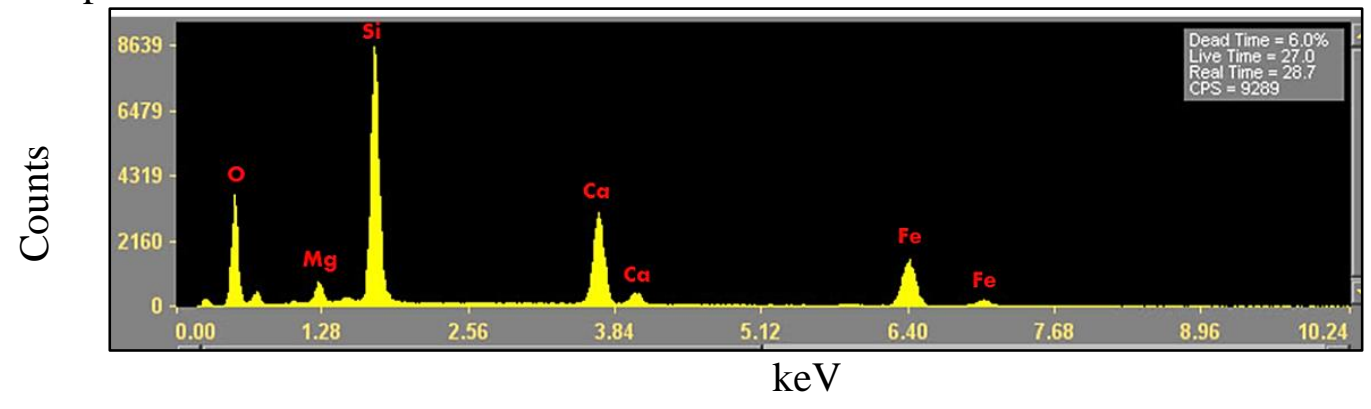




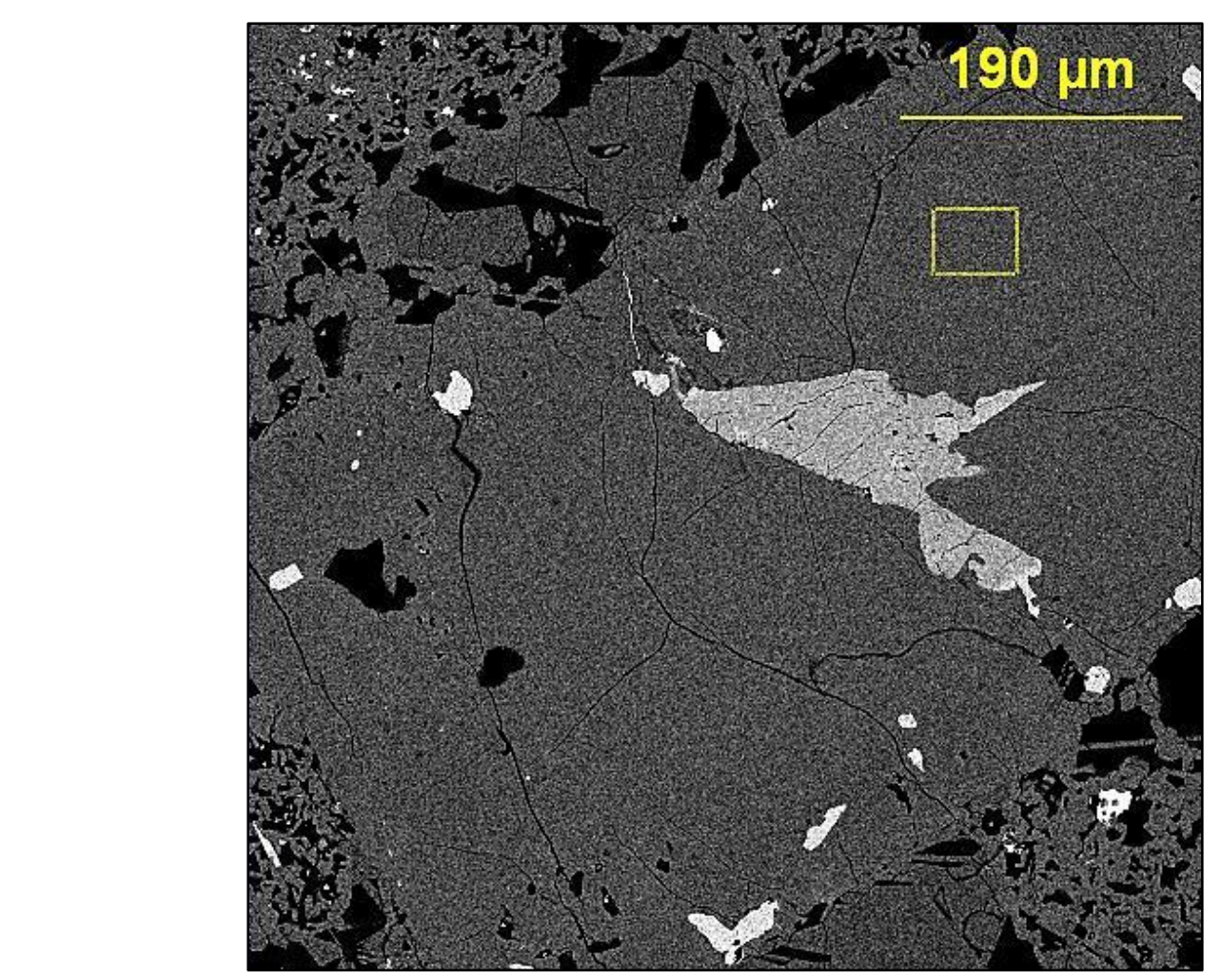

Sample S6-13

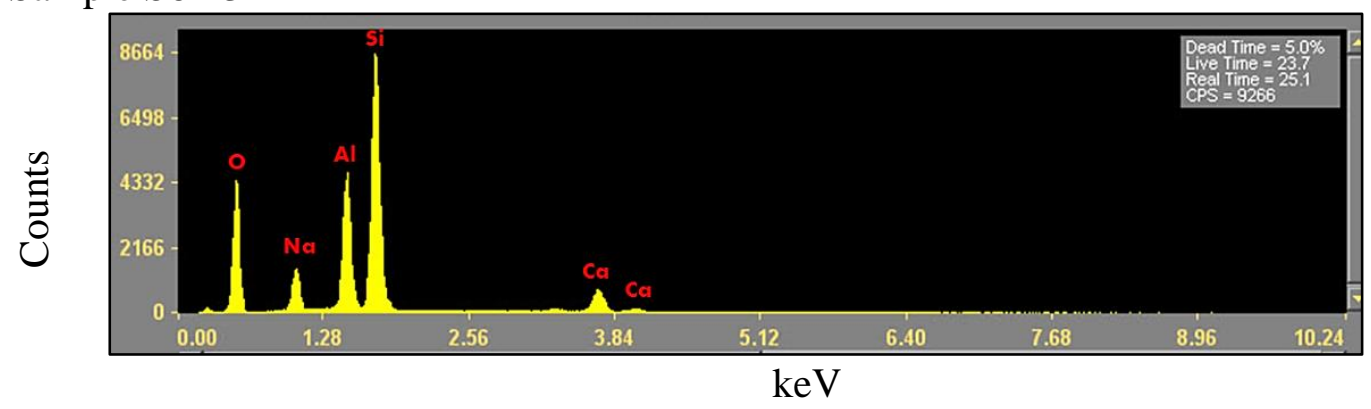




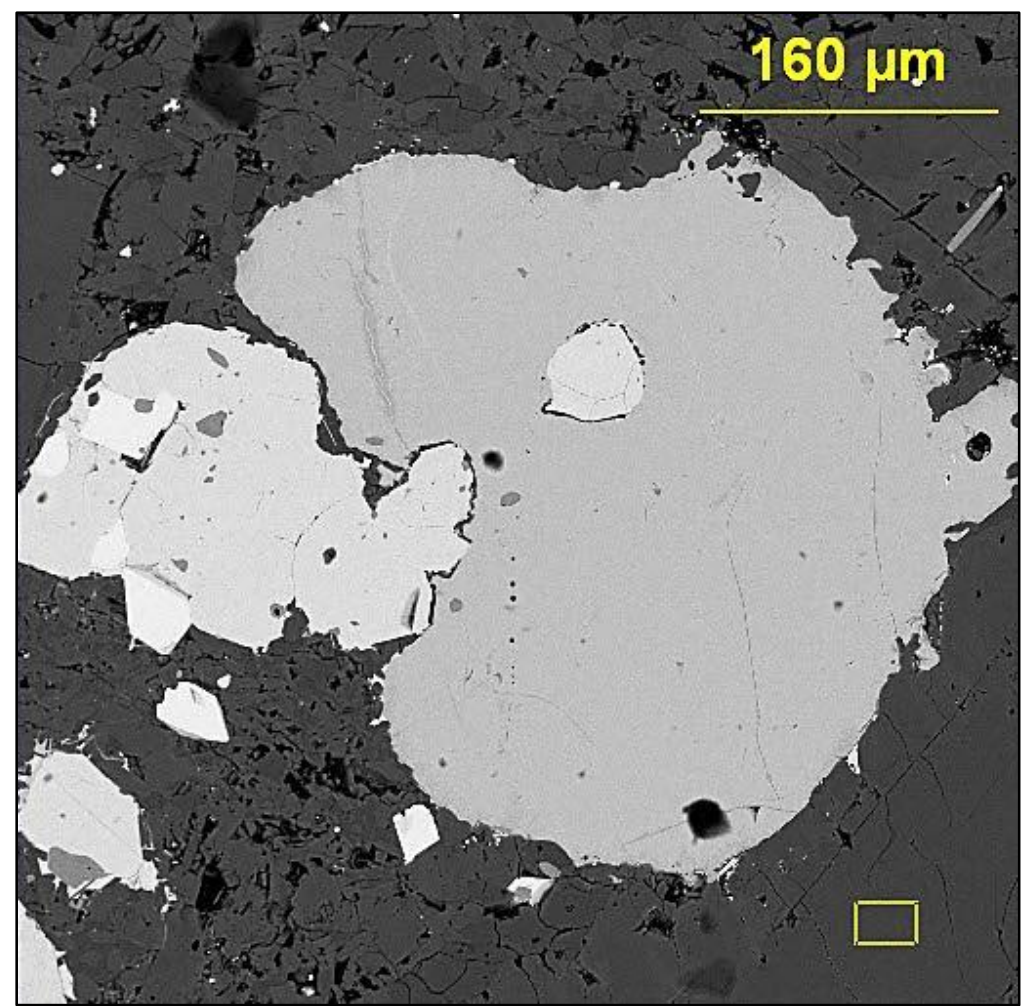

Sample S6-13

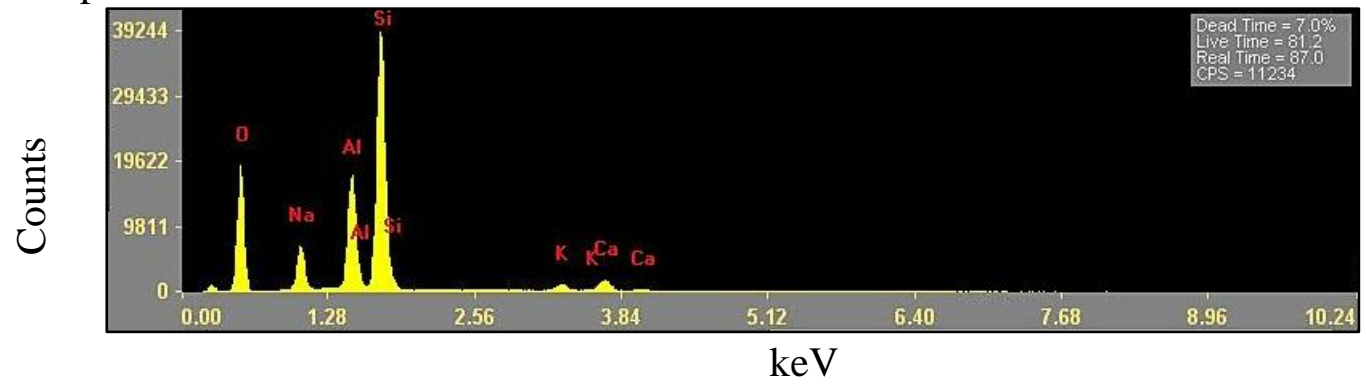




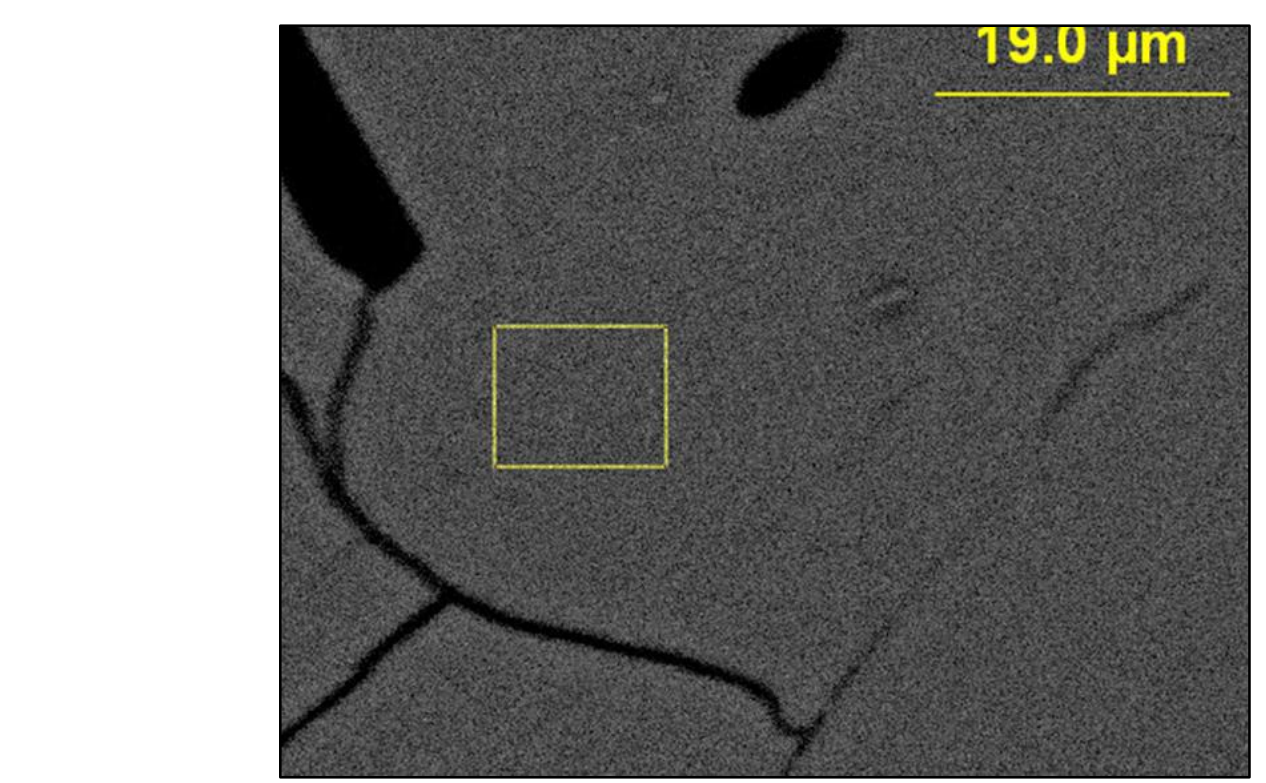

Sample S6-13

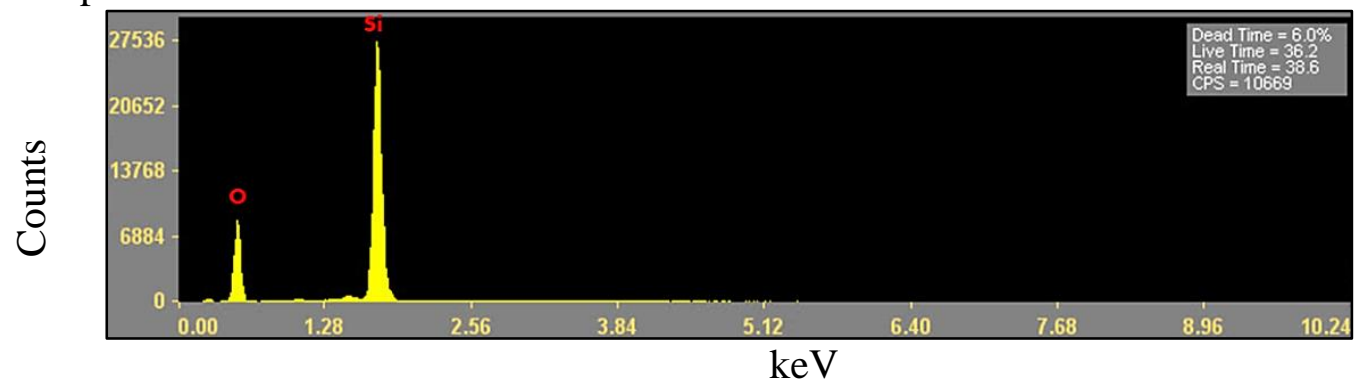




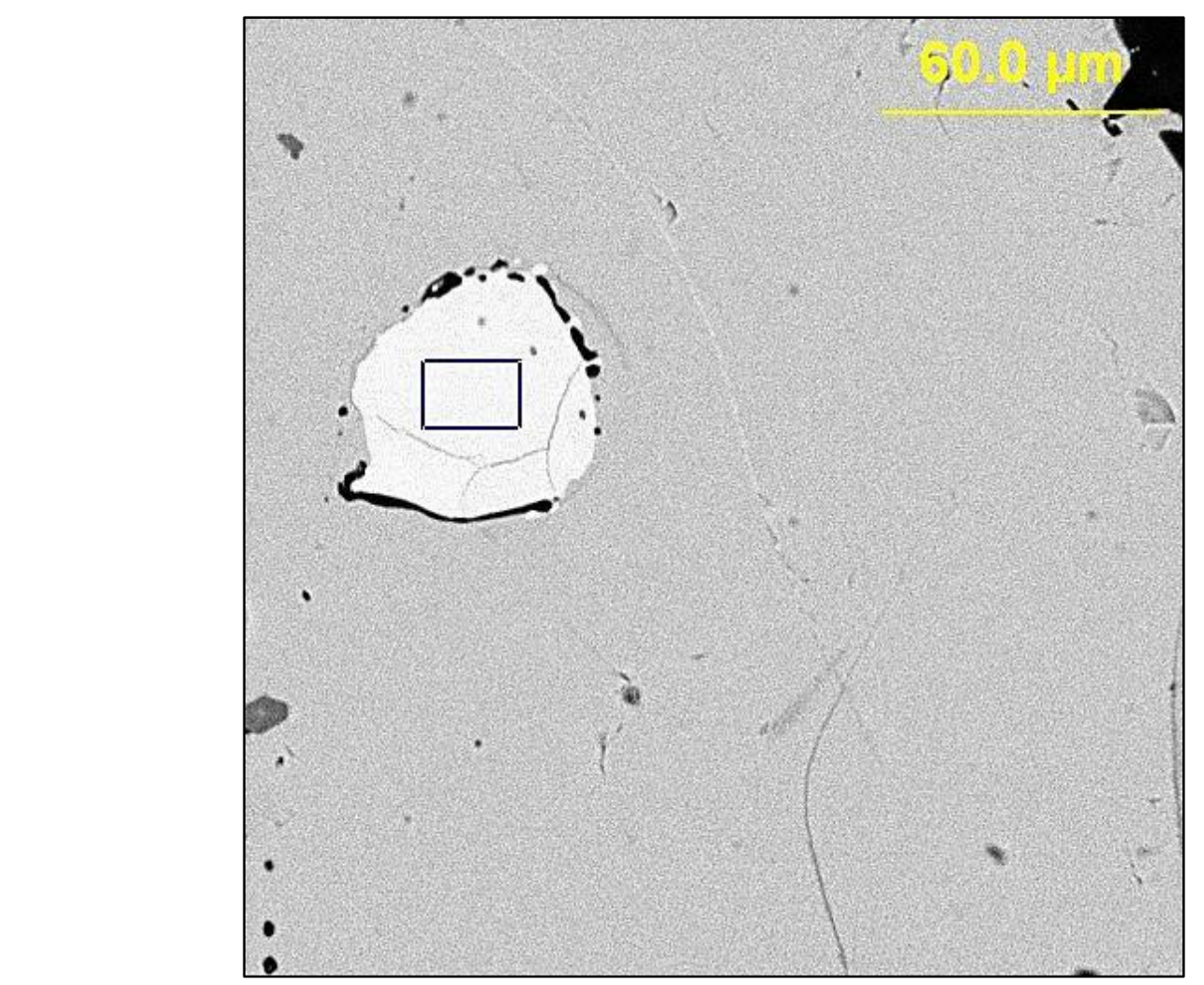

Sample S6-13

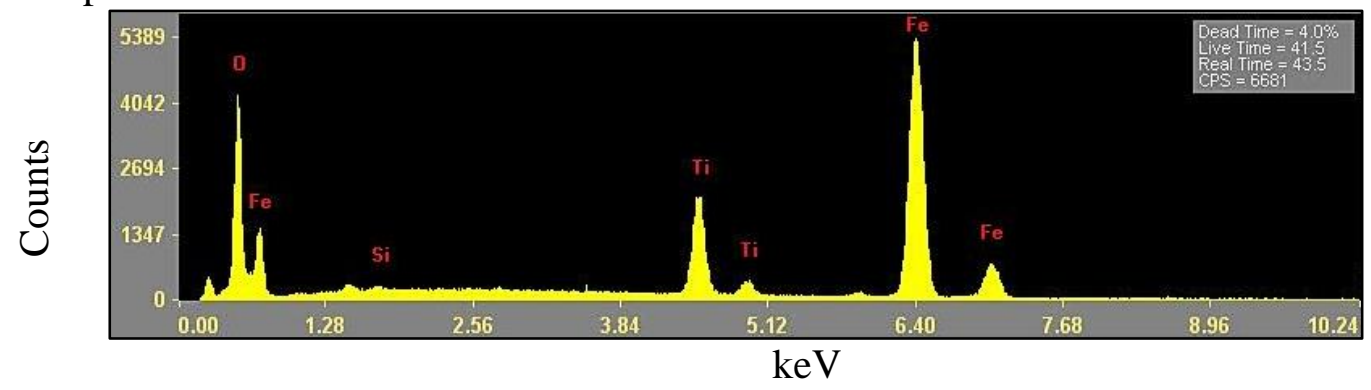




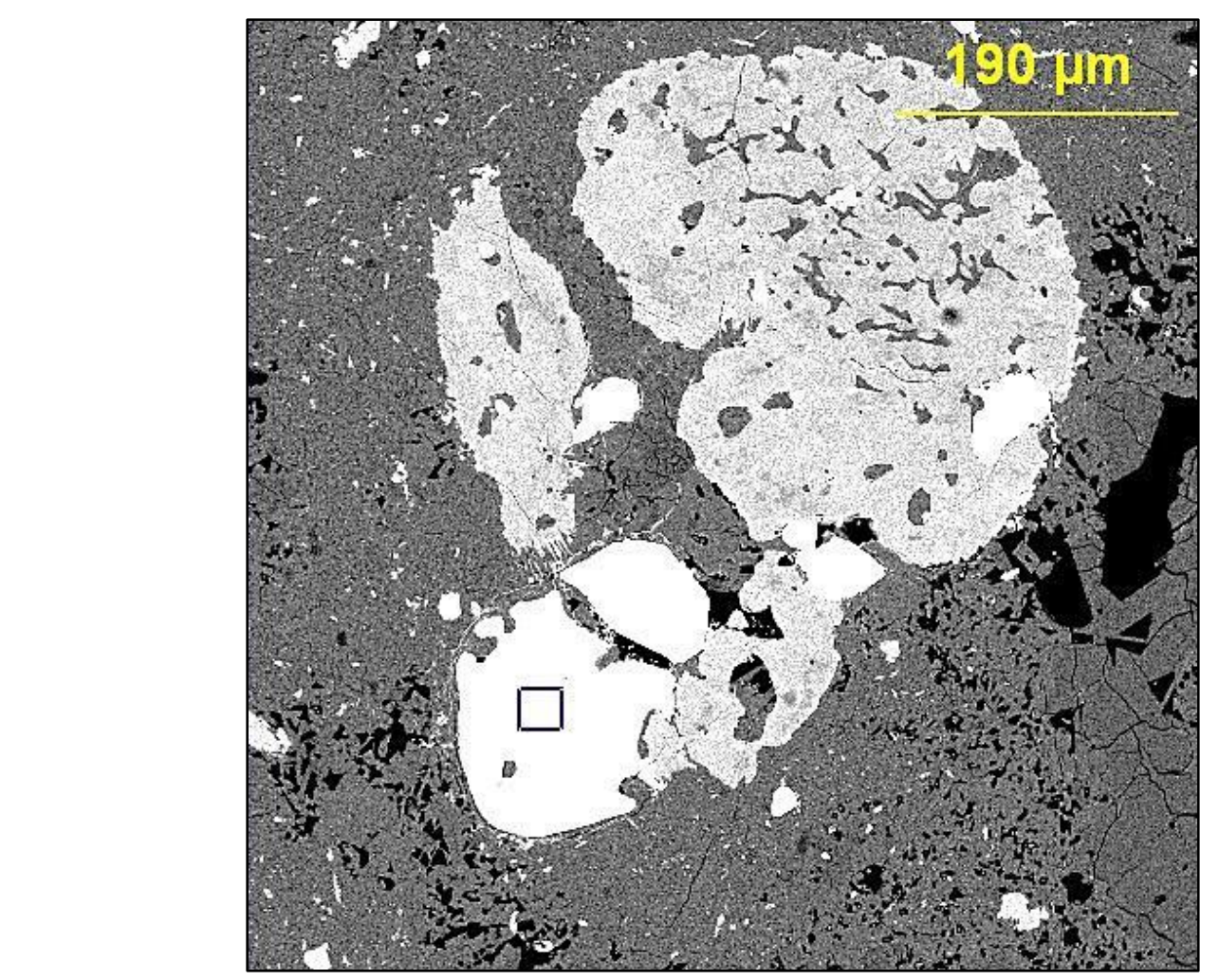

Sample S6-13

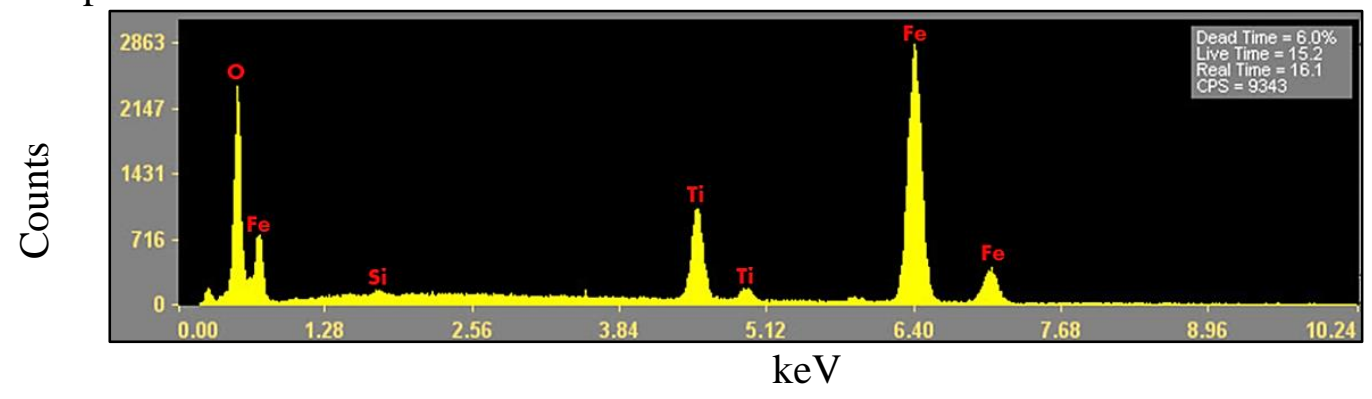




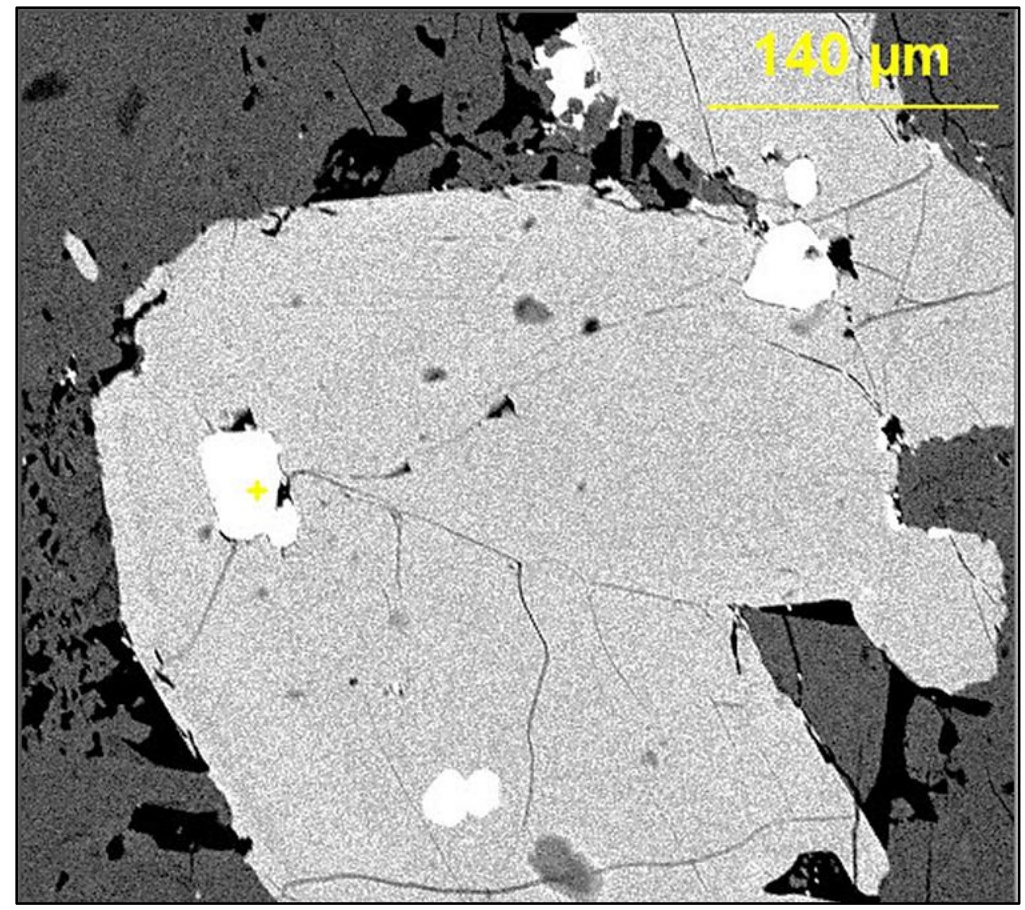

Sample S6-13

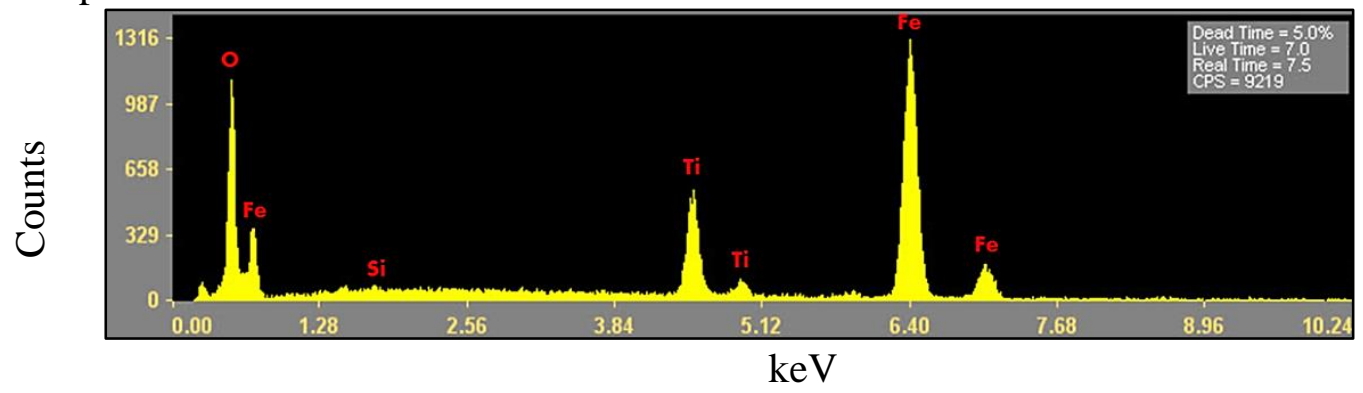




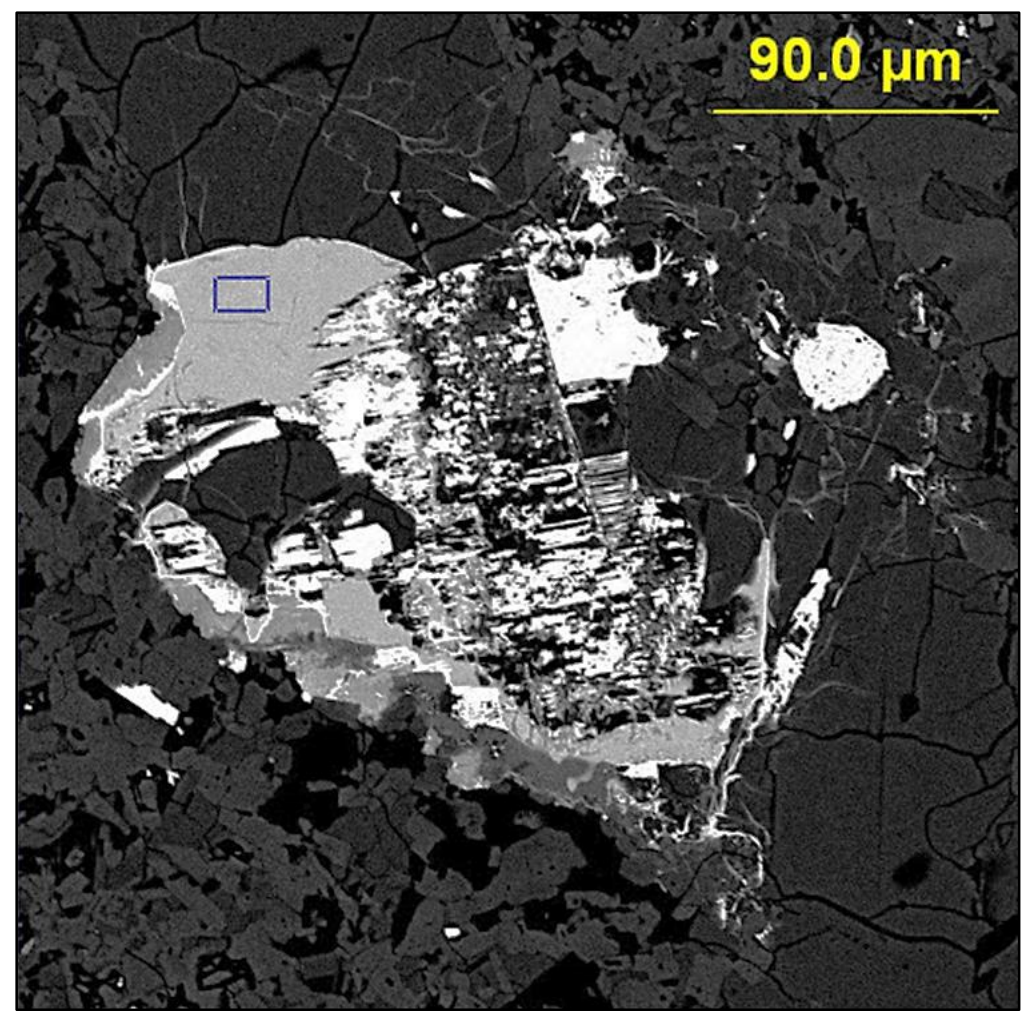

Sample S6-13

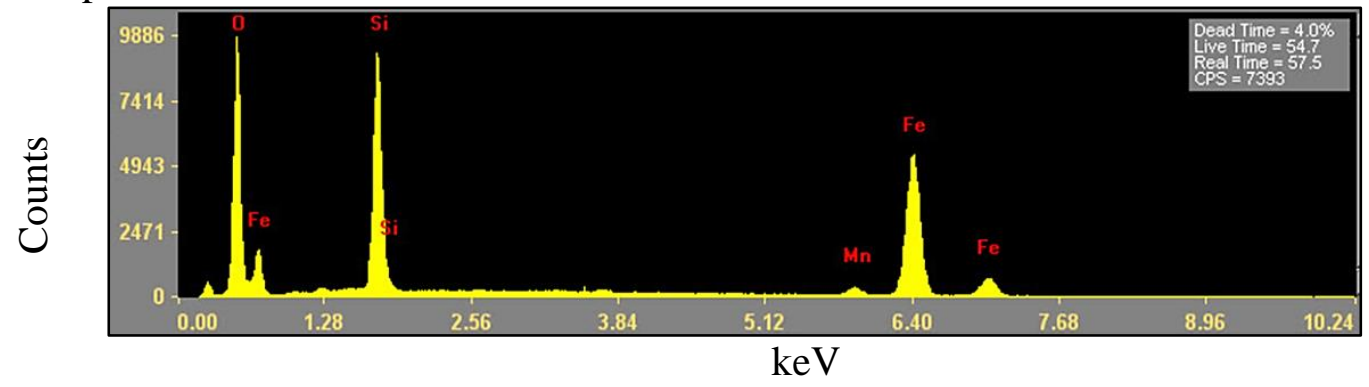




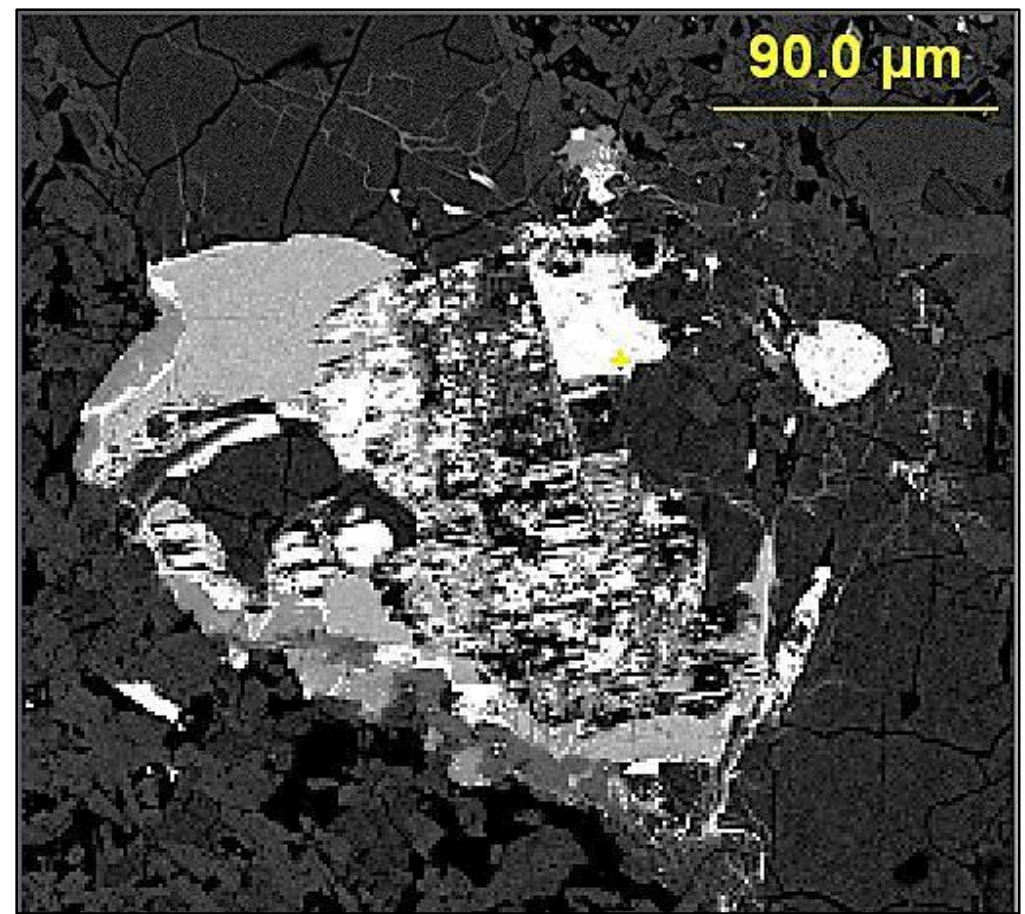

Sample S6-13

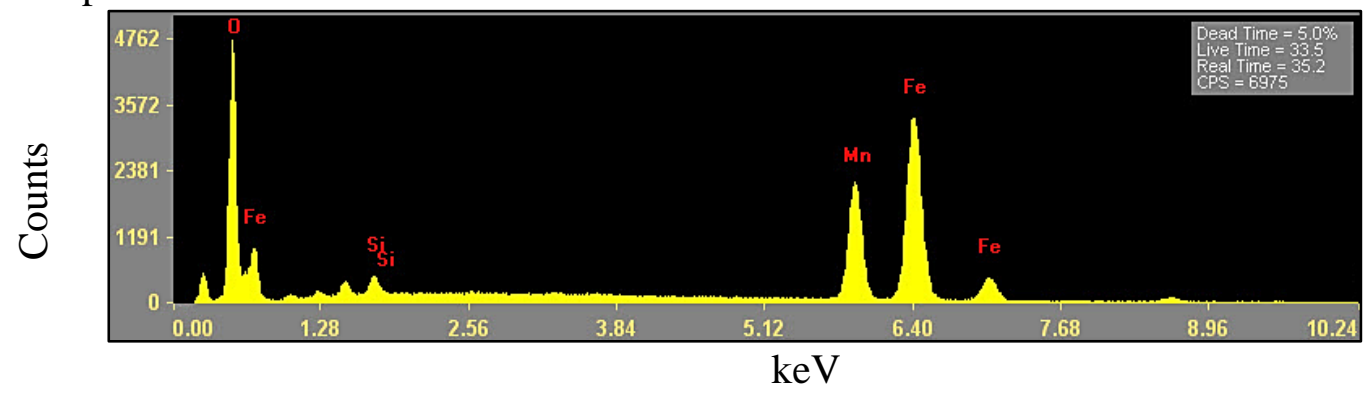


Basalt (sample WR11)

\section{USGS CVO ASPEX EXpress}

$12 / 26 / 2013$

C:IDocuments and Settings\AIl Users\Documents\ASPEXLizITygh Valley SamplesIWR11_25.TIF

02:53:13 PN
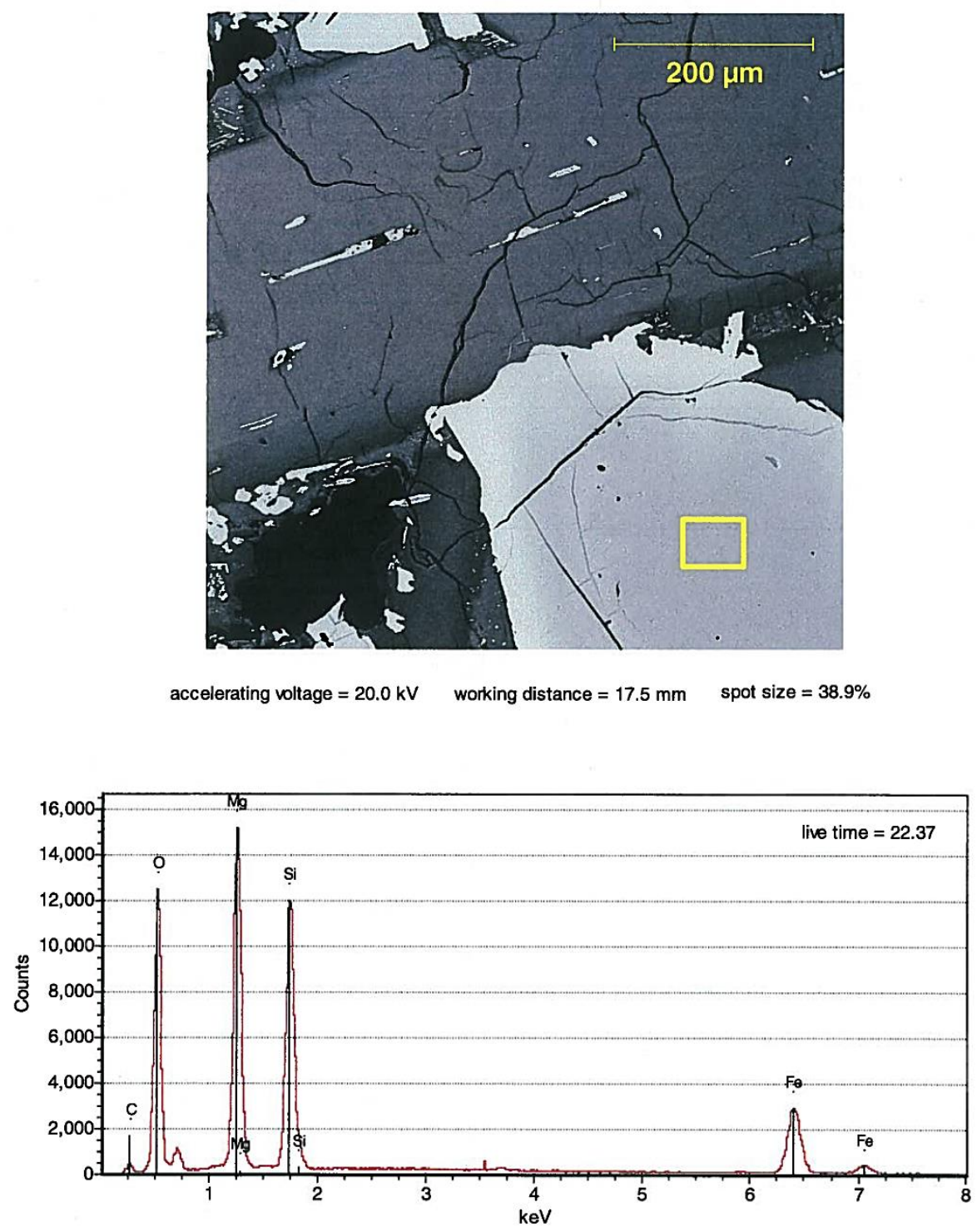
Basalt (sample WR11)

\section{USGS CVO ASPEX EXpresS}

$12 / 26 / 2013$

C:IDocuments and Settings\All Users IDocuments\ASPEXLizITygh Valley SamplesIWR11_26.TIF

02:54:15 PN

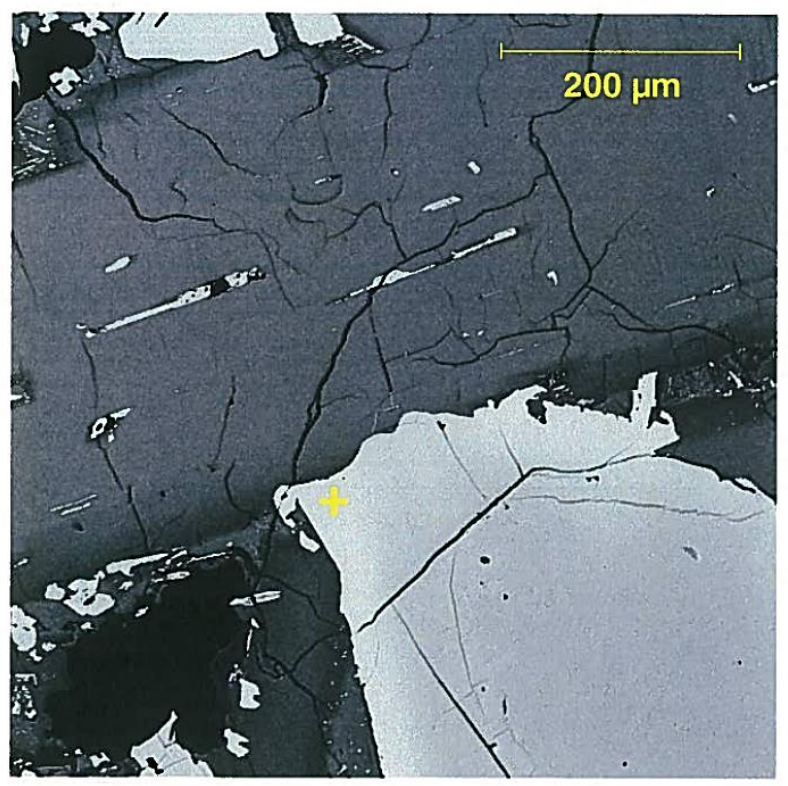

accelerating voltage $=20.0 \mathrm{kV}$

working distance $=17.5 \mathrm{~mm}$

spot size $=38.9 \%$

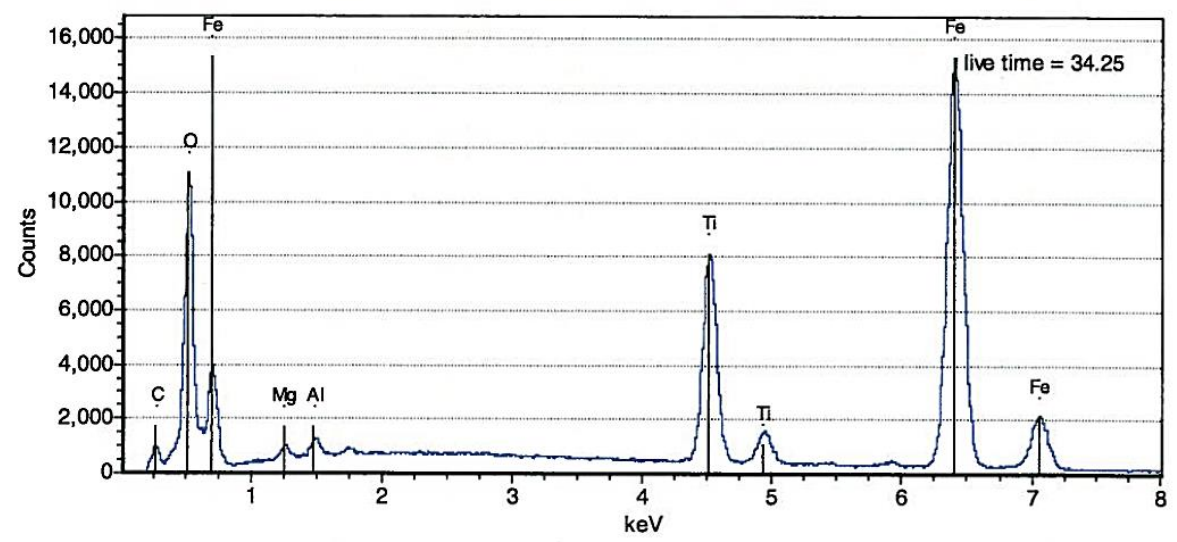


Basalt (sample WR11)

USGS CVO ASPEX EXpress

$12 / 26 / 2013$

C:IDocuments and SettingsLAII UsersIDocumentsLASPEXLizITygh Valley SamplesIWR11_16.TTF

02:01:42 PN
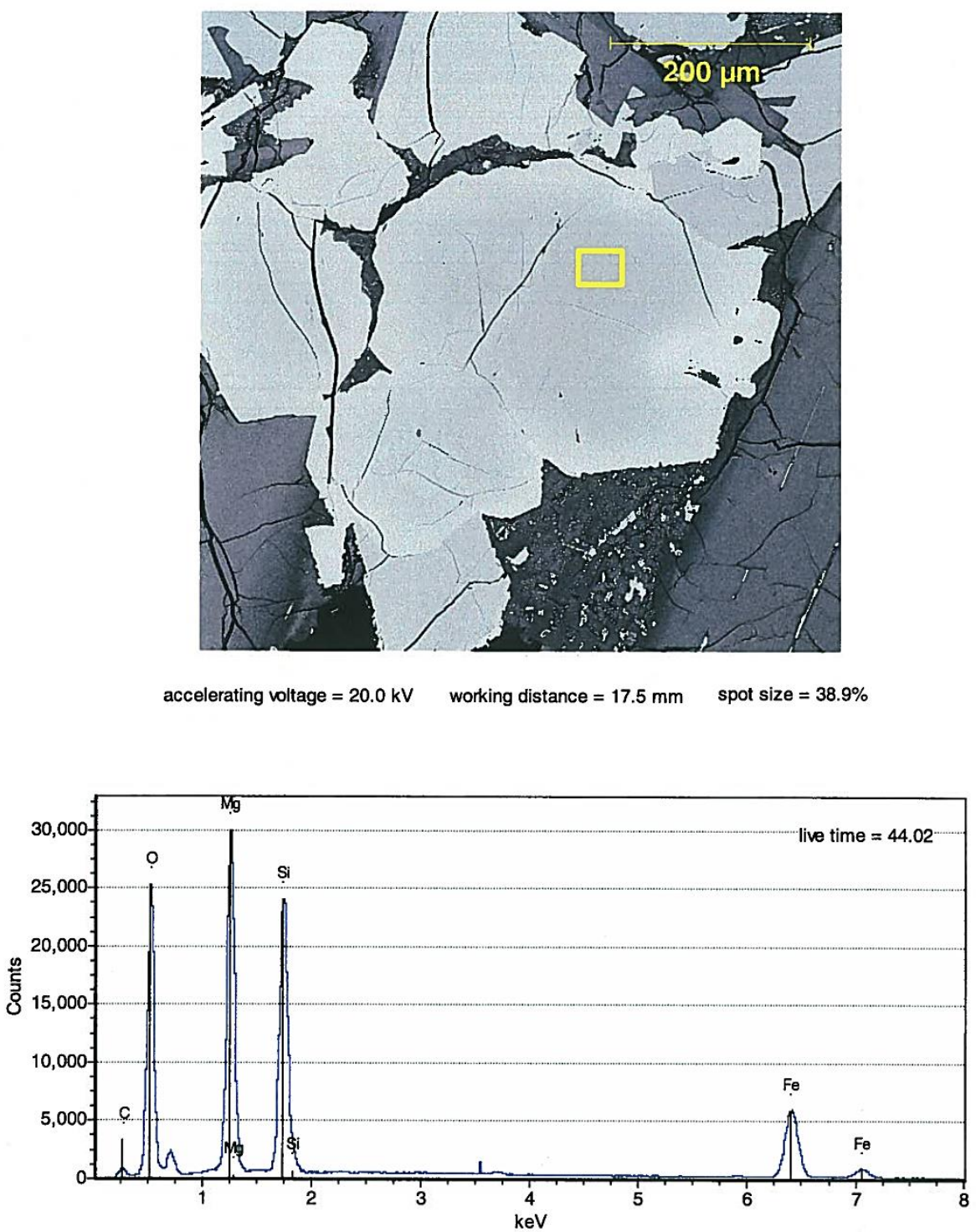
Basalt (sample WR11)

\section{USGS CVO ASPEX EXpress}

$12 / 26 / 2013$

C:IDocuments and SettingsLAll UsersIDocumentsLASPEXLLizITygh Valley SamplesIWR11_15.TIF

01:59:43 PA
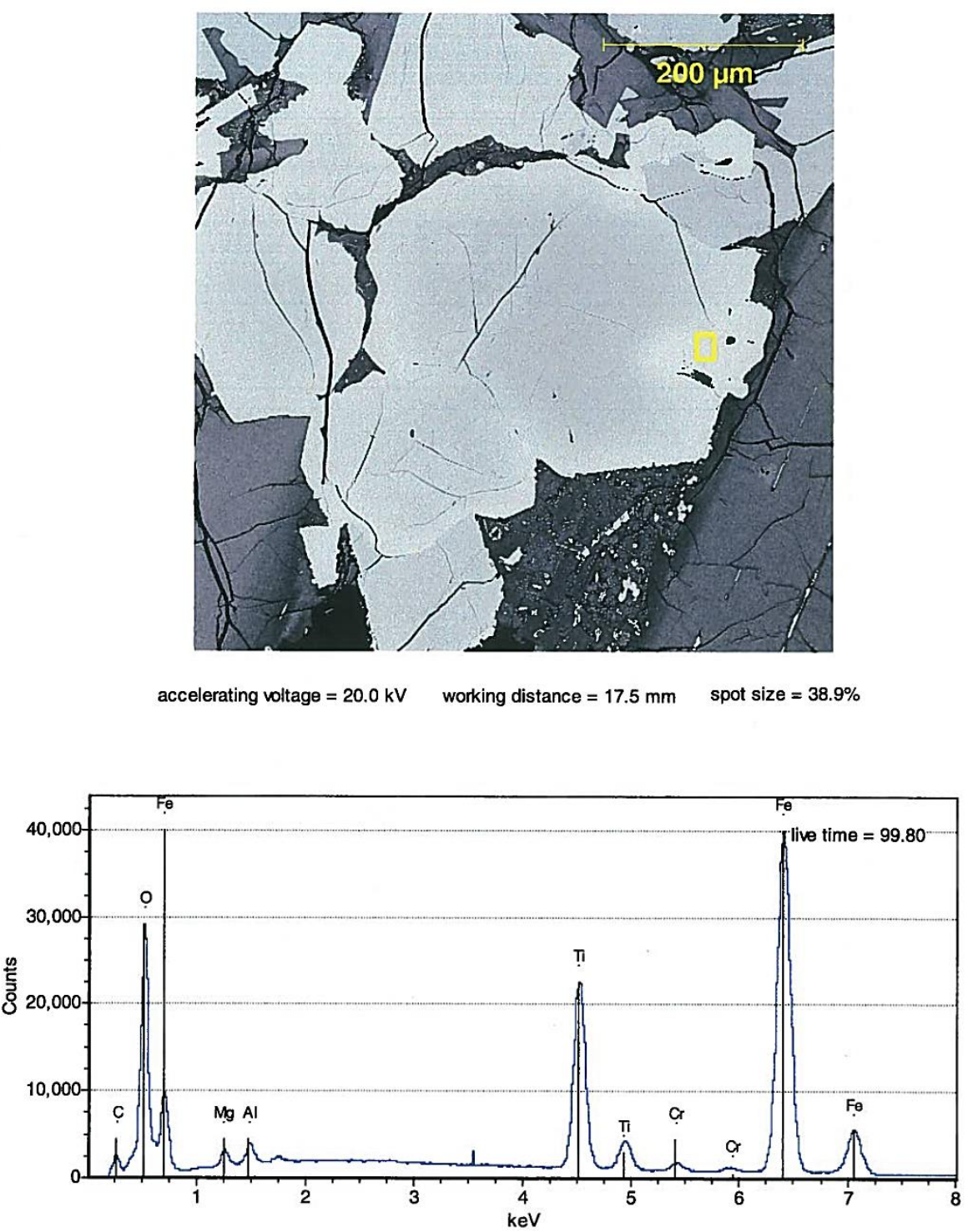
Basalt (sample WR11)

\section{USGS CVO ASPEX EXpress}

$12 / 26 / 2013$

C:IDocuments and Settings\All Users IDocuments\ASPEXILizITygh Valley SamplesIWR11_17.TFF

02:03:28 PN
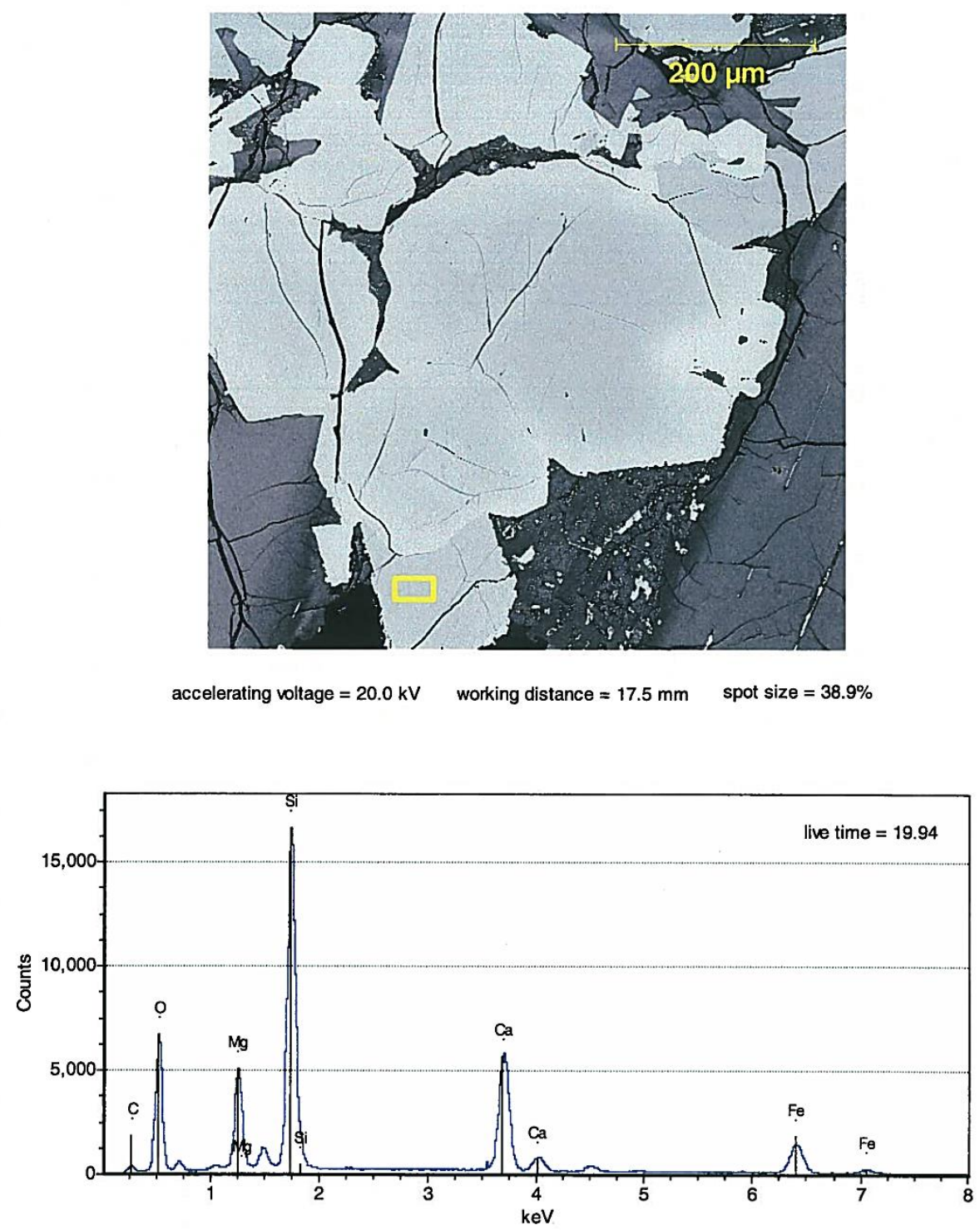
Basalt (sample WR11)

USGS CVO ASPEX EXpress

$12 / 26 / 2013$

C:IDocuments and Settings\AII UsersIDocumentsLASPEXLLizITygh Valley SamplesIWR11_24.TIF

02:51:47 PN

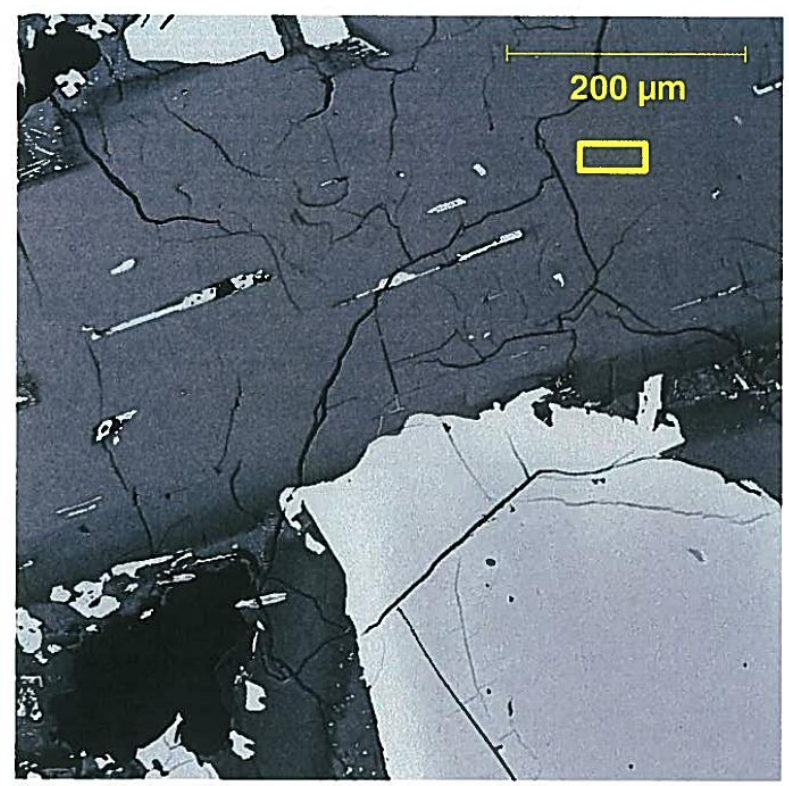

accelerating voltage $=20.0 \mathrm{kV}$

working distance $=17.5 \mathrm{~mm}$

spot size $=38.9 \%$

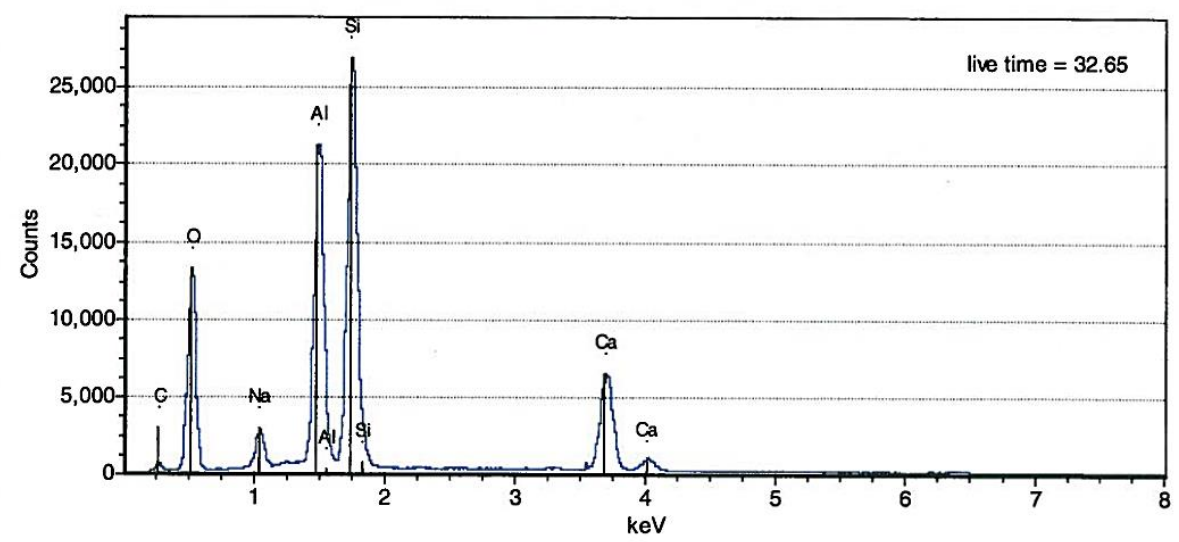


Basalt (sample WR11)

\section{USGS CVO ASPEX EXpress}

$12 / 26 / 2013$

C:IDocuments and Settings\AII UsersIDocumentsLASPEXLizITygh Valley SamplesIWR11_12.TF

01:41:28 PN

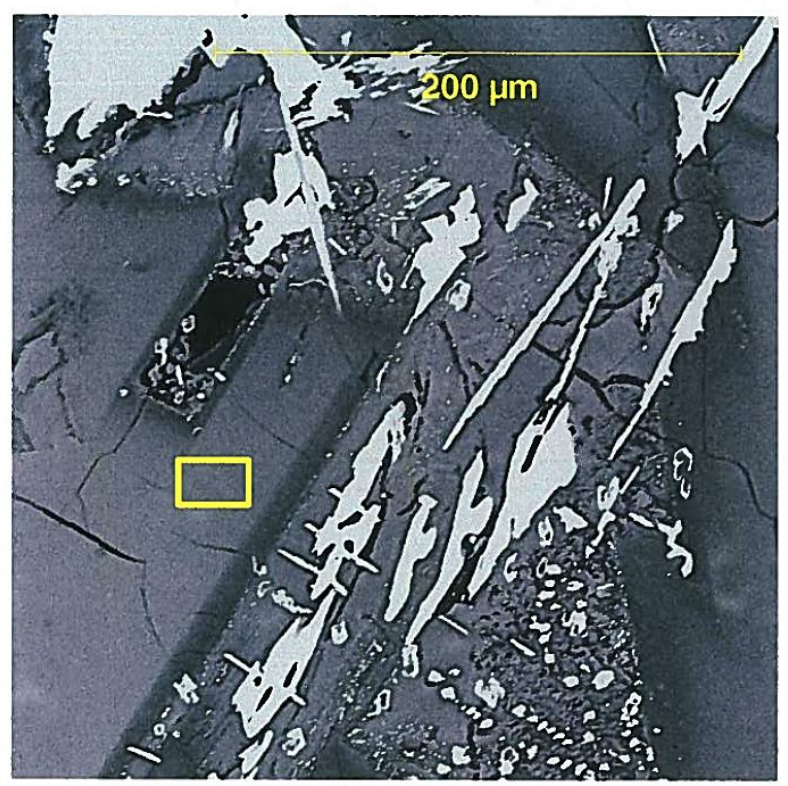

accelerating voltage $=20.0 \mathrm{kV} \quad$ working distance $=17.5 \mathrm{~mm}$

spot size $=38.9 \%$

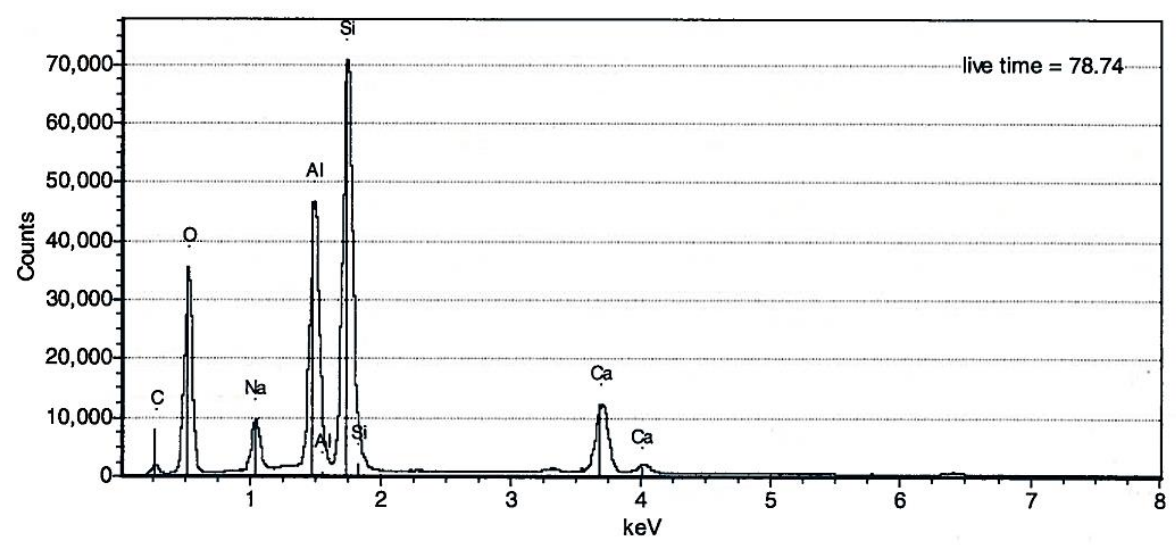


Basalt (sample WR11)

\section{USGS CVO ASPEX EXpress}

$12 / 26 / 2013$

C:IDocuments and SettingsVAll UsersIDocuments\ASPEXLizITygh Valley SamplesIWR11_13.TIF

01:43:17 PN

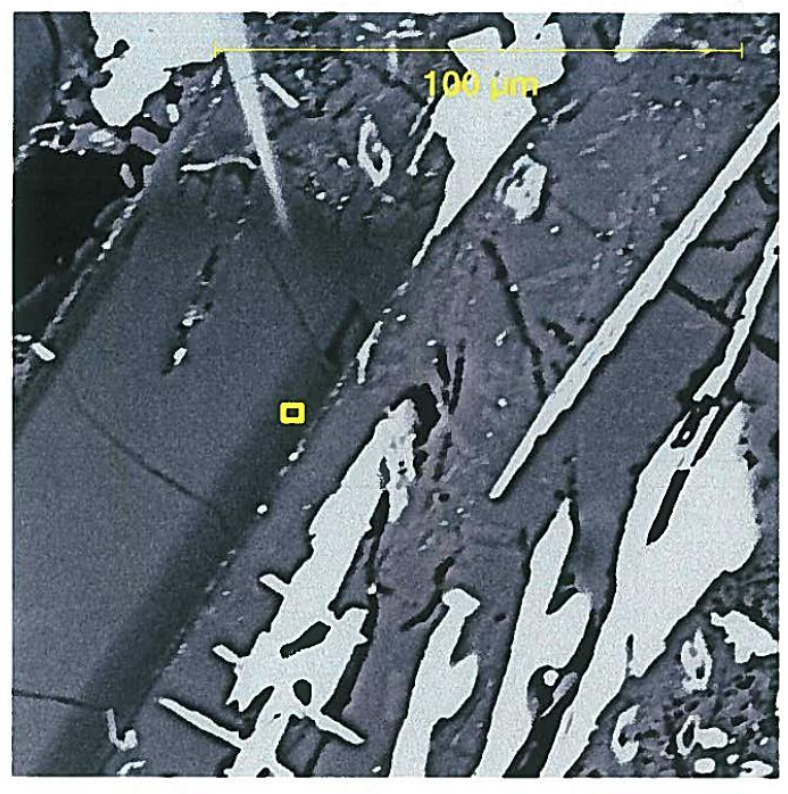

accelerating voltage $=20.0 \mathrm{kV}$

working distance $=17.5 \mathrm{~mm}$

spot size $=38.9 \%$

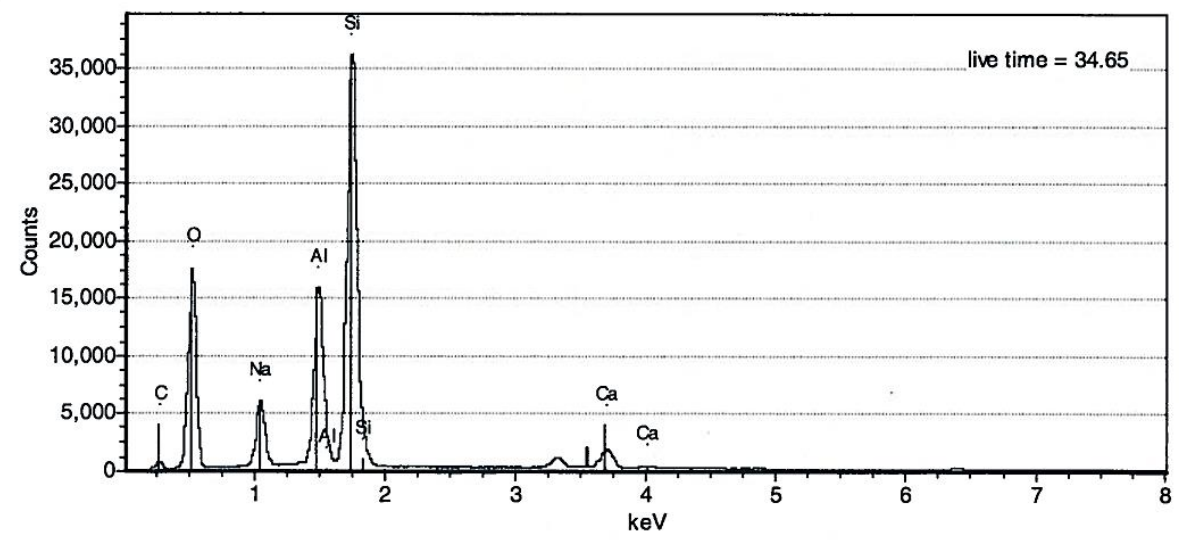


Basalt (sample WR11)

\section{USGS CVO ASPEX EXpress}

$12 / 26 / 2013$

C:IDocuments and Settings\AII UsersIDocumentsLSSPEXLizITygh Valley SamplesIWR11_4.TIF

01:07:01 PN
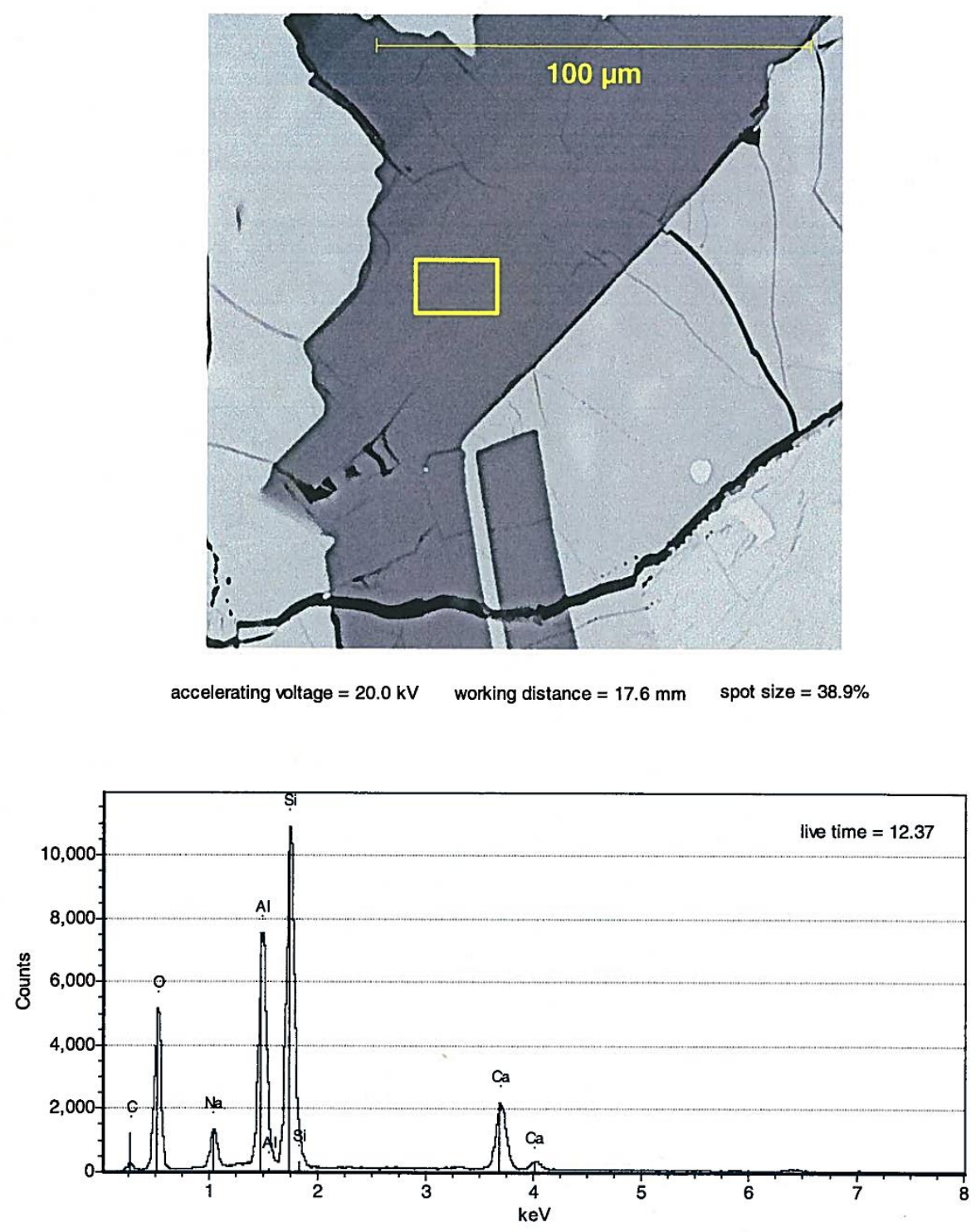
Basalt (sample WR11)

\section{USGS CVO ASPEX EXpress}

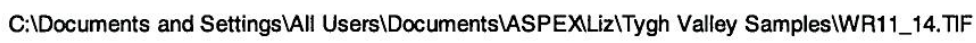

$12 / 26 / 2013$

01:46:18 PA

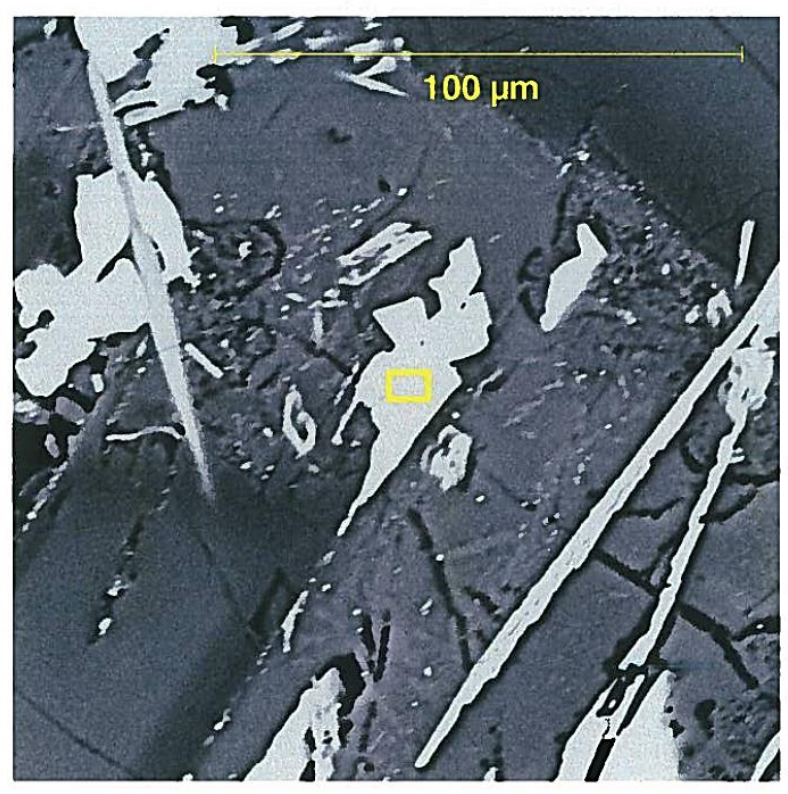

accelerating voltage $=20.0 \mathrm{kV}$

working distance $=17.5 \mathrm{~mm}$

spot size $=38.9 \%$

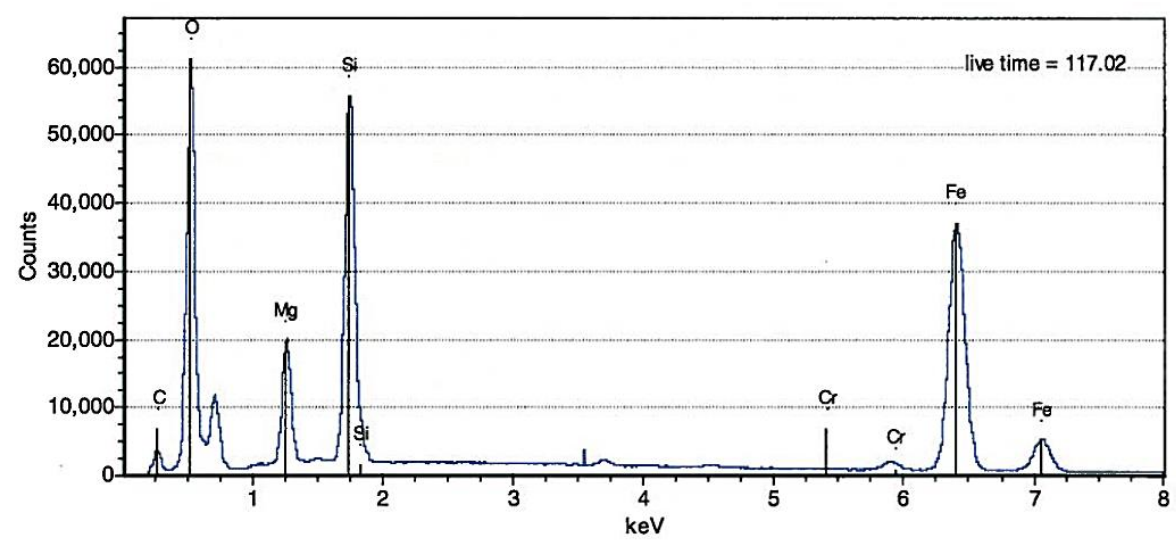


Basalt (sample WR11)

\section{USGS CVO ASPEX EXpress}

$12 / 26 / 2013$

C:IDocuments and Settings\All UsersIDocuments\ASPEXLizITygh Valley SamplesIWR11_18.ThF

02:11:56 PN

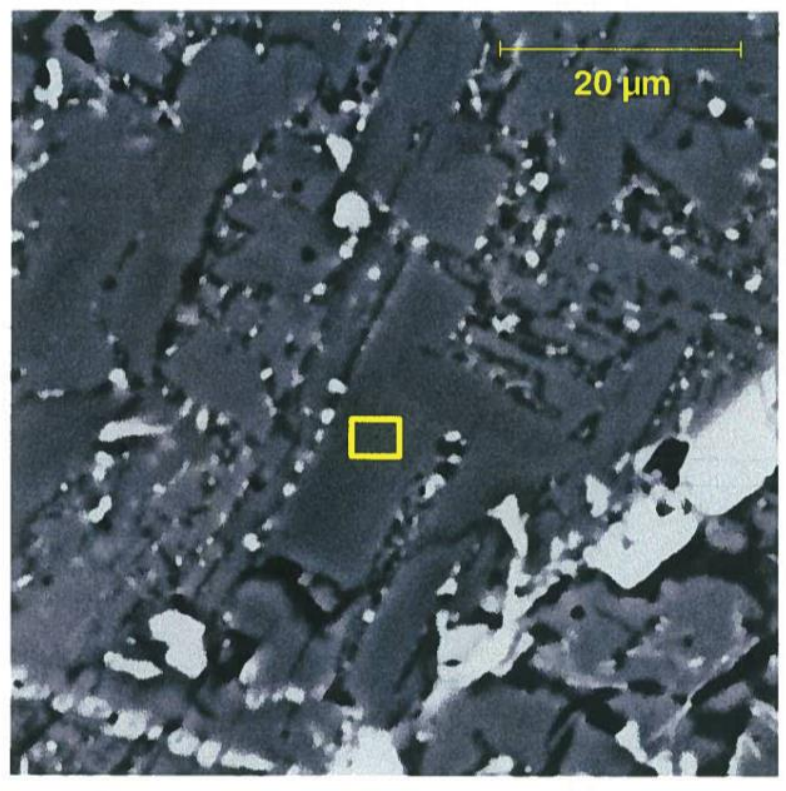

accelerating voltage $=20.0 \mathrm{kV}$

working distance $=17.4 \mathrm{~mm}$

spot size $=38.9 \%$

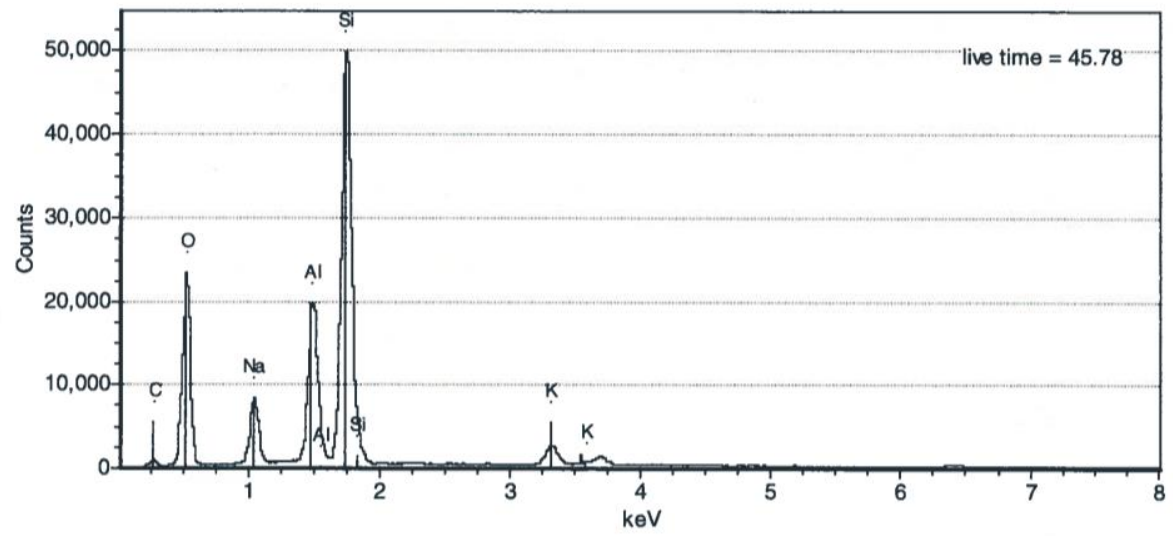


Andesites (sample V1)

\section{USGS CVO ASPEX EXpress}

$12 / 26 / 2013$

C:IDocuments and Settings\All UsersIDocuments\ASPEXLizITygh Valley SamplesIV1_16.TIF
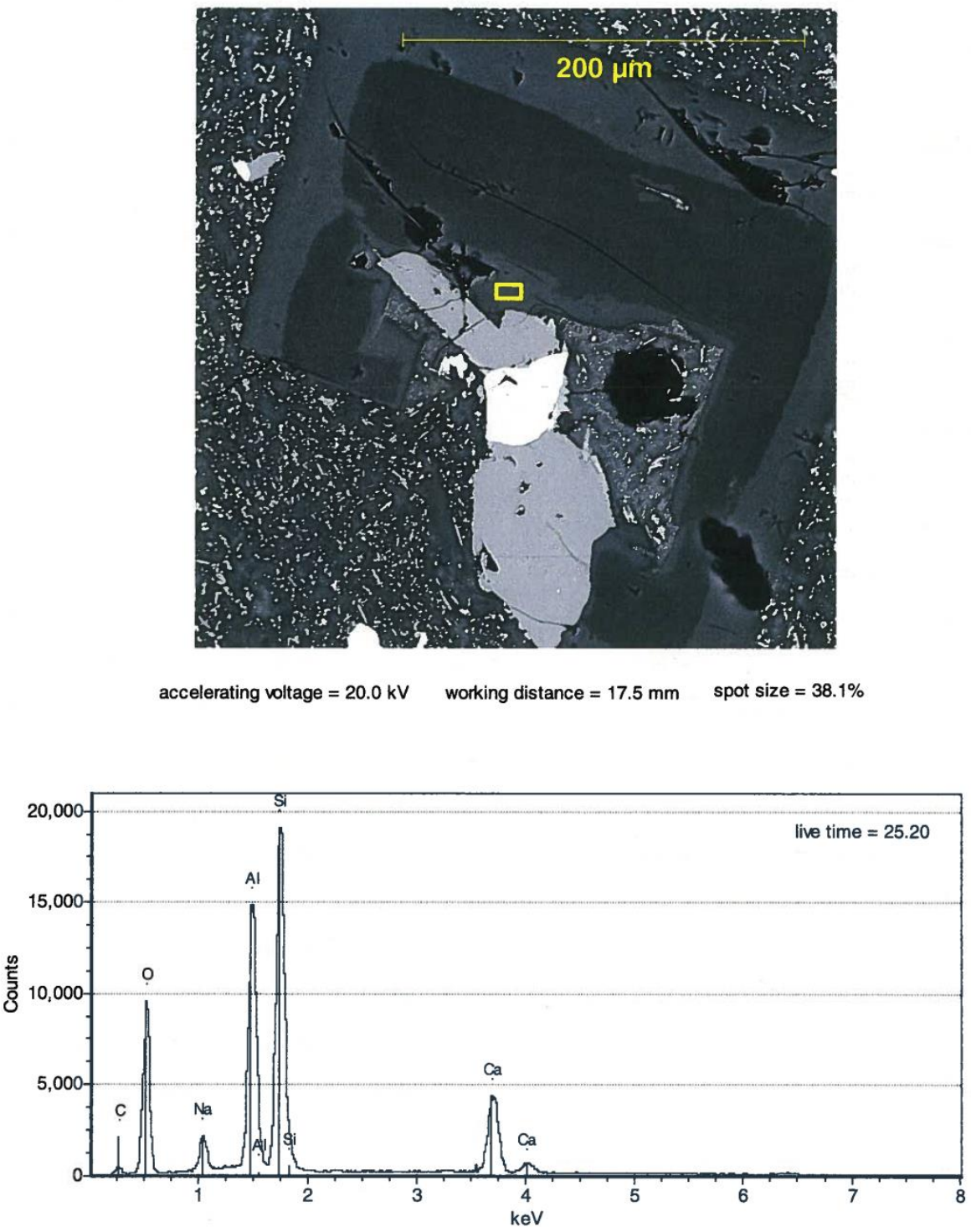
Andesites (sample V1)

\section{USGS CVO ASPEX EXpress}

C:IDocuments and SettingsVAll UsersIDocumentsVASPEXLizITygh Valley SamplesIV1_14.TIF

$12 / 26 / 2013$

03:59:17 PN

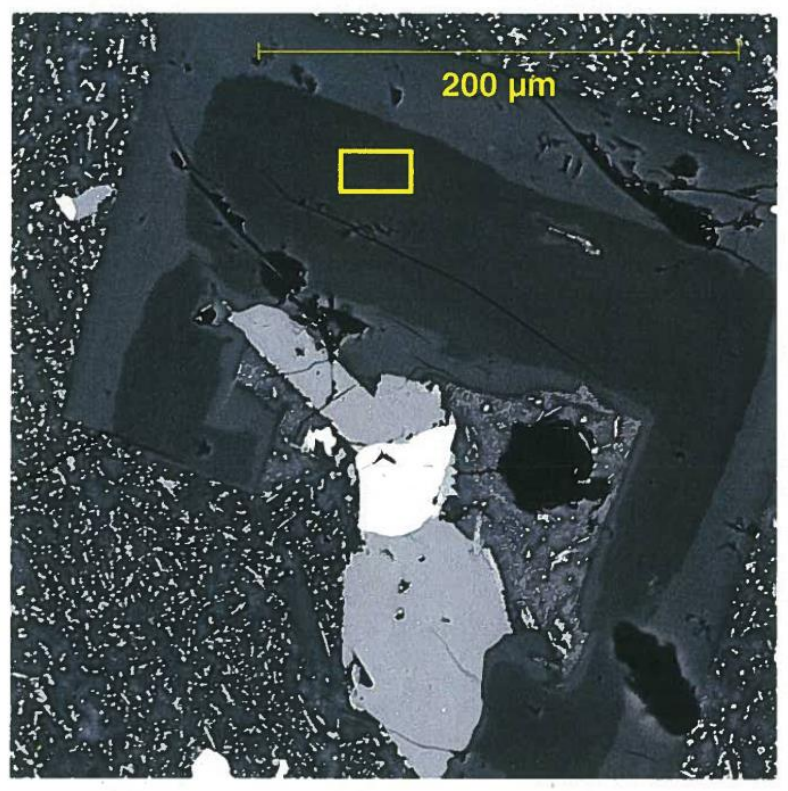

accelerating voltage $=20.0 \mathrm{kV}$

working distance $=17.5 \mathrm{~mm}$

spot size $=38.1 \%$

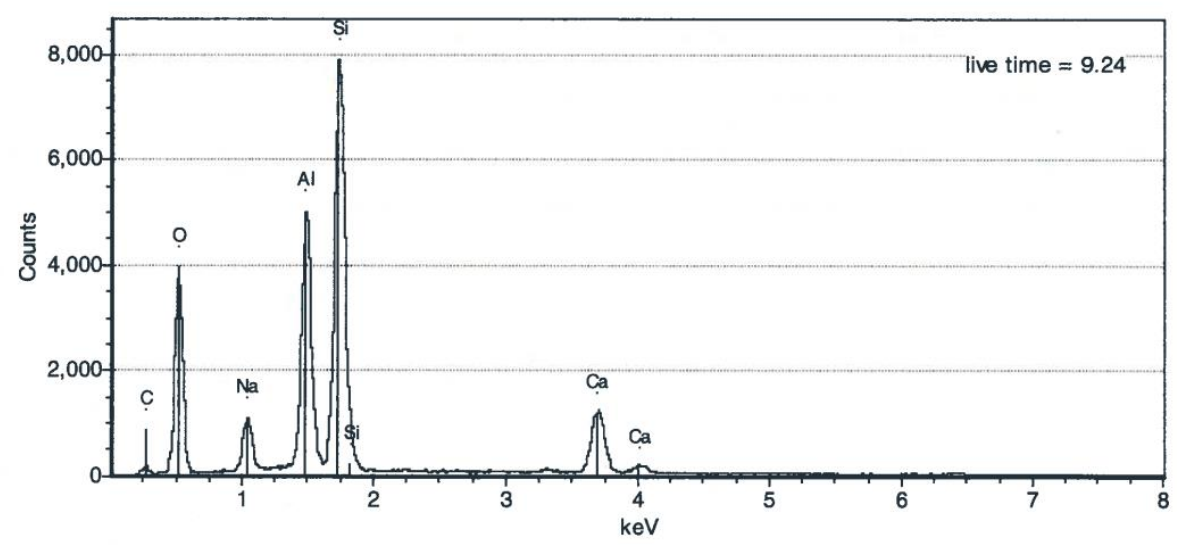


Andesites (sample V1)

\section{USGS CVO ASPEX EXpress}

C:IDocuments and Settings\All UsersIDocuments\ASPEXLizITygh Valley SamplesIV1_13.TIF

$12 / 26 / 2013$

03:58:31 PA

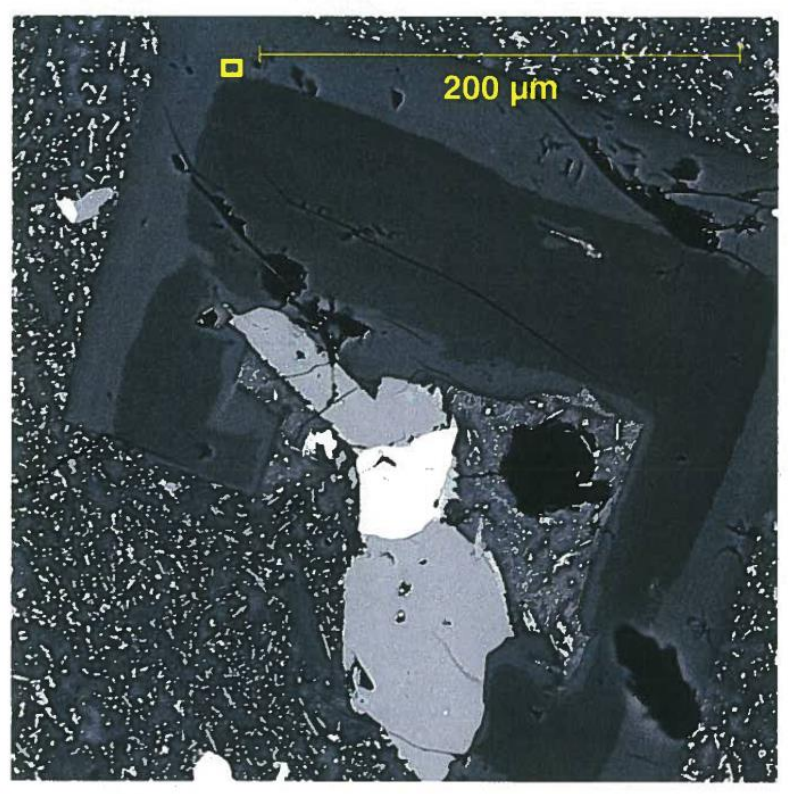

accelerating voltage $=20.0 \mathrm{kV}$

working distance $=17.5 \mathrm{~mm}$

spot size $=38.1 \%$

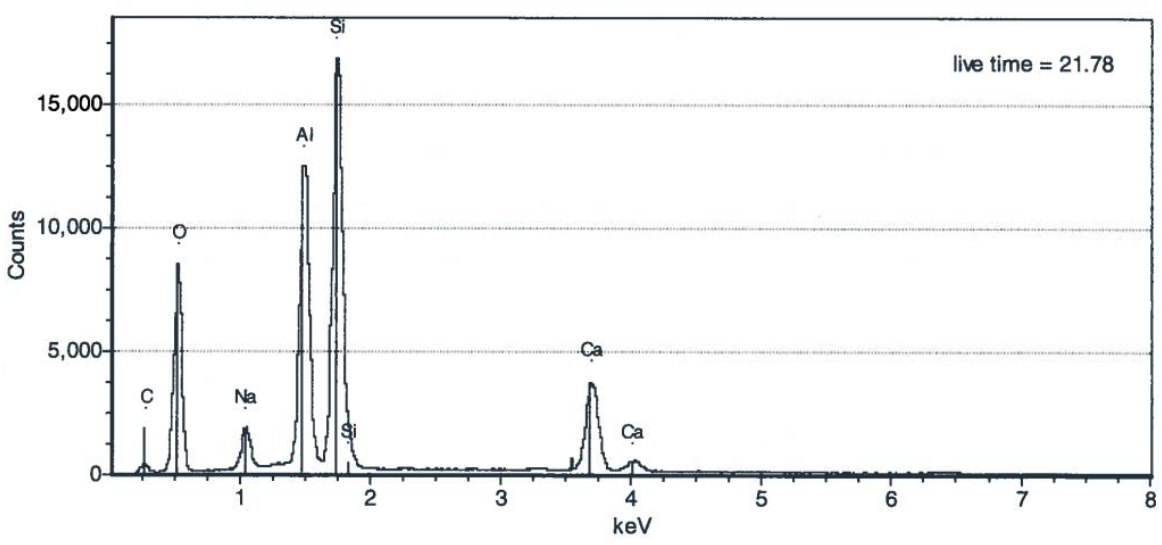


Andesites (sample V1)

USGS CVO ASPEX EXpress

$12 / 26 / 2013$

C:IDocuments and Settings\All Users|Documents\ASPEXLiz|Tygh Valley SamplesIV1_15.TIF

04:00:40 PN

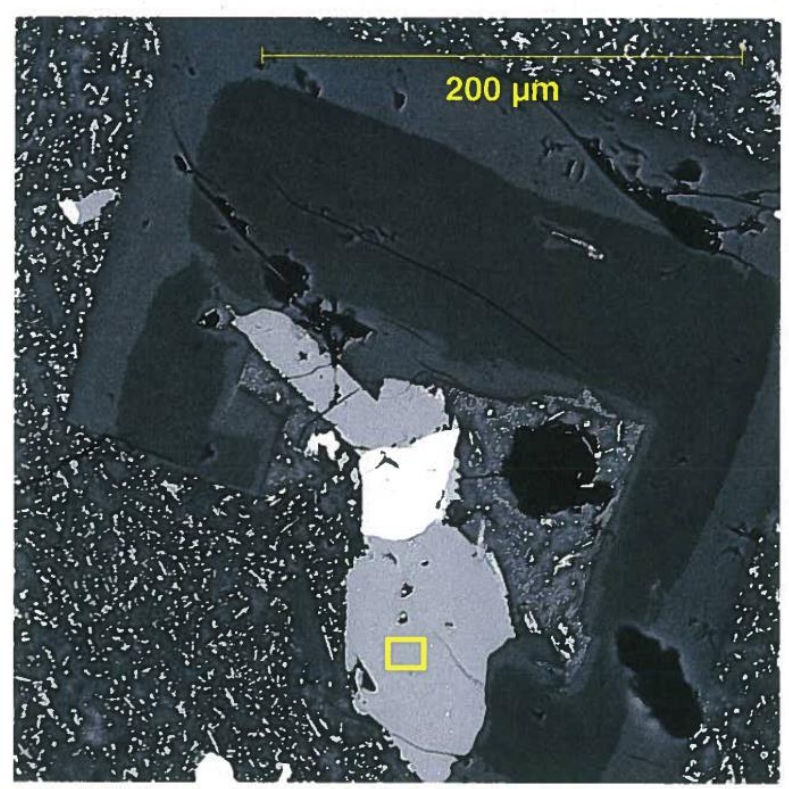

accelerating voltage $=20.0 \mathrm{kV} \quad$ working distance $=17.5 \mathrm{~mm} \quad$ spot size $=38.1 \%$

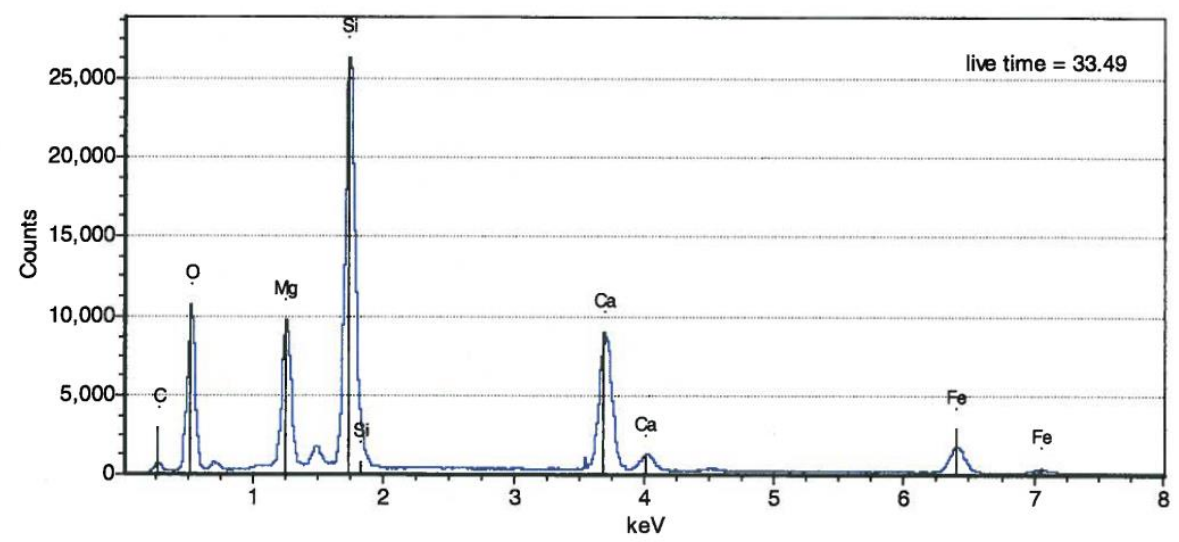


Andesites (sample V1)

\section{USGS CVO ASPEX EXpress}

$12 / 26 / 2013$

C:IDocuments and SettingsiAll UsersIDocuments AASPEXLizITygh Valley SamplesIV1_9.TIF

03:33:34 PN
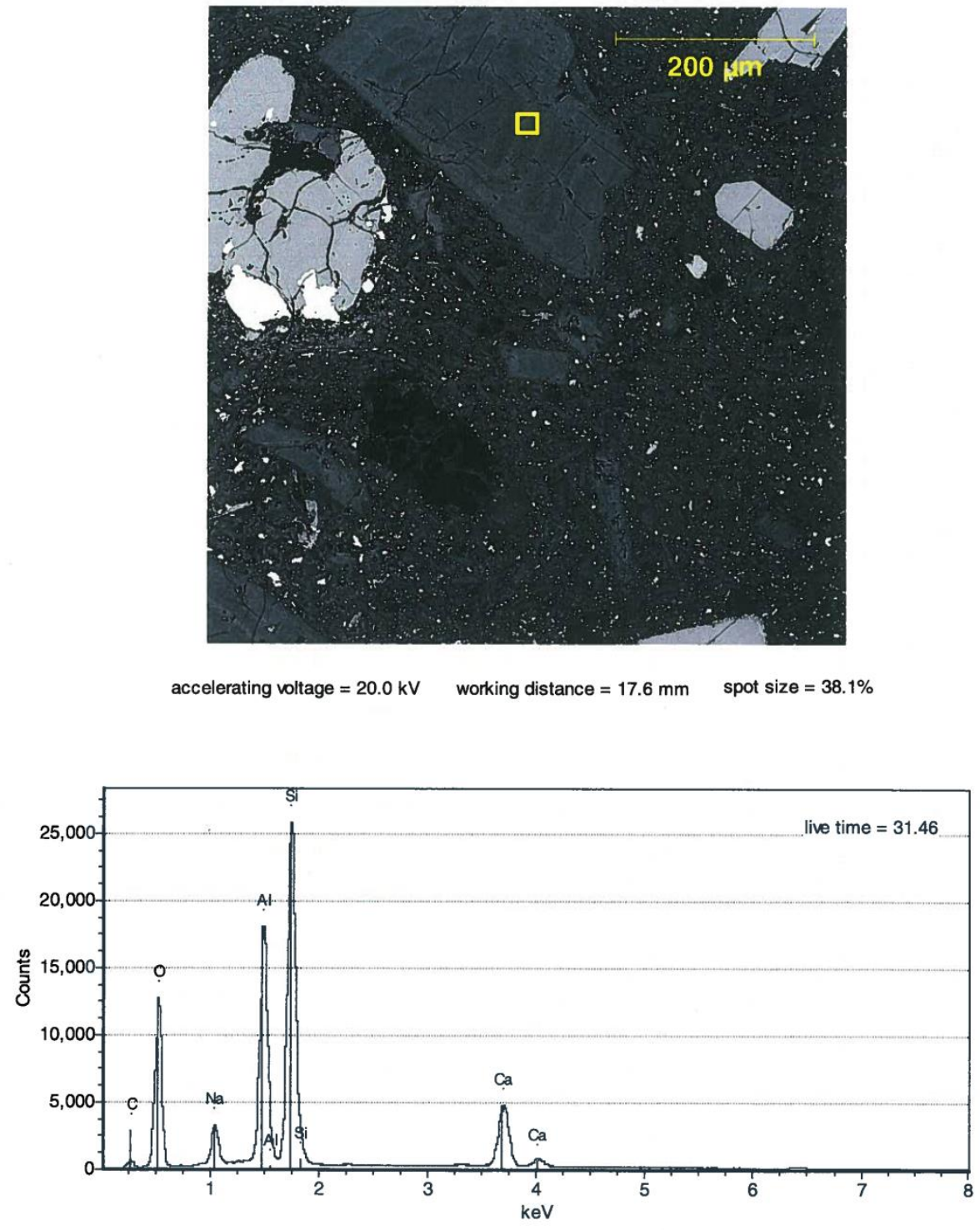
Andesites (sample V1)

\section{USGS CVO ASPEX EXpress}

C:IDocuments and Settings\All Users|Documents\ASPEXLizITygh Valley SamplesIV1_10.TIF

$12 / 26 / 2013$

03:35:54 PN

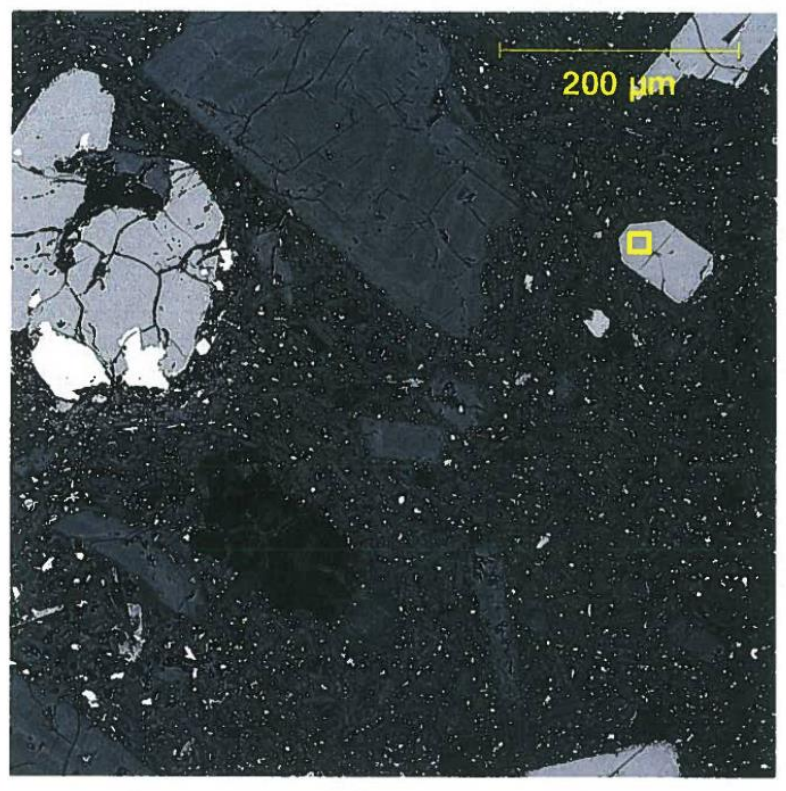

accelerating voltage $=20.0 \mathrm{kV}$

working distance $=17.6 \mathrm{~mm}$

spot size $=38.1 \%$

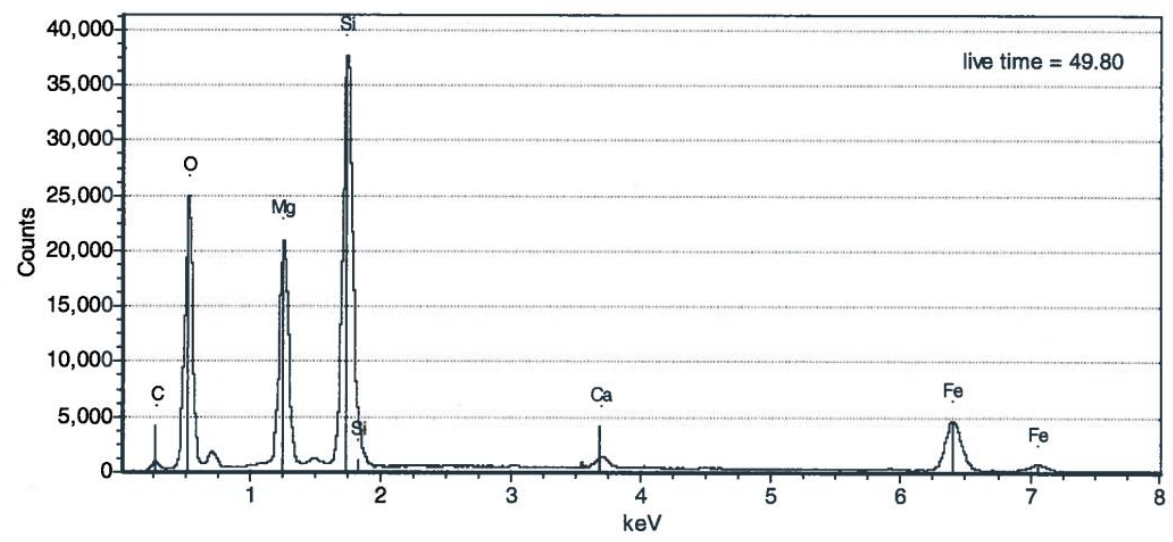


Andesites (sample V1)

\section{USGS CVO ASPEX EXpress}

$12 / 26 / 2013$

C:IDocuments and SettingsVAll UsersIDocuments\ASPEXLizITygh Valley SamplesIV1_11.TIF

03:43:38 PN

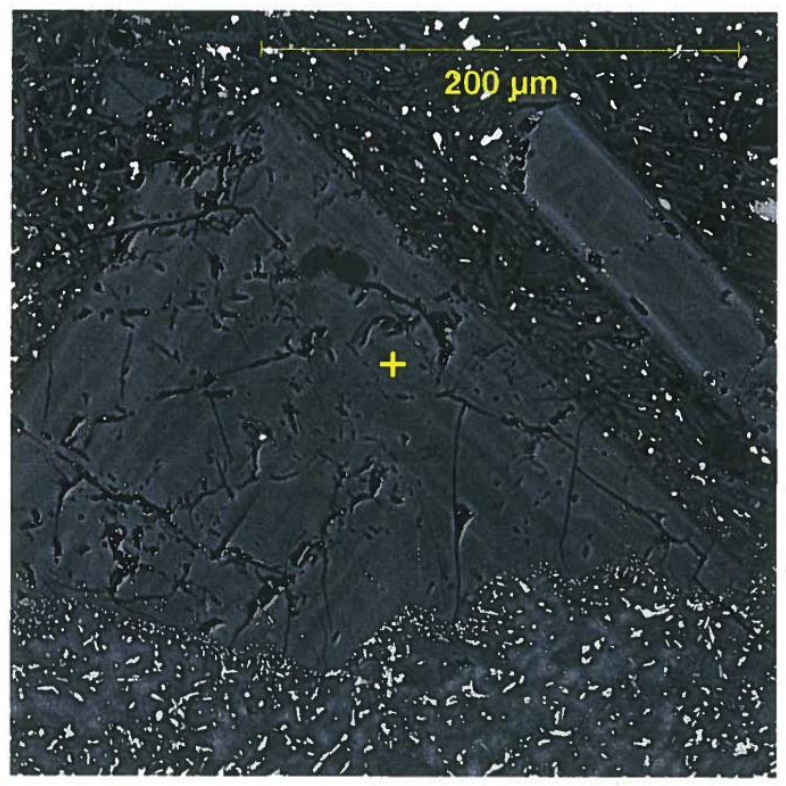

accelerating voltage $=20.0 \mathrm{kV}$

working distance $=17.6 \mathrm{~mm}$

spot size $=38.1 \%$

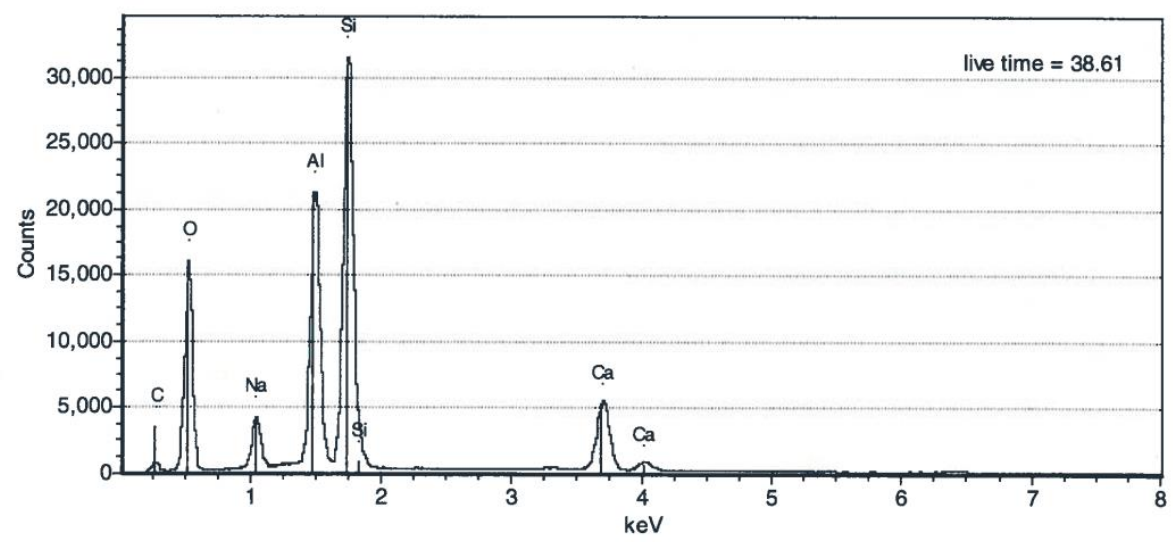


Andesites (sample V1)

USGS CVO ASPEX EXpress

$12 / 26 / 2013$

C:IDocuments and SettingsVAll UsersIDocumentsVASPEXLiz|Tygh Valley SamplesIV1_4.TIF

03:10:59 PA

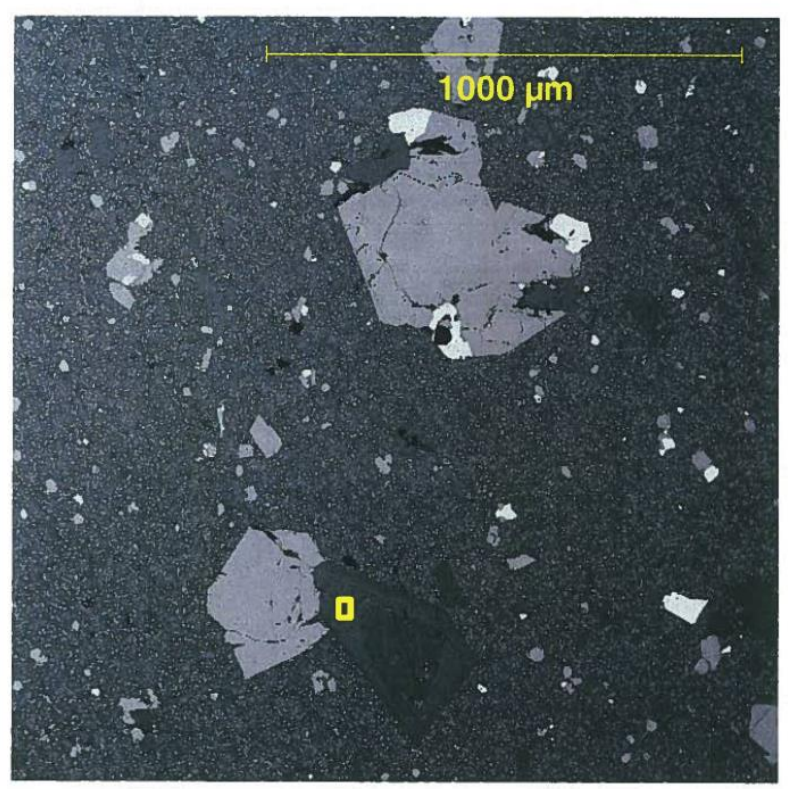

accelerating voltage $=20.0 \mathrm{kV} \quad$ working distance $=17.6 \mathrm{~mm}$

spot size $=38.9 \%$

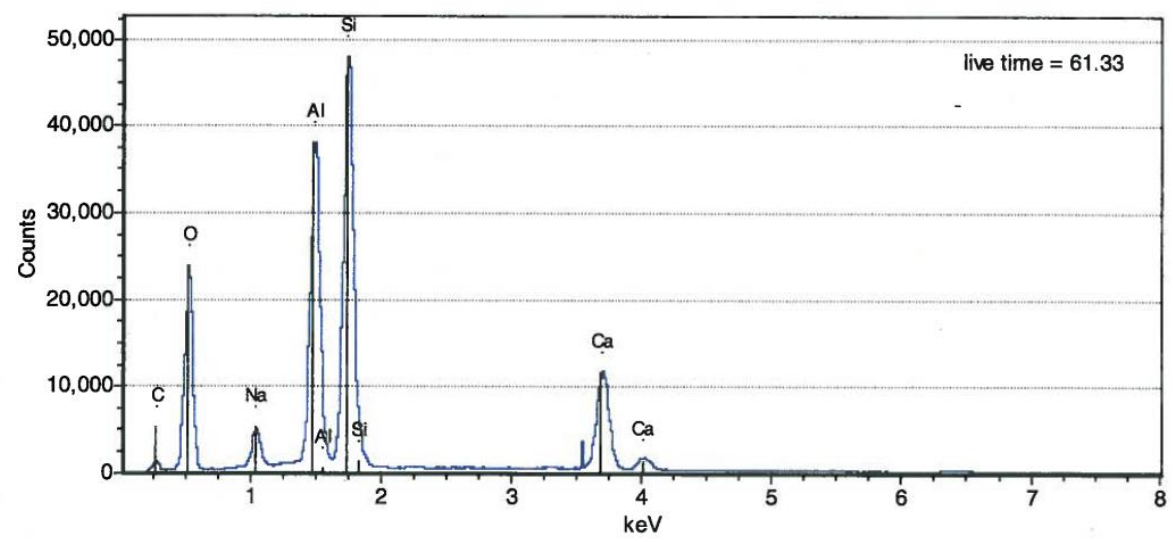


Andesites (sample V1)

\section{USGS CVO ASPEX EXpress}

$12 / 26 / 2013$

C:IDocuments and Settings\AII UsersIDocuments\ASPEXILizITygh Valley SamplesIV1_3.TFF

03:09:24 PN

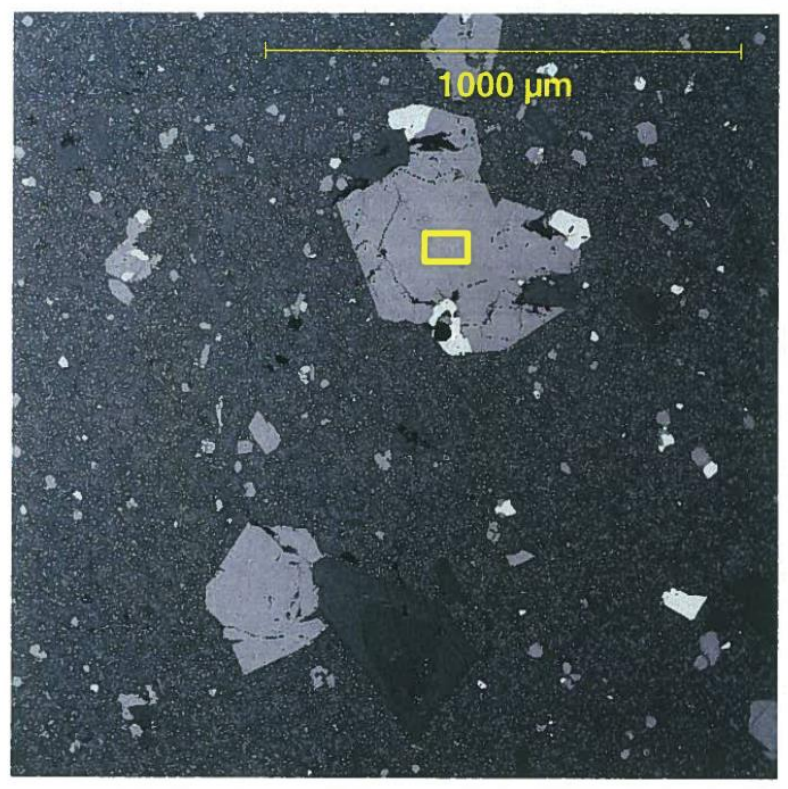

accelerating voltage $=20.0 \mathrm{kV}$

working distance $=17.6 \mathrm{~mm}$

spot size $=38.9 \%$

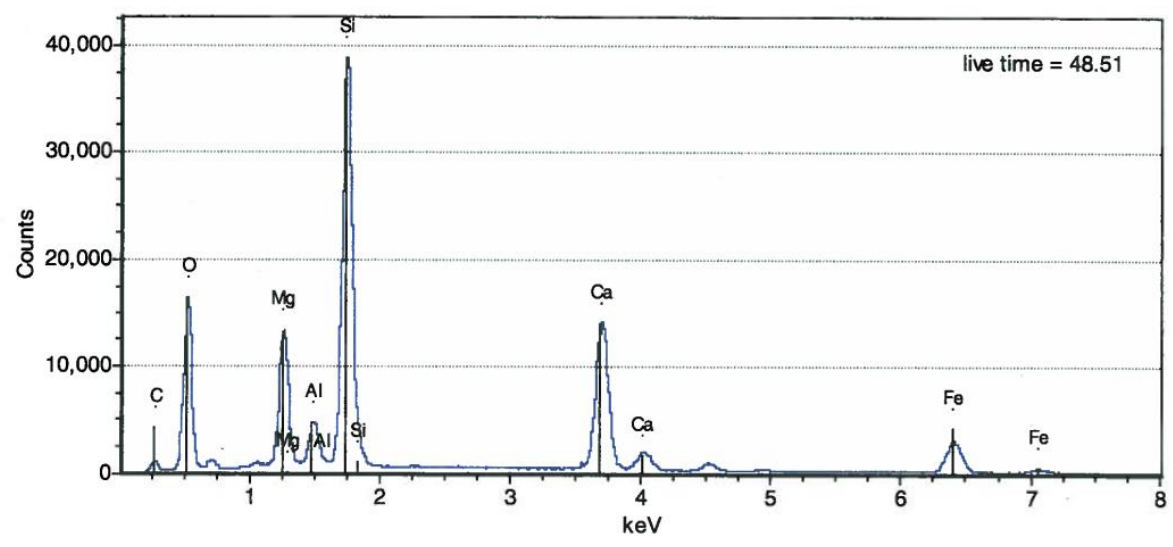


Andesites (sample V1)

\section{USGS CVO ASPEX EXpress}

$12 / 26 / 2013$

C:IDocuments and Settings \AII Users $\mid$ Documents $\backslash A S P E X L i z \mid T y g h$ Valley SamplesIV1_1.TFF

02:59:52 PN

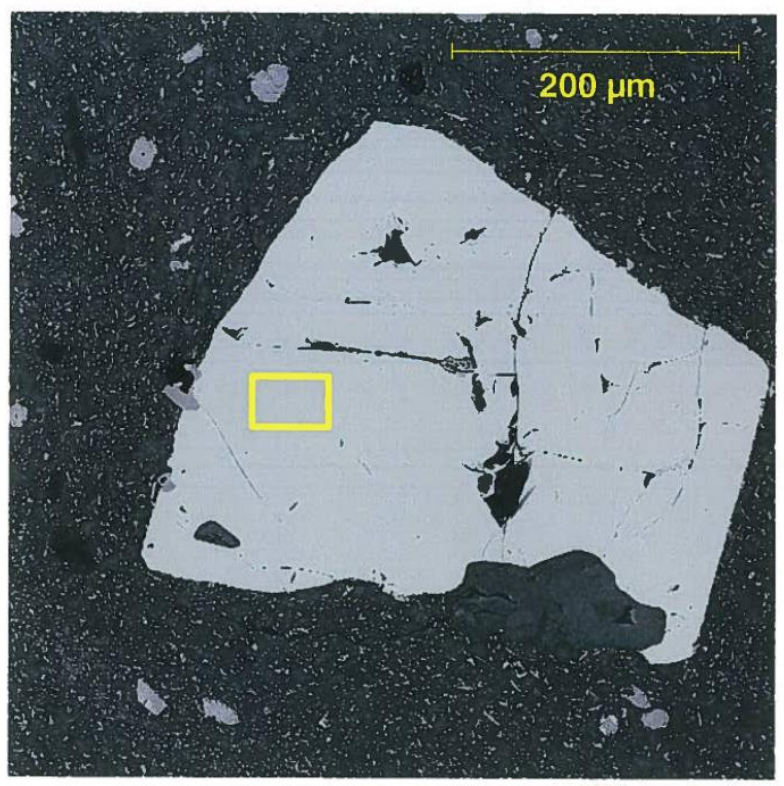

accelerating voltage $=20.0 \mathrm{kV}$

working distance $=17.5 \mathrm{~mm}$

spot size $=38.9 \%$

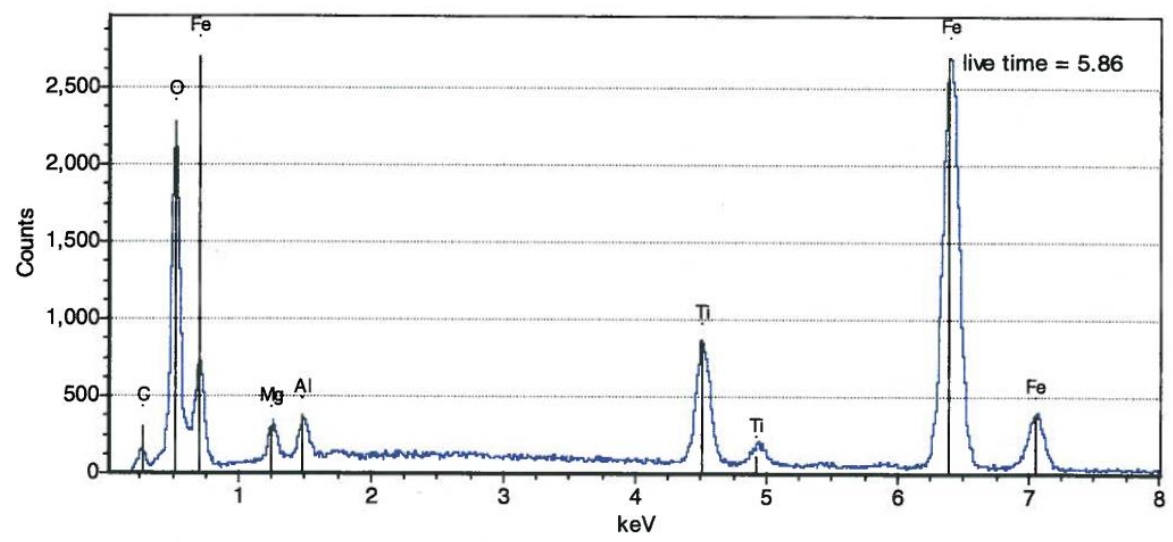


Andesite (sample S12-6A)

\section{USGS CVO ASPEX EXpress}

$12 / 27 / 2013$

C:IDocuments and Settings $\backslash A l l$ UsersIDocuments\ASPEXLizITygh Valley SamplesIS12_6A_13.TIF

02:31:41 PN

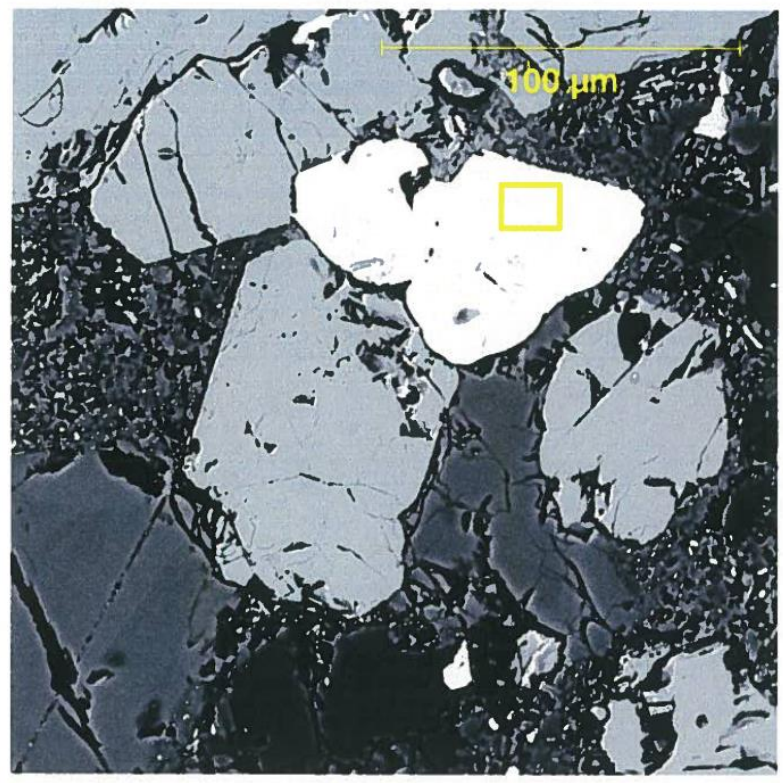

accelerating voltage $=20.0 \mathrm{kV}$

working distance $=17.6 \mathrm{~mm}$

spot size $=36.5 \%$

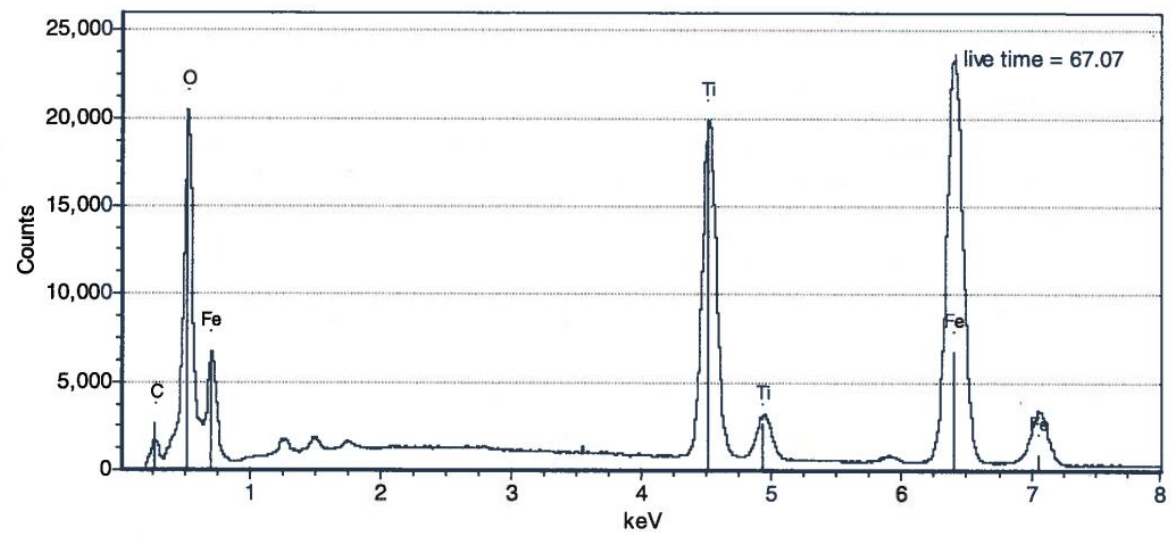


Andesite (sample S12-6A)

\section{USGS CVO ASPEX EXpress}

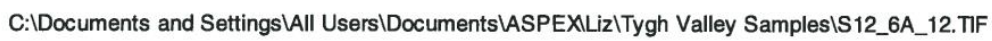

$12 / 27 / 2013$

02:29:23 PN

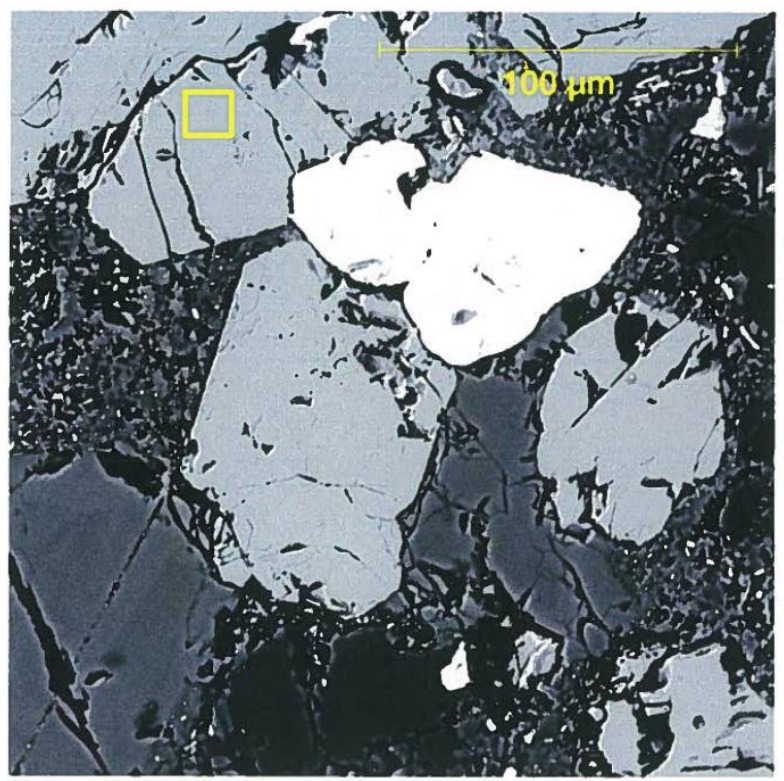

accelerating voltage $=20.0 \mathrm{kV}$

working distance $=17.6 \mathrm{~mm}$

spot size $=36.5 \%$

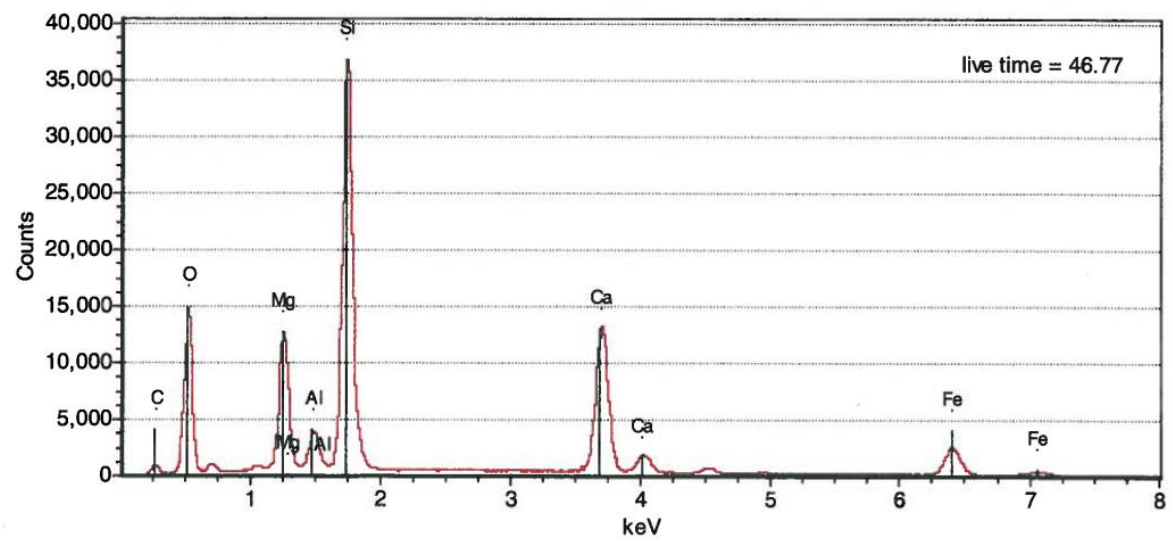


Andesite (sample S12-6A)

\section{USGS CVO ASPEX EXpress}

$12 / 27 / 2013$

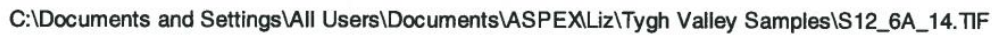

02:33:54 PN
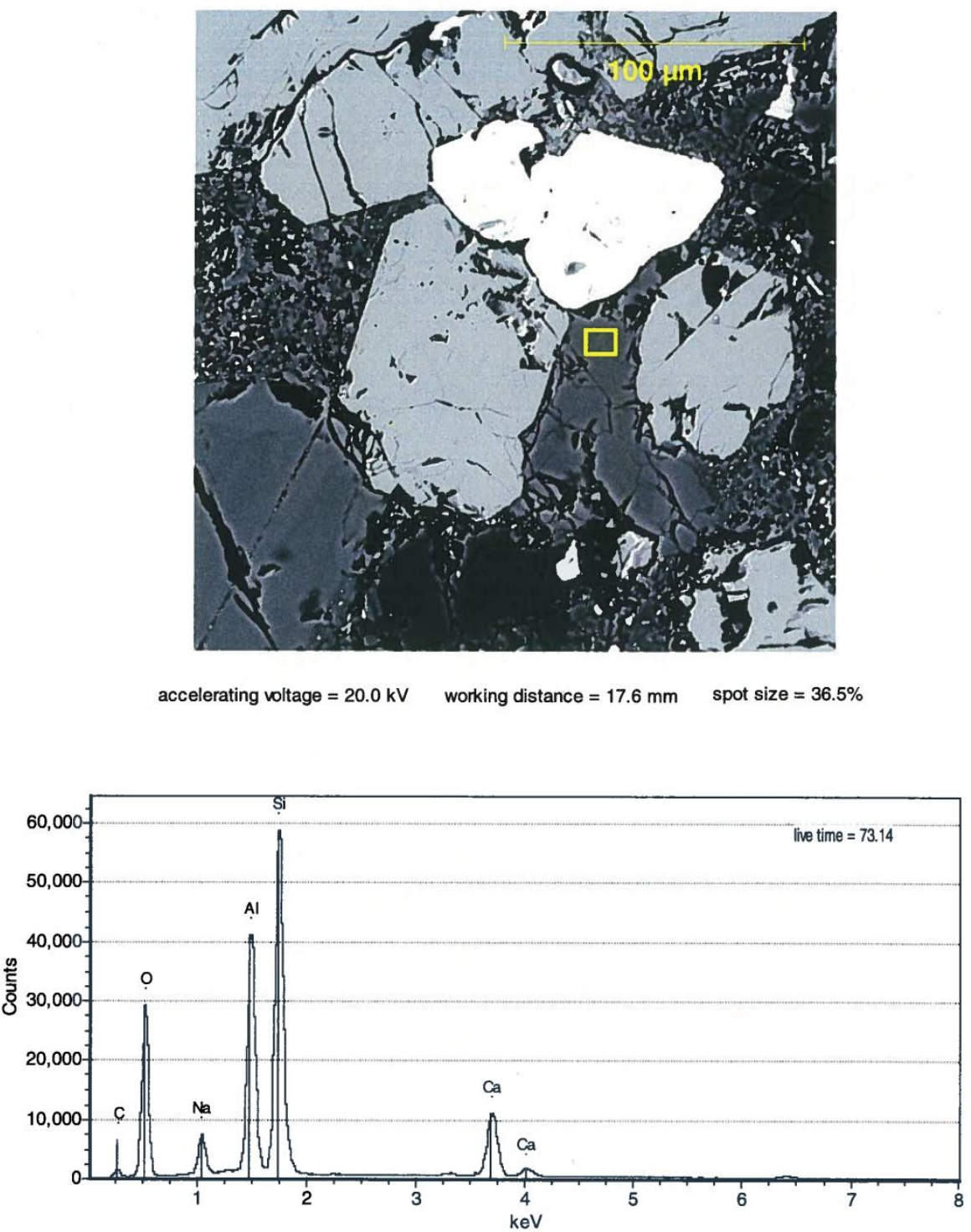
Andesite (sample S12-6A)

\section{USGS CVO ASPEX EXpress}

C:IDocuments and Settings\All UsersIDocumentsVASPEXLizITygh Valley SamplesIS12_6A_15.TFF

$12 / 27 / 2013$

02:39:44 PN

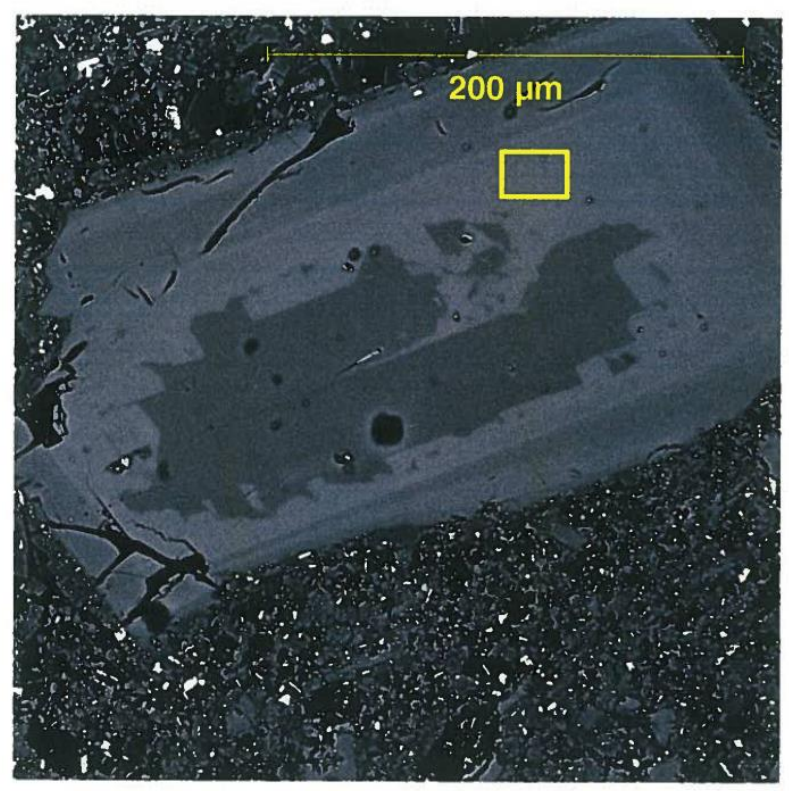

accelerating voltage $=20.0 \mathrm{kV}$

working distance $=17.7 \mathrm{~mm}$

spot size $=36.5 \%$

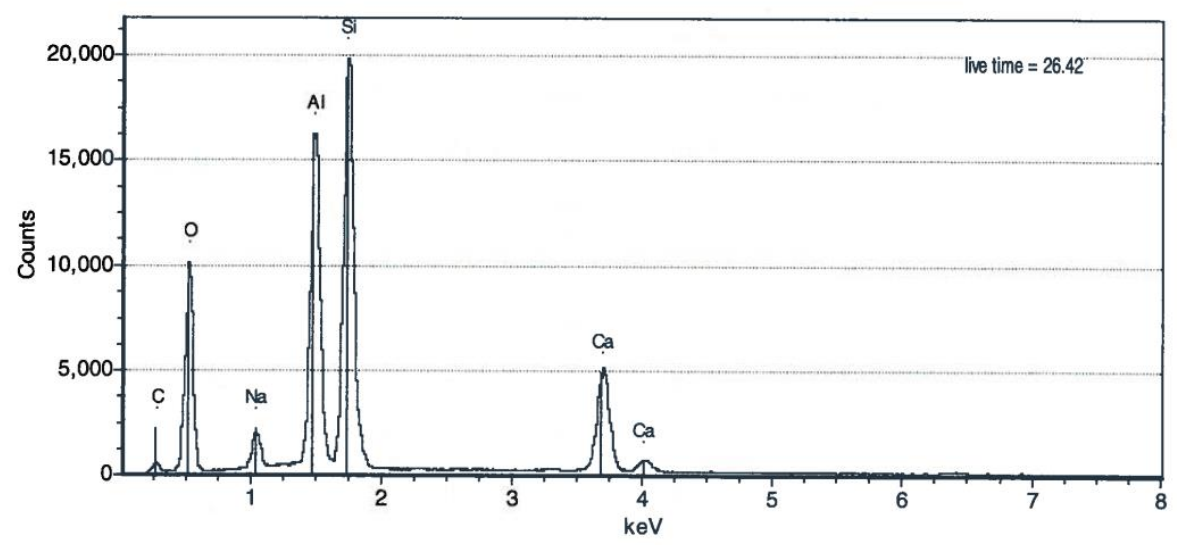


Andesite (sample S12-6A)

USGS CVO ASPEX EXpress

$12 / 27 / 2013$

C:IDocuments and Settings\All UsersIDocuments\ASPEXLizITygh Valley Samples\S12_6A_10.TF

02:19:52 PN

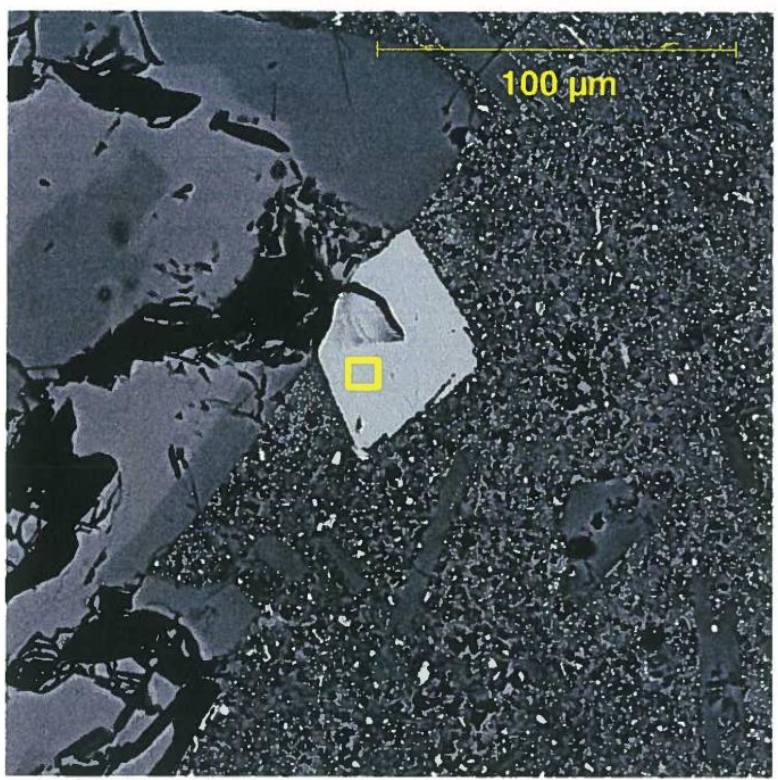

accelerating voltage $=20.0 \mathrm{kV} \quad$ working distance $=17.6 \mathrm{~mm}$

spot size $=36.5 \%$

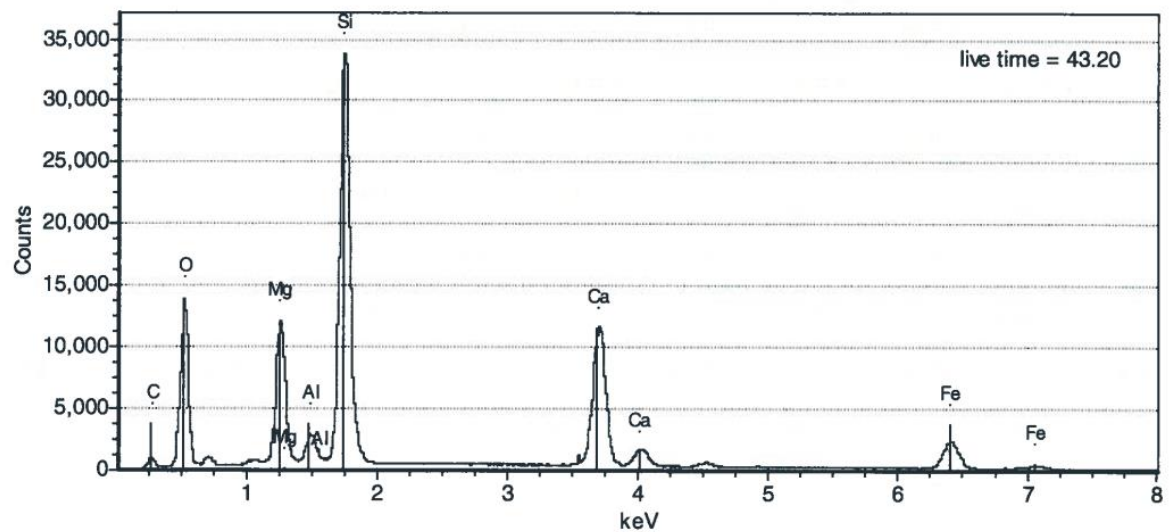


Andesite (sample S12-6A)

\section{USGS CVO ASPEX EXpress}

$12 / 27 / 2013$

C:IDocuments and Settings\All UsersIDocuments\ASPEXLizITygh Valley SamplesiS12_6A_16.TFF

02:43:38 PN
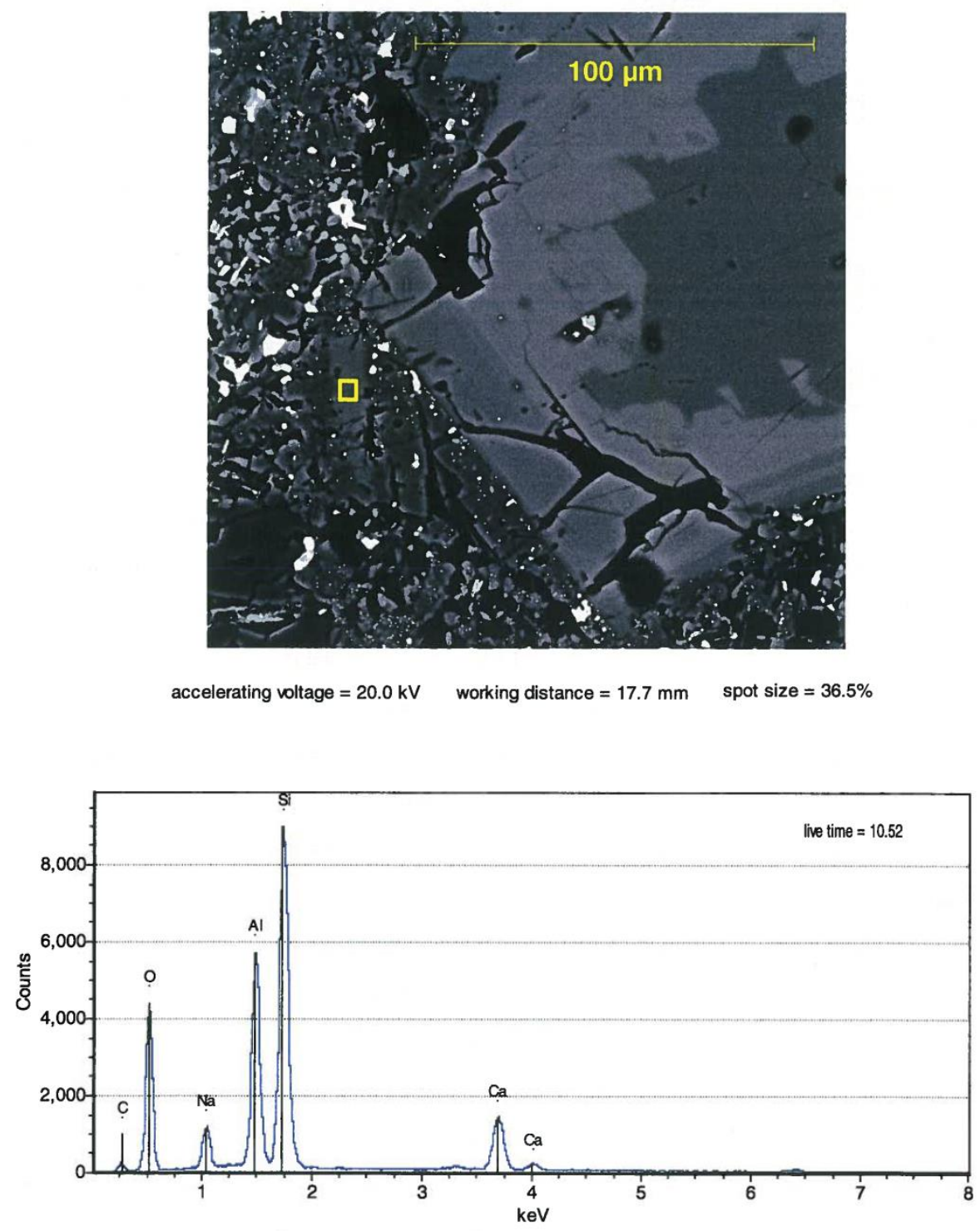
Andesite (sample S12-6A)

USGS CVO ASPEX EXpress

$12 / 27 / 2013$

C:IDocuments and Settings LAII UsersIDocuments $A$ ASPEXILizITygh Valley SamplesIS12_6A_8.TIF

02:02:49 PA

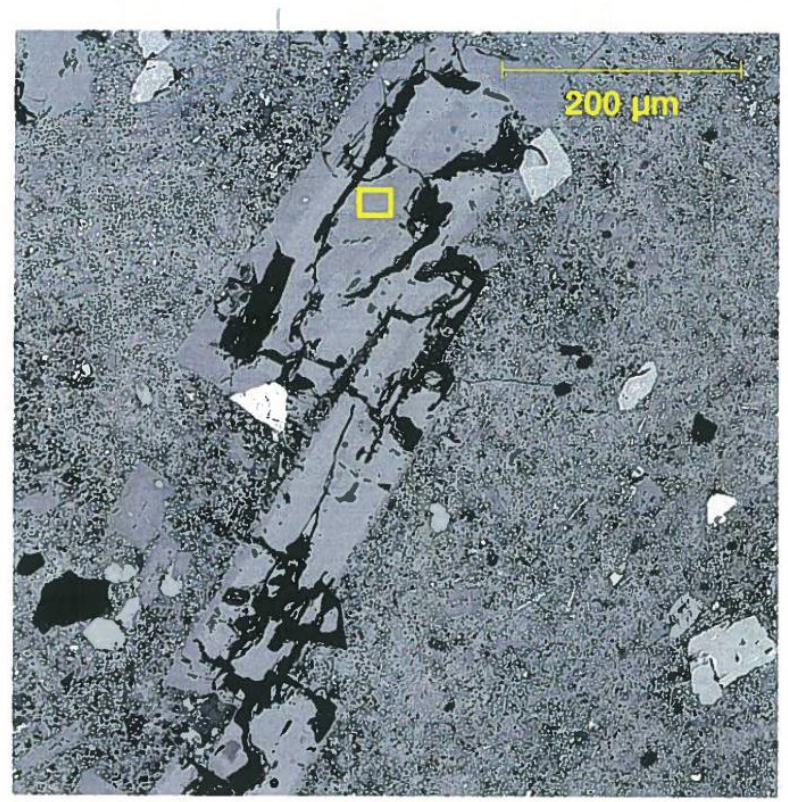

accelerating voltage $=20.0 \mathrm{kV}$

working distance $=17.6 \mathrm{~mm}$

spot size $=38.1 \%$

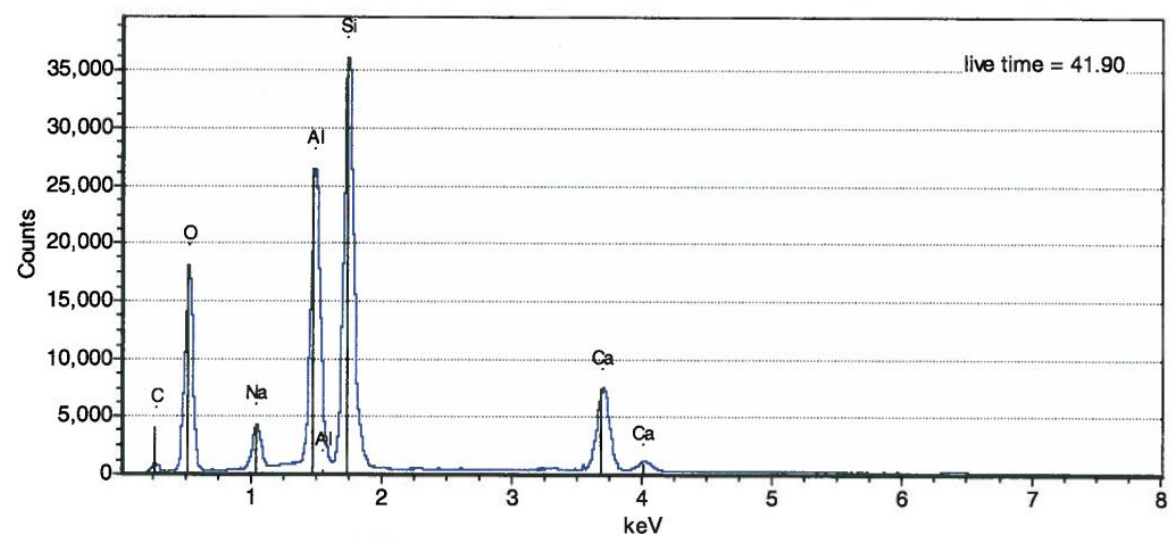


Andesite (sample S12-6A)

USGS CVO ASPEX EXpress

12/27/2013

C:IDocuments and Settings $\backslash A \mid l$ UsersIDocuments\ASPEXLiziTygh Valley SamplesIS12_6A_2.TF

01:06:45 PN



accelerating voltage $=20.0 \mathrm{kV}$

working distance $=17.7 \mathrm{~mm}$

spot size $=38.1 \%$

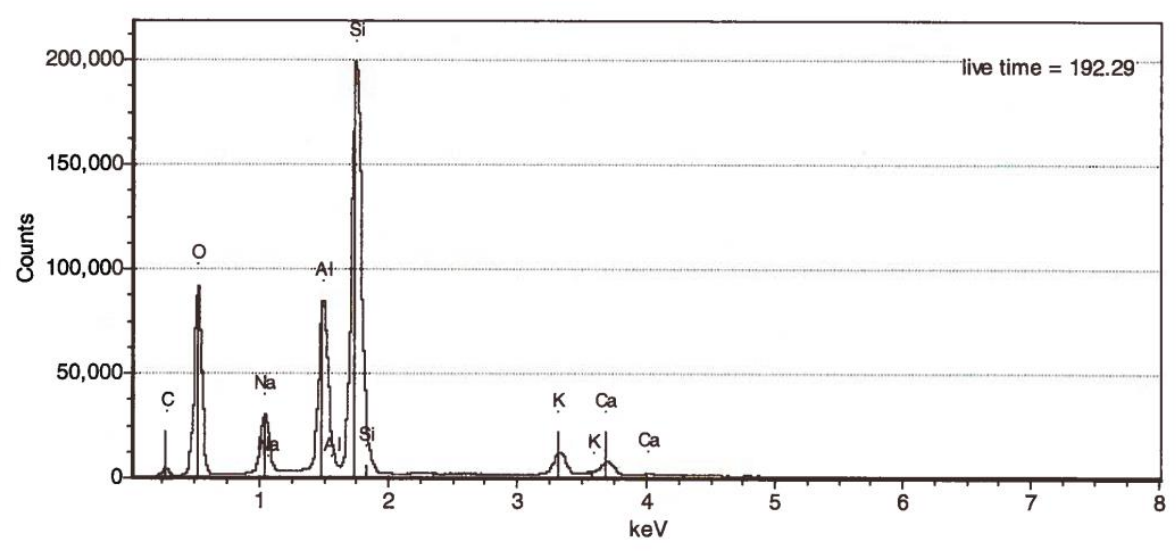


Andesite (sample S12-6A)

\section{USGS CVO ASPEX EXpress}

$12 / 27 / 2013$

C:IDocuments and Settings\AII UsersIDocumentsVASPEXLizITygh Valley SamplesIS12_6A_6.TFF

01:46:57 PN
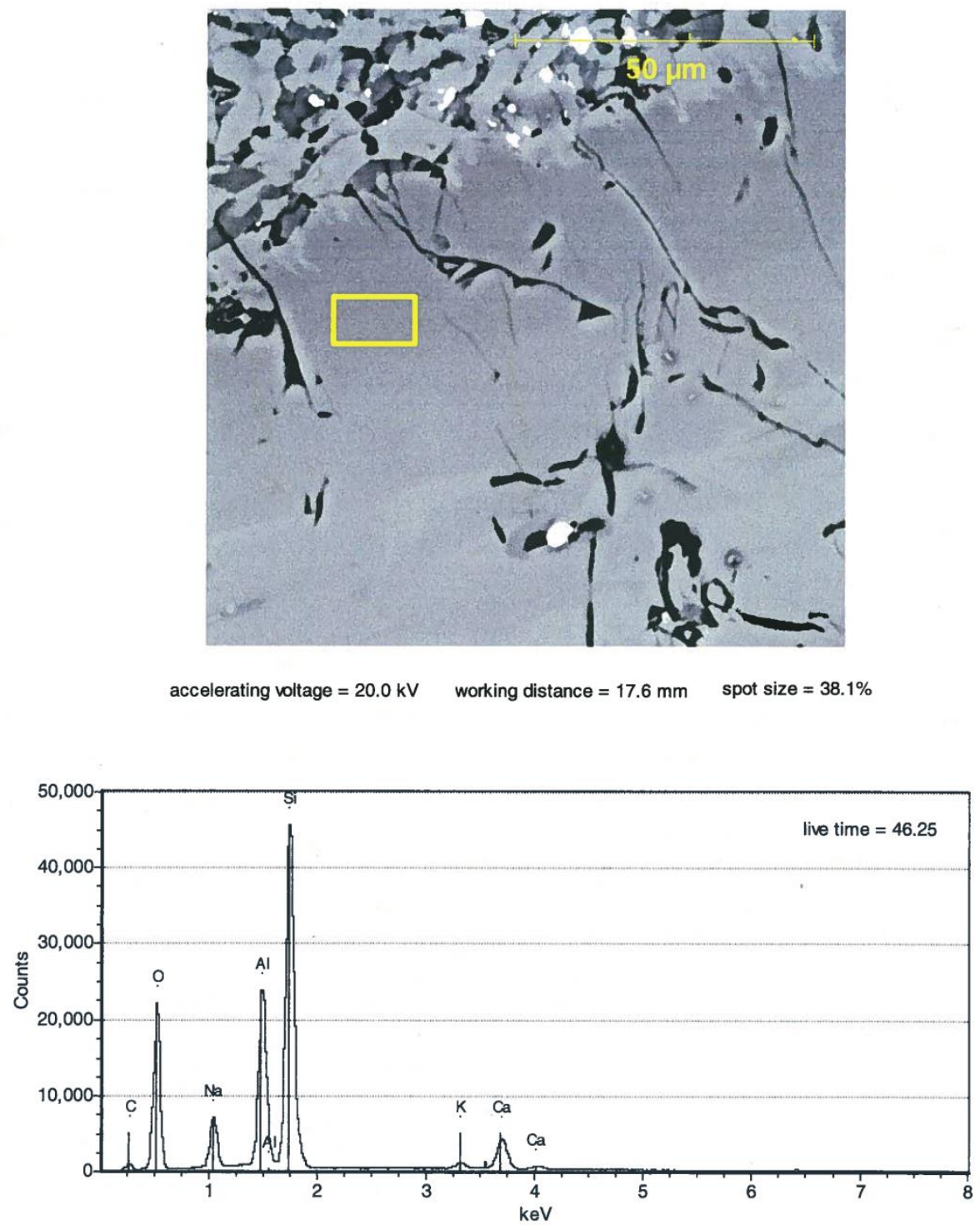
Andesite (sample S12-6A)

\section{USGS CVO ASPEX EXpress}

$12 / 27 / 2013$

C:IDocuments and SettingsLAll Users|DocumentsWASPEXLizITygh Valley SamplesIS12_6A_7.TF

01:49:31 PN
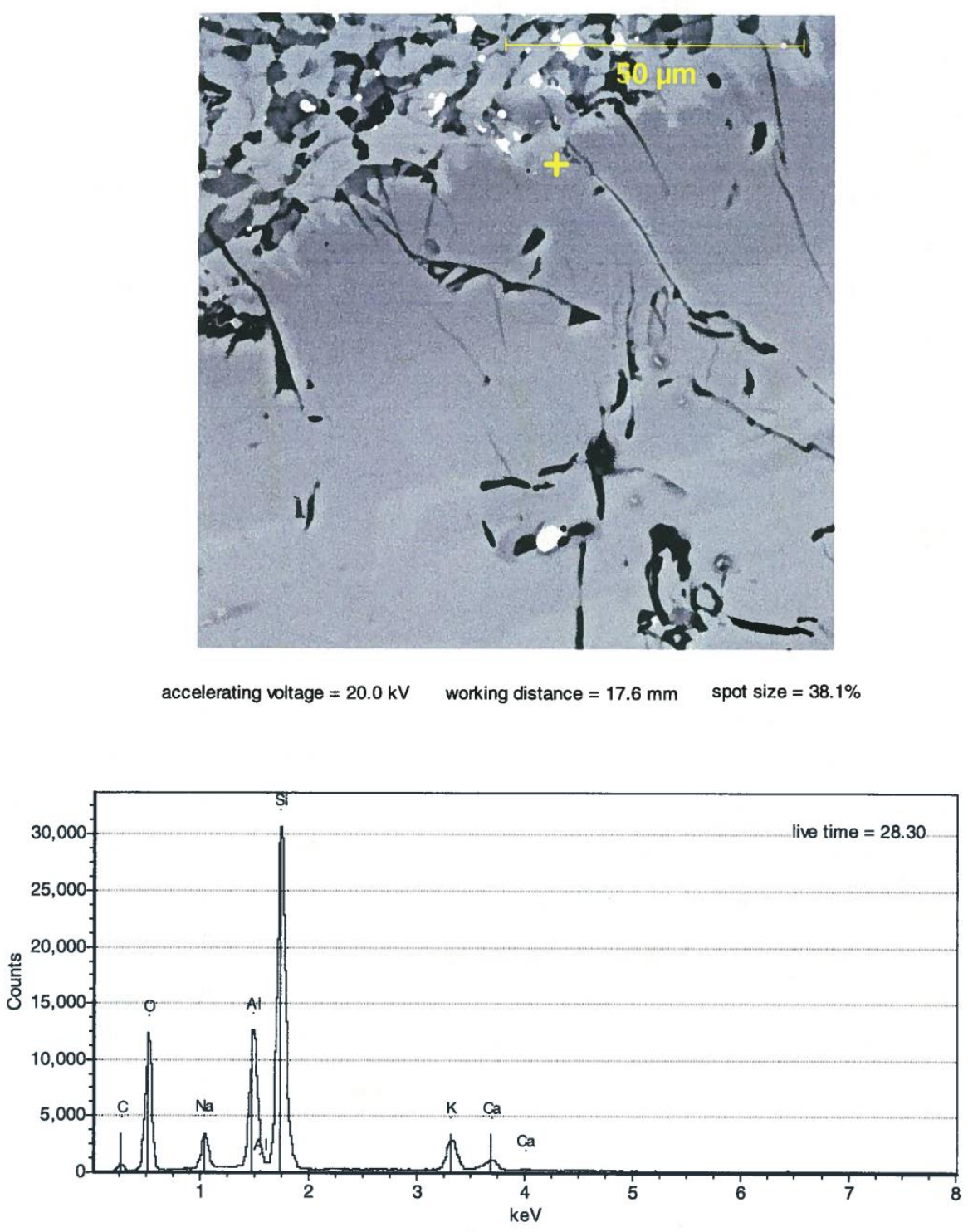
Andesite (sample S12-6A)

\section{USGS CVO ASPEX EXpress}

12/27/2013

C:IDocuments and SettingsLAII UsersIDocuments\ASPEXLiziTygh Valley SamplesIS12_6A_4.TFF

01:32:09 PN

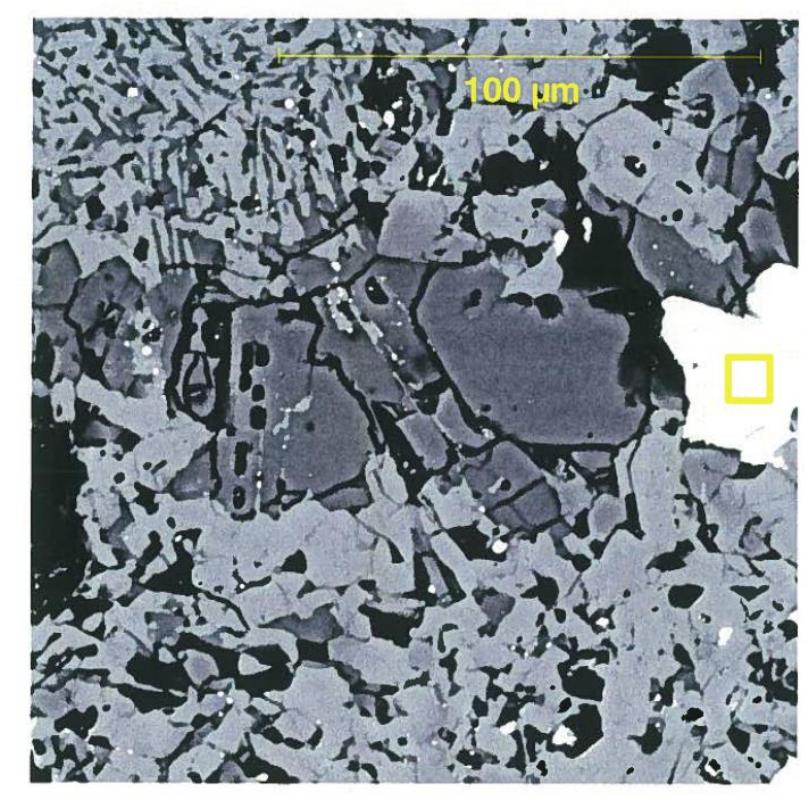

accelerating voltage $=20.0 \mathrm{kV}$

working distance $=17.5 \mathrm{~mm}$

spot size $=38.1 \%$

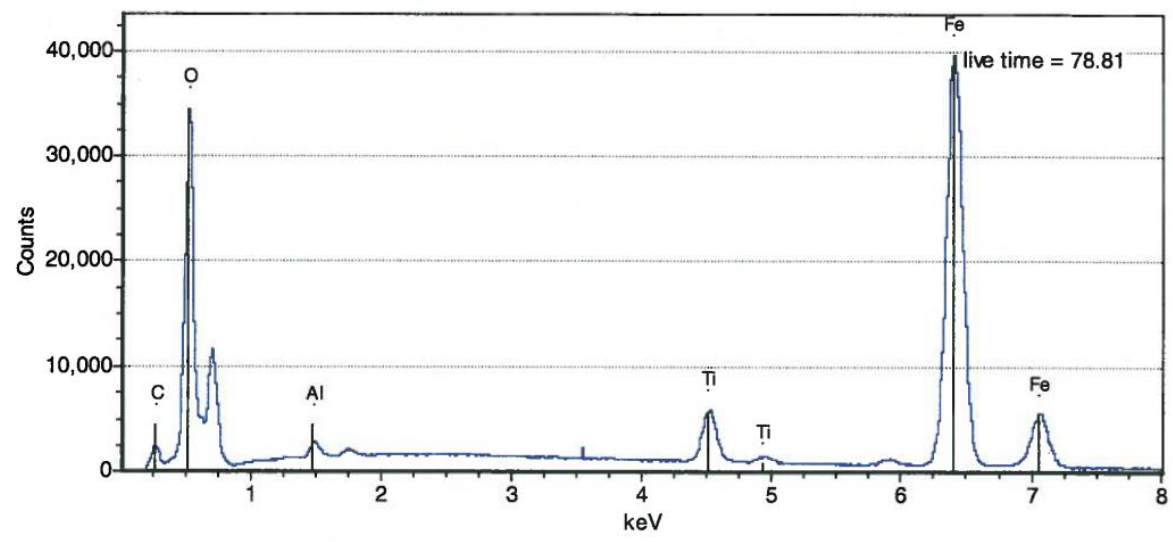


Andesite (sample S12-6A)

\section{USGS CVO ASPEX EXpress}

C:IDocuments and Settings\All Users IDocumentsVASPEXLizITygh Valley SamplesIS12_6A_3.TFF

$12 / 27 / 2013$

01:22:11 PN

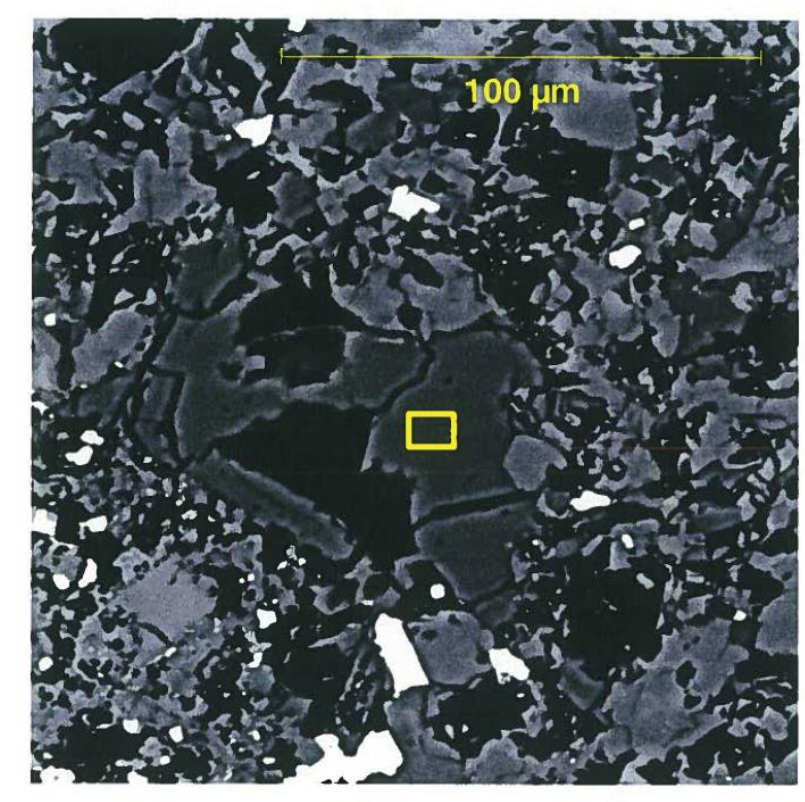

accelerating voltage $=20.0 \mathrm{kV}$

working distance $=17.6 \mathrm{~mm}$

spot size $=38.1 \%$

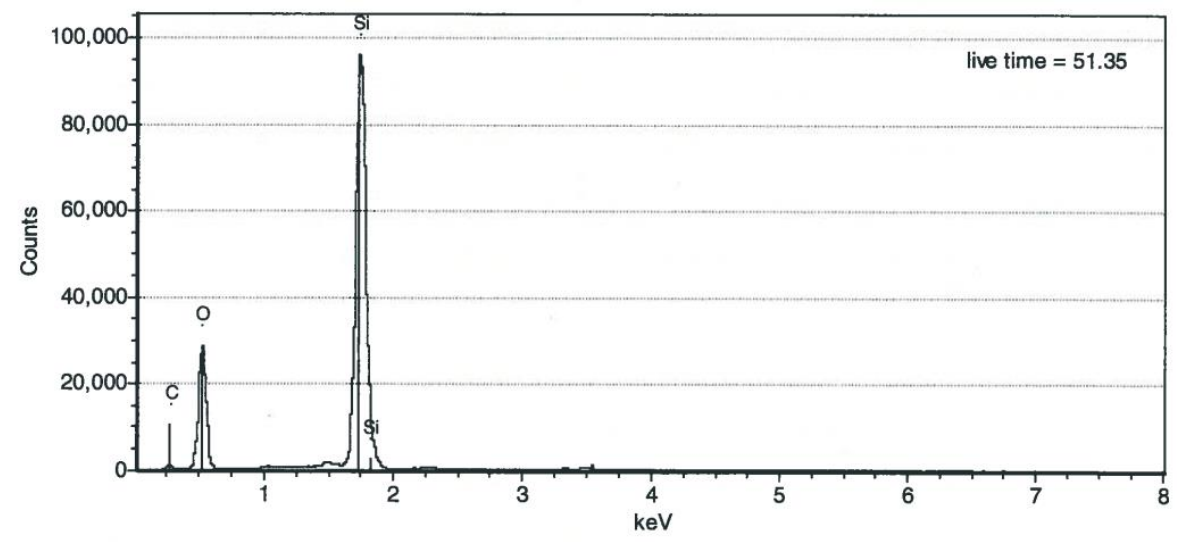




\section{Appendix D. Geochemical Data}

Table 3. Whole-rock geochemical analyses of rocks from Graveyard Butte's western and central canyon.

\begin{tabular}{|c|c|c|c|c|c|c|c|c|c|c|c|}
\hline \multirow{2}{*}{$\begin{array}{l}\text { Area } \\
\text { Sample }\end{array}$} & \multicolumn{5}{|c|}{ Graveyard Butte Western Canyon } & \multicolumn{6}{|c|}{ Graveyard Butte Central Canyon } \\
\hline & $\mathrm{CC} 3$ & CC6 & $\mathrm{CC} 7$ & $\mathrm{CC} 16$ & WR11 & S12-1L & S12-2 & S12-3 & S12-5 & S12-6 & WR13 \\
\hline Latitude & 45.1591 & 45.1555 & 45.1551 & 45.1646 & 45.1513 & 45.1576 & 45.1579 & 45.1580 & 45.1561 & 45.1561 & 45.1560 \\
\hline Longitude & -121.3157 & -121.3195 & -121.3194 & -121.3051 & -121.3231 & -121.3118 & -121.3119 & -121.3118 & -121.3135 & -121.3135 & -121.3160 \\
\hline Age (Ma) & & & & & & & & & & $3.86 \pm 0.07$ & \\
\hline \multicolumn{12}{|c|}{ Normalized Major Elements (Weight \%) } \\
\hline $\mathrm{SiO}_{2}$ & 72.61 & 49.51 & 72.97 & 56.98 & 50.17 & 72.93 & 72.83 & 62.61 & 61.29 & 62.17 & 73.17 \\
\hline $\mathrm{TiO}_{2}$ & 0.267 & 1.507 & 0.238 & 1.232 & 1.395 & 0.240 & 0.278 & 1.271 & 1.290 & 1.292 & 0.242 \\
\hline $\mathrm{Al}_{2} \mathrm{O}_{3}$ & 13.72 & 16.96 & 13.63 & 18.59 & 17.78 & 13.63 & 13.68 & 15.91 & 15.96 & 16.08 & 13.77 \\
\hline $\mathrm{FeO} *$ & 3.12 & 11.21 & 2.95 & 6.80 & 10.01 & 2.88 & 3.02 & 6.66 & 6.95 & 6.88 & 2.83 \\
\hline $\mathrm{MnO}$ & 0.089 & 0.175 & 0.084 & 0.131 & 0.166 & 0.077 & 0.092 & 0.155 & 0.134 & 0.123 & 0.083 \\
\hline $\mathrm{MgO}$ & 0.15 & 7.23 & 0.10 & 3.17 & 6.74 & 0.10 & 0.21 & 1.45 & 2.15 & 1.52 & 0.09 \\
\hline $\mathrm{CaO}$ & 0.99 & 9.81 & 0.98 & 7.09 & 9.53 & 0.92 & 0.84 & 4.65 & 5.07 & 4.81 & 0.63 \\
\hline $\mathrm{Na}_{2} \mathrm{O}$ & 5.17 & 3.06 & 5.03 & 4.13 & 3.29 & 5.37 & 5.28 & 4.82 & 4.77 & 4.68 & 5.38 \\
\hline $\mathrm{K}_{2} \mathrm{O}$ & 3.84 & 0.37 & 3.99 & 1.55 & 0.64 & 3.77 & 3.72 & 2.09 & 2.02 & 2.08 & 3.78 \\
\hline $\mathrm{P}_{2} \mathrm{O}_{5}$ & 0.037 & 0.176 & 0.029 & 0.329 & 0.266 & 0.092 & 0.053 & 0.376 & 0.367 & 0.359 & 0.035 \\
\hline $\begin{array}{l}\text { Pre- } \\
\text { normalized }\end{array}$ & 99.03 & 99.77 & 97.76 & 99.34 & 100.35 & 98.91 & 99.14 & 97.62 & 99.36 & 98.15 & 99.00 \\
\hline Normalized & 100.00 & 100.00 & 100.00 & 100.00 & 100.00 & 100.00 & 100.00 & 100.00 & 100.00 & 100.00 & 100.00 \\
\hline \multicolumn{12}{|l|}{ XRF (ppm) } \\
\hline $\mathrm{Ni}$ & 3 & 128 & 0 & 34 & 75 & 0 & 1 & 5 & 4 & 6 & 3 \\
\hline $\mathrm{Cr}$ & 3 & 228 & 2 & 30 & 127 & 3 & 2 & 1 & 1 & 1 & 2 \\
\hline $\mathrm{Sc}$ & 7 & 27 & 6 & 16 & 28 & 6 & 7 & 15 & 17 & 16 & 6 \\
\hline V & 8 & 202 & 5 & 152 & 166 & 3 & 13 & 99 & 103 & 127 & 7 \\
\hline $\mathrm{Ba}$ & 705 & 106 & 701 & 463 & 191 & 706 & 712 & 595 & 465 & 486 & 724 \\
\hline $\mathrm{Rb}$ & 90 & 5 & 88 & 21 & 7 & 86 & 82 & 41 & 41 & 38 & 85 \\
\hline
\end{tabular}


Table 3. Whole-rock geochemical analyses of rocks from Graveyard Butte's western and central canyon.

\begin{tabular}{|c|c|c|c|c|c|c|c|c|c|c|c|}
\hline \multirow{2}{*}{$\begin{array}{l}\text { Area } \\
\text { Sample }\end{array}$} & \multicolumn{5}{|c|}{ Graveyard Butte Western Canyon } & \multicolumn{6}{|c|}{ Graveyard Butte Central Canyon } \\
\hline & $\mathrm{CC} 3$ & CC6 & $\mathrm{CC} 7$ & $\mathrm{CC} 16$ & WR11 & S12-1L & S12-2 & S12-3 & S12-5 & S12-6 & WR13 \\
\hline $\mathrm{Sr}$ & 78 & 306 & 72 & 866 & 524 & 78 & 93 & 484 & 481 & 477 & 75 \\
\hline $\mathrm{Zr}$ & 495 & 92 & 491 & 181 & 141 & 490 & 486 & 282 & 283 & 285 & 491 \\
\hline $\mathrm{Y}$ & 54 & 24 & 56 & 22 & 27 & 47 & 51 & 50 & 43 & 40 & 49 \\
\hline $\mathrm{Nb}$ & 32.8 & 7.3 & 32.2 & 11.3 & 9.7 & 32.8 & 32.2 & 20.3 & 20.1 & 19.9 & 32.5 \\
\hline $\mathrm{Ga}$ & 23 & 19 & 22 & 21 & 19 & 23 & 23 & 22 & 23 & 21 & 23 \\
\hline $\mathrm{Cu}$ & 8 & 58 & 5 & 49 & 37 & 6 & 9 & 22 & 26 & 65 & 7 \\
\hline $\mathrm{Zn}$ & 110 & 98 & 104 & 77 & 87 & 99 & 104 & 100 & 103 & 145 & 104 \\
\hline $\mathrm{Pb}$ & 20 & 1 & 13 & 5 & 4 & 12 & 9 & 6 & 8 & 7 & 6 \\
\hline $\mathrm{La}$ & 47 & 7 & 43 & 27 & 11 & 32 & 41 & 43 & 36 & 33 & 46 \\
\hline $\mathrm{Ce}$ & 88 & 18 & 92 & 60 & 31 & 79 & 83 & 69 & 64 & 67 & 89 \\
\hline Th & 11 & 1 & 11 & 4 & 1 & 10 & 11 & 7 & 6 & 6 & 11 \\
\hline $\mathrm{Nd}$ & 44 & 12 & 45 & 30 & 19 & 35 & 44 & 43 & 43 & 39 & 43 \\
\hline $\mathrm{U}$ & 4 & 0 & 4 & 1 & 1 & 3 & 3 & 1 & 1 & 1 & 3 \\
\hline \multicolumn{12}{|c|}{ ICP-MS (ppm) } \\
\hline $\mathrm{La}$ & 44.68 & 7.22 & 44.59 & 26.63 & 13.68 & 34.34 & 43.92 & 40.64 & 35.83 & 34.22 & \\
\hline $\mathrm{Ce}$ & 92.38 & 16.36 & 92.77 & 57.31 & 31.60 & 80.05 & 86.53 & 66.66 & 64.58 & 63.85 & \\
\hline $\operatorname{Pr}$ & 11.56 & 2.47 & 11.38 & 7.59 & 4.33 & 9.02 & 11.10 & 9.77 & 10.06 & 9.52 & \\
\hline $\mathrm{Nd}$ & 45.21 & 11.80 & 44.58 & 30.82 & 18.97 & 35.36 & 43.58 & 41.02 & 42.21 & 39.40 & \\
\hline $\mathrm{Sm}$ & 10.35 & 3.50 & 10.28 & 6.04 & 4.48 & 8.34 & 9.91 & 9.00 & 9.80 & 8.96 & \\
\hline $\mathrm{Eu}$ & 1.79 & 1.33 & 1.72 & 1.80 & 1.60 & 1.75 & 1.83 & 2.42 & 2.55 & 2.48 & \\
\hline $\mathrm{Gd}$ & 9.78 & 4.19 & 9.82 & 5.23 & 4.78 & 7.98 & 9.33 & 9.45 & 9.27 & 8.80 & \\
\hline $\mathrm{Tb}$ & 1.68 & 0.71 & 1.67 & 0.78 & 0.80 & 1.38 & 1.55 & 1.45 & 1.45 & 1.32 & \\
\hline Dy & 10.21 & 4.56 & 10.21 & 4.34 & 5.04 & 8.67 & 9.50 & 8.55 & 8.53 & 7.78 & \\
\hline Ho & 2.07 & 0.91 & 2.05 & 0.82 & 1.04 & 1.75 & 1.89 & 1.71 & 1.64 & 1.51 & \\
\hline $\mathrm{Er}$ & 5.54 & 2.47 & 5.66 & 2.15 & 2.75 & 4.80 & 5.17 & 4.52 & 4.27 & 3.98 & \\
\hline $\mathrm{Tm}$ & 0.80 & 0.34 & 0.83 & 0.29 & 0.40 & 0.71 & 0.74 & 0.63 & 0.60 & 0.56 & \\
\hline
\end{tabular}


Table 3. Whole-rock geochemical analyses of rocks from Graveyard Butte's western and central canyon.

\begin{tabular}{|c|c|c|c|c|c|c|c|c|c|c|c|}
\hline \multirow{2}{*}{$\begin{array}{l}\text { Area } \\
\text { Sample }\end{array}$} & \multicolumn{5}{|c|}{ Graveyard Butte Western Canyon } & \multicolumn{6}{|c|}{ Graveyard Butte Central Canyon } \\
\hline & $\mathrm{CC} 3$ & CC6 & $\mathrm{CC} 7$ & CC16 & WR11 & S12-1L & S12-2 & S12-3 & S12-5 & S12-6 & WR13 \\
\hline $\mathrm{Yb}$ & 5.15 & 2.08 & 5.18 & 1.81 & 2.44 & 4.50 & 4.64 & 3.73 & 3.70 & 3.33 & \\
\hline $\mathrm{Lu}$ & 0.78 & 0.33 & 0.81 & 0.28 & 0.38 & 0.69 & 0.72 & 0.58 & 0.55 & 0.51 & \\
\hline $\mathrm{Ba}$ & 711 & 100 & 708 & 453 & 188 & 721 & 718 & 585 & 462 & 480 & \\
\hline Th & 11.17 & 0.64 & 10.90 & 3.95 & 1.42 & 10.94 & 10.69 & 5.86 & 5.93 & 5.97 & \\
\hline $\mathrm{Nb}$ & 31.82 & 5.93 & 31.03 & 9.74 & 8.06 & 31.49 & 30.85 & 18.49 & 18.36 & 18.70 & \\
\hline Y & 52.06 & 23.33 & 53.28 & 21.46 & 25.67 & 44.89 & 49.06 & 49.12 & 42.59 & 39.19 & \\
\hline $\mathrm{Hf}$ & 12.77 & 2.36 & 12.46 & 4.48 & 3.32 & 12.50 & 12.21 & 6.82 & 6.95 & 7.00 & \\
\hline $\mathrm{Ta}$ & 2.17 & 0.38 & 2.13 & 0.65 & 0.51 & 2.14 & 2.08 & 1.22 & 1.22 & 1.25 & \\
\hline $\mathrm{U}$ & 3.13 & 0.26 & 3.27 & 1.15 & 0.43 & 3.25 & 2.67 & 1.80 & 1.73 & 1.75 & \\
\hline $\mathrm{Pb}$ & 18.35 & 0.86 & 11.34 & 4.98 & 2.60 & 11.62 & 9.08 & 5.41 & 9.15 & 6.24 & \\
\hline $\mathrm{Rb}$ & 87.3 & 4.3 & 85.6 & 19.5 & 6.5 & 85.5 & 81.8 & 40.1 & 39.5 & 38.2 & \\
\hline Cs & 2.43 & 0.12 & 2.98 & 0.24 & 0.11 & 2.66 & 1.21 & 0.90 & 1.17 & 0.71 & \\
\hline $\mathrm{Sr}$ & 81 & 308 & 72 & 852 & 528 & 79 & 94 & 481 & 479 & 476 & \\
\hline $\mathrm{Sc}$ & 6.3 & 27.6 & 5.7 & 15.3 & 28.1 & 5.9 & 6.4 & 15.9 & 16.7 & 16.6 & \\
\hline $\mathrm{Zr}$ & 502 & 89 & 496 & 174 & 135 & 496 & 487 & 276 & 278 & 281 & \\
\hline
\end{tabular}


Table 4. Whole-rock geochemical analyses of rocks from Graveyard Butte quarry.

\begin{tabular}{|c|c|c|c|c|c|c|c|c|c|c|}
\hline \multirow{2}{*}{$\begin{array}{l}\text { Area } \\
\text { Sample }\end{array}$} & \multicolumn{10}{|c|}{ Quarry } \\
\hline & S6-9 & S6-10U & S6-11 & S6-12 & S6-13 & S6-15 & V1 & $\mathrm{X} 3$ & $\mathrm{X} 7 \mathrm{~b}$ & $X-9$ \\
\hline Latitude & 45.1624 & 45.1623 & 45.1627 & 45.1614 & 45.1625 & 45.1623 & 45.1623 & 45.1624 & 45.1624 & 45.1624 \\
\hline Longitude & -121.313 & -121.3154 & -121.3142 & -121.3143 & -121.3119 & -121.3137 & -121.3137 & -121.3134 & -121.3134 & -121.3133 \\
\hline Age (Ma) & & & & & & & & $3.67 \pm 0.01$ & & \\
\hline \multicolumn{11}{|c|}{ Normalized Major Elements (Weight \%) } \\
\hline $\mathrm{SiO}_{2}$ & 60.18 & 59.55 & 62.34 & 73.10 & 73.19 & 61.08 & 61.71 & 72.98 & 62.47 & 54.11 \\
\hline $\mathrm{TiO}_{2}$ & 1.386 & 0.857 & 1.203 & 0.241 & 0.243 & 1.303 & 1.255 & 0.238 & 1.221 & 1.365 \\
\hline $\mathrm{Al}_{2} \mathrm{O}_{3}$ & 16.07 & 18.57 & 15.78 & 13.64 & 13.59 & 15.88 & 15.79 & 13.60 & 15.86 & 18.33 \\
\hline $\mathrm{FeO}^{*}$ & 7.58 & 5.78 & 6.60 & 2.89 & 2.90 & 7.19 & 6.80 & 2.86 & 6.68 & 8.88 \\
\hline $\mathrm{MnO}$ & 0.137 & 0.096 & 0.134 & 0.082 & 0.080 & 0.134 & 0.134 & 0.084 & 0.125 & 0.144 \\
\hline $\mathrm{MgO}$ & 2.40 & 3.39 & 1.86 & 0.11 & 0.16 & 2.29 & 2.12 & 0.08 & 1.73 & 4.87 \\
\hline $\mathrm{CaO}$ & 5.64 & 6.51 & 4.66 & 0.79 & 0.79 & 5.28 & 4.97 & 1.02 & 4.64 & 8.01 \\
\hline $\mathrm{Na}_{2} \mathrm{O}$ & 4.47 & 4.05 & 4.82 & 5.30 & 5.27 & 4.45 & 4.79 & 5.36 & 4.65 & 3.13 \\
\hline $\mathrm{K}_{2} \mathrm{O}$ & 1.78 & 1.06 & 2.21 & 3.81 & 3.75 & 2.04 & 2.08 & 3.76 & 2.27 & 0.86 \\
\hline $\mathrm{P}_{2} \mathrm{O}_{5}$ & 0.347 & 0.148 & 0.386 & 0.042 & 0.031 & 0.347 & 0.360 & 0.032 & 0.350 & 0.296 \\
\hline $\begin{array}{l}\text { Pre- } \\
\text { normalized }\end{array}$ & 99.50 & 99.63 & 99.21 & 98.86 & 98.82 & 98.29 & 99.97 & 99.31 & 99.32 & 97.61 \\
\hline Normalized & 100.00 & 100.00 & 100.00 & 100.00 & 100.00 & 100.00 & 100.00 & 100.00 & 100.00 & 100.00 \\
\hline \multicolumn{11}{|l|}{ XRF (ppm) } \\
\hline $\mathrm{Ni}$ & 10 & 33 & 3 & 2 & 9 & 6 & 5 & 2 & 6 & 71 \\
\hline $\mathrm{Cr}$ & 7 & 26 & 2 & 2 & 2 & 3 & 0 & 3 & 1 & 103 \\
\hline $\mathrm{Sc}$ & 19 & 16 & 16 & 6 & 7 & 16 & 17 & 6 & 16 & 22 \\
\hline $\mathrm{V}$ & 117 & 129 & 75 & 10 & 38 & 123 & 108 & 4 & 133 & 152 \\
\hline $\mathrm{Ba}$ & 439 & 243 & 514 & 727 & 720 & 450 & 477 & 717 & 523 & 378 \\
\hline $\mathrm{Rb}$ & 37 & 15 & 43 & 86 & 84 & 42 & 44 & 86 & 54 & 13 \\
\hline
\end{tabular}


Table 4. Whole-rock geochemical analyses of rocks from Graveyard Butte quarry.

\begin{tabular}{|c|c|c|c|c|c|c|c|c|c|c|}
\hline \multirow{2}{*}{$\begin{array}{l}\text { Area } \\
\text { Sample }\end{array}$} & \multicolumn{10}{|c|}{ "Quarry } \\
\hline & S6-9 & S6-10U & S6-11 & S6-12 & S6-13 & S6-15 & V1 & $\mathrm{X} 3$ & $\mathrm{X} 7 \mathrm{~b}$ & $X-9$ \\
\hline $\mathrm{Sr}$ & 487 & 609 & 451 & 77 & 77 & 474 & 476 & 75 & 456 & 702 \\
\hline $\mathrm{Zr}$ & 261 & 120 & 302 & 491 & 489 & 276 & 293 & 490 & 301 & 176 \\
\hline Y & 35 & 14 & 40 & 54 & 57 & 35 & 37 & 52 & 54 & 24 \\
\hline $\mathrm{Nb}$ & 17.9 & 6.5 & 20.9 & 32.1 & 32.0 & 19.2 & 20.6 & 32.3 & 20.2 & 11.6 \\
\hline $\mathrm{Ga}$ & 22 & 21 & 21 & 24 & 24 & 21 & 23 & 24 & 21 & 20 \\
\hline $\mathrm{Cu}$ & 37 & 55 & 21 & 8 & 27 & 21 & 23 & 6 & 49 & 48 \\
\hline $\mathrm{Zn}$ & 103 & 63 & 94 & 103 & 95 & 99 & 101 & 95 & 103 & 90 \\
\hline $\mathrm{Pb}$ & 9 & 4 & 7 & 11 & 11 & 7 & 7 & 9 & 6 & 5 \\
\hline $\mathrm{La}$ & 28 & 11 & 32 & 50 & 42 & 29 & 33 & 48 & 36 & 19 \\
\hline $\mathrm{Ce}$ & 63 & 28 & 68 & 90 & 90 & 63 & 65 & 90 & 63 & 50 \\
\hline Th & 6 & 3 & 8 & 11 & 10 & 6 & 7 & 12 & 6 & 3 \\
\hline $\mathrm{Nd}$ & 32 & 16 & 37 & 49 & 41 & 33 & 34 & 44 & 42 & 26 \\
\hline $\mathrm{U}$ & 1 & 1 & 2 & 3 & 3 & 1 & 2 & 3 & 1 & 0 \\
\hline \multicolumn{11}{|c|}{ ICP-MS (ppm) } \\
\hline $\mathrm{La}$ & 28.34 & 12.29 & 32.78 & 49.66 & 43.63 & 29.47 & 31.30 & 45.94 & & \\
\hline $\mathrm{Ce}$ & 59.80 & 25.36 & 68.49 & 92.60 & 93.31 & 62.63 & 66.47 & 92.69 & & \\
\hline $\operatorname{Pr}$ & 7.71 & 3.52 & 9.00 & 12.57 & 10.97 & 8.06 & 8.52 & 11.63 & & \\
\hline $\mathrm{Nd}$ & 31.97 & 14.52 & 37.07 & 48.96 & 43.07 & 33.03 & 34.91 & 45.44 & & \\
\hline $\mathrm{Sm}$ & 7.21 & 3.34 & 8.58 & 11.12 & 9.88 & 7.50 & 7.94 & 10.12 & & \\
\hline $\mathrm{Eu}$ & 2.05 & 1.14 & 2.27 & 1.88 & 1.83 & 2.07 & 2.16 & 1.85 & & \\
\hline Gd & 7.18 & 3.18 & 8.20 & 10.16 & 9.57 & 7.24 & 7.54 & 9.59 & & \\
\hline $\mathrm{Tb}$ & 1.13 & 0.49 & 1.31 & 1.71 & 1.67 & 1.16 & 1.23 & 1.65 & & \\
\hline Dy & 6.81 & 2.75 & 7.77 & 10.26 & 10.31 & 6.81 & 7.12 & 9.89 & & \\
\hline Ho & 1.33 & 0.53 & 1.53 & 2.06 & 2.08 & 1.33 & 1.41 & 1.96 & & \\
\hline $\mathrm{Er}$ & 3.53 & 1.41 & 4.07 & 5.50 & 5.64 & 3.54 & 3.75 & 5.31 & & \\
\hline $\mathrm{Tm}$ & 0.49 & 0.19 & 0.58 & 0.79 & 0.83 & 0.50 & 0.53 & 0.78 & & \\
\hline
\end{tabular}


Table 4. Whole-rock geochemical analyses of rocks from Graveyard Butte quarry.

\begin{tabular}{|c|c|c|c|c|c|c|c|c|c|c|}
\hline \multirow{2}{*}{$\begin{array}{l}\text { Area } \\
\text { Sample }\end{array}$} & \multicolumn{10}{|c|}{ Quarry } \\
\hline & S6-9 & S6-10U & S6-11 & S6-12 & S6-13 & S6-15 & V1 & X3 & $X 7 b$ & X-9 \\
\hline $\mathrm{Yb}$ & 3.00 & 1.19 & 3.55 & 4.97 & 5.17 & 3.12 & 3.21 & 4.89 & & \\
\hline $\mathrm{Lu}$ & 0.47 & 0.18 & 0.55 & 0.74 & 0.79 & 0.48 & 0.49 & 0.77 & & \\
\hline $\mathrm{Ba}$ & 434 & 237 & 512 & 738 & 733 & 447 & 477 & 729 & & \\
\hline Th & 5.42 & 2.21 & 6.38 & 11.01 & 11.00 & 5.71 & 6.08 & 11.03 & & \\
\hline $\mathrm{Nb}$ & 16.62 & 5.42 & 19.74 & 31.21 & 31.37 & 17.95 & 19.11 & 31.72 & & \\
\hline $\mathrm{Y}$ & 34.19 & 13.31 & 38.96 & 52.24 & 53.85 & 34.55 & 35.97 & 51.08 & & \\
\hline $\mathrm{Hf}$ & 6.39 & 3.05 & 7.41 & 12.39 & 12.42 & 6.75 & 7.20 & 12.38 & & \\
\hline $\mathrm{Ta}$ & 1.11 & 0.38 & 1.31 & 2.11 & 2.13 & 1.21 & 1.30 & 2.13 & & \\
\hline $\mathrm{U}$ & 1.55 & 0.71 & 1.81 & 3.40 & 2.91 & 1.68 & 1.81 & 2.85 & & \\
\hline $\mathrm{Pb}$ & 8.22 & 4.23 & 6.88 & 10.33 & 9.39 & 6.04 & 6.43 & 8.08 & & \\
\hline $\mathrm{Rb}$ & 35.4 & 13.7 & 41.6 & 85.9 & 84.1 & 40.5 & 43.3 & 86.7 & & \\
\hline Cs & 1.17 & 0.24 & 0.78 & 2.55 & 1.20 & 1.33 & 1.40 & 1.76 & & \\
\hline $\mathrm{Sr}$ & 486 & 606 & 449 & 79 & 80 & 473 & 479 & 79 & & \\
\hline $\mathrm{Sc}$ & 19.2 & 14.7 & 15.8 & 6.1 & 6.2 & 16.9 & 16.0 & 5.9 & & \\
\hline $\mathrm{Zr}$ & 255 & 116 & 298 & 493 & 491 & 268 & 287 & 499 & & \\
\hline
\end{tabular}


Table 5. Whole-rock geochemical analyses of rocks from Graveyard Butte quarry and Eastern Canyon.

\begin{tabular}{|c|c|c|c|c|c|c|c|c|c|c|c|}
\hline \multirow{2}{*}{$\begin{array}{l}\text { Area } \\
\text { Sample }\end{array}$} & \multicolumn{8}{|c|}{ Quarry } & \multicolumn{3}{|c|}{ Eastern Canyon } \\
\hline & STR11-2a & STR11-2c & STR11-3 & STR11-4b & STR11-5 & STR11-6 & STR11-7 & STR11-8 & $\mathrm{CC} 13$ & $\mathrm{CC} 14$ & $\mathrm{CC} 15$ \\
\hline Latitude & 45.1624 & 45.1624 & 45.1624 & 45.1624 & 45.1624 & 45.1624 & 45.1624 & 45.1624 & 45.1684 & 45.1655 & 45.1692 \\
\hline Longitude & -121.3134 & -121.3134 & -121.3134 & -121.3134 & -121.3134 & -121.3134 & -121.3134 & -121.3134 & -121.2800 & -121.2843 & -121.2912 \\
\hline Age (Ma) & & & & & & & & & & $3.65 \pm 0.01$ & \\
\hline \multicolumn{12}{|c|}{ Normalized Major Elements (Weight \%): } \\
\hline $\mathrm{SiO}_{2}$ & 60.92 & 61.36 & 49.94 & 61.06 & 73.27 & 74.08 & 49.5 & 61.46 & 69.01 & 69.57 & 58.72 \\
\hline $\mathrm{TiO}_{2}$ & 1.31 & 1.283 & 1.504 & 1.311 & 0.245 & 0.256 & 1.457 & 1.32 & 0.636 & 0.561 & 1.495 \\
\hline $\mathrm{Al}_{2} \mathrm{O}_{3}$ & 15.82 & 15.84 & 17.44 & 15.87 & 13.59 & 13.9 & 18.43 & 16.39 & 14.64 & 14.34 & 16.24 \\
\hline $\mathrm{FeO}^{*}$ & 7.18 & 7.04 & 10.69 & 7.01 & 2.86 & 2.09 & 10.71 & 7.17 & 4.42 & 4.11 & 8.25 \\
\hline $\mathrm{MnO}$ & 0.135 & 0.133 & 0.175 & 0.136 & 0.082 & 0.054 & 0.175 & 0.142 & 0.077 & 0.095 & 0.144 \\
\hline $\mathrm{MgO}$ & 2.35 & 2.14 & 6.46 & 2.32 & 0.14 & 0.28 & 5.8 & 1.77 & 0.60 & 0.66 & 2.64 \\
\hline $\mathrm{CaO}$ & 5.39 & 5.13 & 9.7 & 5.3 & 0.74 & 1.33 & 10.11 & 4.63 & 2.13 & 2.12 & 5.99 \\
\hline $\mathrm{Na}_{2} \mathrm{O}$ & 4.55 & 4.67 & 3.26 & 4.66 & 5.27 & 4.15 & 3.11 & 4.7 & 5.15 & 5.16 & 4.44 \\
\hline $\mathrm{K}_{2} \mathrm{O}$ & 2 & 2.06 & 0.58 & 1.98 & 3.78 & 3.82 & 0.49 & 2.07 & 3.18 & 3.24 & 1.64 \\
\hline $\mathrm{P}_{2} \mathrm{O}_{5}$ & 0.346 & 0.351 & 0.236 & 0.356 & 0.034 & 0.043 & 0.222 & 0.354 & 0.169 & 0.143 & 0.425 \\
\hline $\begin{array}{l}\text { Pre- } \\
\text { normalized }\end{array}$ & 97.55 & 98.22 & 99.28 & 98.5 & 98.26 & 90.72 & 98.3 & 98.36 & 98.98 & 99.20 & 100.39 \\
\hline Normalized & 100.00 & 100.00 & 100.00 & 100.00 & 100.00 & 100.00 & 100.00 & 100.00 & 100.00 & 100.00 & 100.00 \\
\hline \multicolumn{12}{|l|}{ XRF (ppm) } \\
\hline $\mathrm{Ni}$ & 5 & 4 & 76 & 5 & 2 & 8 & 73 & 5 & 3 & 3 & 8 \\
\hline $\mathrm{Cr}$ & 2 & 1 & 124 & 0 & 3 & 3 & 126 & 2 & 3 & 2 & 3 \\
\hline $\mathrm{Sc}$ & 17 & 17 & 30 & 17 & 6 & 5 & 30 & 17 & 11 & 10 & 20 \\
\hline $\mathrm{V}$ & 126 & 113 & 194 & 123 & 12 & 5 & 194 & 68 & 41 & 34 & 118 \\
\hline $\mathrm{Ba}$ & 450 & 472 & 189 & 455 & 708 & 561 & 480 & 493 & 665 & 650 & 440 \\
\hline $\mathrm{Rb}$ & 41 & 42 & 6 & 42 & 84 & 57 & 4 & 41 & 72 & 70 & 34 \\
\hline $\mathrm{Sr}$ & 474 & 472 & 491 & 482 & 76 & 131 & 525 & 479 & 233 & 204 & 558 \\
\hline $\mathrm{Zr}$ & 269 & 280 & 129 & 272 & 487 & 235 & 122 & 284 & 424 & 432 & 236 \\
\hline
\end{tabular}


Table 5. Whole-rock geochemical analyses of rocks from Graveyard Butte quarry and Eastern Canyon.

\begin{tabular}{|c|c|c|c|c|c|c|c|c|c|c|c|}
\hline \multirow{2}{*}{$\begin{array}{l}\text { Area } \\
\text { Sample }\end{array}$} & \multicolumn{8}{|c|}{ Quarry } & \multicolumn{3}{|c|}{ Eastern Canyon } \\
\hline & STR11-2a & STR11-2c & STR11-3 & STR11-4b & STR11-5 & STR11-6 & STR11-7 & STR11-8 & $\mathrm{CC} 13$ & CC14 & $\mathrm{CC} 15$ \\
\hline $\mathrm{Y}$ & 35 & 37 & 27 & 34 & 56 & 19 & 27 & 38 & 48 & 50 & 32 \\
\hline $\mathrm{Nb}$ & 18.8 & 19.5 & 8.2 & 19.4 & 32.1 & 13.5 & 8.2 & 19.5 & 28.4 & 28.6 & 16.6 \\
\hline $\mathrm{Ga}$ & 21 & 21 & 20 & 21 & 22 & 16 & 20 & 22 & 22 & 22 & 22 \\
\hline $\mathrm{Cu}$ & 26 & 23 & 46 & 27 & 7 & 9 & 49 & 29 & 13 & 11 & 43 \\
\hline $\mathrm{Zn}$ & 98 & 95 & 86 & 100 & 101 & 42 & 86 & 96 & 101 & 87 & 98 \\
\hline $\mathrm{Pb}$ & 6 & 5 & 4 & 7 & 10 & 10 & 2 & 4 & 9 & 12 & 5 \\
\hline $\mathrm{La}$ & 31 & 34 & 11 & 32 & 45 & 23 & 13 & 32 & 43 & 38 & 26 \\
\hline $\mathrm{Ce}$ & 62 & 66 & 27 & 62 & 87 & 47 & 29 & 69 & 79 & 84 & 53 \\
\hline Th & 5 & 4 & 1 & 4 & 12 & 8 & 1 & 5 & 10 & 10 & 4 \\
\hline $\mathrm{Nd}$ & 33 & 37 & 17 & 34 & 43 & 19 & 19 & 35 & 44 & 42 & 31 \\
\hline $\mathrm{U}$ & 1 & 1 & 0 & 2 & 3 & 2 & 1 & 1 & 2 & 3 & 1 \\
\hline \multicolumn{12}{|c|}{ ICP-MS (ppm) } \\
\hline $\mathrm{La}$ & & & & & & & & & 42.52 & 41.05 & 26.12 \\
\hline $\mathrm{Ce}$ & & & & & & & & & 79.78 & 84.69 & 55.26 \\
\hline $\operatorname{Pr}$ & & & & & & & & & 11.28 & 10.57 & 7.31 \\
\hline $\mathrm{Nd}$ & & & & & & & & & 45.00 & 42.12 & 30.94 \\
\hline $\mathrm{Sm}$ & & & & & & & & & 10.14 & 9.60 & 7.13 \\
\hline $\mathrm{Eu}$ & & & & & & & & & 2.11 & 1.95 & 2.12 \\
\hline Gd & & & & & & & & & 9.38 & 9.28 & 6.84 \\
\hline $\mathrm{Tb}$ & & & & & & & & & 1.57 & 1.56 & 1.08 \\
\hline Dy & & & & & & & & & 9.20 & 9.35 & 6.25 \\
\hline Ho & & & & & & & & & 1.80 & 1.88 & 1.23 \\
\hline Er & & & & & & & & & 4.78 & 5.06 & 3.21 \\
\hline $\mathrm{Tm}$ & & & & & & & & & 0.68 & 0.73 & 0.44 \\
\hline $\mathrm{Yb}$ & & & & & & & & & 4.21 & 4.59 & 2.71 \\
\hline $\mathrm{Lu}$ & & & & & & & & & 0.64 & 0.71 & 0.43 \\
\hline
\end{tabular}


Table 5. Whole-rock geochemical analyses of rocks from Graveyard Butte quarry and Eastern Canyon.

\begin{tabular}{|c|c|c|c|c|c|c|c|c|c|c|c|}
\hline \multirow{2}{*}{$\begin{array}{l}\text { Area } \\
\text { Sample }\end{array}$} & \multicolumn{8}{|c|}{ Quarry } & \multicolumn{3}{|c|}{ Eastern Canyon } \\
\hline & STR11-2a & STR11-2c & STR11-3 & STR11-4b & STR11-5 & STR11-6 & STR11-7 & STR11-8 & $\mathrm{CC} 13$ & $\mathrm{CC} 14$ & $\mathrm{CC} 15$ \\
\hline $\mathrm{Ba}$ & & & & & & & & & 664 & 643 & 427 \\
\hline Th & & & & & & & & & 9.13 & 9.41 & 4.77 \\
\hline $\mathrm{Nb}$ & & & & & & & & & 27.00 & 27.68 & 15.48 \\
\hline $\mathrm{Y}$ & & & & & & & & & 45.99 & 48.37 & 31.07 \\
\hline Hf & & & & & & & & & 10.74 & 10.84 & 5.67 \\
\hline $\mathrm{Ta}$ & & & & & & & & & 1.81 & 1.87 & 1.03 \\
\hline $\mathrm{U}$ & & & & & & & & & 2.77 & 2.84 & 1.12 \\
\hline $\mathrm{Pb}$ & & & & & & & & & 8.52 & 10.98 & 4.43 \\
\hline $\mathrm{Rb}$ & & & & & & & & & 69.1 & 68.4 & 30.9 \\
\hline $\mathrm{Cs}$ & & & & & & & & & 1.19 & 0.66 & 0.54 \\
\hline $\mathrm{Sr}$ & & & & & & & & & 236 & 207 & 551 \\
\hline Sc & & & & & & & & & 9.9 & 9.0 & 19.8 \\
\hline $\mathrm{Zr}$ & & & & & & & & & 426 & 433 & 228 \\
\hline
\end{tabular}


Table 6. Whole rock geochemical analysis of rocks from Gordon Butte.

\begin{tabular}{|c|c|c|c|c|c|c|c|c|c|}
\hline \multirow{2}{*}{$\begin{array}{l}\text { Area } \\
\text { Sample }\end{array}$} & \multicolumn{9}{|c|}{ Gordon Butte } \\
\hline & GB1-3 & GB2 & GB3 & GB4-3 & GB5a & GB5b & GB6 & GB7 & GB10 \\
\hline Latitude & 45.2835 & 45.2983 & 45.2882 & 45.2697 & 45.2694 & 45.2694 & 45.2727 & 45.2701 & 45.2695 \\
\hline Longitude & -121.4063 & -121.4269 & -121.4098 & -121.4409 & -121.4416 & -121.4416 & -121.4371 & -121.4298 & -121.4410 \\
\hline Age (Ma) & & & & $3.64 \pm 0.03$ & & & & & \\
\hline \multicolumn{10}{|c|}{ Normalized Major Elements (Weight \%) } \\
\hline $\mathrm{SiO}_{2}$ & 71.49 & 70.05 & 71.79 & 72.14 & 71.26 & 69.97 & 70.12 & 69.60 & 72.04 \\
\hline $\mathrm{TiO}_{2}$ & 0.445 & 0.447 & 0.436 & 0.268 & 0.297 & 0.294 & 0.513 & 0.507 & 0.268 \\
\hline $\mathrm{Al}_{2} \mathrm{O}_{3}$ & 15.64 & 15.78 & 16.30 & 13.89 & 13.97 & 15.29 & 16.02 & 15.94 & 13.86 \\
\hline $\mathrm{FeO} *$ & 3.25 & 3.57 & 3.13 & 3.57 & 3.81 & 3.97 & 3.22 & 3.29 & 3.67 \\
\hline $\mathrm{MnO}$ & 0.050 & 0.091 & 0.052 & 0.091 & 0.097 & 0.106 & 0.039 & 0.047 & 0.103 \\
\hline $\mathrm{MgO}$ & 0.13 & 0.16 & 0.06 & 0.09 & 0.11 & 0.07 & 0.42 & 0.55 & 0.12 \\
\hline $\mathrm{CaO}$ & 1.20 & 1.61 & 0.79 & 0.64 & 1.13 & 1.11 & 1.55 & 1.88 & 0.68 \\
\hline $\mathrm{Na}_{2} \mathrm{O}$ & 4.28 & 5.11 & 3.77 & 5.66 & 5.09 & 4.79 & 4.03 & 4.13 & 5.63 \\
\hline $\mathrm{K}_{2} \mathrm{O}$ & 3.48 & 3.11 & 3.64 & 3.61 & 4.20 & 4.38 & 4.04 & 3.99 & 3.60 \\
\hline $\mathrm{P}_{2} \mathrm{O}_{5}$ & 0.040 & 0.077 & 0.019 & 0.032 & 0.033 & 0.028 & 0.057 & 0.082 & 0.026 \\
\hline $\begin{array}{l}\text { Pre- } \\
\text { normalized }\end{array}$ & 98.29 & 98.32 & 96.51 & 99.21 & 97.07 & 95.18 & 98.81 & 98.32 & 98.96 \\
\hline Normalized & 100.00 & 100.00 & 100.00 & 100.00 & 100.00 & 100.00 & 100.00 & 100.00 & 100.00 \\
\hline \multicolumn{10}{|l|}{ XRF (ppm) } \\
\hline $\mathrm{Ni}$ & 3 & 2 & 2 & 2 & 4 & 2 & 4 & 6 & 2 \\
\hline $\mathrm{Cr}$ & 3 & 4 & 3 & 2 & 3 & 4 & 5 & 6 & 2 \\
\hline $\mathrm{Sc}$ & 5 & 8 & 6 & 6 & 6 & 6 & 6 & 7 & 5 \\
\hline $\mathrm{V}$ & 20 & 18 & 16 & 3 & 4 & 2 & 32 & 28 & 5 \\
\hline $\mathrm{Ba}$ & 650 & 598 & 549 & 703 & 690 & 732 & 635 & 596 & 702 \\
\hline $\mathrm{Rb}$ & 78 & 71 & 82 & 78 & 79 & 72 & 102 & 98 & 77 \\
\hline $\mathrm{Sr}$ & 140 & 192 & 98 & 81 & 75 & 86 & 189 & 206 & 82 \\
\hline
\end{tabular}


Table 6. Whole rock geochemical analysis of rocks from Gordon Butte.

\begin{tabular}{|c|c|c|c|c|c|c|c|c|c|}
\hline \multirow{2}{*}{$\begin{array}{l}\text { Area } \\
\text { Sample }\end{array}$} & \multicolumn{9}{|c|}{ Gordon Butte } \\
\hline & GB1-3 & GB2 & GB3 & GB4-3 & GB5a & GB5b & GB6 & GB7 & GB10 \\
\hline $\mathrm{Zr}$ & 329 & 344 & 330 & 491 & 503 & 526 & 366 & 359 & 497 \\
\hline $\mathrm{Y}$ & 21 & 33 & 22 & 50 & 60 & 58 & 29 & 39 & 54 \\
\hline $\mathrm{Nb}$ & 18.0 & 20.8 & 18.4 & 39.6 & 39.4 & 41.3 & 17.4 & 16.9 & 39.7 \\
\hline $\mathrm{Ga}$ & 21 & 22 & 21 & 25 & 24 & 26 & 20 & 20 & 25 \\
\hline $\mathrm{Cu}$ & 12 & 10 & 10 & 2 & 4 & 3 & 7 & 12 & 3 \\
\hline $\mathrm{Zn}$ & 51 & 82 & 45 & 115 & 124 & 128 & 41 & 45 & 115 \\
\hline $\mathrm{Pb}$ & 9 & 11 & 8 & 7 & 11 & 11 & 10 & 10 & 6 \\
\hline $\mathrm{La}$ & 31 & 34 & 29 & 45 & 48 & 43 & 38 & 42 & 33 \\
\hline $\mathrm{Ce}$ & 54 & 70 & 67 & 89 & 95 & 93 & 70 & 64 & 80 \\
\hline Th & 11 & 10 & 12 & 10 & 10 & 11 & 14 & 14 & 9 \\
\hline $\mathrm{Nd}$ & 23 & 31 & 27 & 45 & 46 & 43 & 35 & 38 & 34 \\
\hline $\mathrm{U}$ & 3 & 2 & 5 & 3 & 3 & 2 & 6 & 5 & 3 \\
\hline \multicolumn{10}{|c|}{ ICP-MS (ppm) } \\
\hline $\mathrm{La}$ & 29.52 & 34.00 & 30.51 & 44.26 & 47.54 & 45.45 & 40.25 & 43.14 & \\
\hline $\mathrm{Ce}$ & 53.46 & 71.16 & 68.92 & 86.24 & 92.53 & 94.48 & 67.44 & 68.26 & \\
\hline $\operatorname{Pr}$ & 6.27 & 8.20 & 7.10 & 11.12 & 11.94 & 11.51 & 9.02 & 10.53 & \\
\hline $\mathrm{Nd}$ & 21.89 & 31.14 & 24.83 & 44.17 & 47.30 & 45.19 & 32.99 & 39.94 & \\
\hline $\mathrm{Sm}$ & 4.28 & 6.70 & 5.06 & 9.94 & 10.70 & 10.38 & 6.41 & 8.11 & \\
\hline $\mathrm{Eu}$ & 0.91 & 1.44 & 0.87 & 1.99 & 1.99 & 2.08 & 1.16 & 1.57 & \\
\hline Gd & 3.60 & 6.05 & 3.90 & 9.49 & 10.48 & 10.13 & 5.27 & 7.35 & \\
\hline $\mathrm{Tb}$ & 0.60 & 1.01 & 0.67 & 1.57 & 1.80 & 1.77 & 0.87 & 1.17 & \\
\hline Dy & 3.66 & 6.01 & 4.07 & 9.69 & 11.24 & 10.85 & 5.22 & 6.94 & \\
\hline Ho & 0.72 & 1.17 & 0.81 & 1.92 & 2.25 & 2.17 & 1.02 & 1.39 & \\
\hline $\mathrm{Er}$ & 2.01 & 3.21 & 2.28 & 5.18 & 6.17 & 6.01 & 2.85 & 3.79 & \\
\hline $\mathrm{Tm}$ & 0.30 & 0.47 & 0.35 & 0.75 & 0.90 & 0.88 & 0.42 & 0.55 & \\
\hline $\mathrm{Yb}$ & 2.05 & 3.00 & 2.36 & 4.81 & 5.55 & 5.45 & 2.69 & 3.45 & \\
\hline
\end{tabular}


Table 6. Whole rock geochemical analysis of rocks from Gordon Butte.

\begin{tabular}{|c|c|c|c|c|c|c|c|c|c|}
\hline \multirow{2}{*}{$\begin{array}{l}\text { Area } \\
\text { Sample }\end{array}$} & \multicolumn{9}{|c|}{ Gordon Butte } \\
\hline & GB1-3 & GB2 & GB3 & GB4-3 & GB5a & GB5b & GB6 & GB7 & GB10 \\
\hline $\mathrm{Lu}$ & 0.32 & 0.46 & 0.35 & 0.74 & 0.85 & 0.83 & 0.40 & 0.53 & \\
\hline $\mathrm{Ba}$ & 646 & 595 & 551 & 704 & 694 & 739 & 637 & 602 & \\
\hline Th & 11.36 & 9.27 & 11.68 & 9.91 & 10.02 & 10.06 & 13.41 & 12.91 & \\
\hline $\mathrm{Nb}$ & 16.97 & 19.02 & 17.37 & 38.39 & 38.94 & 40.01 & 16.98 & 16.43 & \\
\hline $\mathrm{Y}$ & 18.84 & 30.13 & 19.56 & 48.03 & 58.10 & 55.91 & 26.66 & 37.58 & \\
\hline $\mathrm{Hf}$ & 8.28 & 8.39 & 8.38 & 12.30 & 12.63 & 12.98 & 9.51 & 9.27 & \\
\hline $\mathrm{Ta}$ & 1.44 & 1.44 & 1.49 & 2.50 & 2.52 & 2.60 & 1.39 & 1.34 & \\
\hline $\mathrm{U}$ & 3.30 & 2.74 & 4.07 & 3.00 & 3.02 & 2.90 & 4.14 & 4.18 & \\
\hline $\mathrm{Pb}$ & 8.34 & 8.45 & 7.42 & 5.59 & 10.29 & 10.28 & 9.48 & 10.03 & \\
\hline $\mathrm{Rb}$ & 76.4 & 69.5 & 80.4 & 77.2 & 77.7 & 69.3 & 100.0 & 96.6 & \\
\hline Cs & 0.89 & 1.12 & 1.50 & 1.36 & 3.39 & 3.15 & 1.64 & 2.16 & \\
\hline $\mathrm{Sr}$ & 138 & 190 & 98 & 82 & 74 & 87 & 190 & 211 & \\
\hline $\mathrm{Sc}$ & 5.0 & 7.6 & 4.9 & 5.7 & 5.5 & 6.1 & 5.7 & 6.3 & \\
\hline $\mathrm{Zr}$ & 319 & 330 & 323 & 494 & 510 & 530 & 364 & 361 & \\
\hline
\end{tabular}


Table 7. Whole-rock geochemical analysis of Tygh Valley samples.

\begin{tabular}{|c|c|c|c|c|}
\hline \multirow{2}{*}{$\begin{array}{l}\text { Area } \\
\text { Sample }\end{array}$} & \multirow{2}{*}{$\begin{array}{l}\text { McCubbins } \\
\text { Gulch } \\
\text { WWR4 }\end{array}$} & \multirow{2}{*}{$\begin{array}{c}\text { Hootnanny } \\
\text { Point } \\
\text { H2 }\end{array}$} & \multicolumn{2}{|c|}{ Mill Creek Buttes } \\
\hline & & & MC1 & MC4 \\
\hline Latitude & 45.1465 & 45.3216 & 45.4447 & 45.4417 \\
\hline Longitude & -121.4286 & -121.3799 & -121.5220 & -121.5167 \\
\hline \multicolumn{5}{|c|}{ Normalized Major Elements (Weight \%): } \\
\hline $\mathrm{SiO}_{2}$ & 63.05 & 69.40 & 64.83 & 63.64 \\
\hline $\mathrm{TiO}_{2}$ & 0.822 & 0.492 & 0.652 & 0.698 \\
\hline $\mathrm{Al}_{2} \mathrm{O}_{3}$ & 17.10 & 15.61 & 17.40 & 17.14 \\
\hline $\mathrm{FeO} *$ & 5.32 & 3.64 & 4.03 & 4.57 \\
\hline $\mathrm{MnO}$ & 0.103 & 0.081 & 0.077 & 0.083 \\
\hline $\mathrm{MgO}$ & 2.32 & 0.47 & 2.08 & 2.84 \\
\hline $\mathrm{CaO}$ & 5.04 & 2.09 & 5.57 & 5.96 \\
\hline $\mathrm{Na}_{2} \mathrm{O}$ & 4.18 & 5.17 & 4.12 & 3.99 \\
\hline $\mathrm{K}_{2} \mathrm{O}$ & 1.88 & 2.94 & 1.09 & 0.94 \\
\hline $\mathrm{P}_{2} \mathrm{O}_{5}$ & 0.176 & 0.099 & 0.156 & 0.153 \\
\hline $\begin{array}{l}\text { Pre- } \\
\text { normalized }\end{array}$ & 99.24 & 98.87 & 99.08 & 98.96 \\
\hline Normalized & 100.00 & 100.00 & 100.00 & 100.00 \\
\hline \multicolumn{5}{|l|}{ XRF (ppm) } \\
\hline $\mathrm{Ni}$ & 25 & 4 & 22 & 38 \\
\hline $\mathrm{Cr}$ & 23 & 2 & 27 & 51 \\
\hline $\mathrm{Sc}$ & 12 & 8 & 9 & 13 \\
\hline V & 105 & 21 & 69 & 90 \\
\hline $\mathrm{Ba}$ & 408 & 556 & 242 & 226 \\
\hline $\mathrm{Rb}$ & 28 & 67 & 23 & 20 \\
\hline $\mathrm{Sr}$ & 564 & 243 & 770 & 778 \\
\hline $\mathrm{Zr}$ & 205 & 325 & 142 & 133 \\
\hline Y & 23 & 31 & 15 & 13 \\
\hline $\mathrm{Nb}$ & 10.3 & 18.7 & 6.9 & 6.5 \\
\hline $\mathrm{Ga}$ & 19 & 22 & 21 & 19 \\
\hline $\mathrm{Cu}$ & 37 & 12 & 28 & 32 \\
\hline $\mathrm{Zn}$ & 67 & 67 & 54 & 62 \\
\hline $\mathrm{Pb}$ & 6 & 9 & 4 & 4 \\
\hline $\mathrm{La}$ & 25 & 31 & 14 & 15 \\
\hline $\mathrm{Ce}$ & 40 & 67 & 26 & 30 \\
\hline Th & 4 & 8 & 4 & 3 \\
\hline $\mathrm{Nd}$ & 23 & 29 & 16 & 15 \\
\hline $\mathrm{U}$ & 1 & 3 & 0 & 1 \\
\hline
\end{tabular}


Table 7. Whole-rock geochemical analysis of Tygh Valley samples.

\begin{tabular}{|c|c|c|c|c|}
\hline \multirow{2}{*}{$\begin{array}{l}\text { Area } \\
\text { Sample }\end{array}$} & \multirow{2}{*}{$\begin{array}{l}\text { McCubbins } \\
\text { Gulch } \\
\text { WWR4 }\end{array}$} & \multirow{2}{*}{$\begin{array}{c}\text { Hootnanny } \\
\text { Point } \\
\text { H2 }\end{array}$} & \multicolumn{2}{|c|}{ Mill Creek Buttes } \\
\hline & & & $\mathrm{MC} 1$ & MC4 \\
\hline \multicolumn{5}{|c|}{ ICP-MS (ppm) } \\
\hline $\mathrm{La}$ & 22.02 & 32.35 & 14.29 & 13.83 \\
\hline $\mathrm{Ce}$ & 42.49 & 67.68 & 28.66 & 29.46 \\
\hline $\operatorname{Pr}$ & 6.02 & 7.61 & 3.85 & 3.75 \\
\hline $\mathrm{Nd}$ & 24.78 & 28.62 & 15.49 & 15.25 \\
\hline Sm & 5.40 & 6.12 & 3.47 & 3.33 \\
\hline $\mathrm{Eu}$ & 1.49 & 1.39 & 1.14 & 1.12 \\
\hline $\mathrm{Gd}$ & 4.82 & 5.60 & 3.12 & 2.98 \\
\hline $\mathrm{Tb}$ & 0.74 & 0.93 & 0.47 & 0.45 \\
\hline Dy & 4.25 & 5.69 & 2.66 & 2.55 \\
\hline Ho & 0.81 & 1.12 & 0.51 & 0.48 \\
\hline $\mathrm{Er}$ & 2.12 & 3.07 & 1.31 & 1.25 \\
\hline $\mathrm{Tm}$ & 0.30 & 0.46 & 0.19 & 0.17 \\
\hline $\mathrm{Yb}$ & 1.89 & 2.93 & 1.15 & 1.11 \\
\hline $\mathrm{Lu}$ & 0.29 & 0.45 & 0.18 & 0.16 \\
\hline $\mathrm{Ba}$ & 405 & 559 & 238 & 222 \\
\hline Th & 4.39 & 8.73 & 2.89 & 2.40 \\
\hline $\mathrm{Nb}$ & 9.60 & 17.90 & 6.04 & 5.84 \\
\hline Y & 21.86 & 29.25 & 13.25 & 11.95 \\
\hline $\mathrm{Hf}$ & 5.11 & 8.15 & 3.49 & 3.30 \\
\hline $\mathrm{Ta}$ & 0.72 & 1.34 & 0.46 & 0.44 \\
\hline $\mathrm{U}$ & 1.39 & 2.80 & 0.88 & 0.74 \\
\hline $\mathrm{Pb}$ & 5.88 & 7.58 & 3.44 & 3.07 \\
\hline $\mathrm{Rb}$ & 27.1 & 66.0 & 23.0 & 19.2 \\
\hline Cs & 0.34 & 1.08 & 0.78 & 0.45 \\
\hline $\mathrm{Sr}$ & 557 & 242 & 771 & 761 \\
\hline $\mathrm{Sc}$ & 11.4 & 7.9 & 9.0 & 11.5 \\
\hline $\mathrm{Zr}$ & 199 & 325 & 135 & 127 \\
\hline
\end{tabular}




\section{Appendix E. ${ }^{40} \mathrm{Ar} /{ }^{39} \mathrm{Ar}$ Age Results for Graveyard and Gordon Buttes}

Table 8. ${ }^{40} \mathrm{Ar} /{ }^{39} \mathrm{Ar}$ Age Results for Samples at Graveyard and Gordon Buttes.

\begin{tabular}{|c|c|c|c|c|c|c|c|c|c|c|c|c|}
\hline $\begin{array}{l}\text { Sampl } \\
\text { e No. }\end{array}$ & Latitude & Longitude & $\begin{array}{l}\text { Rock location / } \\
\text { type }\end{array}$ & $\begin{array}{l}\text { Material } \\
\text { Dated }\end{array}$ & Analysis & Steps & $\%^{39} \mathrm{Ar}$ & $\mathrm{K} / \mathrm{Ca}$ & $\begin{array}{l}\text { Age } \pm 2 \sigma \\
(\mathrm{Ma})\end{array}$ & Analy-sis & $\mathrm{K} / \mathrm{Ca}$ & $\begin{array}{l}\text { Age } \pm 2 \sigma \\
(\mathrm{Ma})\end{array}$ \\
\hline X3 & 45.1624 & -121.3134 & $\begin{array}{l}\text { Graveyard Butte / } \\
\text { rhyolite }\end{array}$ & $\begin{array}{l}\text { Ground- } \\
\text { mass }\end{array}$ & $\begin{array}{l}\text { Weighted } \\
\text { Plateau }\end{array}$ & 17 & 50.39 & 0.44 & $3.71 \pm 0.01$ & $\begin{array}{l}\text { Total } \\
\text { Fusion }\end{array}$ & 1.55 & $3.72 \pm 0.01$ \\
\hline X3 & 45.1624 & -121.3134 & $\begin{array}{l}\text { Graveyard Butte / } \\
\text { rhyolite }\end{array}$ & Feldspar & $\begin{array}{l}\text { Weighted } \\
\text { Plateau }\end{array}$ & 11 & 81.15 & 0.409 & $3.67 \pm 0.01$ & $\begin{array}{l}\text { Total } \\
\text { Fusion }\end{array}$ & 0.395 & $3.70 \pm 0.01$ \\
\hline CC14 & 45.1655 & -121.2843 & $\begin{array}{l}\text { Graveyard Butte / } \\
\text { rhyolite }\end{array}$ & Feldspar & $\begin{array}{l}\text { Weighted } \\
\text { Plateau }\end{array}$ & 12 & 92.28 & 0.324 & $3.65 \pm 0.01$ & $\begin{array}{l}\text { Total } \\
\text { Fusion }\end{array}$ & 0.328 & $3.65 \pm 0.01$ \\
\hline S12-6 & 45.1561 & -121.3135 & $\begin{array}{l}\text { Graveyard Butte / } \\
\text { andesite }\end{array}$ & $\begin{array}{l}\text { Ground- } \\
\text { mass }\end{array}$ & $\begin{array}{l}\text { Weighted } \\
\text { Plateau }\end{array}$ & 6 & 89.58 & 0.54 & $3.86 \pm 0.07$ & $\begin{array}{l}\text { Total } \\
\text { Fusion }\end{array}$ & 0.62 & $3.77 \pm 0.09$ \\
\hline GB4-3 & 45.2697 & -121.4410 & $\begin{array}{l}\text { Gordon Butte / } \\
\text { rhyolite }\end{array}$ & $\begin{array}{l}\text { Ground- } \\
\text { mass }\end{array}$ & $\begin{array}{l}\text { Weighted } \\
\text { Plateau }\end{array}$ & 27 & 66.56 & 0.30 & $3.70 \pm 0.01$ & $\begin{array}{l}\text { Total } \\
\text { Fusion }\end{array}$ & 1.78 & $3.72 \pm 0.01$ \\
\hline GB4-3 & 45.2697 & -121.4410 & $\begin{array}{l}\text { Gordon Butte / } \\
\text { rhyolite }\end{array}$ & Feldspar & $\begin{array}{l}\text { Weighted } \\
\text { Plateau }\end{array}$ & 18 & 100.00 & 0.302 & $3.64 \pm 0.03$ & $\begin{array}{l}\text { Total } \\
\text { Fusion }\end{array}$ & 0.312 & $3.64 \pm 0.04$ \\
\hline
\end{tabular}

